\author{
Universidade de Brasília \\ Instituto de Ciências Sociais \\ Departamento de Antropologia \\ Programa de Pós-Graduação em Antropologia Social
}

\title{
O Direito em Última Instância: Uma Etnografia do Supremo Tribunal Federal
}

Andressa Lewandowski 


\section{O Direito em Última Instância: Uma Etnografia do Supremo Tribunal Federal}

Tese de doutorado apresentada ao Programa de Pós-graduação em Antropologia Social da Universidade de Brasília para obtenção do título de Doutor em Antropologia

Orientadora: Profa. Dra. Antonádia Monteiro Borges Departamento de Antropologia da Universidade de Brasília 


\section{RESUMO}

A presente tese é uma etnografia das formas de produção jurídica no Supremo Tribunal Federal. Procurei rastrear essas produções a partir da invenção e circulação dos processos, das técnicas de decisão e dos espaços de intervenção dos ministros, assessores e analistas judiciários. Apresento então, uma análise das relações internas ao tribunal evidenciando os documentos e os processos de documentação, os procedimentos e as temporalidades nos fluxos dos processamentos de uma Ação Judicial. Através dos processamentos busca-se apreender a agência das formas legais e as relações entre pessoas, causas e processos a partir das rotinas de trabalho dos setores do tribunal que produzem e circulam os autos processuais. Busca-se, assim, refletir sobre as formas e as relações ativadas no curso dos processos, com vistas a estabelecer os caminhos de uma decisão. 


\begin{abstract}
This thesis is an ethnography of the law's production systems on the Brazilian Supreme Court. The idea is to trace these productions from its invention and files circulation, the decision techniques e the intervention spaces of the ministers, assessors and law analytics. I then analyze the court's internal relations, highlighting the documents and documentation process, the procedures and the temporality on the processing fluxes' of an action. Throughout the processing it seeks to capture the legal forms' agency and the relation between people, causes and process, from the court sections work routine where the files are produced and circulate. It seeks, this way, to reflect on the form and relations activated through the files' course, aiming to establish the ways for a decision.
\end{abstract}




\section{AGRADECIMENTOS}

Começo agradecendo à orientadora desta tese, Antonádia Monteiro Borges, por ter acreditado na pesquisa, pela paciência, pelos comentários precisos, pelas críticas ao longo de toda a trajetória de escrita da tese. Ainda que me responsabilize por qualquer impropriedade presente, devo o trabalho a ela.

Agradeço ao CNPQ pela bolsa de pesquisa durante os quatro anos do doutorado, assim como aos professores e servidores do Departamento de Antropologia, em especial a Rosa e Adriana.

Às professoras Ciméa Bevilacqua, Edilene Cofacci de Lima e Marcela Stockler Coelho de Souza, por quem nutro grande admiração e devo parte de minha formação.

Aos integrantes da banca Alexandre Nodari, Luís Roberto Cardoso de Oliveira, Ciméa Bevilacqua e Patrice Schuch, agradeço o aceite do convite e a disposição para leitura e diálogo.

Aos servidores do Supremo Tribunal Federal, pela generosidade, atenção e por terem me ensinado um pouco do que fazem.

Às amigas e grandes interlocutoras desde o mestrado: Aline Iubel, Nicole Soares Pinto e Dayana Zdebisky. Espero poder agradecê-las outras tantas vezes como garantia de que estaremos sempre perto ainda que longe.

À minha turma de doutorado: Julia Otero, Carolina Pedreira, Diogo Bonadiman, agradeço pelos debates em sala de aula, mas, sobretudo, pela convivência afetuosa e pelos momentos divertidos. À Gustavo Onto, amigo que dividiu comigo a descoberta de novos textos e novos caminhos para pensar as práticas dos tribunais.

À Olguinha, Ivan, Tati e Mariah. Obrigada pela acolhida, por me receber nessa família. 
À minha mãe, pelo incentivo constante, ainda que longe. Ao meu pai e aos meus irmãos, por me trazerem de volta pra terra em diversos momentos desta tese.

Termino agradecendo ao meu companheiro Giulio Pascoli. Ninguém mais do que ele sofreu com as agruras do processo de escrita. Agradeço pela paciência, pelo carinho, por ler o texto dezenas de vezes e por ser a pessoa que estava sempre lá, me esperando. 


\section{SUMÁRIO}

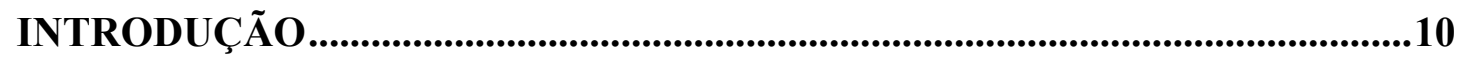

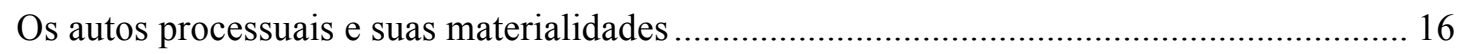

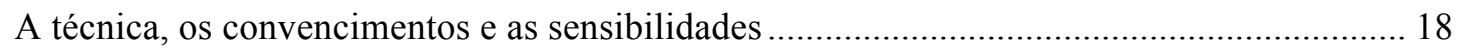

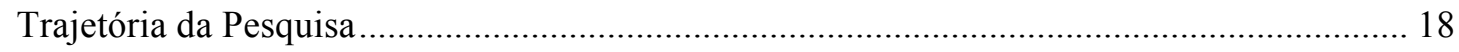

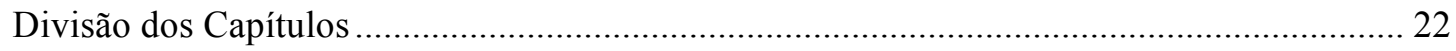

CAPÍTULO 1 - A Constituição Como Forma do Direito...........................................24

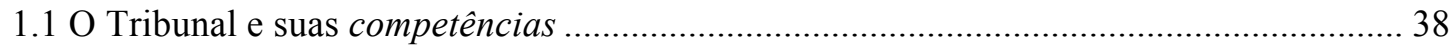

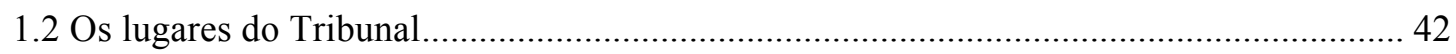

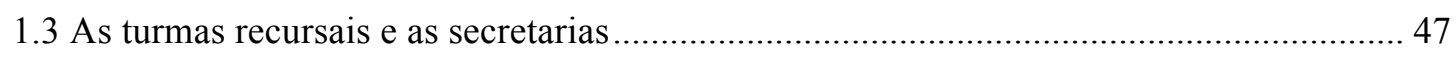

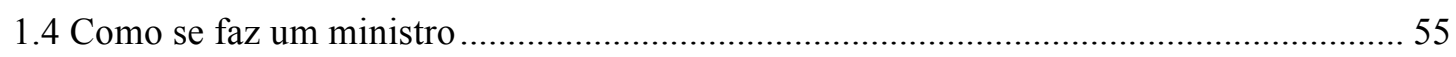

CAPÍTULO 2 - O Processo .................................................................................71

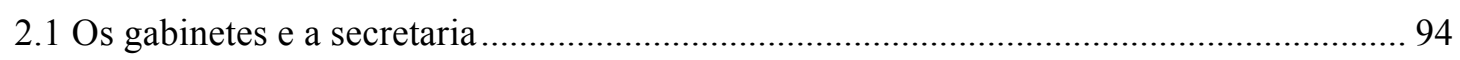

CAPÍTULO 3 - O Direito Como Técnica e a Técnica do Direito ..........................116

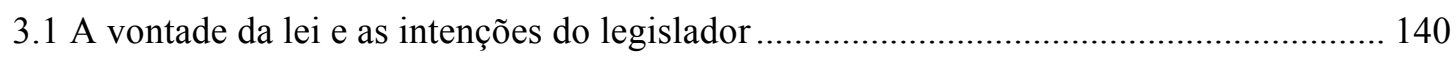

3.2 A política dos processos e as possibilidade de mudanças ................................................ 148

CAPÍTULO 4 - O Julgamento ...................................................................157

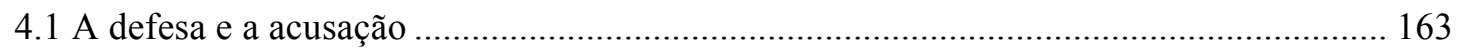

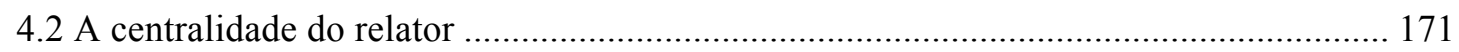

4.3 Os votos dos vogais e os convencimentos ............................................................... 177

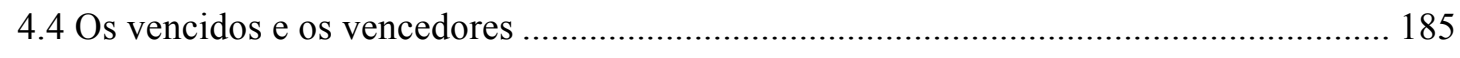

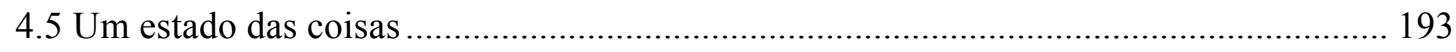

CONSIDERAÇÕES FINAIS ...........................................................................195

REFERÊNCIAS BIBLIOGRÁFICAS.............................................................200

ANEXO 1- Biografia dos Ministros .......................................................................209

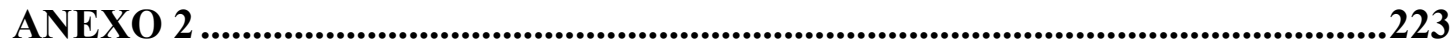

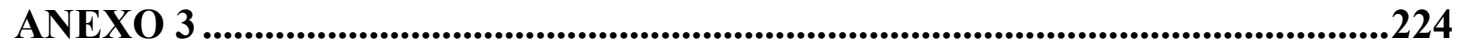




\section{LISTA DE SIGLAS E ABREVIAÇÕES}

$\mathrm{AC}$ - Ação Cautelar

ADC - Ação Declaratória de Constitucionalidade

ADCT - Atos de Disposições Constitucionais Transitórias

ADI - Ação Direta de Inconstitucionalidade

AGU - Advocacia-Geral da União

$\mathrm{AI}$ - Agravo de Instrumento

ANC- Assembleia Nacional Constituinte

aRE - Agravo em Recurso Extraordinário

CCJ - Comissões de Constituição, Justiça e Cidadania

CNJ - Conselho Nacional de Justiça

$\mathrm{CP}$ - Código Penal

CPC - Código de Processo Civil

CPP - Código de Processo Penal

e-gab-e-gabinete

EC - Emenda Constitucional

HC - Habeas Corpus

MC - Medida Cautelar

MS - Mandado de Segurança

OAB - Ordem dos Advogados do Brasil 
PEC - Projeto de Emenda Constitucional

PGR - Procuradoria-Geral da República

PV - Plenário Virtual

Rcl - Reclamação

RE - Recurso Extraordinário

RG - Repercussão Geral

RHC - Recurso Ordinário em Habeas Corpus

RISTF - Regimento Interno do STF

RTJ - Revista Trimestral de Jurisprudência

SECLA - Seção de Classificação de Assuntos

SEJ- Secretaria Judiciária

STF - Supremo Tribunal Federal

STJ - Superior Tribunal de Justiça 


\section{NOTA DE LEITURA}

Os termos identificados em itálico dizem respeito às expressões e categorias utilizadas pelos servidores e ministros do Tribunal. As aspas quando não identificam citações da literatura, identificam termos utilizados nas entrevistas. 


\section{INTRODUÇÃO}

Andressa: Qual o seu trabalho aqui?

Analista: Eu faço processo. Na verdade eu faço processo, carrego processo, faço processo, carrego processo. Me disseram que você está interessada em saber como é o nosso trabalho e eu posso resumir pra você o trabalho de todo mundo do tribunal, não só daqui da [Secretaria] Judiciária: todo mundo aqui faz processo e carrega processo. Se você ficar aqui meia hora vai ver que eu tenho razão. Mas não se engane, não é simples, envolve muitos detalhes. Sabe quando todo mundo diz que "Deus está nos detalhes", eu acho que não, é o direito que está nos detalhes.

Andressa: E o que são processos?

Analista: Processos são a vida do tribunal.

O interesse pela realização desta pesquisa surgiu em maio de 2008, quando assisti, através do Canal Justiça, ao julgamento pelo Supremo Tribunal Federal da chamada “Lei de Biossegurança". O Supremo, naquela ocasião presidido pela ministra Helen Gracie, hoje aposentada, iniciava o julgamento da ADI 3510 (Ação Direta de Inconstitucionalidade), impetrada pela Procuradoria Geral da República em 2005, que pretendia declarar inconstitucionais os artigos da lei que permitiam o uso de células tronco embrionárias em pesquisas científicas. Sob a relatoria do ministro Ayres Brito, esse processo talvez tenha sido o primeiro de uma sequência de outros julgamentos que, nas palavras do ministro Celso de Mello, apontam para a "aurora de um novo tempo". Naquele momento, o que me interessava era a decisão, seu conteúdo, as relações entre ciência e direito que foram evidenciadas no julgamento. Um interesse, posso aventar, naquela altura, informado por meu contato com pesquisas sobre ciência e tecnologia produzidas por autores como Bruno Latour, Michel Callon e John Law (Latour 2005), (Callon and Latour 1992; Callon and Law 1995). 
Iniciei o trabalho de campo propriamente dito, ou seja, assistindo aos julgamentos da corte no salão do plenário, apenas em setembro de 2010 e tenho a impressão que nunca acabei tendo em vista que mesmo que depois que parei de frequentar o tribunal, ele ainda frequentava meu dia a dia, não apenas porque estava escrevendo sobre ele, mas, sobretudo, porque as notícias do tribunal eram e são frequentes nos jornais de circulação nacional e nos debates de colegas que participo e acompanho.

Ao entrar no prédio do Supremo, pela primeira vez, tive uma sensação de estranhamento, pois não ouvi debatidos processos como o da "Lei de Biossegurança", isto é, processos nos quais embora desconhecesse pessoalmente parte do debate "técnico" acerca da constitucionalidade da lei, o objeto da ação não me era totalmente estranho. Naquela ocasião a discussão envolvia tributação e direito administrativo. Os ministros falavam em objeto da lide, writ, inconstitucionalidade formal e material, termos cujo sentido me era completamente alheio, cujo conteúdo até hoje, depois de uma pesquisa de campo de quase dois anos, precisamente um ano e oito meses, ainda não sou capaz de reconhecer com facilidade. Minhas primeiras anotações de campo eram palavras e expressões seguidas de um ponto de interrogação.

Outro estranhamento emergiu em relação à formalidade no tribunal. Como eu não sabia me vestir de modo adequado, fui barrada na primeira tentativa de ingresso no Tribunal. Posteriormente, quando lá dentro, tampouco soube antecipar quais eram os ritos e os comportamentos exigidos, como a hora de sentar e de levantar, ações que pareciam absolutamente naturais às outras pessoas que dividiam comigo as poltronas da assistência, todas elas, com seus ternos bem alinhados, ou seus tailleurs estruturados. Naquele momento me lembrava dos estudos de Garapon (1998), sobre os rituais judiciários. Segundo o autor, o que chama atenção em um tribunal, a princípio, não é o direito, mas o lugar e a mise-en-scène do processo.

Não demorei a compreender um pouco do que se passava, em certa medida porque pude contar com a solidariedade de alguns funcionários do plenário, já muito antigos no tribunal. Sabendo da pesquisa, essas pessoas muito gentilmente algumas vezes se sentavam ao me lado, traduzindo o debate com termos mais familiares e me advertindo sobre quais eram as questões importantes. Certa vez um desses funcionários me avisou: - Preste atenção quando forem julgar as pastas cor-de-rosa, é 
nelas que estão os debates mais importantes. Durante a tese, tento expor os critérios que fazem os processos mais ou menos importantes.

São as pastas cor-de-rosa que carregavam e carregam os autos processuais de uma ADI - como a da " Lei de Biossegurança". Existem várias pastas de cores diferentes que carregam processos de classes processuais distintas, alguns deles julgados no plenário, outros em reuniões menores de cinco ministros, denominadas turmas recursais. Todas as questões que são resolvidas pelo STF devem se encaixar em algumas das cores disponíveis, caso contrário, como vim a aprender, não chegarão ao tribunal. Embora os ministros e os funcionários digam o tempo todo, que a Constituição de 1988, "abriu as portas do tribunal", ou seja, facilitou a "subida" de processos ao STF, existem vários filtros que separam coisas e questões, que podem ou não ser julgados pelo tribunal que tentaremos identificar ao longo da tese.

Em 2013, um dos juristas mais citados pelos ministros do STF, o português José Joaquim Gomes Canotilho, concedeu uma entrevista ao jornal Folha de São Paulo, dizendo que o STF é um dos tribunais mais poderosos do mundo. Esse "poder" ao qual se referia o jurista, diz respeito ao que os ministros chamam de "competência", que não é só poder, mas um poder - dever, que os obriga decidir processos de vários tipos, tanto coletivos como individuais, os "relevantes" ou os "ladrões de galinha". Foi com a ampliação dos tipos de processos passíveis de serem julgados pelo STF, que o tribunal garantiu maior espaço nos debates de questões públicas tidas, a princípio como objetos exclusivos da política, tornando-as passíveis das transformações técnicas que impulsionam o processamento.

Aos poucos fui me acostumando com a liturgia daquele universo. Ainda assim, mesmo tendo decodificado minimamente o julgamento, descobri que dali não seria capaz de dizer muito coisa sobre as operações que acontecem no tribunal, tendo em vista que os julgamentos são uma pequena e, às vezes muito rápida, parte de todo processo. Várias vezes, sentada no plenário, ouvia um caso sendo apregoado para que fosse decidido e, em menos de dez minutos, o mesmo estava resolvido. $\mathrm{O}$ ministro relator - aquele que resume o caso para os demais ministros - tornava pública sua conclusão, os colegas acompanhavam seu voto e o presidente proclamava o resultado. Em algumas dessas vezes, anotei o número do processo para procurá-lo 
posteriormente e descobrir que tais casos estavam no tribunal à espera do julgamento fazia alguns anos. Me perguntava o porquê desse vagar: - o que se estava aguardando?! Do meu ponto de vista, essas não me pareciam decisões difíceis ou polêmicas que exigissem tamanha maturação. Hoje posso sustentar que existem várias respostas formuladas no tribunal para essa pergunta. No entanto, sem me ater a todas elas, o que me parece mais importante é constatar que existe um tempo necessário para que um processo seja "feito" e, nesse sentido, a duração de um julgamento tornase irrelevante ou absolutamente menos importante do que o tempo do processamento.

Durante o trabalho de campo, longe dos julgamentos, acompanhando o dia a dia da corte em alguns de seus setores, consegui perceber a importância de entender como se fazem os processos, a fim de compreender as técnicas envolvidas na produção do direito. Conforme já observara Bevilacqua (2011), me dei conta de que "[o] pensamento jurídico "técnico" deixa-se apreender no meticuloso encadeamento de documentos de diferentes tipos e de argumentos provenientes de fontes diversas que, em conjunto, constituem os autos de demandas judiciais concretas" (2011, p.3).

O interesse pelo "fazer processos" não estava tão distante do meu interesse inicial pela decisão em si. No decorrer da pesquisa percebi que "fazer processos" e "fazer decisão" não dizem respeito apenas ao conteúdo daquilo que é enunciado pelos ministros. Tomo, assim, a decisão como objeto, no sentido de Riles (2011), que articula técnicas, procedimentos e temporalidades distintas e que permitiu deixar de lado avaliações que se restrinjam à sua eficácia e referencialidade de um só momento, mostrando-a em estado de devir. Na esteira do conceito de obviação desenvolvido por Roy Wagner (1986), uma decisão criaria duas coisas, uma metáfora (seu conteúdo) e um símbolo não referencial, ou seja, um objeto material. A tese tenta percorrer e articular essas duas dimensões ainda que a ênfase esteja na materialidade dos objetos.

A etnografia que apresento, não trata dos juízes, ou pelo não enfatisa apenas suas acões, seus convencimentos ou suas idiosincrasias, nem tão pouco fala das decisões e seus conteúdos específicos. Não proponho um diálogo ancorado em uma suposta ontologia dos tribunais. $\mathrm{O}$ interesse está nos objetos, como processos, procedimentos e relações que instanciam o tribunal. 
Quando se "faz um processo" para "fazer uma decisão", forma e conteúdo se misturam não existindo uma clara distinção entre fundo e figura, assim como são misturados/ borrados, sujeitos (de direito) e objetos (do direito). Compreendidos, a partir do trabalho de pesquisa que empreendia como as mais interessantes produções na operação jurídica do Supremo Tribunal Federal, aos processos, dedico as meditações desta tese de doutoramento. Pretendo durante as páginas que seguem acompanhar as formas de fazer processos e fazer decisão, sobretudo como objetos que acumulam legitimidade, procedimentos, expertises e temporalidades.

A pesquisa etnográfica tenta articular os espaços do tribunal, a agência dos atores e das formas legais, com vistas a compor uma imagem que atenda ao objetivo de uma compreensão ainda que parcial, das formas como as coisas se passam no STF: como são produzidos processos e decisões? E ainda outras questões que ativam um conjunto de relações e temporalidades entre pessoas e coisas, causas e pessoas, causas e coisas. Esses conjuntos são transformados em processos na dupla acepção que o termo processo possa aludir: como um fluxo de transformações e como um amontoado amarfanhado de papel.

Não pretendo nesta tese compreender o direito operado no STF como um artefato da cultura, a partir de sensibilidades jurídicas que lhe seriam singulares. Em suma, não pretendo analisar as decisões em seus conteúdos específicos. O objetivo da pesquisa foi compreender a produção dos processos e das decisões do tribunal, a partir de seus próprios artefatos, formas legais, expertises, procedimentos técnicos, atentando para as transformações envolvidas na prática jurídica e para as práticas de conhecimento evidenciadas nos fluxos do processamento de uma ação judicial no Supremo Tribunal Federal. O interesse que nutro encontra ressonância em pesquisas na área de antropologia do direito igualmente preocupadas com o conhecimento jurídico a partir de suas tecnicalidades (Riles, 2005; 2006) e das práticas que fazem direito (Latour 2010).

A presente pesquisa não coloca ênfase, portanto, no discurso normativo do direito. Ela se volta para as formas e práticas que fazem direito, fazendo processos. Mariana Valverde (2007) destaca que ao colocar foco no conhecimento legal ao invés da autoridade, o direito pode ser considerado não um sistema dotado de autoridade e 
autonomia particular, mas como uma prática de conhecimento entre outras, como a antropologia, por exemplo. Não se trata aqui de uma análise que parte de configurações estruturais, campos ou sistemas preexistentes (Pottage, 2012), mas que destaca as qualidades legais, a partir dos fluxos dos processos, que permitem aos analistas judiciários e aos ministros do STF reconhecer, separar, classificar, transformar os objetos dos autos em questões jurídicas sobre as quais outras transformações técnicas serão operadas para que depois se tornem precedentes configurando jurisprudências.

Os insights dos estudos de ciência e tecnologia, aos quais me referi, sobre produção e circulação de conhecimento, ganham assim relevo na pesquisa, na medida em que destacam o conhecimento e, no nosso caso, o conhecimento jurídico, como parte de uma rede maior e mais abrangente, para além da mera decisão e seu conteúdo normativo e da atuação isolada dos juízes no tribunal.

\section{OS AUTOS PROCESSUAIS E SUAS MATERIALIDADES}

Law (1992) ao destacar alguns critérios metodológicos da Teoria do Ator Rede argumentou que o conhecimento sempre assume formas matérias. Está nas falas, nos artigos, mas também nas habilidades incorporadas em cientistas e técnicos (Latour e Woolgar, 1979). Conforme o autor, o conhecimento é, portanto corporificado e materializado em várias formas, sendo produto de uma rede de elementos heterogêneos como tubos de ensaio, reagentes e organismos.

Ao experimentar os mesmos pressupostos das pesquisas científicas com a produção jurídica, a partir de uma etnografia no Conselho de Estado Francês, Latour (2010) destaca a circulação dos autos processuais e seus elementos materiais - carimbos, textos e, sobretudo documentos - como sendo a matéria-prima que transporta o direito no conselho. Conforme o autor, os documentos servem como "ferramenta de inscrição", permitindo a construção de verdades epistemológicas (fatos), devido ao seu caráter "móvel”, ainda que igualmente imutável e combinável. Documentos são, portanto, constitutivos do próprio tribunal. Não apenas em seu conteúdo, mas também 
em suas formas gráficas, na disposição e organização das informações, que os tornam reconhecíveis e transformáveis.

Existe uma vasta literatura antropológica, mais ou menos recente, (Cohn, 1987; Das, 2004; Feldman, 2008; Ferreira, 2011, 2013; Foucault, 1977; Goody, 1977; Gupta, 2012; Hull, 2012a; Latour, 2002; Riles, 2006a; Sharma e Gupta, 2006; Weber, 2005 [1922]), que enfatiza o quanto os documentos ${ }^{1}$ não são apenas instrumentos, mas são também mediadores que padronizam ações e representações entre diferentes tipos possíveis de expertises acionadas na atividade de análise e investigação de processos (Riles, 2011a:59). Nesse sentido esses instrumentos/ mediadores da burocracia judicial compõem as operações jurídicas, não como assessórios, mas como parte dos processos e parte das decisões.

Cabe aqui um parêntese a fim de explicitar que se entende, como materialidades. Conforme Pottage (2012), a maioria dos estudos de agência material começa em meio às coisas, descrevendo detalhadamente conformações, disposições e operacionalidade dos meios técnicos. Segundo o autor, o que realmente importa não é a simples materialidade dessas coisas, sua massa, sua densidade, mas sim a "materialidade" como um tipo de agência que lhe é atribuída. A agência material não é uma qualidade inata desses artefatos, senão um efeito da operacionalidade dos meios técnicos.

Ao acompanhar os processos de documentação e os documentos que circulam no tribunal, tento rastrear os procedimentos que "fazem processos". Desse modo, procuro nesta tese, demonstrar que esses procedimentos envolvem formas de classificação, filtragem e administração que constituem as questões jurídicas contidas nos processos, ou seja, os objetos legais que circulam com os autos. Esses procedimentos

${ }^{1}$ O uso da expressão "documentos" tem sido usado, na literatura antropológica recente, como alternativa às expressões "textos" ou "representação", tendo como objetivo deslocar a ênfase dos aspectos discursivos e referenciais das formas burocráticas de documentação, para suas características materiais e estéticas, como a organização do espaço gráfico, modelos de documentos, a qualidade ou tipo de papel, assinaturas, entre outras (Hull, 2012b). 
são dirigidos por pessoas em setores distintos, que se relacionam através da troca dos autos, do sobe e desce das pastas coloridas, que vão sendo transformados ao longo de sua circulação. No sentido de Riles (2008), essas rotinas são menos um conjunto de normas compartilhadas, mas, sobretudo um conjunto de "critérios estéticos" que permitem que os operadores decidam quais as formas e fórmulas aplicáveis (p. 56).

\section{A TÉCNICA, OS CONVENCIMENTOS E AS SENSIBILIDADES}

A partir da segunda metade da tese, procuro rastrear algumas técnicas de interpretação que revelam os sentidos a as extensões do texto constitucional, apresentando alguns dos critérios e os instrumentos ativados pelos ministros nas resoluções dos processos, evidenciando as formas como as normas são "aplicadas" nos termos locais. A definição e construção dos objetos jurídicos e suas resoluções implica numa variedade de práticas instrumentais e expressivas que não necessariamente se combinam num todo coerente, formando um só objeto (Mol e Law, 2004). Além das técnicas, alguns tipos de processos ativam o que os ministros chamam se sensibilidade, que aparecem em questões com maior repercussão ou mais "delicadas" e evolvem outros recursos que não apenas os técnicos.

Chamo atenção também para algumas dimensões da política do tribunal, relacionada, sobretudo, as disputas de convencimentos no plenário e a liberação e pauta dos processos que envolvem avaliações acerca das possibilidades que determinados entendimentos sejam consolidados pelo corpo de ministros, assim como sobre as possibilidades de mudanças de orientação.

\section{TRAJETÓRIA DA PESQUISA}

Para chegar até o gabinete é preciso de um crachá, adquirido na entrada do prédio quando nos identificamos através de documento com foto. O funcionário terceirizado cadastra o visitante, tira um foto. Em seguida passo por um detector de metais e uma primeira catraca. Para chegar ao gabinete passo por outra catraca. Na antessala do gabinete uma mesa redonda, lugar onde os advogados esperam para serem recebidos 
pelo ministro nas audiências. Nesse dia dois estavam esperando, um deles jurista português que faz pareceres em um escritório especializado em tribunais superiores, um desses casos estava sob a relatoria do ministro.

Um funcionário sai da sala, pergunta se sou Andressa Lewandowski, e me avisa que serei recebida em breve pelo ministro. Quando volta para sala, os advogados fazem a pergunta esperada: Você é filha do ministro Lewandowski? Não, não sou filha do ministro. Para os advogados falo da pesquisa, o motivo de eu estar ali. Eles se mostram interessados, me contam algumas histórias, me recomendam livros, pessoas que se interessariam em conversar comigo sobre produção do direito, sobre racionalidade, sobre os procedimentos.

Eles logo são chamados, antes de entrarem me passam seus contatos, desejam boa sorte. Uns 10 minutos depois eles voltam, e eu sou chamada em seguida. O funcionário me fez me faz algumas recomendações, em especial sobre o tempo. $O$ ministro tem compromissos, então ele entrará na sala eventualmente para me apressar. Sento em outra cadeira, em frente à sala do juiz. Na minha frente, e por todos os lados processos, muitos processos no chão. Quando a porta abre confesso que fiquei um pouco nervosa, na verdade não sei como chama-lo. Se chamo de Vossa Excelência ou só de ministro. Ele vem me cumprimentar. Muito cordial. Entro então naquela sala enorme, com grandes janelas e um jardim do lado de fora, tudo muito organizado. Não existem processos pelo chão. Compõe o ambiente uma grande estante de livros, a mesa de trabalho e outra mesa redonda onde me sento. Na parede muitos diplomas pregados, certificados, algumas fotos. O ministro ainda resolve algumas questões com seu assessor antes de começar a conversa. Pede que ele guarde o livro que ganhou de presente do advogado. Diz que vai dar mais uma olhada em determinado processo, parece ser aquele sobre o qual os advogados vieram conversar. Fala então para o analista que no relatório que recebeu não havia algumas informações que lhe pareciam relevantes. Pede um novo relatório. Senta em sua cadeira, olha para um papel em sua mesa e me diz: Me fale de você. De novo falo da pesquisa, de tudo que já vi que já fiz do que ainda quero fazer. Ele se anima, fica feliz por alguém de outra área se interessar pelo tribunal e então pergunta: Em que eu posso te ajudar? Pergunto da sua trajetória como juiz, da sua 
indicação para Corte. Depois disso quase não pergunto nada. Ele fala o que acha que eu quero saber. (trechos do caderno de campo)

A pesquisa no Supremo Tribunal Federal teve início antes mesmo de se tornar uma pesquisa de fato. Desde 2008 vinha assistindo as sessões de julgamento do tribunal, realizando anotações das coisas que me pareciam interessantes, notas que posteriormente "desapareceriam" no decorrer do trabalho de campo. Em 2010, já cursando doutorado, tentei os primeiros contatos com o tribunal para realizar a pesquisa, e nesse primeiro momento não obtive respostas nem positivas nem negativas. Meus futuros anfitriões apenas me diziam que entrariam em contato, o que não acontecia. Passei a frequentar o arquivo do tribunal, um espaço de acesso público além de alguns dos julgamentos. Permaneci no arquivo lendo processos durante dois meses. Como conhecia poucos processos pelo número, solicitava ao servidor os processos que mais vezes apareciam na lista de controle do setor, ou seja, os mais solicitados tantos por advogados quanto pelos gabinetes. Desse modo, fui reconhecendo as formas e os documentos que compõem aos autos, os carimbos e as assinaturas dos diferentes setores e em alguns dos processos, anotações realizadas pelos gabinetes em post-it amarelos colados nos autos, me dando conta, através de todas essas inscrições, das trajetórias dos autos no tribunal.

Frequentando o arquivo, que também me permitia frequentar o restaurante do tribunal, conheci alguns dos analistas judiciários que foram fundamentais no decorrer dessa pesquisa, e me deram pistas de como conseguir entrar no tribunal, nos setores de acesso restrito. Esses analistas me advertiam sempre que seria difícil conversar com os funcionários do tribunal, dado que havia certo receio em qualquer tipo de exposição que de alguma forma pudesse prejudicá-los. Dizia a eles que meu interesse não estava em saber o que não poderia saber, mas ao contrário, eu estava interessada no trabalho, no que faziam esses funcionários, quais eram suas atribuições, como gerenciavam os processos. Eles, no entanto, tinham razão. No decorrer da pesquisa acabou se mostrando mais fácil conversar com os ministros do que com os analistas e técnicos do tribunal. 
Ainda no arquivo, passei a frequentar a sessão das turmas recursais, que acabara de descobrir, também eram abertas aos advogados e interessados em geral. Enquadrada na segunda categoria - dos interessados em geral - conheci esse outro espaço do tribunal e mais alguns servidores. Os funcionários mais antigos do plenário e das turmas haviam trabalhado com alguns ministros aposentados do STF, e através deles, entrevistei três ministros que já não compõem o tribunal, embora, como veremos adiante, essa expressão que os "tira de cena" não seja em absoluto a mais apropriada.

Durante todo o tempo em que permaneci no arquivo, tentei conseguir autorização para realizar a pesquisa na secretaria judiciária, setor do tribunal que gerencia todo processamento, recebe, classifica, remete etc, dentre outras centenas de procedimentos. Em minhas tentativas fui sempre avisada de que precisaria de autorização formal, embora ninguém soubesse exatamente como eu poderia conseguila, nem com quem. Imagino que por insistir tanto, alguns dos analistas aceitaram conversar comigo desde que mantivesse seus nomes em anonimato. Assim o fiz. Eles adianto, não me contaram nada que eles mesmos classificassem como segredo. Esse tipo de classificação envolve quase sempre questões relacionadas aos ministros, algum possível erro que tenham cometido ou alguma ingerência de seus gabinetes, além das relações internas entre os juízes.

Nos gabinetes minha estratégia foi parecida. Comecei enviando e-mail ao servidor que marca as audiências - que acontecem entre ministros e advogados, explicando-lhe que meu caso era um pouco diferente. Esses e-mails eram encaminhados ao chefe de gabinete que me respondia quase sempre da mesma forma: "Vamos despachar o ministro". Uma única vez um chefe de gabinete me atendeu prontamente. E esta foi exatamente a única vez em que assinei meu nome completo no e-mail. Não posso deixar de dizer que dividir o mesmo sobrenome com um dos ministros da corte, com quem guardo parentesco distante, não ajudou tanto quanto se possa imaginar. Algumas vezes, quando um analista aceitava conversar comigo, sentia-se intimidado pela possibilidade da conversa ser divida com o ministro.

De todo modo, às coisas começaram a funcionar quando adotei a estratégia de falar diretamente com os ministros, tentando fugir dos seguranças que os circulam. $\mathrm{Na}$ realidade, entrevistar os ministros acabou não sendo a parte essencial da pesquisa. No 
entanto, apenas através deles tive acesso aos gabinetes e aos demais setores do tribunal. Certa feita, no intervalo de uma das sessões cruzei com um dos ministros no corredor que dá acesso ao salão que fica atrás do plenário. Contei a ele da pesquisa e do interesse nos trabalhos do gabinete. Sua Excelência me disse que não haveria problemas, mas que era preciso marcar com o chefe de gabinete. $\mathrm{Na}$ hora tive certeza que ele havia me dito que não tinha problema, como uma fala protocolar e que na verdade nada aconteceria. Estava enganada, fui recebida pelo chefe de gabinete e além de entrevistar o ministro passei alguns meses acompanhando a produção dos processos. A partir desses périplos iniciais e primeiras portas que se abriram, a pesquisa foi se tornando mais real e mais possível. Aprendi como as coisas funcionam, a quais os setores deveria me dirigir, que tipo de documentos deveria apresentar. Tive acesso a outros gabinetes, conheci outros analistas e técnicos e, por fim (ainda que com procedimentos específicos sobre os quais vou falar no capítulo 2), fui autorizada a acompanhar os trabalhos da Secretaria Judiciária.

Esta tese pretende apresentar justamente uma composição etnográfica a partir desses espaços de intervenção. O que circula por esses espaços visto do ponto de vista de minha própria circulação, permitiu com que eu identificasse os encontros entre os processos, pessoas, lugares, tempos, normas e socialidades que pretendo explorar.

Faço agora uma síntese do que desenvolverei no decorrer da tese, com vistas a explicitar a produção etnográfica aqui empreendida acerca das formas e das técnicas.

\section{DIVISÃO DOS CAPÍTULOS}

No primeiro capítulo apresento algumas transformações que envolvem as noções de técnica e política a partir de espaços de intervenções dos ministros do tribunal, no processo Constituinte de 1988. Tento apresentar a relação de transmissão e transformações que a Constituição 1988 estabelece, tendo em vista que se tratou de um período de transição entre um regime ditatorial para o democrático, no qual a ideia de "Constituinte Originário" se amalgamou da "vontade do povo", e ainda que não imediatamente, o STF foi transformando suas competências, ocupando o lugar que supostamente a Constituição reservou- lhe, como agente fundamental da na vida 
política e social do país. A consolidação democrática dá nova visibilidade aos tribunais, estabelecendo novas relações entre quem e o que o tribunal representa. Chamo atenção também no primeiro capítulo, para os lugares e as competências do tribunal, além das transformações que passam os próprios ministros.

No capítulo dois tendo rastrear a produção e circulação dos processos nos gabinetes e na Secretaria Judiciária, com vista a compreender, os modos de operação, as técnicas e procedimentos envolvidos na composição e maturação dos autos processuais. Apresento então, os filtros, os tipos de classificações, as pesquisas e as relações entre pessoas que fazem processos e suas percepções sobre o trabalho que realizam. Procuro demonstrar que os fluxos do processamento envolvem temporalidades e passagens entre fases diferentes dos processos, cada um delas cercada de protocolos que garantem uma composição apropriada dos autos processuais.

O terceiro capítulo se concentra nas técnicas de interpretação constitucional e nos critérios e transporte de "objetos de valor" (Latour, 2010) que são acionados na solução dos casos. Tendo identificar o papel dos precedentes e da doutrina jurídica como formas que asseguram um equilíbrio entre convecção e invenção no sentido de Wagner (2012).

Por fim, rastreando a circulação dos processos, chegamos ao plenário do Supremo. Ao apresentar o julgamento procuro identificar o papel dos atores e as disputas de convencimento que se desenvolvem durante a sessão, destacando as relações entre o processo e os objetos do julgamento. Procuro demonstrar que a verdade dos processos, são aquelas passíveis de serem extraídas nos documentos e que uma decisão seria menos uma constatação das coisas que acontecem ou aconteceram fora do processo, mas, sobretudo, daquilo que o próprio processo e o processamento faz emergir. 


\section{CAPÍTULO 1 - A CONSTITUIÇÃO COMO FORMA DO DIREITO}

Pretendo apresentar nesse capítulo o que me parece ser a noção central de toda a tese: a ideia de transformação. A partir de breves paradas em espaços de intervenção dos ministros, pretendo demonstrar como o poder político se transforma em competência jurídica, como os próprios ministros passam também por um tipo de transformação que permite que ocupem determinada posição, e como o lugar - tribunal - também vai se transformando. Nessa sequência de coisas, existe uma convergência que também me parece central entre política e direito. Esses dois registros e categorias ora se encontram, ora se separam através da noção de técnica jurídica.

Não me cabe aqui contar a história do Tribunal, porque a história linear, ou a sequencia de eventos não funciona para o que pretendo capturar. Minha reflexão busca contribuir para repensar o tribunal e reconfigurar a história linear a partir de temporalidades distintas. Os dados que apresentarei, relacionados ao STF, e o processo constituinte têm por objetivo pontuar modos de intervenção dos ministros, os limites imanentes e transcendentes de suas atuações, com vistas a estabelecer o que une e o que separa o direito da política. Adiante adentrarei no universo das competências e dos lugares, tentando compor o cenário em que tudo se passa.

É na Praça dos Três Poderes, a alguns metros do Congresso Nacional e do Palácio do Planalto, que se localizam os prédios do Supremo Tribunal Federal. Em frente ao prédio principal existe uma escultura, obra de Alfredo Ceschiatti. Chama-se Justiça. Trata-se de uma figura feminina, sentada e com os olhos vendados. Representa a personagem mitológica Themis, filha e conselheira de Zeus, conhecida por ser a deusa da Justiça. A figura, além dos olhos vendados, carrega uma espada na mão. Símbolos da imparcialidade e da força. No entanto, a deusa grega está de costas para o Tribunal, parecendo exibir sua força às outras duas instituições, que somadas ao Judiciário compõem os três poderes da República.

No primeiro prédio, obra do arquiteto Oscar Niemeyer, imensas janelas de vidro permitem ver o grande salão do plenário do lado de fora. É nele que os juízes do Tribunal decidem os casos, ou, pelo menos, declaram seus votos sobre os processos. 
O imponente prédio principal, olhado de longe, parece não tocar o chão, como se os doze pilares em curva que sustentam o prédio flutuassem. À noite, o efeito das colunas suspensas é ainda mais notável com um jogo de luzes no chão e no teto.

Uma das primeiras vezes que estive no plenário foi para assistir ao julgamento de um dos muitos tipos de recursos, chamado de Recurso Extraordinário. Era o RE 603583, proveniente do Rio Grande do Sul e impetrado por um bacharel em direito. Este recurso, até chegar ao Supremo, percorreu todos os caminhos possíveis no interior do sistema judiciário, na denominada "Justiça comum" - não especializada. Começou

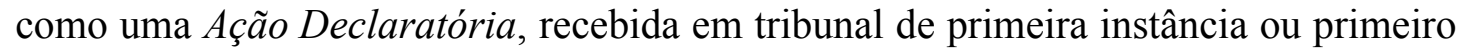
grau, como uma Ação Originária, sendo julgada por um juiz federal singular. Com esse processo o autor pretendia que se declarasse a inexistência de relação jurídica obrigacional em prestar o exame da Ordem dos Advogados do Brasil para inscreverse como advogado na Ordem os Advogados do Brasil. Vale destacar que o autor não pretendia que o juiz declarasse o exame inconstitucional, apenas que o bacharel não seria obrigado a prestar o exame. Contudo, todos os argumentos sustentados nos autos buscavam demonstrar a inconstitucionalidade do denominado Exame da Ordem. A questão constitucional aparecia como incidental no processo. Tratava-se de um processo de controle difuso de constitucionalidade, realizado em casos concretos, ou seja, quando existem pessoas nos processos, sejam elas físicas ou jurídicas, com interesses específicos.

Tendo sido o pedido indeferido, o processo seguiu então para segunda instância ou segundo grau, já como recurso, sendo então julgado por um colegiado de juízes, os desembargadores federais. Ainda não conformado com a decisão, o impetrante seguiu com o processo para o Superior Tribunal de Justiça, a corte responsável por uniformizar a interpretação da lei federal tida como infraconstitucional. Por fim, chegou então ao Supremo Tribunal Federal, a última instância possível para um recurso. Embora exista uma tendência de alguns tipos de processos a ascender às instâncias superiores, nem todos serão julgados pelo STF; no caso de recursos extraordinários, o Tribunal escolhe qual processo irá julgar. Isso ficará mais claro no capítulo seguinte. Nessa carreira ascendente dos processos, o que era apenas uma questão constitucional incidental converte-se na questão central da demanda, possibilitando que o recuso submetido ao STF seja considerado como extraordinário. 
Em alguns casos é o próprio Tribunal que manda subir os autos. Tentarei aclarar esse procedimento.

Um RE é apresentado no tribunal de origem do processo, que então pode encaminhálo ao Supremo Tribunal Federal ou negar-lhe seguimento. Na origem são verificados os requisitos de admissibilidade de um recurso extraordinário constante, tanto na legislação como na jurisprudência do STF. Quando negado no tribunal de origem, o requerente pode ainda entrar com outro recurso chamado agravo, diretamente no STF, que então pode mandar o recurso subir.

O RE 603583 chegou ao STF no dia 23/9/2009, agora sim, questionando a constitucionalidade do exame da ordem diretamente, o que significa que outras folhas foram incorporadas ao processo, destinadas a convencer os ministros de que ali existe uma questão constitucional de "interesse público". Embora a trajetória desse recurso no interior no STF não interesse por ora, ele foi escolhido pelo plenário virtual como caso exemplar, cuja decisão irá valer para outros recursos que tenham o mesmo objetivo, ganhando, portanto, repercussão geral, termo que marca a mudança de status de um processo.

A repercussão geral é dada aos processos que demonstrem a existência de questão constitucional relevante e que ultrapasse os interesses tidos como subjetivos da causa, ou seja, o processo não é mais considerado apenas de um sujeito específico. $O$ suposto da repercussão geral permite ao Tribunal escolher um caso entre vários, considerando que outros pleiteiam a mesma coisa. Assim o julgamento estabelece um paradigma de decisão com força vinculante, ou seja, todas as decisões de tribunais inferiores estarão vinculadas à decisão proferida pelo STF.

O procedimento interno de seleção dos processos funciona a partir de uma plataforma eletrônica denominada plenário virtual. Através dela os ministros podem votar sobre aspectos formais do processo, respondendo a um tipo de questionário disponível, no sistema, via intranet. Esse sistema permite também que os advogados das partes acompanhem a votação via internet. Sinteticamente, funciona da seguinte forma: o relator do recurso encaminha seu relatório escrito para os demais ministros, que respondem negativa ou afirmativamente o questionário (ver anexo 2) contendo as 
duas perguntas: há questão constitucional? Há repercussão geral? Se a maioria decidir positivamente que se trata de uma questão constitucional com repercussão geral, um recurso pode então ir a julgamento não mais como um caso individual. Outros processos com o mesmo objetivo, em tramitação tanto na corte como em outros tribunais, ficam aguardando esse resultado procedimento denominado sobrestamento.

No dia 26/10/11, quase quatro anos depois de seu ingresso no sistema judiciário, o RE em questão entrou na pauta para ser julgado pelo plenário, julgamento esse que vai nos ajudar a levantar algumas das questões relevantes para esta tese.

$\mathrm{Na}$ entrada do STF, no dia 26, formou-se uma longa fila. Frequentei o arquivo do Tribunal durante algum tempo antes de assistir a um julgamento; poucas vezes vi tantas pessoas aguardando para entrar no plenário. $\mathrm{Na}$ fila, muitos estudantes de direito, alguns já formados, mas ainda não advogados, que estavam ali justamente para saber se o Exame da Ordem, capaz de transformar bacharéis em advogados, era válido. O Tribunal submeteria o exame a um teste de constitucionalidade e decidiria se o exame está de acordo com a Constituição Federal.

Enquanto esperava para passar pelo detector de metais que dá acesso à primeira sala, pude escutar a conversa de três rapazes sobre o julgamento. Alguns deles antecipavam os votos dos ministros pela inconstitucionalidade do exame, certos de como alguns votariam.

- Ayres Brito vai votar pela inconstitucionalidade. Esse é um voto certo.

- É, mas temos o Joaquim, que deve votar também. Se ele estiver no julgamento.

- Será que eles sabem que a vida de muita gente depende do que eles vão dizer hoje? 
- Esse negócio é todo errado, deveríamos poder opinar. Esses caras não podem fazer o que quiserem.

- Muita gente mandou e-mail para os ministros. A caixa do Ayres Brito deve ter lotado. Ele vai se sensibilizar com nossos argumentos.

Essa conversa entre os três rapazes logo se espalhou entre outros estudantes e bacharéis que estavam próximos, alguns vindos de outros estados apenas para assistir ao julgamento. Concretamente, os estudantes e bacharéis tinham a seu favor um parecer entregue pela Procuradoria-Geral da República, que constava nos autos, cujo entendimento era o de que o exame deveria ser declarado inconstitucional.

Enquanto isso, um homem passava por toda a fila distribuindo cópias da Constituição Federal ao público. Ele era o responsável pelo recurso, uma parte no processo, embora, como visto, o que há de especifico em seu caso não seja exatamente o que deve motivar a decisão dos ministros.

Poucos minutos depois, o presidente da Ordem dos Advogados do Brasil, a outra parte no processo, também chegou. Conhecido que era dos funcionários, não ficou na fila, entrando diretamente no salão. Qualquer advogado que tenha causa pautada pelo Tribunal para julgamento não precisa enfrentar a fila da porta. Para eles existem cadeiras reservadas no plenário. O presidente da OAB não foi ao STF apenas como parte, mas também como advogado da entidade.

Iniciada a sessão no plenário, uma primeira decepção aos bacharéis. O ProcuradorGeral da República mudou o entendimento do parecer constante nos autos, provocando reações do público que, embora não possa se manifestar durante o julgamento, esbravejava contra o novo parecer. Rapidamente os seguranças do tribunal entraram em ação garantindo a ordem para que a sessão continuasse.

Durante as sustentações orais, os advogados da defesa ressaltaram a falta de legitimidade do Conselho da Ordem dos Advogados para regulamentar o exercício da 
advocacia. O exame afrontaria o princípio constitucional do livre exercício da profissão, violaria o princípio da igualdade e seria apenas um mecanismo de reserva de mercado. Por outro lado, tanto os representantes do Conselho Federal como da Advocacia-Geral da União defenderam, ocupando a tribuna, a importância da advocacia na defesa das liberdades e a necessidade do conhecimento técnico na garantia de justiça. Argumentaram que o constituinte originário delegou à Ordem dos Advogados a missão de integrar a administração da Justiça, da mesma forma como delegou ao Supremo Tribunal Federal a competência para julgar processos como esses, que abrem a chamada controvérsia constitucional.

Já nos votos declarados em plenário, a ministra Carmem Lúcia destacou:

- O advogado foi pensado nessa Constituição como profissional que garantiria o Estado Democrático de Direito. Porque o direito é técnico e seria necessário à comunidade de técnicas com a ética e o conhecimento jurídico o bastante para fazer valer.

É verdade que a Constituição pensou nos advogados. Em uma breve leitura da Carta Magna de 1988 é possível encontrar 61 referências tanto a advogados e à advocacia como ao Conselho da Ordem dos Advogados. Nenhum outro conselho é citado expressamente no texto. A Ordem dos Advogados integra o sistema de justiça e é também responsável por sua administração, sendo a justiça um dos valores supremos declarados pela Constituição Federal.

Uma Constituição é tida como um documento jurídico-político e se movimenta entre essas duas esferas. Sua legitimidade está diretamente relacionada ao chamado poder constituinte originário - citado, por quem defendia a validade do Exame da Ordem, como um poder ilimitado, absoluto e não jurídico. O constituinte originário na fala tanto dos ministros como dos advogados, tem vontades, autoriza e restringe atuações e competências. Embora, como já destacara o filósofo Antônio Negri (2002) em obra 
dedicada ao conceito, o poder constituinte não possa ou não deva ser reduzido ao poder de criação de um novo ordenamento jurídico, para as ciências jurídicas, de modo geral, esse poder exerce o papel de "mito fundador e legitimador da ordem constitucional" (Bercovici, 2013).

Negri argumenta que o conceito de poder constituinte é expressão de potência imanente, de produção criativa, não se configurando como fonte transcendente do poder constituído. Seria um poder por natureza contrário à ordem constitucional; em última instância, um poder contra o Estado. No entanto, segundo o autor, ao ser judicializado o poder constituinte se transformaria em extraordinário, sendo resumido em um evento e encerrado em uma factualidade somente revelada pelo direito.

Para além da transcendência ou da imanência, Niklas Luhmann (1998) aponta o poder constituinte como aquele que inventa um mecanismo de acoplamento estrutural entre o sistema do direito e o da política: a Constituição. Esta, ao mesmo tempo que aproxima esses dois sistemas, os diferencia. Segundo o autor, é por meio da Constituição que a política se deixa regular pelo direito.

Conforme o hoje ministro do Supremo Tribunal Federal Roberto Barroso:

A Constituição é, precisamente, o documento que transforma o poder constituinte em poder constituído, isto é, Política em Direito. Ela então se sujeita 'aos cânones de racionalidade, objetividade e motivação das decisões judiciais, devendo reverência à dogmática jurídica, aos princípios de interpretação e aos precedentes' (BARROSO, 2008:18).

Depois de promulgada a Constituição, já transformada em ordenamento, se submeteria a um tipo específico de racionalidade - como o afirmou a ministra Carmem Lúcia: o direito é técnico. Antes disso seria objeto próprio da política. Um 
processo constituinte, como no caso brasileiro de 1987, expõe disputas de interesses políticos diversos e contrários. Uma disputa que envolve o "povo" (em teoria, o verdadeiro detentor do poder constituinte) e aqueles que representam um poder já constituído. A Assembleia Nacional Constituinte (ANC) instalada em 1987 tanto levou o "povo" a ocupar as galerias do Congresso Nacional e a propor as chamadas "emendas populares", como mobilizou ministros do STF e juristas a propor acordos, defender suas demandas e negociar projetos, em busca de consensos possíveis, submetidos à lógica da política, sem seus critérios técnicos de operação.

Já na emenda constitucional $n^{\circ} 26$, aquela que convocava membros da Câmara e do Senado a se reunir em Assembleia Nacional Constituinte, o presidente do Supremo foi chamado a presidir a ANC até que os deputados e senadores pudessem eleger um presidente. Em seu discurso de abertura, o então presidente do STF, ministro Moreira Alves, discorreu a respeito da tradição constitucional como lei fundamental que rege todo ordenamento jurídico, mapeando as constituições brasileiras desde o Império. Segundo o ministro, embora em certos momentos as Constituições "percam sua força mítica perante o homem comum para o qual foram, outrora, um ideal", tal fato não se relaciona necessariamente à forma com que foram elaboradas ou a seus conteúdos, mas às contingências em sua aplicação. Naquela solenidade, Moreira Alves concluiu seu discurso pedindo prudência aos ora constituintes contra o que chamou de “devaneios utópicos". Evitou falar em ruptura constitucional, fazendo alusão à transição, numa conciliação que "encerra o ciclo revolucionário sem rupturas".

Essa postura de continuidade, segundo os cientistas políticos Koerner e Freitas (2013), foi dominante entre os ministros do Tribunal naquela ocasião, os quais compartilhavam um mesmo argumento. Para os juízes o problema não era o texto da Constituição de 1967, mas sua "inexecução", como o teria dito o ministro Oscar Corrêa. Quando entrevistei alguns ministros aposentados do Tribunal, que participaram do momento constituinte, não me pareceu claro quais eram os impulsos das ressalvas, mas levanto aqui uma hipótese.

Talvez as ressalvas a um processo constituinte estivessem relacionadas justamente ao poder constituinte - por definição não submetido à racionalidade jurídica - com liberdade de reconfigurar o Estado, incluindo o Poder Judiciário. Uma Constituição 
não é um código legal escrito por juristas. Soma-se ao fato de que um tribunal que guarda uma Constituição deveria continuar a fazê-lo sempre, mesmo em casos de uma ruptura constitucional, que pode ser declarada como libertadora ou pacificadora (como o era a Constituinte), mas também pode implicar guinadas em direção ao totalitarismo e supressão das liberdades, mesmo sendo difícil imaginar que depois de uma ditadura militar fosse possível escrever uma Constituição mais autoritária do que qualquer ato que a antecedeu.

A Comissão de Estudos Constitucionais, conhecida como Comissão Afonso Arinos (seu presidente), era formada em sua maioria por juristas. Nela estavam Sepúlveda Pertence (à época Procurador-Geral da República e hoje ministro aposentado do STF) e Paulo Brossard (também ministro aposentado do STF). Historicamente as constituições brasileiras começam a partir de um anteprojeto, escrito por uma comissão de notáveis como Afonso Arinos. Em 1987 foi diferente. Embora o ministro Sepúlveda Pertence ${ }^{2}$ tenha me relatado que o projeto teria sido usado como referência, em particular na estruturação do sistema judiciário e do Ministério Público, sabe-se que o anteprojeto formulado pela comissão nem sequer foi oficialmente enviado aos constituintes.

A Assembleia Nacional Constituinte funcionou instituindo 24 subcomissões agrupadas três a três em oito comissões temáticas, cujos projetos seriam unificados por uma comissão de sistematização. Depois de votados nessa comissão, os projetos deveriam ser enviados ao plenário, que poderia aprovar, recusar ou, ainda, emendar as propostas. Os debates acerca da estrutura do Poder Judiciário foram reservados à comissão III, chamada Comissão da Organização dos Poderes e Sistema de Governo, e à subcomissão C: do Poder Judiciário e do Ministério Público. Contudo, propostas relativas ao funcionamento dos tribunais foram apresentadas em diversas outras comissões.

Segundo Koerner e Barros de Freitas (op. cit.), os ministros à época do STF foram importantes agentes na Constituinte, construindo alianças com os parlamentares para

\footnotetext{
${ }^{2}$ Entrevista realizada em outubro de 2012 no escritório de advocacia do ministro
} 
que apoiassem a "preservação do Tribunal". Em nome dessa preservação, conforme os autores, os ministros enunciavam juízos informais acerca das controvérsias políticas, procurando determinar seu sentido jurídico-constitucional e assim orientar a direção do processo político. Falavam então em nome do Tribunal, como juízes. Olhando retrospectivamente, observa-se que futuros ministros da corte participaram do processo de diversas formas. Alguns, como os já mencionados Sepúlveda Pertence e Paulo Brossard, integravam a comissão de notáveis. Outros, como parlamentares, como o ministro Nelson Jobim, que foi deputado constituinte pelo Rio Grande do Sul, e o ministro Maurício Correa, eleito senador nas eleições de 1986 pelo Distrito Federal.

Conforme Koerner e Barros de Freitas (2013) foram apresentadas nas comissões três propostas acerca da estruturação do STF:

Primeiro, a criação do tribunal constitucional ou tribunal das garantias constitucionais, que foi apresentada, discutida e aprovada em subcomissões diferentes com as mesmas linhas gerais: um tribunal autônomo com atribuições exclusivas sobre questões constitucionais, com ministros temporários, ou escolhidos pelo Congresso Nacional, ou pelos três poderes da República. $\mathrm{Na}$ subcomissão do Poder Judiciário e do Ministério Público, o tribunal constitucional foi defendido por Vivaldo Barbosa (PDT/RJ) com base na proposta da OAB. Na subcomissão dos direitos políticos, dos direitos coletivos e das garantias, o tribunal das garantias constitucionais foi proposto pelo relator Lysâneas Maciel (PDT/RJ) com base na ideia de José Paulo Bisol, relator da comissão da soberania e dos direitos e garantias do homem. Uma segunda proposta era a criação no STF de uma seção especializada para conhecer as questões constitucionais, composta por ministros temporários. O STF manteria sua função unificadora da legislação federal, com ministros vitalícios. A proposta foi formulada pelos juízes paulistas da Apamagis e defendida na subcomissão por Michel 
Temer (PMDB/SP) e apoiada pelo presidente José Costa (PMDB/AL). A terceira proposta era a continuidade do STF, que permaneceria como tribunal constitucional, federal e de cassação, com ministros vitalícios. A tese, defendida por Maurício Corrêa (PDT/DF), apoiava os posicionamentos do próprio STF, da AMB (Associação de Magistrados Brasileiros) e do governo (p. 163-164).

A proposta de criar um tribunal ou transformar o STF em um tribunal exclusivamente constitucional tinha como referência o modelo criado pelo jurista austríaco Hans Kelsen. A Corte Constitucional formulada por Kelsen estaria separada do Poder Judiciário e teria por competência a análise de compatibilidade formal de normas e atos do poder público em abstrato. São as chamadas ações de controle concentrado de constitucionalidade. Segundo o ministro Nelson Jobim, em entrevista concedida em 1987 (que consta nos arquivos da Constituinte), a proposta de transformar o STF em um tribunal constitucional objetivava dar ao Supremo força política: "Nós tiraríamos do Supremo aquele volume de trabalho que ele tem, jogaríamos a um outro tribunal e possibilitaríamos que o Supremo fosse, como tribunal constitucional, um grande órgão de força política dentro da nação", disse o ministro.

De acordo Koerner e Barros de Freitas, a posição da maioria dos ministros do STF à época era a de preservar as atribuições do Tribunal, posição sustentada em audiência pública pelos ministros Sydney Sanches e Nery da Silveira. Ainda conforme os autores:

Nas votações da comissão de sistematização tornaram-se mais claros os enfrentamentos políticos acerca da estrutura do STF. Os constituintes de centro-esquerda levantaram dois destaques de emendas. O primeiro, de Nelson Jobim (PMDB/RS), tinha o tribunal constitucional como modelo e propunha alterar a composição do STF para 16 membros, com mandato de oito anos: cinco indicados pelo 
presidente da República; seis pela Câmara Federal e cinco pelo STF. Essas últimas vagas seriam reservadas aos magistrados de carreira. $\mathrm{O}$ autor considerava necessários ministros temporários, dado que o tribunal era responsável pelo controle concentrado e pelo controle difuso de constitucionalidade, enquanto os juízes vitalícios só o exerciam nos países, como os EUA, em que havia apenas o segundo tipo de controle. José Ignácio Ferreira (PMDB/ES) apontou o problema de recolocar os ministros após o fim do mandato, pois não seria razoável que voltassem a instâncias inferiores ou fossem postos em disponibilidade. A emenda foi rejeitada por sessenta votos contra três (p. 163).

As discussões envolvendo o STF e o Poder Judiciário, de modo geral, eram também informadas por um debate público realizado através dos veículos de comunicação, que frequentemente publicavam textos escritos por juristas considerados notáveis, cuja opinião parece ter ganhado importância entre os constituintes. $\mathrm{O}$ editorial do Jornal do Brasil, texto disponível nos arquivos do Senado Federal, de maio de 1987, destacou:

“Eu vou até o Supremo!", é o que costuma dizer o cidadão para fazer valer seus direitos. A frase significa um tributo de confiança na mais alta corte do país, instituição nacional acima de qualquer suspeita que certo espírito leviano, que também faz parte da Constituinte, pretende reduzir a mero Superior Tribunal de Justiça. Para justificar o capitis diminutio, cria-se a Corte Constitucional com membros não vitalícios e mandato de 12 anos. É o que está no relatório da Subcomissão do Poder Judiciário e do Ministério Público. Ainda que implique aprovação final, o que está proposto é a amputação de um sistema pela via da ofensa à história e do menosprezo à nossa cultura jurídica. 
Dos debates em torno da estrutura do STF resultou a manutenção do número de 11 membros com cargos vitalícios, indicados pela Presidência da República. No entanto, condicionou-se tal nomeação à aprovação por ampla maioria no Senado Federal. Garantiu-se ao STF a guarda da Constituição, mas como um tribunal misto com competência ampla. Concedeu-se ainda, ao Judiciário, autonomia funcional e administrativa, emblemas de sua independência.

A Constituição de 1988 faz do Judiciário ponto de unidade entre os três poderes, disse o ministro aposentado do STF Carlos Ayres Brito ${ }^{3}$, e ainda completou: "como todo povo civilizado o faz". O Estado Democrático de Direito celebrado pelo texto constitucional, embora seja um composto de política e direito, garante ao Judiciário um tipo específico de poder com autonomia.

Segundo a cientista política Maria Tereza Sadek (2002; 253-4):

A Constituição de 1988 e os papéis atribuídos ao Judiciário, ao Ministério Público, à Defensoria Pública, à Procuradoria da República, à Advocacia-Geral da União, às polícias, aos advogados, enfim aos operadores do Direito, representam uma mudança radical, não apenas no perfil destas instituições e de seus integrantes, mas também em suas possibilidades de atuação na arena política e de envolvimento com questões públicas. [...] Esse Judiciário, com baixíssima realidade política, ganhou vitalidade na ordem democrática ou, ao menos, foram-lhe propiciadas condições de romper com o encapsulamento em que vinha vivendo desde suas origens. No que se refere às demais instituições do sistema de justiça, a conversão foi ainda maior: conquistaram recursos de poder e um espaço que extrapola (em excesso, diriam alguns) os limites de funções exclusivamente judiciais.

\footnotetext{
${ }^{3}$ Pronunciamento em comemoração aos 25 anos da Constituição de 1988 no STF.
} 
De modo geral, a Constituição promulgada em 1988 aponta para caminhos possíveis em sua interpretação, que nem sempre garantem as intenções do constituinte originário na formulação do texto, mas adaptam-se a cada caso. A apelidada Constituição Cidadã, pelo fato de ampliar os direitos sociais agora alçados à categoria de cláusulas pétreas, é resultado de um processo de disputa entre os poderes constituídos e constituintes, uma disputa que não se esgotou com sua promulgação. No cerne dessas infinitas e redobradas disputas encontra-se o próprio STF, especialmente em querelas acerca de sua estrutura e competência.

A Constituição existiria em potência, como possibilidade do que ainda não se realizou. É nesse sentido que parecem se orientar os discursos comemorativos em torno da Carta Magna de 1988. Ainda que a promessa de futuro apresentada pelo texto constitucional não tenha sido efetivada, como se costuma dizer, existiria, no entanto, um poder constituinte com capacidade para desafiar o poder constituído.

É da própria natureza do direito pressupor tal disputa. Talvez seja por isso que a guarda do texto constitucional é confiada à cúpula do Poder Judiciário e ao seu colegiado de juízes com cargos vitalícios, incumbidos de dizer tecnicamente o que é a Constituição, inclusive sobre si mesmos, implicando em certa medida um tipo de poder constituinte. A Constituição seria uma forma cujo conteúdo não está dado, na medida em que nos limites do Estado o direito, a partir da lei, se produz por meio de interpretações que estão sempre em movimento.

Os debates envolvendo a estruturação do STF apontam para um tribunal inventado por agentes continuam a inventá-lo, não só porque algumas pessoas estiveram dos dois lados do muro (um deputado constituinte ou Procurador da República mais tarde se tornará ministro), mas também porque a cada processo essas pessoas têm o papel de atualizar tecnicamente o modo como o direito o faz.

Se o constituinte originário delegou à Ordem dos Advogados do Brasil papel importante no sistema de justiça, coube ao Supremo reafirmá-lo no julgamento do Recurso Extraordinário que decidiu por unanimidade a constitucionalidade do Exame da Ordem, contra todas as expectativas dos estudantes presentes ao julgamento. 


\subsection{O TRIBUNAL E SUAS COMPETÊNCIAS}

A operação fundamental do Supremo Tribunal Federal parece ser em certa medida a de definir suas competências, seja como sinônimo de poder, seja como obrigaçãodever. Como se respondessem quase todo o tempo a um gabarito de quem pode o quê, baseado em quê. A Constituição Federal delegou ao Supremo duas competências fundamentais: como cúpula do Poder Judiciário, funciona como última instância de todo sistema de justiça; e como tribunal constitucional detém, a "precípua guarda da Constituição”. Desse modo, compete ao Tribunal julgar tanto processos originários que começam e terminam no Supremo - como os recursos - em que o STF pode reverter decisões já proferidas, quando estão de alguma forma relacionadas ao texto constitucional.

Além do que, o tribunal também julga os conflitos de competências de outros tribunais e mais de uma dezena de ações e recursos ${ }^{4}$.

${ }^{4}$ Conforme o texto constitucional cabe ainda ao STF processar e julgar:

- as infrações penais comuns, o Presidente da República, o Vice-Presidente, os membros do Congresso Nacional, seus próprios Ministros e o Procurador-Geral da República;

- litígio entre Estado estrangeiro ou organismo internacional e a União, o Estado, o Distrito Federal ou o Território;

- a extradição solicitada por Estado estrangeiro;

- a revisão criminal e a ação rescisória de seus julgados;

- a reclamação para a preservação de sua competência e garantia da autoridade de suas decisões;

- a execução de sentença nas causas de sua competência originária, facultada a delegação de atribuições para a prática de atos processuais;

- a ação em que todos os membros da magistratura sejam direta ou indiretamente interessados, e aquela em que mais da metade dos membros do tribunal de origem estejam impedidos ou sejam direta ou indiretamente interessados;

- o pedido de medida cautelar das ações diretas de inconstitucionalidade. (grifos no original) 
Esse quadro amplo das chamadas competências - que inclui processos individuais e coletivos, de controle concentrado e difuso de constitucionalidade - faz com que o STF julgue em média 60 mil processos por ano. Em 2006, foram mais de 150 mil processos. A Suprema Corte dos Estados Unidos, por exemplo, julga em média 100 processos durante o calendário forense. A maior parte dos processos recebidos pelo STF (quase 70\%, segundo dados do Tribunal, disponíveis em seus relatórios de atividades anuais) respondem por recursos.

Embora a própria Constituição defina as atribuições da corte, existem diversas leis e emendas constitucionais que dispõem sobre as competências do tribunal, assim como códigos que regulam o processamento de ações e recursos. Desse modo, o STF movimenta suas competências a partir de uma sobreposição de normas hierarquicamente colocadas. Uma norma jurídica, conforme define o jurista Matos, são comandos dirigidos à conduta humana que permitem, proíbem, comandam e definem competências socialmente organizadas e imanentes (2011, p. 47).

A hierarquia entre as normas jurídicas foi pensada pelo normativista Hans Kelsen a partir de um modelo piramidal, em que uma norma só é válida porque está ligada a normas superiores por laços de compatibilidade, em uma cadeia finita que culminaria na norma fundamental. A Constituição, no topo da cadeia do direito interno, seria então pressuposto de validade de qualquer ato normativo abaixo dela, sem, no entanto, ser a norma fundamental em que se ancora todo sistema.

Conforme destaca Nodari (2013), a normal fundamental de Kelsen é:

pressuposta, imaginária, ficcional (para postular o estatuto da norma fundamental, Kelsen se baseou na Filosofia do como se, de Vaihinger, para o qual até mesmo o discurso científico residia, em última instância, sobre alguma ficção). Ou seja, uma maneira de dar validade ao sistema, de remetê-lo ao Um (ainda que alguns queiram ligá-la ao princípio de que os pactos devem ser cumpridos - pacta sunt servanda -, e outros, muito mais tacanhos, à Constituição). 
Teríamos, assim, um sistema de normas com conteúdo baseadas numa norma sem conteúdo e fictícia (p.6).

O direito operaria na relação entre o legal e o ilegal, a partir de requisitos formais de posição, o que transformaria todo sistema jurídico em um sistema circular autorreferente, ou, nas palavras de Luhmann, "o que funda o direito é o próprio direito" (1993, p.15).

A ideia de validade, na leitura de Kelsen, não está ligada necessariamente ao conteúdo das normas como condições de sua existência, mas à sua relação lógica com um sistema posto. Parece ser, nesse sentido, que se dirige a crítica de Carl Schmitt ao normativista, em um dos muitos debates travados entre os dois juristas. Segundo Schmitt, o direito poderia ser em alguma medida um sistema de relações jurídicas, mas como tal não estaria completo. Seria necessário incorporar um "juízo político" na técnica jurídica, levando em conta os atores que o fazem, que aplicam as normas legais. Segundo Annelise Riles, a perspectiva de Schmitt reabre o direito como um conjunto de recursos coletivos e técnicas jurídicas, como se visto a partir da sala de um juiz (2011, p. 45). É o espaço da decisão que parece importar para o autor. O quem decide (SCHMITT: 2006 p. 36). Em última instância, a própria existência do direito estaria condicionada a uma decisão; ele só existe porque uma decisão permitiu sua existência.

No entanto, não me parece que esses circuitos tautológicos ajudem a compreender o modo como, a partir deles, se dão as operações jurídicas. Conforme argumenta Riles (2010) seguindo o jurista francês Yan Thomas, as ficções jurídicas não são uma teoria jurídica, mas uma prática do direito que tem um modo próprio de fazer coisas. O que importa, então, são os movimentos e a replicação desse modo de operação. As ficções não são nada além de ferramentas do conhecimento jurídico, portanto não são boas nem ruins. Não vem ao caso se os juristas acreditam ou não nelas porque o fundamental são suas operacionalizações. 
Independentemente do lugar em que reside sua legitimidade (seja na norma metajurídica de Kelsen, que dá legitimidade formal, seja na "vontade soberana do povo", na qual reside sua validade material), ou de seu caráter intrinsecamente ficcional, parece fundamental saber como essas duas coisas operam, tendo em vista que o direito, se pensado como ciência, tem uma pretensão prescritiva, de intervenção.

Se ao STF foi delegado o poder de proteger a Constituição, o Tribunal o faz a partir de uma série de competências, tanto postas no plano legal, como a partir de uma série de protocolos que devem ser seguidos e que não estão na lei - nem mesmo estão escritos nos documentos jurídicos -, mas que são compatíveis com a própria história do Tribunal e com o modo como ele opera. Cabe aos ministros defender a Constituição como se protege um "templo sagrado", nas palavras do ministro Luiz $\mathrm{Fux}^{5}$, em uma operação que produz resultados muito concretos, embora nem sempre rápidos e automáticos como se poderia esperar.

A guarda da Constituição se dirige, sobretudo, aos poderes Legislativo e Executivo. O primeiro deles, com competência para emendar a Constituição, faz às vezes de constituinte derivado, formulando novas leis que por sua vez devem estar em conformidade com os princípios e comandos constitucionais.

Quando existe dúvida se uma lei tem validade ou não, cabe ao Supremo decidir sua constitucionalidade, mas apenas quando alguém propõe um processo. $\mathrm{O}$ tribunal não tomar a iniciativa apenas atua quando provocado nas formas autorizadas, ou seja, em tipos de processos específicos.

Ainda que possa decidir a validade de normativas ou qualquer ato do poder público em sede recursal, o STF o faz principalmente nas ações originárias do controle concentrado, que podem ser: Ação Declaratória de Constitucionalidade, Ação Direta de Inconstitucionalidade, Arguição de Descumprimento de Preceito Fundamental. Cada uma delas com competências específicas.

\footnotetext{
${ }^{5}$ Entrevista realizada em junho de 2012. STF
} 
A Constituição Federal também delegou aos tribunais que compõe o Poder Judiciário a competência para formular seus próprios regimentos e eleger suas direções. Cabe então ao STF criar seus próprios comandos em termos de procedimentos, tão caros ao universo jurídico. O regimento parece tão importante que a ele se dirige um tipo específico de recurso, os chamados agravos regimentais.

O regimento interno do STF (RISTF) “estabelece a composição e a competência dos órgãos do Supremo Tribunal Federal, regula o processo e o julgamento dos feitos que lhe são atribuídos pela Constituição da República e a disciplina dos seus serviços" (RISTF, Disposições Gerais). Foi editado originariamente em 1980 e vigora até os dias de hoje, com 48 emendas. Sua eficácia foi recentemente alvo de debate na corte nos recursos da Ação Penal 470, conhecida como mensalão. O debate envolvia o status do regimento que, mesmo anterior à Carta Magna, foi recepcionado por ela. A ideia de recepção evidencia o fato de que uma nova Constituição não renova tudo, pois o futuro ao qual a Constituição remete é também um passado. Leis anteriores a ela continuam a vigorar, embora submetidas aos princípios e disposições da nova ordem. Esse é o caso do código penal, por exemplo, que é de 1940.

A posição vencedora no julgamento do recurso citado confirma o regimento interno com status de lei, ou seja, tem a mesma força de comando que uma lei ordinária formulada pelo legislador. O regimento parece ser uma versão do Tribunal para todos os comandos dados pela Constituição, pelas leis e pelos códigos, repetindo-os muitas vezes textualmente, sem precisar reformulá-los inteiramente. Em suma, adaptando-se às novas regras. $\mathrm{O}$ regimento interno reverbera sobre si mesmo quando destaca que o Tribunal, mesmo com mudanças em suas competências, mantém sua forma e seu modo de operação.

\subsection{OS LUGARES DO TRIBUNAL}

A organização física e a estética arquitetônica do STF não apenas compõe um cenário onde tudo se passa, como parecem relevantes na própria constituição da produção 
jurídica no STF. Como já foi destacado por Douglas, Sarat e Umphrey (2003), é certamente muito difícil pensar no Direito sem alguma associação com o lugar em que ele é operado, sejam tribunais ou delegacias. Conforme os autores, o conceito de lugar do direito (the place of law) implica uma reflexão acerca de um território específico, acerca dos limites do universo legal, ou seja, o que está dentro e o que está fora de sua jurisdição.

As descrições dos lugares do direito parecem desempenhar um papel central na análise sociojurídica dos processos de tomada de decisão. A exemplo de Garapon (1997), que apresenta a arquitetura dos espaços judiciais na França, organizada em torno das noções de distância, neutralidade das formas, separação, simetria e ordem.

Apesar da estética modernista dos prédios do STF, o interior dos edifícios possui uma decoração contrastante, e me parece ser o mobiliário que ajuda a fortalecer a ideia de autoridade e nobreza do tribunal. No site do supremo, em seção dedicada a apresentar o espaço do tribunal, consta uma declaração em destaque, sem data, do arquiteto Oscar Niemayer, a respeito da obra do STF:

A singeleza do projeto e as proporções relativamente reduzidas deste edifício não impediram que o partido adotado lhes conferisse as características de dignidade e nobreza reclamadas, características essas que as galerias externas acentuavam convenientemente.

A “nobreza" do Tribunal está também, e, sobretudo, nos tapetes, nos quadros espalhados pelas paredes - com molduras em dourado envelhecido, nos bustos de cobre colocados no hall de entrada do prédio principal, nas mesas de madeira nobre ocupadas pelos ministros, nos retratos em preto e branco dos ministros de "hoje" e "de sempre" pendurados na parede do salão branco, localizado atrás do salão do plenário. Nomear as salas oficialmente, como salão branco, ou hall dos bustos, me parece também uma forma de garantir que esses lugares não são comuns, como qualquer outra sala anônima ou identificada pelas operações nela executadas. As salas 
nomeadas e decoradas com objetos antigos, quase que naturalmente impõem ao visitante um tipo de comportamento. Quando passava por esses lugares percebia que as pessoas abaixavam o tom de voz, andavam mais lentamente, pareciam reverenciar o lugar.

Em sua reflexão sobre tempo e espaço, o filósofo Casey (1996) afirma que os lugares mantêm coisas, mas mantêm, sobretudo, uma experiência encarnada de estar no lugar. Argumenta o autor, que lugares não são apenas, mas, sobretudo acontecem. Exatamente porque acontece o espaço do Tribunal não é estático, pois ele também se transforma.

Essa experiência de estar no Tribunal é vivenciada por aqueles que o visitam, a partir de lugares pré-selecionados, que são justamente os lugares nomeados. Os visitantes não são levados a conhecer as salas com mesas simples e coloridas com centenas de processos espalhados pelo chão, embora essas salas façam parte da composição do Tribunal e da experiência daqueles que produzem cotidianamente o STF. A visita ao Tribunal que proponho nesta tese inclui esses espaços, que também acontecem e são animados por um conjunto de relações (Reed, 2004) e transformações.

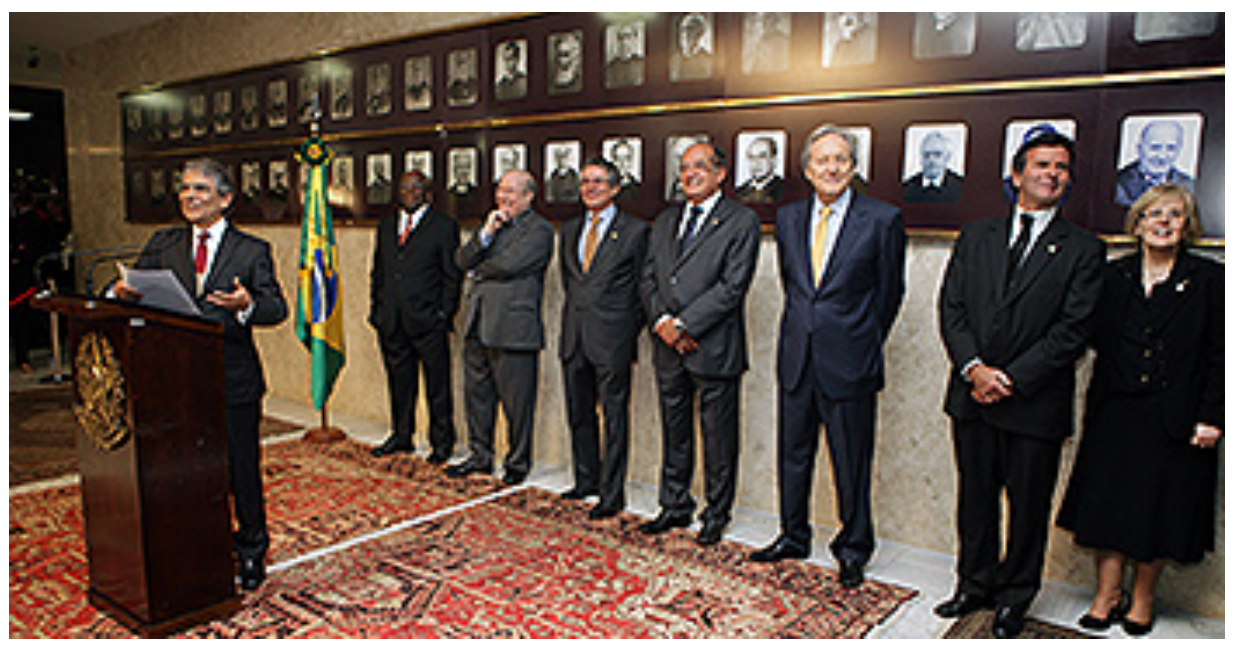

Figura 1 - Salão Branco. Solenidade em que o retrato do ministro Ayres Brito passou a ocupar a galeria dos ex-presidentes. Fonte: STF 
De acordo com o Regimento Interno do Supremo (RISTF), são órgãos do Tribunal: o pleno, as turmas e o presidente. Esses órgãos têm suas competências reguladas pelo próprio regimento. Embora definidas no texto, que endereça a cada órgão tipos ou classes de processos, os objetivos ou mesmo quem figura em cada processo atraem competências de órgãos diferentes. Cada um desses órgãos ocupa partes distintas dos prédios do Tribunal. O pleno e o gabinete do presidente ficam no prédio principal, chamado de sede, com três andares e um subsolo. No primeiro andar, o grande salão do pleno; no segundo, o gabinete do presidente. Os setores ligados diretamente à presidência também ocupam o prédio central. A sala em que trabalha o presidente é um espaço grande com duas mesas: uma grande para reuniões, e a mesa do ministro, além de alguns sofás para receber convidados, dispostos próximo às grandes janelas. Ainda existe uma grande estante repleta de livros.

Parte do mobiliário da presidência foi trazida das antigas instalações do Tribunal no Rio de Janeiro, com a ordem do presidente do STF em 2011. São mesas, poltronas, escrivaninhas imperiais, de madeira escura, todas talhadas. E aqui cabe um parêntese. Pelo menos a partir de 2003 os ministros têm falado cada vez mais de um novo tribunal. O marco cronológico é a aposentadoria do último ministro indicado pelo governo militar, Moreira Alves. Após a aposentadoria desse ministro, o STF teria passado a ocupar o lugar que a Constituição supostamente lhe reservara, de maior intervenção no processo político e social do país. Desde a saída de Moreira Alves, o Tribunal assumiu outra posição no desenho republicano, reinterpretando suas competências constitucionais e reinventando outro lugar para si mesmo. Todavia, seria injusto colocar no centro do novo tribunal, apenas os novos ministros. O Tribunal muda à medida que os processos que circulam por ele permitem reorientações e a doutrina jurídica avança suas ferramentas analíticas. O novo tribunal transforma também o lugar e as relações no interior da instituição. Conforme os funcionários mais antigos do STF com quem conversei, os "juízes agora se dão mais importância". O antes seria menos formal, com uma proximidade maior entre os ministros e os funcionários que trabalhavam mais próximos, no anexo I, prédio muito menor, localizado logo atrás da sede. Neste anexo ficavam quase todos os setores do Tribunal, inclusive os gabinetes dos ministros, que eram menores. A construção do novo anexo, também obra de Oscar Niemeyer, marca uma separação; a partir daquele 
momento os gabinetes ficam mais isolados do restante dos setores, assim como os ministros.

O prédio do anexo II localiza-se ao lado da sede e se divide em dois prédios conectados. A organização dos prédios lembra um labirinto, cheio de corredores que levam a setores diferentes, que aos incautos parecem escondidos. Particularmente, depois de frequentar o prédio durante quase dois anos, ainda não ando por ele com facilidade, sempre preciso de ajuda para encontrar os departamentos ou gabinetes de destino. Estar perdida no prédio, em alguns momentos, permitiu- me deparar com lugares nos quais pessoas que não são funcionárias do Tribunal não podem chegar; salas e departamentos cujas funções são quase imperceptíveis.

Os prédios também parecem esconder os lugares por onde passam os ministros, que não costumam dividir as passagens com os outros funcionários, como se para eles existissem passagens secretas e elevadores privativos. A organização arquitetônica do STF parece seguir um modelo dos prédios reservados a tribunais. Em sua tese de doutoramento, Maria Gabriela Lugones (2009) também descreve as disposições dos setores do Palácio de Justiça em Córdoba, analisando a organização de suas plantas, que faz com que a localização de gabinetes e escritórios seja difícil (LUGONES, p. 72).

Poucas pessoas circulam pelos corredores do tribunal. Na maioria das vezes apenas funcionários, identificados por crachás. No andares dos gabinetes a circulação é ainda menor. As pessoas comuns - não funcionários e não advogados - não costumam entrar no prédio. $\mathrm{O}$ acesso do Tribunal às pessoas comuns está ou nos processos, ou nos espaços públicos como o plenário e as turmas. Embora não existam regras que restrinjam a mobilidade de pessoas no prédio (à exceção dos gabinetes, em que não se pode entrar sem autorização), ninguém entra nele sem uma razão muito específica relacionada aos processos. As portarias dos três prédios exigem a identificação das pessoas e o motivo da entrada. Com essas informações os funcionários entregam ao visitante um crachá, que limita o acesso a qualquer outro lugar que não àquele informado. Certamente existem razões de segurança que envolvem o acesso ao Tribunal, mas me parece mais do que isso. Existe uma noção de separação que opera nos acessos restritos. Ao mesmo tempo em que o Tribunal cria diversos instrumentos 
que possibilitam uma maior aproximação dele com o mundo exterior - como é o caso das audiências públicas, da transmissão dos julgamentos pela TV e pela Web -, existe um lugar próprio para que isso aconteça, e ainda assim seria preciso manter dele certa distância.

Nos corredores do terceiro e do quarto andar, ficam os gabinetes dos ministros. Os corredores são fechados por portas de madeira. Os ministros dispõem de algumas salas ao longo desses corredores, que têm paredes de madeira e muitas portas. Cada gabinete tem uma disposição própria, e as paredes de fácil remoção permitem que cada novo ministro ajuste seu gabinete de acordo com sua vontade. Existe um departamento de arquitetura no Tribunal que executa e auxilia os ministros em possíveis mudanças que queiram realizar.

Embora diferentes, o costume é que os gabinetes reservem uma das salas ao ministro, que normalmente é mais afastada das outras em que trabalham seus assessores. É também comum que reservem uma das salas como porta de entrada tanto de processos como de pessoas. A própria organização das salas nos gabinetes permite saber quem são os funcionários de maior confiança - esses últimos com suas salas cada vez mais afastadas da entrada e mais próximas aos ministros. Na sala dos ministros, em regra, existem coleções de livros dispostos em estantes abertas, e um mobiliário diferenciado. Alguns também exibem seus diplomas e certificados na parede.

Pelo regimento interno, cada gabinete tem um chefe, bacharel em direito, cinco assessores também com formação em direito, dois assistentes judiciários com formação superior, além do quadro de funcionários comissionados, dos quais no mínimo três devem ser funcionários do Tribunal. Além desses, existem funcionários terceirizados que realizam algumas tarefas sem previsão regimental.

\subsection{AS TURMAS RECURSAIS E AS SECRETARIAS}

As denominadas turmas recursais do Supremo são formadas por cinco ministros, entre 
eles um presidente, eleito pela própria turma por ordem de antiguidade. A essa instância cabe o julgamento de recursos em questões tidas como comuns, aquelas que não têm previsão de quórum qualificado ou especial. Ou seja, não precisam ser julgadas pelo corpo de ministros. A ela são endereçados, por exemplo: o habeas corpus, os incidentes de execução, reclamação e agravo regimental. Essas classes de processo pedem à corte que exerça sua força revisora, podendo reverter decisões proferidas por outros tribunais, ou mesmo pelos próprios ministros da Corte. Todavia, se o paciente de um habeas corpus figurar na lista das autoridades com prerrogativa de foro, ele deve ser julgado pelo pleno.

As turmas se reúnem no anexo II, setor B, também chamado de capela. Suas seções são abertas ao público, que se senta em frente à bancada de ministros, em forma de meia-lua. O presidente da turma senta-se no meio, ficando o Procurador-Geral da República ou seus representantes à sua direita. Os demais ministros sentam-se em ordem decrescente de antiguidade, alternadamente nas poltronas laterais, começando pela direita. Esses julgamentos acontecem ordinariamente às terças-feiras à tarde $\mathrm{e}$ costumam ser mais rápidos que os julgamentos do pleno, sem grandes intervenções dos ministros presentes. É recorrente que os ministros apresentem listas compostas de vários processos da mesma classe, para serem decididos em conjunto. 


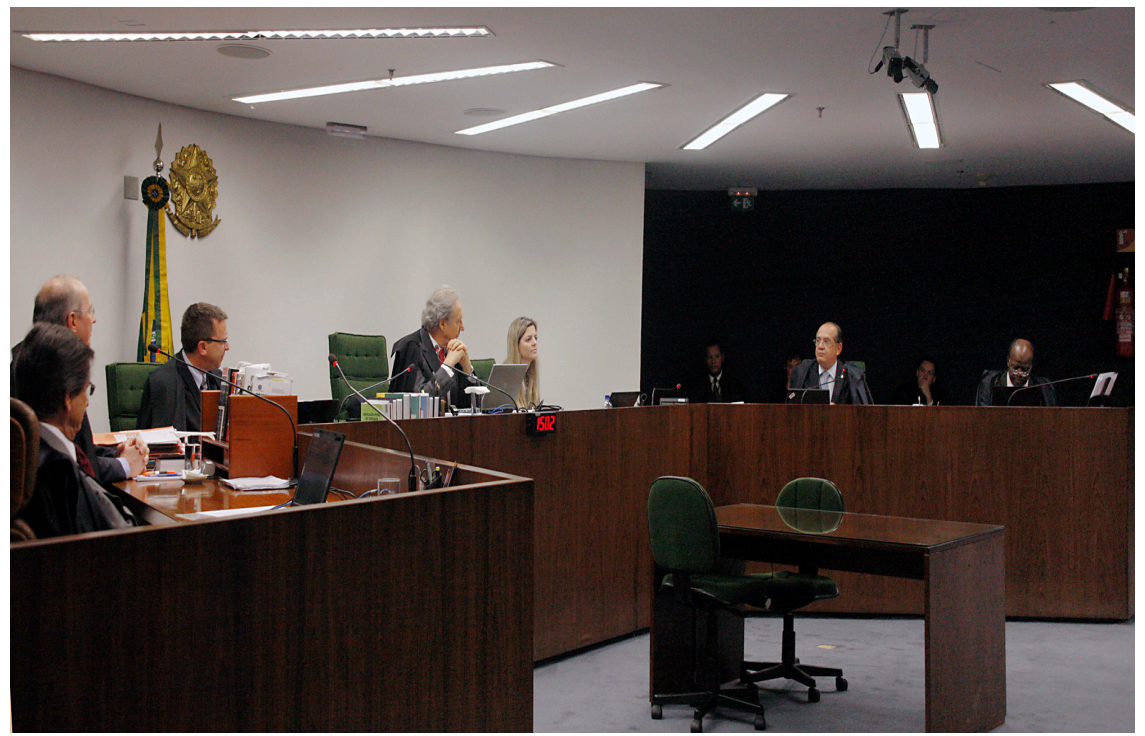

Figura 2 - Segunda Turma Recursal em sessão de julgamento. Foto Arquivo STF.

No auxílio dos trabalhos das turmas existe uma coordenadoria para cada uma delas, responsável por dar encaminhamento às decisões e por secretariar o julgamento. Essa coordenação compõe a chamada Assessoria das Sessões, que recebe os autos com pedido de data para julgamento, organiza a pauta, faz a ata e transcreve os votos declarados em documentos que irão compor os processos. Ela é também responsável pela administração dos chamados acórdãos - documentos que oficializam as decisões colegiadas dos ministros, tanto nas turmas como no pleno.

O processo de composição do documento decisório começa com as transcrições dos vídeos gravados durante o julgamento, que serão encaminhadas aos ministros para que as confiram. Depois serão publicadas no Diário da Justiça - canal oficial de publicação dos julgados.

A secretaria das sessões também auxilia os trabalhos do pleno, que reúne os 11 ministros do Tribunal. Cabe a essa instância julgar, sobretudo, as chamadas matérias constitucionais do controle concentrado. Cabe ainda ao pleno julgar processos criminais em Ação Penal Originária que envolvam pessoas detentoras de cargos públicos com a chamada prerrogativa de foro, que são, entre outros, o Presidente da República e seus ministros, senadores e deputados, além do Procurador-Geral da 
República. É ainda atribuição do pleno eleger, entre seus ministros, os que devam compor o Tribunal Superior Eleitoral - instância da chamada justiça especializada. O STF tem direito a três vagas no TSE. A esses é reservada a presidência do tribunal eleitoral.

As quartas e quintas-feiras, o pleno se reúne em sessão ordinária transmitida ao vivo pelo sistema de televisão do STF, a chamada TV Justiça ${ }^{6}$.

O presidente do Tribunal é eleito pelo colegiado de ministros por meio de voto secreto. No entanto, tradicionalmente não existe de fato uma disputa. Assume a presidência o ministro mais antigo que não tenha ainda ocupado o cargo. É uma eleição simbólica, embora essa tradição não esteja incorporada ao regimento, que inclusive prevê uma espécie de segundo turno caso os candidatos não consigam alcançar maioria absoluta. Conforme o ministro Sydney Sanches (Trecho do pronunciamento datado de 1989 homenageando o ministro Nery da Silveira que

${ }^{6}$ Esse canal de transmissão das sessões de julgamento do STF foi criado por um ministro da corte, Marco Aurélio Mello, quando assumiu interinamente a presidência da República. Sendo o terceiro na linha sucessória, o ministro ocupou por cinco vezes o cargo, e em maio de 2002 sancionou a Lei ${ }^{\circ}$ 10.461, que criou a TV Justiça, instrumento não consensual entre os ministros da corte. A própria Constituição Federal já afirma que os julgamentos da Suprema Corte são públicos em seu artigo 93, inciso IX: "todos os julgamentos dos órgãos do Poder Judiciário serão públicos", "podendo a lei limitar a presença, em determinados atos, às próprias partes e a seus advogados, ou somente a estes, em casos nos quais a preservação do direito à intimidade do interessado no sigilo não prejudique o interesse público à informação". A partir de 2002, além de públicos no sentido de que qualquer pessoa trajada devidamente - terno e gravata para homens, e vestidos de mangas, tailleurs ou ternos (calça e blazer de manga comprida), para mulheres -, pode assistir às sessões estando no STF -, eles também são transmitidos em canal aberto de televisão, coordenado pelo próprio Supremo, e via rádio Justiça, de alcance nacional. Tanto a TV quando o rádio são tidos como emblemas da ideia de transparência e aproximação. Têm ao mesmo tempo um caráter pedagógico de esclarecimentos de direitos e garantias normativas. Compete a uma coordenadoria específica do Tribunal o gerenciamento dos veículos de comunicação, subordinada diretamente à presidência. 
acabará de assumir a presidência do tribunal, disponível no acervo histórico do tribunal), as eleições do STF acontecem "sem traumas, sem alarde, sem o estrépito e o alarido dos grandes eventos políticos".

A cada dois anos a eleição se realiza, tendo o futuro ministro presidente dez dos 11 votos possíveis - quando a corte está completa. O candidato não vota nele mesmo, costumando dar seu voto ao seu vice, já que são eleições separadas. O vicepresidente é eleito dessa mesma forma, e será ele o próximo presidente, seguindo a tradição.

Mesmo tendo uma eleição proforma, a posse de um novo presidente é certamente o momento mais solene do Supremo. Embora a eleição ocorra de fato sem alarde, a posse de um presidente da corte movimenta a agenda pública do Tribunal em uma solenidade que reúne os chefes dos três poderes da República, além de políticos e de uma parcela da elite jurídica nacional.

Ainda que não esteja acima dos ministros nos encaminhamentos de direito, cabe ao presidente à gerência das questões administrativas do Tribunal, bem como representar o Tribunal diante dos demais poderes da República, além de dirigir os trabalhos do pleno. A presidência detém um tipo especifico de poder dentro do Supremo. Ao presidente é atribuída uma ampla liberdade para pautar o tribunal. Define, portanto, quais serão os processos julgados a cada semana. Embora não possa parecer um grande feito, a formulação da pauta - como pretendo demonstrar mais adiante compõe os resultados dos julgamentos.

A rotina administrativa do Tribunal não parece estar completamente afastada da lógica que rege as rotinas processuais. Embora o presidente tenha ampla liberdade no que se refere à administração do Tribunal, através de duas secretarias: SecretariaGeral da Presidência e a Secretaria do Tribunal, os demais ministros participam em alguma medida das deliberações administrativas e da gestão da instituição. Além dos espaços de decisão que os reúne, os ministros compõem comissões permanentes com temas específicos, como a Comissão de Regimento, de Jurisprudência, de Coordenação e de Documentação. Tais comissões são constituídas por meio de Portarias assinadas pelo presidente. 
Embora essas comissões tenham autonomia em seus encaminhamentos, podem fazer propostas relativas às rotinas do Tribunal nas chamadas sessões administrativas. Essas sessões são previstas no regimento como as únicas secretas; nelas é apenas admitida a presença dos ministros e do diretor-geral do Tribunal, e o conteúdo não precisa ser publicado (embora o seja na maioria das vezes). Nessas sessões os ministros gerenciam o Tribunal, aprovam seu orçamento, decidem quais serão os indicados para compor o Conselho Nacional de Justiça $^{7}$ e acerca das questões trabalhistas dos funcionários do STF (transformadas também em processos com numeração, assim como são transformadas em processos as mudanças na estrutura orgânica do Tribunal).

Também nas sessões administrativas os ministros acompanham e aprovam projetos de lei que serão enviados ao Legislativo, como previsto no texto constitucional, assim como são consultados sobre projetos que estão em andamento no Congresso Nacional, relacionados ao Poder Judiciário. As deliberações dessas sessões são publicadas em Atos Administrativos, assinados pelo presidente, sendo também publicadas no diário da justiça (quando dizem respeito a mudanças no regimento).

Por toda a estrutura administrativa relacionada aos processos no Tribunal responde a Secretaria-Geral da Presidência e o seu secretário-geral. SG tem regulamento próprio, que pode ser alterado através de atos regulamentares, aprovados nas sessões administrativas. Além dela, existe uma Secretaria do Tribunal, relacionada à gestão de pessoas e às demandas dos funcionários, gestada pelo Diretor-Geral do Tribunal. A Secretaria-Geral (SG) é composta por assessorias que se relacionam diretamente à presidência e suas demandas de gestão, como Secretaria de Assuntos Estratégicos, Cerimonial e de Assuntos Internacionais, entre outras, mas também por secretarias responsáveis por encaminhamentos de direito, atuando na gestão e circulação de processos.

${ }^{7}$ O Conselho Nacional de Justiça é órgão externo ao Poder Judiciário, embora presidido pelo presidente do STF. Atua no controle de atuação administrativa e financeira do Poder Judiciário, além de controlar o cumprimento dos deveres funcionais dos juízes. O STF pode indicar dois dos conselheiros, sendo um desembargador federal e um juiz estadual. 
O Diretor-Geral tem por atribuição disciplinar o Tribunal através da edição de Instruções Normativas, assim como ao secretário-geral cabe uniformizar os atos por meio dos chamados procedimentos judiciais. Todos esses documentos, como portarias, atos administrativos e regulamentares e procedimentos judiciais, ao mesmo tempo que são internos ao Tribunal, também podem ter seus efeitos externos ao STF, tendo em vista que regulam procedimentos que deverão interferir na forma como são processadas as ações ou recursos endereçados à corte. A competência para assinar um desses tipos de documentos é concedida a funcionários de confiança do presidente, indicados ${ }^{8}$ e nomeados por ele. Tais funcionários do primeiro escalão do Tribunal se constituem como autoridades, sendo subordinados ao presidente e também aos ministros. Na hierarquia do STF, todos os lugares em que existem ministros atuando têm equivalência e estão acima de todos os outros.

As assinaturas fazem parte da cadeia de comando do Tribunal, pois um texto escrito só se transforma em documento quando assinado. No regimento se explicita quem pode assinar qual tipo de documento, assim como quais são as atribuições delegadas

${ }^{8}$ Segundo Pedro, funcionário analista judiciário do STF, os cargos do segundo escalão também eram indicações do presidente, embora houvesse uma convenção interna de que só seriam mudados caso houvesse interesse dos ministros. Contudo, às vésperas da eleição do ministro Marco Aurélio Mello para presidente em 2001, corriam boatos de que o ministro demitiria todos os funcionários aposentados lotados nos gabinetes, o que não agradou aos demais ministros, em especial Moreira Alves, tido como uma grande liderança do Tribunal - além de ser mais antigo que o ministro Marco Aurélio. Os funcionários mais antigos do Supremo mantinham relações muito próximas aos ministros. E, nesse caso específico, estava envolvido um médico do Tribunal que seria demitido. Com a notícia das demissões, conta Pedro, uma grande parte dos aposentados apresentou sua carta de demissão, o que incluía o médico. Porém, a atitude do ministro Marco Aurélio não passou impune. Reunidos em sessão administrativa, os ministros aprovaram uma mudança regimental, retirando do presidente a prerrogativa de indicar livremente o segundo escalão, condicionando essas indicações à aprovação do colegiado. Segundo o funcionário, os ministros, antes das sessões, se reuniram no apartamento de um deles para resolver a questão. 
pelo tribunal a alguns de seus servidores. Por exemplo, o presidente deve assinar as correspondências destinadas ao "Presidente da República; ao Vice-Presidente da República; ao Presidente do Senado Federal; aos Presidentes dos Tribunais Superiores".

Ainda compõem a Secretaria-Geral da Presidência duas secretarias, que gerenciam diretamente os processos sob aspectos diferentes: a chamada Secretaria Judiciária (SEJ) e a Secretaria de Documentação, dois setores especializados, que embora subordinados à presidência, atuam em conjunto com os gabinetes dos ministros nos encaminhamentos de direito de cada processo. A Secretaria Judiciária dispõe de várias salas no segundo andar do prédio Anexo II, cada uma delas com diversas baias azuis com computadores e, nas paredes, grandes armários e estantes onde ficam os processos.

Ela está dividida em diversos setores por onde circulam todos os autos em curso no Tribunal. É a SEJ que recebe os processos, ou as petições iniciais - como são chamados os documentos que inauguram processos - e os encaminha para os gabinetes, assim como tem por competência encaminhar todos os atos realizados pelos ministros nos processos.

Atualmente, a Secretaria Judiciária é composta por 489 pessoas, entre funcionários e estagiários. Um número que aumenta muito se consideram na sua composição os processos que estão na secretaria ou que circulam por ela. O padrão é que se receba em média 300 processos por dia. Como está subordinada à presidência, cabe a essa instância o controle de suas funções, podendo alterar sua composição operacional por meio de Atos Regulamentares.

A última grande alteração na SEJ aconteceu em 2010, e foi feita com o objetivo de adaptar seus setores para o uso de meios tecnológicos na tramitação processual. $O$ Tribunal criou um sistema chamando e-STF; este permite que a entrega de documentos que compõem os autos seja realizada através da internet, e que sejam processados por meio eletrônico. O uso da tecnologia criou instrumentos que possibilitam um trâmite dos processos diferenciado. Permite maior celeridade nas decisões da repercussão geral descrita no início, por meio do plenário virtual, em os 
ministros podem simultaneamente ver o processo e decidir. Por meio eletrônico, um ministro é notificado dos processos sob sua responsabilidade e pode decidir, sem a necessidade que esteja presente no Tribunal.

Além de um ambiente de rede eletrônico à disposição pela internet, existe um sistema de intranet nos gabinetes. Entre os recursos desse sistema estão os sistemas e-gabinete e o e-decisão. O primeiro é responsável pelas informações de onde e com quem está cada processo, e o segundo contém minutas do relatório e das decisões de cada caso. Pelo e-decisão um ministro pode assinar eletronicamente a decisão de um processo ou de vários de uma só vez.

As estruturações da Secretaria Judiciária são realizadas com o objetivo de dar celeridade aos processos, como emblema da modernização do sistema de justiça. A cada relatório de gestão publicado pelos presidentes do Tribunal, a diminuição do número de processos e uma maior rapidez em seus julgamentos são ostentados como conquistas de todo o sistema. Desse modo, cada presidente em conjunto com os ministros busca criar mais e mais filtros para restringir a tramitação de recursos endereçados à corte. O ideal dos ministros é transformar o STF em uma Corte exclusivamente constitucional, como era proposta vencida na Assembleia Nacional Constituinte. Tal projeto se assemelha aos votos vencidos dos ministros, pois em ambos os casos, uma posição sempre pode renascer das cinzas e retornar como posição vencedora.

\subsection{COMO SE FAZ UM MINISTRO}

Um tapete vermelho foi estendido na entrada do STF. Sobre ele, uma marquise foi montada formando uma passarela que dá acesso à primeira sala do Tribunal, o salão dos bustos. Ao passar pela passarela, os convidados foram recepcionados pelos dragões da Independência, em pé, com suas espadas em punho. Estamos no dia 4 de março de 2011, na cerimônia de posse do excelentíssimo ministro Luiz Fux. Nesse dia, muitos carros oficiais estavam estacionados à porta do Tribunal. Além dos 
convidados pessoais dos ministros - sua família e amigos - muitas autoridades foram convidadas; entre elas, a própria Presidente da República, chefe do Poder Executivo, os presidentes da Câmara dos Deputados e do Senado Federal, assim como ministros de Estado e juízes dos mais diversos tribunais brasileiros.

$\mathrm{Na}$ entrada, vários funcionários do $\mathrm{STF}$ recebem os convidados entregando-lhes broches coloridos que identificam em qual setor do plenário poderão se sentar, de acordo com a divisão realizada pela secretaria de cerimonial - responsável por organizar a sessão solene. Do lado de fora três telões foram instalados, permitindo que os jornalistas e o público em geral pudessem assistir à sessão em tempo real.

No interior do salão do plenário, no tablado mais alto, ao lado direito da cadeira do presidente do STF, estava sentado o presidente do Congresso Nacional, senhor José Sarney, ao seu lado o procurador-geral de República, na época Dr. Roberto Gurgel. À esquerda estavam o presidente da Câmara, Marco Maia, e o secretário do plenário.

Poucos minutos das 16 horas haviam se passado, quando tocou o sinal avisando que os ministros estavam prontos para entrar. Os convidados ficaram em pé para receber os juízes, que entraram no plenário liderados pelo presidente, na época ministro Cezar Peluso, e seguindo a ordem de antiguidade. Vestindo seus trajes especiais, os ministros se posicionaram em frente as suas bancadas, dispostas em formato de $\mathrm{U}$.

Depois de autorizados pelo presidente, todos se sentaram. Cezar Peluso declara então aberta a sessão solene de posse e convida todos a ouvir o hino nacional, nesse dia tocado pela banda dos fuzileiros navais de Brasília. Até esse momento o novo ministro não estava no plenário. Entra depois de ser ouvido o hino, trazido pelo ministro decano e pelo ministro mais novo. Posiciona-se em frente ao púlpito, para realizar o juramento: "Prometo, bem e fielmente, cumprir os deveres do cargo de ministro do Supremo Tribunal Federal, em conformidade com a Constituição e as leis da República". O secretário da sessão lê o termo de posse e o assina, assim como os demais ministros e o procurador-geral da República. Nesse momento o que se ouve são os flashes das câmeras, seguidos de aplausos da plateia. O presidente então declarou empossado o novo ministro, convidando-o a ocupar o seu lugar na bancada, gesto esse que provocou mais aplausos da plateia. No caminho até sua nova cadeira, o 
ministro cumprimenta seus colegas e, além deles, os ministros de sempre - como são chamados os ministros aposentados. Uma vez ministro, sempre ministro - é um título que não se perde mesmo depois de não se estar mais em atividade no STF, ou até mesmo de estar exercendo a advocacia.

Já empossado, o novo ministro se senta com os demais. O ministro presidente toma a palavra para fazer os formais agradecimentos, sempre a alguém, em nome de quem cumprimenta outros da mesma categoria. Cumprimenta o ministro da Justiça José Eduardo Cardoso, e em seu nome os demais ministros de Estado; o presidente do Superior Tribunal do Trabalho, em nome de quem cumprimenta todos os membros da Justiça do Trabalho; o Governador do Estado do Rio de Janeiro, em nome de quem cumprimenta todos os governadores presentes; o presidente da Ordem dos Advogados do Brasil, em nome de quem cumprimenta todos os advogados presentes, e assim o faz citando todos os presidentes de tribunais superiores e militar, e demais setores. Por pelo menos cinco minutos se ouvem os cumprimentos, o que significa dizer que não eram poucas as autoridades cujos nomes mereceram ser citados, assim como não eram poucas aquelas cumprimentadas em nome de alguém. De fato, reunida naquele plenário estava uma grande parte da elite jurídica do país, prestigiando a posse de um de seus membros ao disputado cargo de ministro da mais alta corte.

O termo disputado foi usado exatamente para demonstrar que a nomeação de um ministro do STF se dá a partir de uma disputa, não oficial, não pública, sem regras claras, mas com direito a campanha, apoios, reuniões, e, por fim, votos - o que para alguns é apenas uma formalidade.

Os comandos constitucionais para a escolha de um ministro do STF estão no artigo 101, que declara que o Supremo Tribunal se compõe de 11 ministros, entre os cidadãos com mais de 35 anos e menos de 65 e que possuam notório saber jurídico e reputação ilibada. São escolhidos pelo presidente da República e aprovados pelo Senado Federal. Note-se que não existe obrigação legal de que a escolha se dê apenas entre bacharéis em direito, porém em toda a história da Corte em apenas um caso se registrou a escolha de um médico como ministro. Este foi Candido Barata Ribeiro, que pouco tempo depois de empossado por decreto em 1893, teve sua nomeação cassada pelo Senado pela falta do requisito notável saber jurídico. 
Mas de que forma se dá essa escolha para tão prestigiado cargo?

Depois de empossados, poucos ministros comentam o processo pelo qual passaram até sua indicação. Alguns falam da surpresa por terem seus nomes avaliados pelo presidente da República em exercício, e na honra por serem escolhidos. Ao que tudo indica juízes ou advogados que manifestam a vontade de assumir o cargo de ministro do STF fazem mais do que construir seus currículos e se preparar para, quando eventualmente seu notório saber for reconhecido, ser chamados a cumprir a "missão" de julgar, sentados nas poltronas da Suprema Corte.

A indicação de um ministro é sem dúvida uma escolha política. Se isso explicasse qualquer coisa poderíamos parar por aqui, o que certamente não é o caso. É uma escolha política, tendo em vista a importância do cargo e as possíveis implicações políticas das decisões da corte. Embora juntar política e direito na mesma frase possa soar aos ouvidos dos ministros do Tribunal como uma acusação, não é disso que se trata, pelo contrário. Não estamos nos referindo aqui a um fenômeno conhecido como judicialização da política - que se refere a um envolvimento do Poder Judiciário em questões a princípio entendidas como da alçada dos poderes Legislativo e Executivo - , mas a um tipo de política que está na natureza do próprio poder jurisdicional.

Ao que parece, fazer direito, ou operar o direito, ou até mesmo fabricar o direito (para usar o termo de Latour, 2010) não é simplesmente conectar as leis aos fatos. Essa operação pressupõe uma transformação tanto da lei como dos fatos e cada vez mais as decisões tem consequências no mundo da política. Como escreveu o hoje ministro Luís Roberto Barroso (2013):

Direito é política no sentido de que (i) sua criação é produto da vontade da maioria, que se manifesta na Constituição e nas leis; (ii) sua aplicação não é dissociada da realidade política, dos efeitos que produz no meio social e dos sentimentos e expectativas dos cidadãos; (iii) juízes não são seres sem memória e sem desejos, libertos do próprio inconsciente e de qualquer ideologia e, consequentemente, 
sua subjetividade há de interferir com os juízos de valor que formula. Mas evidentemente, Direito não é política no sentido de admitir escolhas livres, tendenciosas ou partidarizadas. (sp)

Nos termos de Latour (2010), Direito é também política, ou pelo menos pode ser confundido facilmente com esta. E nesse sentido é Direito, assim, com letra maiúscula, como instituição. E, como instituição, é um composto de ingredientes indefinidamente misturados, que engloba a totalidade de textos, de atos e de instituições - como o STF, por exemplo. Esses elementos todos estão conectados de um modo específico - um modo de enunciação extraído da instituição. Assim é direito, com um modo específico de produção de verdade, com condições de possibilidade singulares. Nesse sentido, direito não é política.

Segundo Alain Pottage (2012), os regimes de enunciação se desenvolvem de acordo com princípios de uma engenharia discursiva que unem as coisas tais como declarações, atos de fala e textos. Desse modo, o direito é definido a partir de um "marcador que qualifica determinados enunciados como um elemento de Direito e não de algum outro modo de existência" (p. 170). A relação entre instituição e modo de enunciação está, no exemplo de Latour, na relação entre texto e chave de leitura sendo a última um modo particular de transmissão que coloca o texto num certo regime de inteligibilidade. O direito, portanto, é umas destas práticas, como a ciência e a política, que possuem modos de existência distintos e irredutíveis, mas que juntas, cada uma à sua maneira, contribuem para a composição, "peça por peça", de um “Mundo Comum" (STENGERS, 2006).

Afastando a ideia de que o Direito teria uma essência transcendente e imutável, enraizada numa pressuposição abstrata (como defendia Kelsen), Latour argumenta que a própria essência do direito está numa prática que se estabelece na relação entre enunciação e instituição. Com isso muda o foco de análise, que sai do que o direito faz para como se faz. Faço aqui um parêntese explicitando o uso que faço dessa diferenciação apontada por Latour. O uso da letra minúscula para o direito, nesta tese, 
diz respeito mais as reflexões sobre o direito em ação do que a busca da posição ontológica do direito.

Quando uma vaga no Supremo é aberta, na maioria das vezes por aposentadoria compulsória aos 70 anos, vários nomes de juristas são "ventilados", expressão utilizada em referência aos nomes aptos a ser indicados pelo chefe do Poder Executivo. Mas o que faz um nome figurar na lista dos "ventilados"? Como é feita essa lista?

Para responder a essas perguntas, podemos começar com um dado apresentado num caderno de curiosidades editado pelo próprio STF, e escrito pelo ministro decano Celso de Mello: "Do total (287 Ministros), compreendidos ambos os períodos históricos (Império e República), todos os Ministros - exceto os Ministros Néri da Silveira, Cezar Peluso, Eros Grau, Cármen Lúcia e Menezes Direito - graduaram-se, no Brasil, por Faculdades públicas de Direito. No Império, as Escolas de Direito que forneceram os Juízes para o Supremo Tribunal de Justiça foram as de Coimbra, de São Paulo (Faculdade de Direito do Largo de São Francisco) e de Olinda/Recife”.

O que não quer dizer necessariamente que diplomas fazem ministros, ou pelo menos, não diretamente. A tese de Almeida (2010) já demonstrou o papel de algumas universidades na formação das chamadas elites jurídicas do país. Segundo o autor, existe uma hierarquia dos diplomas das faculdades de direito responsáveis pela formação dos estratos inferiores e superiores daqueles grupos profissionais. A essa hierarquia está relacionada à maioria dos cargos do chamado sistema de justiça. Em entrevista ${ }^{9}$, antes de ser indicado a ministro do STF, Roberto Barroso aponta para uma diferença fundamental no ensino jurídico no Brasil. Segundo o hoje ministro, existem faculdades de direito que têm por objetivo, mesmo que não explícito, levar um tipo de informação mais sofisticada a um público que a rigor não vai entrar no mercado de trabalho do direito, seja como advogados ou magistrados. Ainda assim, essas faculdades são importantes porque aprender direito ou conhecer o direito possibilitaria melhorar qualquer atividade profissional.

\footnotetext{
${ }^{9}$ Entrevista realizada em 21/05/2012 no antigo escritório de advocacia do ministro.
} 
Outros tipos de critérios operam nas indicações que não somente os diplomas de universidades prestigiadas. Determinados lugares no interior do sistema de justiça possibilitam que um nome seja cogitado para uma vaga na corte. Em entrevista a mim concedida durante a pesquisa, o ministro Luiz $\mathrm{Fux}^{10}$ ressalta algumas delas. Segundo o ministro, tradicionalmente, desembargadores do Tribunal de Justiça do Estado de São Paulo têm seus nomes figurando nas listas que chegam até a presidência. E, segundo consta do estudo de Almeida (idem), a maioria dos juízes atuantes nesse tribunal tem origem na faculdade de direito da USP, as chamadas arcadas. Curiosamente, conforme site especializado em questões jurídicas, "Consultor Jurídico", o TJSP é o maior tribunal do mundo, seja em número de julgadores (em 2008 eram 360), seja em número de processos. Além desses dados, o site identificou o perfil dos julgadores daquele tribunal.

\begin{tabular}{|l|}
\hline $95 \%$ são homens \\
\hline $90 \%$ são casados \\
\hline $17 \%$ se chamam Antônio \\
\hline $49 \%$ nasceram em São Paulo \\
\hline $41 \%$ estudaram na USP \\
\hline
\end{tabular}

Dos atuais ministros que compõem o STF, apenas Ricardo Lewandowski veio do TJSP, embora não seja o único formado pelas arcadas. Ainda segundo o ministro

\footnotetext{
${ }^{10}$ Entrevista realizada em junho de 2012. STF
} 
Fux, os estados da federação têm vagas em determinadas composições do tribunal. No caso da sua indicação, ele afirma que "tentou bastante". A primeira vez, conta o ministro, a vaga supostamente pertencia ao Rio de Janeiro, mas o indicado foi o ministro Menezes Direito, também ministro do STJ e "mais antigo".

Nesse caso, dois critérios operaram juntos: o primeiro, ser o ministro do Rio de Janeiro, e o segundo, ser proveniente de um tribunal superior, o STJ. Tribunais Superiores como o STJ ou o Tribunal Superior do Trabalho tradicionalmente têm alguns de seus membros indicados ao STF como candidatos naturais. Com a morte do ministro Menezes Direito, a vaga do Rio de Janeiro e do STJ ficou aberta, podendo o ministro Fux concorrer novamente. Mas, conforme o ministro, na segunda vez que tentou, "queriam uma mulher"; foi escolhida, então, a ministra Carmem Lúcia. Na próxima vaga aberta seu nome pôde finalmente ser considerado na disputa.

Para "concorrer", o futuro ministro precisa buscar apoio, formando listas com assinaturas de políticos, magistrados e advogados, que serão enviadas aos representantes do Poder Executivo. Costuma também se reunir com ministros de Estado, em especial com o ministro da Justiça, para se "colocar à disposição". É dessas reuniões que saem as outras listas que serão encaminhadas ao Presidente da República. O apoio de pessoas tidas como influentes dentro do Poder Executivo ajuda muito um candidato à vaga no STF. Esse apoio, somado ao lugar de onde vem o candidato, é condição fundamental para a nomeação. Dizem também, que os governadores dos estados, especialmente os aliados políticos do governo federal "fazem campanha" nas indicações tentando assegurar vagas aos representantes de suas regiões.

A Procuradoria-Geral da República, assim como a Advocacia-Geral da União, também formam nomes que sempre são lembrados nas listas que chegam à presidência. Na composição atual da corte e falo de 2013, três ministros vieram do Ministério Público, e dois deles ocuparam o cargo de Procurador-Geral da República. Assim como dois dos atuais ministros foram advogados da União. Procuradores e advogados públicos ou privados, quando indicados são transformados em juízes, passando para o "outro lado do balcão", como se costuma dizer, tendo de transformar rapidamente seu modo de operar o direito. Se antes ocupavam a tribuna do STF 
defendendo interesses específicos, terão agora outro papel no interior do sistema judiciário.

Os funcionários do tribunal que entrevistei diziam que o objetivo de indicar profissionais de diferentes carreiras jurídica, permite que o Tribunal seja composto por "diferentes sensibilidades jurídicas", em seus próprios termos. Alguns desses funcionários destacavam a importância de ministros com experiência no parlamento, como os ministros Paulo Brossard e Nelson Jobim. Diziam eles que a dinâmica do Tribunal era diferente. A lógica atual da pauta do tribunal, de que trataremos no capítulo seguinte, teria sido instituída pelo ministro Jobim. No entanto, conforme esses funcionários com quem conversei, as indicações vem se tornando cada vez mais "técnicas" sendo que a experiência política quase um demérito para os futuros ministros.

Mesmo que a finalidade da abertura de composição do Tribunal para diversas carreiras jurídicas seja a diversidade de experiências, quando um ministro toma posse o que se espera é uma transformação, que deixe suas experiências passadas. Durante a entrevista já citada, com o hoje ministro Barroso, em determinado momento ele me disse: "Eu tenho alma de advogado". Não o entrevistei depois da posse, mas acompanhei alguns dos primeiros julgamentos de que participou. Recordo-me de algumas vezes em que, quando o ministro mostrava preocupação com os advogados da tribuna, tentando encaminhar alguma questão para facilitar o trabalho de seus antigos colegas, como a publicação da pauta com antecedência, foi lembrado rapidamente por outro ministro de que não era mais advogado.

Certa vez o ministro Celso de Mello afirmou em um julgamento que advogados, promotores e juízes são ontologicamente diferentes. Uma nomeação para o STF promove uma passagem a um outro tipo de ontologia, o que me parece significar um outro tipo de perspectiva sobre os as causas e os processos. Quando falam da diferença em ser juiz do STF em relação a outras carreiras jurídicas, os ministros se referem principalmente à pressão e à cobrança social sobre seu trabalho, embora garantam que ela não tem influência no momento de decidir. Falam também das múltiplas competências exigidas de um ministro, que deve ter um voto para todo e qualquer tipo de processo. A ontologia a que aludia o ministro Celso de Mello parece 
estar relacionada aos meios e fins de cada processo. Um advogado saberia o lugar de chegada de seu raciocínio jurídico e quais interesses deve defender. Um juiz, ao contrário, não deveria ter um lado em uma disputa, pois estaria aberto a ser convencido pelo processo sobre qual tese jurídica pode ser tomada como verdadeira.

Um critério mais recente que passou a operar na indicação está relacionado ao enfretamento das desigualdades de gênero e ao racismo. A primeira mulher a ser indicada a ministra foi Ellen Gracie, nomeada em 2001. E o primeiro negro indicado foi o ministro Joaquim Barbosa.

Quando as listas chegam até a presidência, alguns nomes são selecionados para uma entrevista, realizada primeiro com o ministro da Justiça, e depois na presidência. A trajetória do ministro Roberto Barroso, descrita por ele durante a sabatina no Senado Federal, destaca esses momentos em que os candidatos são arguidos. Disse o ministro:

Eu não sei exatamente como eu cheguei aqui, senador. Eu verdadeiramente não tinha uma articulação política relevante. Eu fiquei muito honrado, muito feliz e muito surpreso. Geralmente, quando meu nome aparecia em alguma disputa, em alguma vaga para o Supremo, o sujeito que ia dizia que estava disputando comigo. Porque eu era o que não tinha nenhuma chance. Eu verdadeiramente fui pego de surpresa. Eu vou dizer pro senhor com absoluta honestidade as pessoas que em algum momento falaram comigo sobre esse assunto. $O$ ex-parlamentar e meu amigo de nome Sigmaringa Seixas me disse: seu nome é um dos nomes que a presidenta está considerando. O ex-secretário da casa civil, Dr. Beto Vasconcelos, foi uma pessoa que mais de uma vez me disse: seu nome é um nome que gostaríamos de ver no Supremo. Mais proximamente do desfecho, o ministro José Eduardo Cardoso conversou comigo, e depois a Presidenta da República me convocou. Eu estive no Palácio do Planalto levado pelo ministro da Justiça. 
Conversamos por aproximadamente uma hora, ela me fez uma sabatina inteiramente republicana. Não me perguntou sobre nenhuma questão especifica. Me perguntou sobre separação de poderes, questões sobre conflitos federativos. Conversamos sobre royalties. Ela me perguntou a posição que eu defendia para o Rio de Janeiro. Portanto, tivemos uma conversa republicana. Depois, na semana seguinte, ela me chamou pela segunda vez, conversamos uns 15 minutos sobre generalidades, e ela me fez o convite.

Embora secretas algumas dessas reuniões são noticiadas pela imprensa, que passa a afirmar que determinados nomes serão os escolhidos. Curiosamente, toda vez que um nome sai da imprensa como certo outro nome é de fato indicado.

Outro fator relacionado à indicação é a própria composição do Tribunal. As cadeiras vagas têm nome e algumas vezes têm perfil. Como se, em alguma medida, uma nova indicação tivesse de manter certo equilíbrio no Tribunal. Equilíbrio entre técnicas jurídicas diferentes, que permitem uma classificação dos juízes como conservadores ou progressistas, técnicos ou sensiveis. Para esse suposto equilíbrio, o currículo dos ministros ganha importância. Se foram juízes, o histórico de decisões tomadas pode ser analisado, assim como a atuação dos procuradores e advogados.

Quando então finalmente indicados - processo que pode levar meses - seus nomes são entregues ao Senado Federal, que irá realizar a chamada sabatina. Segundo alguns ministros, é apenas uma entrevista formal, já que os nomes sempre são aprovados. Assistindo a algumas delas, seu papel não parece ser o de recusar um candidato, embora tenha a liberdade para fazê-lo; o papel dos parlamentares e do candidato está em expor publicamente o notável saber jurídico. As sabatinas, dependendo do indicado, podem ser muito diferentes.

O momento da sabatina - realizada pela Comissão de Constituição e Justiça do Senado - também reúne autoridades do universo jurídico. É comum que quem apoiou o candidato esteja presente, além de representantes da Ordem dos Advogados do 
Brasil. A sessão começa por chamar os senadores que irão compor a mesa, concedendo a palavra ao senador responsável pela leitura de um relatório sobre o candidato. Dados da origem e da formação são então expostos. Logo em seguida, é o candidato que assume a palavra, para também falar de sua trajetória pessoal e intelectual.

Depois da primeira fala do sabatinado, os senadores podem se inscrever para fazer perguntas. Esse é o momento que usam para, além de arguir os candidatos, expor o que pensam sobre a atuação do Tribunal. No caso do ministro Joaquim Barbosa, que passou pela entrevista em maio de 2003, a sabatina apontava para um consenso entre os senadores presentes acerca da indicação. Foi considerada um "momento histórico". Um dos senadores presentes destacou a importância da nomeação, afirmando:

Por isso, com toda a sinceridade, creio que esse é o ato mais importante do Governo Lula, até agora. E, querendo ou não, esse será um ato que vai marcar o Governo Lula para todo o sempre, porque, no futuro, vamos dizer: "Te lembras daquela manhã, quando um tal de Lula manda um homem de cor que apareceu e foi indicado, e foi o primeiro, e agora está cheio, de tudo que é lado?" Esse é o momento que estamos vivendo.

E a felicidade de Lula está em estarmos aqui a felicitar o ato de escolher, para o Supremo Tribunal Federal, o primeiro homem negro. Mas o importante é saber qual é o nome.

Tive a gentileza de receber a visita do ilustre Ministro. E quero dizer que me encantei. Encantei-me pelo seu histórico, pela sua história, pela sua maneira de ser, pela sua simplicidade, pela vida que levou. Foi gráfico do Senado Federal, lutando, esforçando-se, avançando, conhecendo, preocupado em avançar, com o cérebro aberto ao infinito, ao conhecimento. 
Um homem que não guardou - não vi isso em nenhum momento da sua conversa - uma mágoa ou ressentimento por ter sido isso ou aquilo. Pelo contrário, conta os degraus que avançou e a caminhada que fez.

E terminou sua arguição tendo como certa a nomeação de Joaquim Barbosa:

Mas digo que V. Sa. vai marcar época no Supremo, não tenho dúvida nenhuma nesse sentido. Com seu estilo, sua maneira de ser, com a profundidade do seu pensamento, com a sua maneira de abordar as matérias, V. Sa. vai marcar época no Supremo Tribunal Federal.

Tendo em vista os desdobramentos da atuação do ministro Joaquim Barbosa, que será apresentada no quarto capítulo, os comentários do senador podem parecer um presságio. As outras intervenções e perguntas estavam quase sempre relacionadas à questão racial e à política de cotas, como área de especialidade do concorrente. Depois de arguido, o candidato respondeu às questões levantadas, agradecendo todos os comentários.

Mas nem sempre uma sabatina se conforma como uma celebração, ou um momento histórico. A indicação do ministro Dias Toffoli, que tinha sido advogado- geral da União, foi na época muito criticada pelo Senado pelo fato de ter sido ele advogado do Partido dos Trabalhadores, o mesmo do presidente que o indicou. Foi tida na época como uma indicação política. Como se em alguma medida essa indicação pudesse assegurar qualquer tipo de benefício ao partido em processos na corte. Durante a sabatina, seu notório saber jurídico e possíveis relações partidárias foram então 
questionados por mais de sete horas. Um dos senadores, durante sua arguição, perguntou ao candidato:

Indago se não há negligência na avaliação do notório saber jurídico, pois Vossa Excelência foi reprovado em dois concursos públicos. Não fez mestrado, nem doutorado, não há obra publicada. Sua trajetória profissional também não está ligada a grandes causas.

$\mathrm{Na}$ atual composição do tribunal, seis dos ministros possuem título de doutorado. $\mathrm{Ou}$ seja, os títulos acadêmicos podem representar um notório saber jurídico, mas não são os únicos levados em conta em uma indicação. Ao ser classificada como política, uma indicação é desqualificada, e mesmo se o candidato acumulasse títulos acadêmicos não deixaria de ser colocado em posição similar. Foi o caso da indicação do ministro Gilmar Mendes em 2002. O na época candidato trazia em seu currículo mestrado e doutorado defendidos na Alemanha, além de ser professor da Universidade de Brasília. Mesmo assim, ganhou a marca de uma indicação política.

$\mathrm{Na}$ defesa do futuro ministro Dias Toffoli, um dos senadores argumentou que o critério de notório saber é um fator subjetivo, dizendo:

Essa questão de saber jurídico é muito pessoal, mas por ter exercido a função de advogado-geral da União denota saber jurídico, além dos testemunhos de vários juizes e da OAB [Ordem dos Advogados do Brasil] atestando seu saber jurídico.

O notório saber então parece estar relacionado a um atestado. Que pode ser dado tanto pelos processos, quanto por autoridades, pessoas que já tenham seu notório saber confirmado. O próprio ex-presidente Luís Inácio Lula da Silva, em entrevista coletiva 
concedida em seu segundo mandato, afirmou a influência dos juristas Fabio Konder Comparato - professor emérito da faculdade de direito da USP - e Celso Antônio Bandeira de Mello - professor emérito da Pontifícia Universidade Católica de São Paulo - em suas indicações. O notório saber desses juristas se conforma como um lastro das futuras indicações em uma cadeia de autoridade.

Ademais, durante as sabatinas, os senadores buscam saber qual a posição dos futuros ministros nos processos já em andamento no Tribunal, e como avaliam a atuação da corte. Questão como essas colocam os candidatos em situação delicada. Por um lado, porque um juiz só pode se manifestar nos autos, sendo vedado o direito de emitir qualquer opinião sobre processos, sob pena de não poder mais julgá-los. Portanto, falar de processos no STF, tribunal em que se pleiteia uma vaga, seria contra as regras preestabelecidas para o julgamento. Além do que, fazer qualquer crítica ao tribunal seria descumprir um protocolo.

Quando então é aprovado pela Comissão de Constituição e Justiça, o nome do futuro ministro é submetido ao plenário do Senado e deve ser aprovado por ampla maioria. Só então o STF é avisado e pode marcar uma data para a solenidade de posse.

O costume é que o novo ministro receba de presente de seus apoiadores a toga, que irá usar nos futuros julgamentos. Algumas delas são herança de outros ministros ou juízes. Também escolhem o nome pelo qual preferem ser chamados no tribunal. Já empossados, independentemente de sua experiência ou de seu notório saber jurídico, serão ainda novatos, devendo respeito tanto ao tribunal e à sua história, quanto aos ministros mais antigos e sua autoridade já consolidada. A antiguidade é talvez o critério que mais opere nas relações estabelecidas, tanto entre ministros como entre os funcionários do STF.

É importante destacar que a indicação do presidente da República não é totalmente livre, porém cercada de todos esses critérios referidos. Nenhum presidente indica um nome completamente desconhecido do universo jurídico. Os ministros são, em certa medida, efeitos desses critérios, do aval de seus pares, do lugar em que atuam, da faculdade em que estudaram. 
O processo de indicação em grande parte das vezes exige uma atuação política dos candidatos, assim como dos ministros que intervieram politicamente durante a Constituinte. Entretanto, quando empossados, os ministros parecem transcender o espírito da política, diferenciando-se. O Exame da Ordem - visto no início do capítulo, é plenamente comportado dentro do universo jurídico, exatamente porque é um dos primeiros filtros que separam pessoas, mas, como procurei demonstrar, não é o último.

No próximo momento, tratar-se-á daquilo que movimenta o Tribunal e que dá vida as suas estruturas, a saber, os processos judiciais. Os autos processuais não apenas movimentam objetos - documentos - como todos os papéis anexados aos processos dão vida, materialidade, aos debates jurídicos, às concepções doutrinárias, aos valores e princípios enunciados pela Constituição. São assim, peças essenciais na produção jurídica, "objetos de todos os cuidados" (Latour: 2010), como também uma entrada metodológica, em que as redes se tornam visíveis e rastreáveis. 


\section{CAPÍTULO 2 - O PROCESSO}

"Auriverde pendão de minha terra, Que a brisa do Brasil beija e balança, Estandarte que a luz do sol encerra, $\mathrm{E}$ as promessas divinas da esperança... $\mathrm{Tu}$, que da liberdade após a guerra, Foste hasteado dos heróis na lança, Antes te houvessem roto na batalha, Que servires a um povo de mortalha!...

"Fatalidade atroz que a mente esmaga! Extingue nesta hora o brigue imundo O trilho que Colombo abriu na vaga, Como um íris no pélago profundo!... ... Mas é infâmia de mais... Da etérea plaga Levantai-vos, heróis do Novo Mundo... Andrada! arranca este pendão dos ares! Colombo! fecha a porta de teus mares!"

Esse trecho do poema "Navio Negreiro", de Castro Alves, foi declamado quase em conjunto pelos ministros Carlos Ayres Brito e Celso de Melo, pouco antes que o presidente da corte - o próprio ministro Ayres Brito - proclamasse o resultado da Arguição de Descumprimento de Preceito Fundamental 186, apresentada pelo Partido Democratas à corte. O Tribunal julgou a ação, por unanimidade, improcedente. Foi então que o público aplaudiu o resultado, comemorando a manutenção da política de cotas étnico-raciais em universidades públicas. A ADPF 186 questionava os procedimentos utilizados pela Universidade de Brasília $(\mathrm{UnB})$ no processo seletivo que reservava $20 \%$ das vagas para estudantes afrodescendentes.

No entanto, foi atrás da parede de mármore, sem as togas, sem os aplausos, sem as câmeras, que a ação foi ganhando vida, reunindo documentos, carimbos e assinaturas que em conjunto, compõem um processo judicial e permitem que se chegue a um resultado. 
Poderíamos, aqui, falar sobre a importância de uma decisão que reafirma as políticas afirmativas como fundamentais no combate ao racismo Brasil. Ou ainda, sobre um julgamento que arrancou lágrimas da plateia a cada defesa emocionada dos advogados. Contudo, ao seguir apenas o julgamento, o momento de proclamação do resultado, perdemos de vista que o direito no STF, como nos tribunais de modo geral $^{11}$, é produzido lentamente durante a composição de um processo judicial. Que a decisão é um efeito de um encadeamento de coisas e, seguindo as advertências de Bruno Latour (2010), para alcançar o direito (com letra minúscula) seria preciso substituir os grandes debates sobre Justiça, Direito e Norma por uma investigação meticulosa sobre os arquivos (processos) para ver aonde eles nos levam. Diz o autor:

não conhecendo o direito, é necessário ao etnógrafo, para seguir o movimento próprio, descobrir uma matéria que seja visível, estudável e reconhecível, que é objeto de todos os cuidados, de todas as conversações, que permite ir sem solução de continuidade desde a queixa mais inarticulada até os mais sublimes pontos de doutrina; essa é a matéria-prima do direito: o processo. (LATOUR: 2010, p. $83)$.

Seriam os processos que dariam a produção jurídica "materialidade", exatamente porque os documentos que compõem as pastas coloridas que são os autos processuais colocam em rede a produção jurídica nos tribunais. Os processos ${ }^{12}$ estão na superfície do conhecimento legal e são ferramentas da lógica jurídica inscrita numa racionalidade procedimental.

\footnotetext{
${ }^{11}$ Ver, por exemplo, as pesquisas de Barrera (2009), Onto (2012) e Latour (2010).

${ }^{12}$ Ainda que exista uma diferença entre processo e autos processuais, na rotina de trabalho do Tribunal ela desaparece.
} 
Ao acompanhar o desenrolar de um processo, desde sua invenção até sua "baixa" quando será enviado ao arquivo do tribunal - torna-se possível percorrer a produção e a trajetória dessas redes acumuladas nos autos processuais, tentando rastrear os recursos técnicos burocráticos, até alcançar seus dispositivos. Usa-se aqui o termo de Latour, que é também uma categoria nativa. O autor argumenta que a ideia de dispositivo está relacionada a uma ponte ou várias pontes que devem ser construídas nos processos, conectando os diferentes tipos de documentos, ou as cadeias de declarações e argumentos que compõem os autos processuais. Só desse modo se pode produzir um dispositivo, a saber, a decisão.

Neste capítulo buscaremos seguir a produção e a trajetória de um processo, porquanto são os caminhos e o encadeado de coisas consideradas conjuntamente que constituem a prática de conhecimento do direito no âmbito do tribunal. Nesse sentido, como afirmou Barrera (2009) em sua pesquisa na Suprema Corte Argentina, em instituições jurídicas importa menos o poder dos atores de "dizer o direito" (Bourdieu, 1987) do que o desenvolvimento de trajetórias legais qualificadas, exatamente porque, para que os discursos tenham validade, devem ser inscritos na lógica procedimental do tribunal.

Lembro-me aqui das próprias estratégias que tornaram o trabalho de campo possível. Todas as vezes que tentei entrar em contato com os gabinetes ou com as seções do STF, era logo avisada de que havia uma necessidade de "formalização" do pedido, para que este fosse autorizado. Que eu deveria enviar ao presidente do Tribunal uma cópia do projeto de pesquisa em papel timbrado da universidade, a ser entregue ao chefe de gabinete, acompanhado de um comprovante de matrícula. Com esses documentos em mãos, o chefe de gabinete daria ao meu pedido um encaminhamento formal, "despacharia" com o ministro, e assim que houvesse uma resposta à solicitação, eu seria avisada através de outro documento que deveria ser entregue à seção, evidenciando que havia uma autorização formal para a minha presença. Mais tarde fui avisada que o Tribunal iria deliberar os procedimentos para pesquisas como a minha e então eu seria informada. 
Prezada Dra. Andressa:

Sua solicitação foi encaminhada à Dra. Carolina Yumi, Chefe de Gabinete da PresidênciaSTF.

Prezada Dra. Andressa,

Preciso que encaminhe alguns documentos para que possamos encaminhar: o projeto de tese de doutorado; documento da universidade comprovando sua matrícula; contatos atualizados para que sejam inseridos no sistema. Também, se possível, gostaria que detalhasse melhor a que áreas do Tribunal você precisa ter acesso e se isso incluiria os gabinetes dos Ministros, para que possamos verificar adequadamente qual o melhor encaminhamento à solicitação.

Chefe de Gabinete da Presidência

Supremo Tribunal Federal - STF

((61) 3217-4209

Prezada Dra. Andressa,

Está-se estabelecendo um procedimento para tratar situações de pesquisadores, pois tivemos alguns pedidos recentemente de acesso ao STF. Deve haver alguma deliberação nos próximos dias. Assim que tiver notícias, encaminho documento com a decisão. 
Ainda que minha pesquisa não tratasse de uma questão jurídica, o meu pedido deveria se inscrever nos procedimentos e viraria um tipo de recomendação para as pesquisas que virão. Sem os documentos não era possível ao chefe de gabinete autorizar a pesquisa, despachar com o ministro, assim como, sem a autorização formal do gabinete, nenhum funcionário da Secretaria Judiciária poderia permitir minha entrada.

Como "emblemas" da burocracia moderna, Riles (2010) argumenta que os documentos articulam, mediam relações e permitem visualizar aquilo que é produzido através deles ou a partir deles. Especialmente, como destaca Barrera (2011), em culturas de tradição civilista, como o caso brasileiro, em que as práticas judiciais se articulam, sobretudo, através de documentos escritos. Como se "só existisse no mundo o que está corroborado no papel" (PEIRANO: 2009, p. 70). De fato, no caso da operação jurídica não existe o "como se" apontado por Peirano; pelo menos, em tese, só existe no mundo aquilo que está no processo, e quando assim não é, temos um problema, segundo os ministros, que repetem a frase dezenas de vezes ao longo dos julgamentos. Um dos funcionários do Tribunal, com o qual conversava com certa frequência, particularmente quando me parecia impossível compreender o que se passava no movimento processual, disse-me que se restringir ao processo era uma garantia e um modo de limitar a discricionariedade do juiz. Exatamente porque o processo é instrumento de liberdade, de conquista de direitos, e, sobretudo de controle. Disse-me ele:

Pense comigo. Limitar a atuação ao processo pode parecer estranho, mas é um instrumento importante. Quando se fala em livre convencimento do juiz, se imagina que uma pessoa tem esse poder extraordinário para decidir, mas não é bem assim. Exatamente porque um juiz é uma pessoa comum, que vê televisão, lê jornais, vota nas eleições. E não estou dizendo que um juiz é neutro, pois, como se sabe, ninguém é; mas existem formas de controle que estão 
no processo, nesse amontoado de documentos que tanto impressionam $^{13}$.

Em outras palavras, o que ele me dizia era que, quando entra em cena em um julgamento, coisas que não constam dos autos processuais elas não podem ser debatidas por quem está em qualquer um dos lados do processo; tampouco podem ser contraditadas. Conforme Visman (2008), a dupla negação, não está no mundo e não está no processo sumariza a operação performativa do direito na constituição da realidade e deixa claro que o direito e a realidade fora dele não são coincidentes (p.560)

Em alguma medida, todo expediente legal destina-se a garantir a composição dos autos processuais. Neste capítulo pretendo reconstituir a circulação de um processo e compreender a economia processual que envolve pessoas, documentos e procedimentos no STF. Pelos processos é possível entender a forma de administração do Tribunal, as relações que se estabelecem, além de alguns indicativos do caminho da decisão, tendo em vista que um ministro na sua decisão não interpreta as ações no mundo, mas os atos documentados nos processos. Os processos, seguindo Barrera (2009), falam de eventos, de procedimentos de registros, são constituintes de uma série de relações de conhecimento dentro do aparato judicial.

O primeiro contato com um processo, pelo menos para alguém não acostumado, é certamente um pouco assustador. Várias pastas coloridas, e dentro delas papéis e mais papéis, numa sequência quase interminável de coisas colocadas juntas, num tipo de ordenamento específico que deve levar em conta a data de entrada dos documentos no Tribunal, os prazos legais de cada processo, os tipos de argumento e os documentos probatórios. A fim de entender esse ordenamento e os procedimentos que constituem os processos, vamos tomar como referência os autos processuais da ADPF 186.

\footnotetext{
${ }^{13}$ Entrevista realizada em marco de 2012
} 
Tudo começa no STF, a partir de um conjunto de documentos que compõe a denominada petição inicial. O próprio nome dessa peça processual já é curioso: é como se demandar um direito significasse a mesma coisa que pedir um direito. De todo modo, o objetivo de uma petição inicial é provocar a jurisdição que é exercida pelo Tribunal, ainda que essa jurisdição tenha ao longo do tempo de transformado, não sendo consensual quais os limites em que podem atuar os ministros e o tribunal. $\mathrm{E}$ digo isso pensando na ideia de nova corte, que falava no capítulo anterior.

As peças iniciais podem ser entregues de duas formas. Em processos eletrônicos, todo procedimento deve ser realizado pela internet, dentro de um programa específico do STF, que pode ser acessado por advogados a partir de um certificado digital; este funciona como uma identidade virtual, guardando dados pessoais e profissionais. Quando o processo é físico, duas vias da petição devem ser entregues à Central do Cidadão e Atendimento, setor que reúne a Seção de Protocolo e Atendimento Presencial, a Seção de Atendimento Não Presencial e a Central do Cidadão ${ }^{14}$. Nessa seção a petição que deu origem à ADPF 186 foi entregue no dia 20/7/09.

A seção é um espaço grande - 1.700 metros quadrados -, localizada no térreo do prédio anexo 2, com uma entrada específica, que não é a mesma que leva aos gabinetes. Uma bancada de madeira separa o ambiente interno - de acesso exclusivo dos funcionários - do externo, por onde chegam os advogados. Compõe ainda o atendimento uma sala menor, para uso dos profissionais do direito. É uma parceria do Tribunal com a Ordem os Advogados do Brasil (OAB), que disponibiliza recursos técnicos (computadores e impressoras) para que os advogados possam adequar os documentos às normas do STF, sobretudo a partir de 2010, quando o envio de petição eletrônica se tornou obrigatória em algumas classes de processos, como ADI e ADC, por exemplo. Ainda que seja um espaço exclusivo para receber o público, com poltronas de couro confortáveis, não é comum uma grande circulação de pessoas na seção. O público que frequenta as dependências do STF é formado basicamente por

${ }^{14}$ A Central do Cidadão recebe diariamente uma centena de cartas e e-mails de cidadãos não advogados com diversos pedidos aos ministros. Grande parte das cartas recebidas é enviada de presídios. 
profissionais do direito, embora esta não seja uma condição para o acesso. Qualquer pessoa pode solicitar informações ao Tribunal dirigindo-se ao atendimento, ainda que em algum momento vá se deparar com a pergunta: “Quem é você?”. A pergunta tenta esclarecer quem é você em relação a um processo: se é parte, se é advogado, se é interessado.

Quando chegam, os advogados, quase sempre portam uma pasta preta e aguardam ser chamados em um dos quatro guichês do protocolo, entregando ao funcionário uma série de papéis assinados e carimbados. São carimbos dos escritórios de advocacia, dos cartórios que autenticam assinatura, e cópias de outros documentos. Os carimbos desses papéis é o que garante aos ministros a correspondência entre a cópia e o original. Já encontrei processos com cópias não autenticadas, aos quais se negou seguimento até que o "problema fosse resolvido".

A petição inicial da ADPF 186 é composta de 610 páginas, com diversos tipos de documentos incluídos. Entre eles estão: a petição em si, ou seja, o documento que expõe os motivos de um possível descumprimento de princípios constitucionais, uma procuração outorgando poderes ao advogado da causa, e 11 anexos: as resoluções que regulamentam a política de cotas raciais na Universidade de Brasília, pareceres elaborados por professores doutores de universidades brasileiras e uma série de decisões proferidas por outros tribunais, referentes à reserva de vagas em universidades públicas.

Quando entregue, a petição é registrada no sistema eletrônico do Tribunal (E-JUD). O registro é realizado a partir da transposição dos dados, que costumam estar na primeira folha de uma petição - nome da parte autora, classe processual a que se destina e advogado representante. Ao ser registrada a petição, o sistema gera um número de protocolo que é entregue ao advogado, confirmando o recebimento. É por esse número que os advogados podem acompanhar, pelo menos em parte, a movimentação dos documentos entregues, pois cada um dos deslocamentos registrados no sistema indica uma fase de tramitação (Ver Anexo 2)

A partir desse momento, inicia-se toda a trajetória desse conjunto de documentos dentro do Tribunal. As petições saem do atendimento com destino ao Processamento 
Inicial, lugar em que acontece uma triagem do material entregue. Recursos e ações originárias se dividem dentro desse setor em salas específicas e especializadas. São verificados aqui alguns dos requisitos formais de admissão de cada tipo de petição: presença de todas as peças processuais e o prazo regular de cada classe. Nas ações de controle concentrado, das ADI, ADPF, ADC, essa triagem é uma conferência de tudo o que foi entregue, ao contrário dos recursos, em que esse procedimento é muito mais complexo, pelo menos depois do instituto da Repercussão Geral, já mencionado no capítulo anterior.

No caso dos Recursos Extraordinários, operam os filtros da Repercussão Geral, que funcionam com base em temas numerados: cada tema corresponde a uma questão jurídica. Por exemplo: tema 241 - identifica controvérsia relacionada à obrigatoriedade do Exame da Ordem, tema 347 identifica a controvérsia relacionada ao Direito à atualização monetária do vale-refeição dos servidores públicos do Estado do Rio Grande do Sul por decisão judicial - nesse tema incidem os assuntos 10304 ( Auxílio-Alimentação) e 10313 (Servidor Público Civil). Aos funcionários da seção cabe identificar nos recursos recebidos se eles correspondem a algum tema já decidido ou com Repercussão Geral já reconhecida, ou se inauguram um novo tema e devem ser remetidos aos ministros. Quem inventa os temas a rigor, são os assessores da presidência, no entanto como quem recebe os recursos é a SEJ dali saem várias sugestões de possíveis novos temas a serem cadastrados.

Essa primeira análise, realizada pelos técnicos e analistas, visa separar coisas iguais e coisas diferentes, entendendo-se por coisas iguais as já decididas e que terão a mesma decisão. Esse parece ser o princípio da segurança jurídica. Ali mesmo, na seção de recursos, os processos são decididos, aplicando-se o precedente. Cada recurso "repetido" corresponde uma decisão, tornada modelo, que é então assinada pelo presidente do Tribunal. Existem várias modelos de decisão produzidos pela presidência, e a aplicação do modelo é supervisionada pelo chefe da seção e pelos assessores da presidência. Algumas vezes os analistas identificam erros na "aplicação" dos modelos o que evidencia que a "técnica" que identifica conexões e semelhanças entre os recursos exige dos servidores uma compreensão da demanda que não é consensual. 
Os modelos de decisão também se aplicam a recursos fora do prazo e na falta de documentação. Quando estive na seção, observei um funcionário ensinando uma funcionária nova a encontrar as peças no processo. Com os autos em sua mesa, dizia ele: "Está vendo aqui? (apontava para o timbre do papel que identificava o tribunal que proferiu decisão anterior). Esse é o acórdão recorrido; você marca essa peça e anota o número da página, aqui” (e apontava para um formulário em cima da mesa). Saber como procurar as peças identificando pelos timbres dos papéis quais os tipos de conteúdo de cada um dos documentos possibilita aos funcionários uma leitura estratégica dos autos, com vistas a preencher um formulário com o que consta e o que falta. O preenchimento de cada tópico do formulário indica procedimentos que devem ser acionados.

No caso dos processos originários do controle concentrado, o papel da secretaria é mais restrito. Essa categoria de processos costuma ter uma trajetória mais longa, que requer outros procedimentos depois de sua autuação. Conforme a definição jurídica, o termo autuar significa colocar em processo. É esse o procedimento que acontece com uma petição que ao ser autuada se transforma em processo.

Ao ser autuada, todas as páginas da petição são carimbadas com o selo do STF e numeradas - à caneta, seguindo uma nova ordem que leva em conta os papéis de registro produzidos pelo Tribunal e incluídos nos autos. Essa nova numeração deverá servir de referência em todo o processamento. O que pode parecer uma bobagem - a numeração das páginas - é um ato processual que determina o que está ou não nos autos, faz parte ou não do processo. Existem determinações dos próprios ministros para acrescentar ou excluir documentos. Quando isso acontece, tudo é renumerado.

Ao ser autuada, a petição da ADPF 186 foi colocada em uma pasta cor de rosa, que identifica sua classe processual, com um número etiquetado: 186 (numeração contínua para cada classe). Também foi etiquetada na capa e na primeira folha da petição, um código de barras e outra etiqueta na qual constam as instituições e pessoas do processo, transformadas agora em partes e classificadas como arguidos e arguentes: 


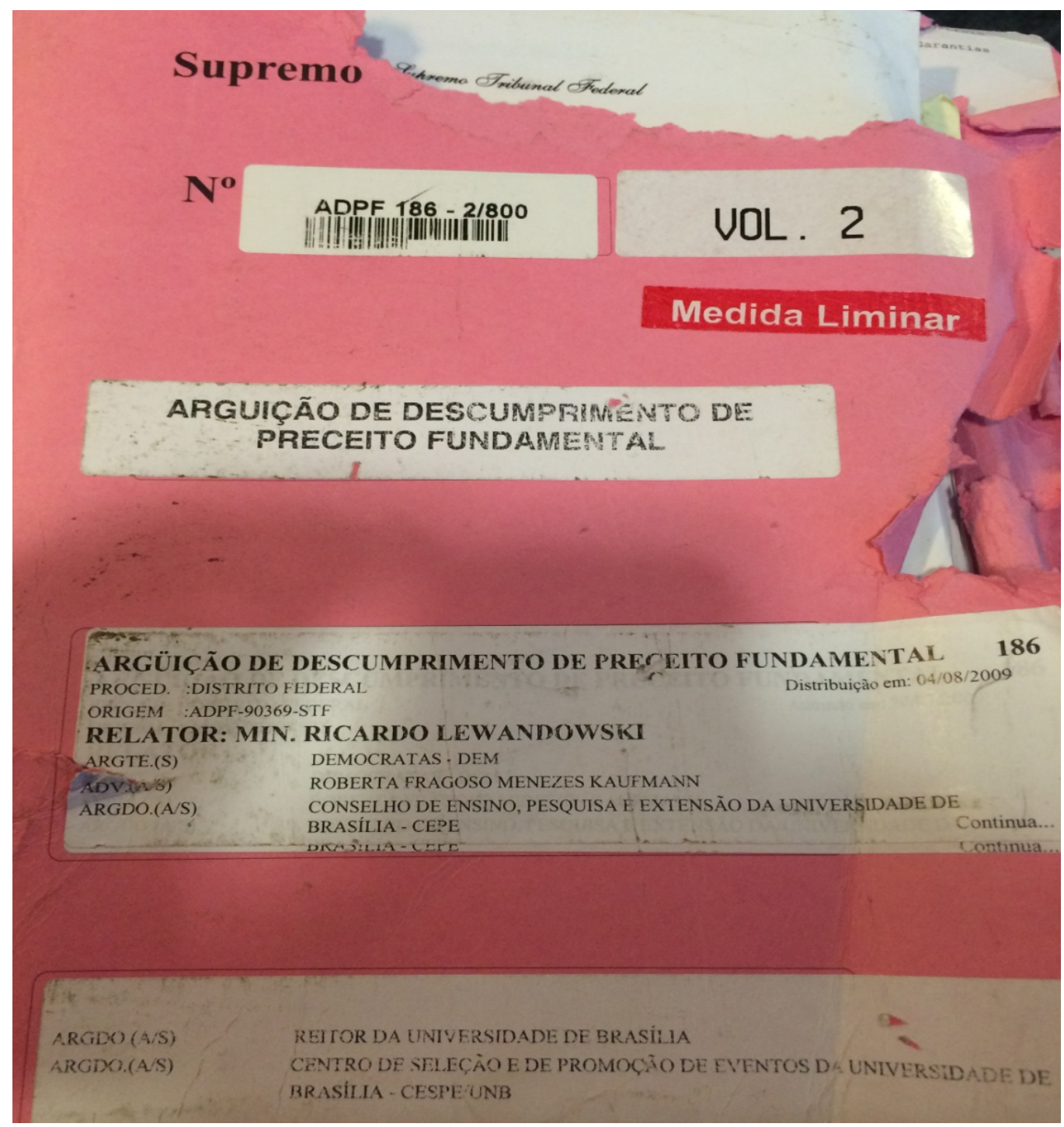

Figura 3 - Volume 2 dos autos da ADPF 186.

Essa primeira etiqueta não é definitiva, sendo substituída diversas vezes no decorrer do processamento, de acordo com a inserção de outras pessoas e instituições nos autos. O procedimento de identificar nos autos quem são as pessoas/instituições, inserindo-as em categorias distintas (arguente, arguido, interessado), implica dar a cada uma delas uma posição no processo. 
Ainda na plataforma virtual, o servidor estabelece uma primeira indexação, que segue a Tabela Única de Assuntos Processuais ${ }^{15}$, editada pelo Conselho Nacional de Justiça com o objetivo de padronizar o cadastro de processos e facilitar o controle estatístico do Poder Judiciário. Para a indexação, é necessária ao funcionário uma mínima compreensão do que se passa naquele processo, da natureza do pedido, caso contrário a indexação pode induzir a erro.

Perguntei a um analista judiciário a respeito da indexação, e ele me respondeu que caso ela esteja errada e os funcionários do gabinete não leiam os autos ou pelo menos parte deles, o processo será classificado de forma errada, o que "prejudica os trabalhos". Quando erros são identificados, o processo é internamente reclassificado. E aqui existe uma observação a ser feita. Se os termos da indexação forem inadequados ao processo, mesmo que o erro seja identificado pelo gabinete, ele não será corrigido pela Secretaria Judiciária. Conforme me esclareceu o funcionário, não cabe ao gabinete interferir nos trabalhos realizados fora dele.

Desta forma foi indexada a ADPF 186:

\section{DIREITO ADMINISTRATIVO E OUTRAS MATÉRIAS DE DIREITO PÚBLICO | Controle de Constitucionalidade \\ DIREITO ADMINISTRATIVO E OUTRAS MATÉRIAS DE DIREITO PÚBLICO | Garantias Constitucionais}

No sistema informatizado da SEJ, cada área do direito, das 16 identificadas, funciona como pastas: ao clicar em uma área, aparecem outras opções, e dentro delas, ainda outras, tornando a indexação cada vez mais específica. Uma das vezes em que me encontrava na seção, vi em cima de uma das mesas um manual para identificação de

\footnotetext{
${ }^{15}$ A tabela utilizada pelo STF possui algumas modificações realizadas pelo Tribunal de modo a adequá-la às suas competências exclusivas.
} 
assuntos e as classes das petições. Folhando algumas das primeiras páginas observei algumas recomendações para essas identificações. A primeira delas sugeria perguntas a serem respondidas pelo servidor. Fazendo recomendações sobre como responder a essas perguntas, o manual identificava em que lugar da petição estariam as respostas.

Do que se trata esse processo? Qual a relação jurídica entre as partes? A resposta, geralmente, encontra-se no início da petição. O que se quer com esse processo? Em petições bem formuladas, em regra, a resposta está ao final da petição.

Reconhecendo os assuntos e as demandas é possível então registra-las com mais precisão. O modo como foi indexada a ADPF 186 é um primeiro elemento que permite dizer que a ação não será comum, mas uma daquelas classificadas como hard cases. Essa distinção jurídica entre casos mais ou menos complexos parece estar relacionada às dúvidas que emergem da questão apresentada, acerca da própria legitimidade do Tribunal para decidir controvérsias que ultrapassariam suas competências, fato este relacionado à dificuldade de submeter o processo a uma regra clara preestabelecida, que nesses hard cases é inexistente (Dworkin 2002). Faço aqui um parêntese que me parece importante. Nos termos dos ministros, além de existirem casos difíceis e fáceis, existe outra diferença entre casos "juridicamente difíceis" e “socialmente delicados". Essa distinção opera nos modos como a decisão será tomada.

Ao indexar os autos de modo genérico (garantias constitucionais), o servidor indica que o sistema de classificação não possui categorias relacionadas diretamente com o processo apresentado. Segue-se desta primeira classificação uma aposta: a de que a ação vai inaugurar alguma coisa, alguma possibilidade futura de etiquetagem mais específica. Para ilustrar a comparação, apresento outras indexações relativas à mesma classe de processo. 
ADPF 123

DIREITO DO TRABALHO | Direito de Greve / Lockout | Interdito Proibitório

ADPF 165

DIREITO ELEITORAL E PROCESSO ELEITORAL | Eleição | Pleito |

Quociente eleitoral

\section{ADPF 164 \\ DIREITO ELEITORAL E PROCESSO ELEITORAL | Mandato | Extinção do mandato | Por suspensão dos direitos políticos}

A indexação seria um primeiro frame do processo - uso aqui a definição de Bateson (1972). De acordo com o autor, a definiç̧ão de quadros (frames) determina todo um sistema de premissas para a leitura da mensagem. Cardoso de Oliveira (2008) já destacou a prática jurídica de "redução a termo" como mecanismo de filtragem interpretativa. Segundo o autor:

O foco do Juizado na "redução a termo" das disputas, filtrando apenas a dimensão estritamente legal dos conflitos, talvez permita pensarmos numa certa fetichização do contrato - como categoria englobadora das prescrições jurídicas de todo tipo -, característica do direito positivo, em que o espaço para articular demandas é limitado ao que está estipulado no contrato e no código penal (ou 
civil), como prescrições autocontidas, autossuficientes e abrangentes o bastante para equacionar os conflitos que chegam ao Judiciário. (p. $138)^{16}$.

No STF, no entanto, não é um cidadão leigo que relata uma ocorrência a ser transformada em categoria jurídica; ao contrário, os advogados das ações de controle concentrado, já na petição inicial, indicam quais filtros devem ser acionados.

Somado a isso, o número de processos recebidos diariamente pelo STF impossibilita uma leitura muito rigorosa de tudo o que é entregue. Desse modo, a indexação costuma seguir os termos da petição inicial, corrigindo apenas "erros grosseiros", conforme me relatou uma das funcionárias. No programa de envio de petições eletrônicas existem campos a ser preenchidos pelos advogados, de acordo com as opções apresentadas no próprio sistema, que já formam uma primeira indexação. De certa forma, os advogados participam do processamento, assim como o Tribunal participa da própria petição. Por exemplo, uma petição pode chegar ao STF destinada a uma classe específica e ser internamente convertida em outra.

Com todos os procedimentos pertinentes ao processamento inicial realizados, o processo é transferido para a Seção de Prevenção e Distribuição. Cada movimento dos autos deve ser registrado em uma guia de deslocamento recebida pelas seções para onde eles se destinam. Quem os recebe confere, e nesse caso a numeração das páginas é fundamental, registra, e recebe.

A partir das entrevistas pode-se dizer que o maior pesadelo de um funcionário do Tribunal, seja dos gabinetes, seja da secretaria, é perder um processo. Para tentar minimizar tal risco existem várias ferramentas, das mais rudimentares às mais refinadas, que auxiliam os servidores a encontrar um processo em meio a centenas de

${ }^{16}$ CARDOSO DE OLIVEIRA, Luís Roberto. Existe violência sem agressão moral? Rev. Bras. Ci. Soc. [online]. 2008, vol. 23, n. 67, pp. 135-146. ISSN 0102-6909. 
pastas da mesma cor colocadas nas estantes e espalhadas pelo chão das salas. Cada movimento dos autos, que pode ser da mesa para a estante, é anotado, registrado e assinado. Quando os autos saem das seções, os funcionários identificam para onde ele deve ser deslocado, separam os volumes, preparam a guia, registram no programa, enviam os processos e aguardam o comprovante da entrega, para novamente registrar no sistema onde ele está.

Na Seção de Prevenção e Distribuição a petição inicial da nossa ADPF foi dividida em dois volumes, anexando-se ao processo um termo de encerramento e um termo de abertura para o segundo volume. Qualquer transformação dos autos deve ser identificada por esses termos, que levam a assinatura dos servidores responsáveis.

Dividir em volumes o processo faz parte da preparação dos autos para que seja distribuído a um relator, procedimento que ocorre diariamente na seção, embora nem todos os processos que cheguem sejam distribuídos no mesmo dia. Há casos de acúmulo de processos na seção. No entanto, não foi o que aconteceu com a ADPF no dia 20. A inicial foi entregue no mês de julho, época de recesso forense, quando os ministros não estão na corte, sendo os autos transferidos para outra seção: a Seção de Controle Concentrado e Reclamações. Normalmente o processo ficaria parado até o retorno nos ministros, todavia, ao registrar um pedido cautelar incluído na petição, o setor deve encaminhar os autos ao ministro de plantão.

O processamento dos autos obedece a diversas regras de atração, que obrigatoriamente incidem sobre sua trajetória. Os servidores devem conhecer os tipos de processos e as peças processuais que exigem determinados encaminhamentos. No caso da ADPF 186, ela foi enviada - carregada em carrinhos que percorrem as seções e os gabinetes - à presidência, responsável pelos processos tanto em períodos de férias como na época do recesso. O movimento dos carrinhos acontece algumas vezes ao dia, com o acúmulo de documentos a serem deslocados de um lugar para o outro. Os autos são transportados amarrados com uma fita branca, para que se assegure que não serão violados no trajeto.

Até o momento da distribuição, os processos são de responsabilidade da presidência, o que não significa que todos são enviados a ela. Medidas cautelares pedem, no 
entanto, que uma decisão seja concedida rapidamente, o que atrai a competência da presidência e seu deslocamento físico até ela. Uma medida cautelar é um pedido liminar que antecede ao julgamento do mérito. O Partido Democratas visava suspender a matrícula dos estudantes aprovados no vestibular da Universidade de Brasília em 2009, que ocorreria nos dias 23 e 24 de julho (três dias depois da entrega da petição). Pretendia também que o Tribunal suspendesse os processos seletivos de outras universidades que adotaram a reserva de vagas até o julgamento definitivo da ação.

Chegando à presidência, o processo é recebido por um funcionário do gabinete, que também deve assinar a guia de deslocamento, permitindo o registro no sistema, o eSTF-gabinete, ou E-GAB, como é mais conhecido. Esses registros de localização são disponibilizados também aos interessados no processo, através da internet, mas dependem da liberação de visualização, que é feita pela Secretaria Judiciária, com a autorização dos ministros. Os processos chegam aos gabinetes misturados, ou seja, várias cores de pastas chegam juntas no mesmo carrinho. $\mathrm{O}$ funcionário do "protocolo" separa as cores, distribuindo os processos aos funcionários especializados em cada um delas.

Ainda nos gabinetes existe um sistema de controle da movimentação, tanto em pequenas fichas que são temporariamente anexadas aos autos, como por meio do sistema informatizado. Esses procedimentos de localização permitem rastrear quais funcionários estão com determinado processo e em que estágio do processamento ele se encontra.

Ao adentrar o gabinete, o processo deve seguir a linha de produção das decisões, passando por diversos funcionários - ou conjuntos de funcionários - de estamentos diferentes, para que sejam realizados todos os atos administrativos necessários. Cada gabinete cria uma série de fluxogramas de processamento que devem ser cumpridos pelos servidores antes que os autos cheguem ao ministro.

O primeiro procedimento realizado é a marcação das peças processuais. Com post-its amarelos ou pequenos papéis cortados, o servidor identifica cada parte dos autos e separa o pedido de medida cautelar, para que seja avaliada a urgência da decisão. A 
primeira questão que deve ser identificada pelo funcionário na análise da ADPF é quanto ao responsável pela ação. Grande parte das ADPFs recebidas pelo tribunal estanca já nesse primeiro momento, por falta de capacidade postulatória do arguente e legitimidade para usar o instrumento. A Constituição determina quem pode propor uma ADI e os mesmos proponentes funcionam para as ADPFs. São eles: o Presidente da República; o Procurador- Geral da República; os Governadores dos Estados e o Governador do Distrito Federal; as Mesas (órgãos administrativos) da Câmara dos Deputados, do Senado Federal, da Câmara Legislativa do Distrito Federal; Partidos Políticos com representação no Congresso Nacional; Conselho Federal da Ordem dos Advogados do Brasil (OAB); Entidades de Classe de Âmbito Nacional e Confederações Sindicais.

A capacidade para propor uma ADPF ou uma ADI, ou qualquer outra ação do controle concentrado, está também vinculada à ideia de legitimidade universal e especial. O que engendra essa diferenciação é a noção de interesse, ou, dizendo de outra forma, dos tipos de interesse que podem mobilizar pessoas, sejam elas físicas ou jurídicas, a questionar a constitucionalidade de uma lei ou ato normativo. Entre os legitimados universais estão às autoridades públicas federais, o Presidente da República, o Procurador- Geral da República, além dos representantes de pessoas jurídicas de direito público, como a mesa da Câmara e do Senado Federal. Entre as pessoas jurídicas de direito privado, apenas os partidos políticos e o Conselho da Ordem dos Advogados do Brasil ganharam legitimidade universal. Todos os demais são considerados legitimados especiais e devem apresentar pertinência temática para propor uma ação. Pessoas físicas ou naturais devem recorrer ao Ministério Público para representá-las diante da Suprema Corte.

No nosso caso, bastou ao servidor identificar que se tratava de um partido político, um dos legitimados universais para a propositura da ação, para que ela seguisse em frente. O passo seguinte é extrair dos documentos entregues o objeto jurídico em debate e os fundamentos legais do pedido. Esse objeto ou questão jurídica deve ser mapeado a partir da legislação a que se refere, dos precedentes que aparecem, e de alguns elementos da narração dos acontecimentos. A semelhança entre o que será decidido pelo Tribunal e o que a demanda apresenta depende da capacidade do advogado em formular a questão com "clareza" e "objetividade". Durante o trabalho 
de campo acompanhei algumas dessas primeiras análises das petições iniciais, e inúmeras vezes ouvia os técnicos judiciários ressaltarem a dificuldade em compreender as demandas formuladas.

De modo geral, os analistas judiciários reclamavam da falta de documentos fundamentais ou do excesso, da forma confusa como eram apresentadas as demandas e da falta de precisão na utilização dos precedentes. Quando uma formulação é avaliada como absolutamente incompreensível ou quando a ela faltam documentos importantes, o gabinete nega seguimento ao processo. Ao acompanhar algumas sessões de julgamento é possível notar a dificuldade dos ministros em chegar a um consenso sobre a pretensão dos processos.

Todavia, questões importantes quase sempre são apresentadas por advogados especializados, sendo uma parte deles bastante conhecida do Tribunal por sua atuação de longa data em processos que correm no STF, ou ainda por sua reputação no universo jurídico. Desse modo, é mais difícil que cometam "erros" nas formulações das petições.

Menciono um comentário que ouvi de um assistente do plenário durante um julgamento. Enquanto um advogado se preparava para subir à tribuna e realizar sua defesa, o funcionário comentava com o colega ao lado: "Ihh! Essa causa já está perdida. Ele mal sabe colocar a toga" - referindo-se à dificuldade do advogado para vestir a beca obrigatória. Mais tarde, durante o intervalo, perguntei ao assistente sobre o comentário, e ele me respondeu: "Nós estamos acostumados a ver muitos advogados aqui, e sabemos quando eles estão preparados para um processo na Corte. Não é fácil para ninguém subir naquele púlpito e falar diante dos ministros. Nem mesmo produzir teses jurídicas que podem convencer os ministros. Mas existem aqueles advogados acostumados, que sabem como proceder. Tem tanto conhecimento como qualquer um dos ministros do Tribunal. Advogados bem preparados têm a barra da calça benfeita", disse, rindo, deixando claro que se tratava de uma brincadeira. A reputação dos advogados e sua expertise reconhecida conferem ao processo a garantia de qualidade. 
$\mathrm{Na}$ análise das petições entregues ao Tribunal, operam o que Riles chamou de “critérios estéticos". Uma estética que não significa beleza, mas como indício do poder da forma para definir limites e possibilidades (2011a, p. 54). Conforme a autora, os critérios estéticos são reivindicados pelos operadores do direito como sendo sua expertise técnica, e essa expertise será testada pelo Tribunal.

Não existem formulários para uma petição, mas existem regras que devem ser cumpridas pelos advogados, e documentos obrigatórios. Em uma ADPF, a petição deve indicar quais preceitos fundamentais considera violados, quais os atos ou qual o ato questionado, apresentar as provas de violação, além, é claro, de apresentar os argumentos dentro da gramática própria do direito. Quando analisou os documentos que apresentavam as "missões" das universidades do Reino Unido, Strathern (2006) argumentou que esses documentos incorporam práticas textuais que podem parecer familiares aos acadêmicos, mas que, no entanto, pertentem a um mundo próprio. Os documentos produzidos em uma petição seguem uma lógica similar, embora poucas vezes familiares, cumprindo padrões estéticos de inteligibilidade próprios ao universo jurídico.

Se uma parte dos "critérios estéticos" foi atendida (nem todos os requisitos formais são decididos apenas pelo ministro relator, existem aspectos que só serão decididos durante o julgamento), outros procedimentos podem ser acionados para que o processo comece a ser composto. O primeiro ato processual é sempre o mesmo: o gabinete requisita informações e manifestações a pessoas e instituições que figuram no processo. Existe um modelo padronizado de documento que dá origem ao primeiro despacho:

Requisitem-se informações aos arguidos. Manifestem-se o Advogado-Geral da União e o Procurador-Geral da República, no prazo comum de 5 (cinco) dias (art. $5^{\circ}, \S 2^{\circ}$ da Lei $n^{\circ} 9.882 / 99$ ). 
Um despacho pode ser mais ou menos uma decisão. Na maioria das vezes ele informa, por escrito, as providências que devem ser tomadas para o andamento do processo, o que pode ser um procedimento interno ou externo ao Tribunal. Os despachos dos ministros fazem com o que autos sejam deslocados para a Secretaria Judiciária, em setores específicos que têm por atribuição executar as determinações.

O despacho foi assinado pelo presidente no dia 21, encaminhando o processo à Seção de Comunicações. A leitura da decisão permite que os servidores materializem os comandos nela contidos através de procedimentos e documentos específicos. Informações são requisitadas por meio de oficio, destinadas à denominada parte passiva ou polo passivo. Manifestações são requisitadas por meio de mandados de intimações. Os registros de envio são anexados aos autos também como documentos, mas de um tipo diferente; são "documentos que documentam" (NADAI: 2013) o procedimento, e vários deles serão incorporados aos autos. Visman (2008) já destacava, em sua pesquisa sobre processos judiciais, essa dupla orientação da execução de um comando em um processo jurídico que, por um lado, gera um novo procedimento e, por outro, anota sua própria execução, evidenciando que um processo contém sua própria progressão (p. 8).

No dia 28/7 os autos da ADPF foram novamente encaminhados à Seção do Controle Concentrado e Reclamações. A Secretaria Judiciária é composta por várias salas (coordenações), para onde se destinam classes de processos diferentes. É possível identificar qual a especialidade de cada uma das salas pela cor dos processos nas mesas e nos armários. Todas as salas parecem ser revestidas por estantes em que se acumulam processos. No centro estão as baias dos funcionários, rodeadas de autos processuais, carimbos, canetas e seus computadores "decorados" com os post-its amarelos. Além das classes, que dividem os funcionários em setores distintos, o interior de cada sala o trabalho é dividido pela numeração final do processo. As pastas cor-de-rosa são de responsabilidade de apenas dois analistas judiciários. 


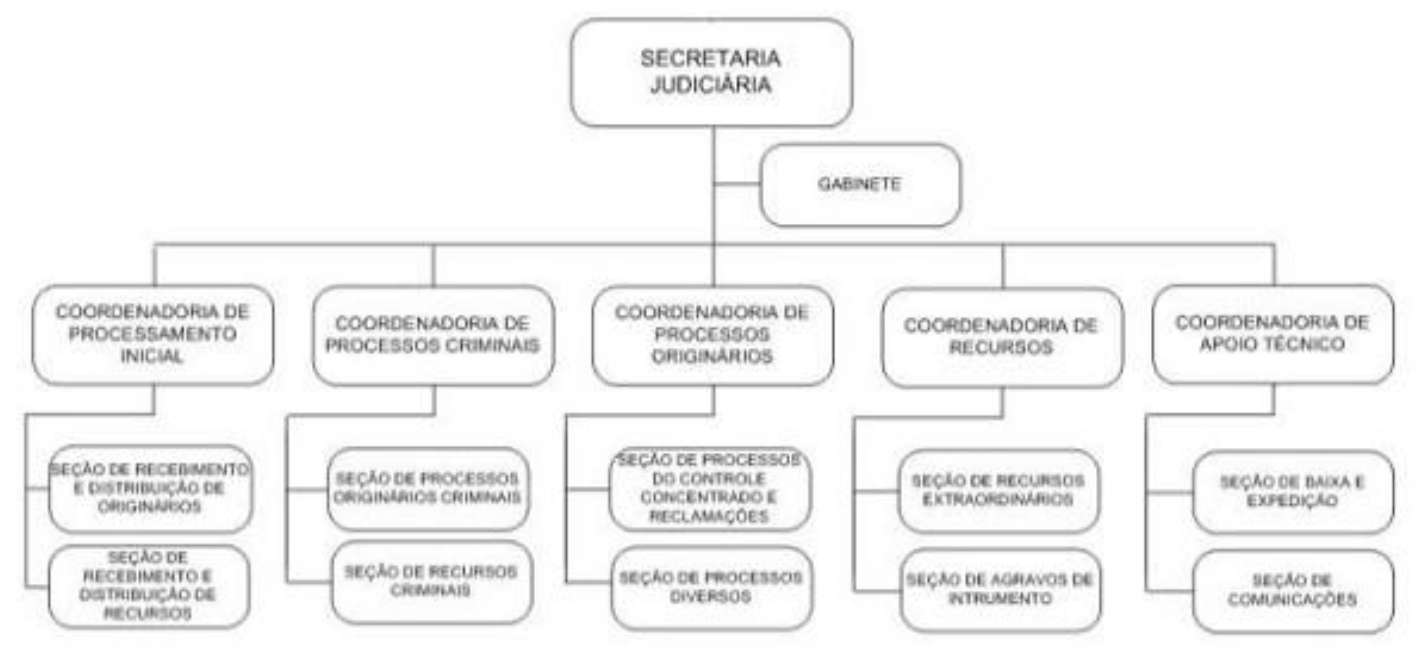

Figura 4 - Organograma da Secretaria Judiciária. Fonte: site STF.

$\mathrm{O}$ retorno à SEJ se deu por conta do recebimento das respostas ao despacho do gabinete. Outros três conjuntos de documentos foram anexados aos autos, e outra pasta cor-de-rosa foi aberta. Apesar de serem documentos independentes, pelo menos até serem anexados, os três trazem no timbre do papel o brasão da República. O primeiro identificando a Procuradoria Federal, como representante de todos os arguidos. Os outros dois identificando a Advocacia-Geral da União e o Ministério Público Federal como interessados. Quando esses documentos são anexados forma-se então o contraditório.

Embora sejam documentos parecidos, tanto na forma como no conteúdo, os novos documentos entregues irão ocupar posições distintas no interior do processo. Enquanto os arguidos pedem/ requerem, a PGR e a AGU manifestam-se/opinam, o que parece identificar afastamentos em relação ao objeto da ação. Trata-se de um tipo de opinião técnica emitida pelos órgãos.

Tendo todas as manifestações e petições no gabinete, o presidente então produz a primeira decisão do processo, que se refere tão somente à medida cautelar, indeferida no dia 31/7: 
Com essas breves considerações sobre o tema, indefiro o pedido de medida cautelar, ad referendum do Plenário.

Publique-se.

Comunique-se.

Ante o término do período de férias do Tribunal, proceda-se à livre distribuição do processo.

Brasília, 31 de julho de 2009.

Ministro GILMAR MENDES

Presidente

(art. 13, VIII, RI-STF)

A partir da ordem expressa do ministro, a decisão foi então publicada no Diário da Justiça, momento a partir do qual a decisão passa a ter eficácia, e o processo seguiu para a seção de distribuição.

Conforme o regimento interno do STF, art. 66, a distribuição é feita por sorteio ou prevenção. No ultimo caso, os servidores identificam a questão jurídica dos autos e buscam processos conexos no banco de dados. Quando existem outros processos com objetos semelhantes em algum gabinete, o novo processo deverá ser encaminhado ao mesmo. A distribuição convencional se dá mediante sistema informatizado, acionado automaticamente em cada classe de processo.

Quando distribuído, o sistema gera um relatório e uma ata, disponibilizada pelo Tribunal para acesso dos advogados. Ainda assim a distribuição pode ser contestada pelas partes, também por meio de petições. Os critérios que fazem conexões entre os processos costumam ser diferentes do ponto de vista dos advogados e dos servidores da distribuição. A partir desse momento, as questões procedimentais do processo se tornam discutíveis, tendo em vista que o relator de um caso deverá guiar os votos de 
todo o colegiado. A escolha do ministro é importante, ou até determinante para o resultado.

Nessa seção, eventualmente é possível identificar impedimentos ${ }^{17}$ dos juízes, embora não seja papel da seção afastar um ministro do processo, caso ele mesmo não tenha declarado seus impedimentos ao Tribunal. Existem listas de impedimento entregues pelos ministros à seção, e quando não observadas, podem gerar constrangimento ao ministro, pois os advogados das causas conhecem as limitações impostas pelas listas e deverão cobrar do ministro, caso um processo chegue a seu gabinete de forma imprópria.

Existem várias razões para que um ministro se declare impedido para julgar um processo; tais razões dependem de relações estabelecidas ou com os objetos ou com os sujeitos das ações. Ao se declarar impedido, o ministro envia ofício ao presidente do Tribunal, informando-o de sua restrição.

\subsection{OS GABINETES E A SECRETARIA}

Como vimos, nesse primeiro momento os autos circulam entre a Secretaria Judiciária - e suas inúmeras seções - e o gabinete do ministro responsável. As rotinas de processamento envolvem dezenas de microprocedimentos (LATOUR: 2002), operados por funcionários de diferentes setores. A maior ou menor autonomia desses procedimentos não depende exclusivamente do lugar em que se fazem as operações, nem mesmo do tipo de operação que será realizada, mas do tipo de processo que se está produzindo. Nesse sentido, o trabalho dos gabinetes e da Secretaria Judiciária guarda semelhanças procedimentais, ainda que vistos como lugares completamente

\footnotetext{
${ }^{17}$ Em regra, um juiz deve se declarar impedido quando participou do processo que será julgado como advogado ou como parte, não pode ele ocupar duas posições diferentes no mesmo processo, ou ainda quando o julgamento envolver parentes próximos. Também consta na Lei Orgânica da Magistratura, que um juiz não estaria apto a julgar amigos íntimos ou inimigos capitais.
} 
distintos. Na realidade, grande parte dos analistas e técnicos que trabalham nos gabinetes desconhece os expedientes da SEJ. A relação entre esses dois setores é restrita a troca de processos, que saem dos gabinetes com determinado status e retornam modificados.

Um dos servidores entrevistados relata a diferença entre o que chama de "dois universos", aquele da Secretaria Judiciária e o universo dos gabinetes:

São dois lugares muito diferentes. Dois universos que não se reconhecem. O trabalho da Secretaria Judiciária prepara e organiza todo processo de acordo com o que diz a lei e o regimento interno. Cada um tem sua função nessa organização, e ninguém pode errar, porque qualquer erro compromete todo o processo. Nos gabinetes também não se pode errar, mas quando um processo chega ao gabinete, são realizadas outras operações, que são burocráticas também, mas que aparecem de outra maneira, como se não fossem. Os gabinetes são o lugar de prestígio dentro do Tribunal, porque se trabalha junto com o ministro ${ }^{18}$.

O "ninguém pode errar", nem a secretaria nem o gabinete, parece indicar que a burocracia judicial não se separa do processo de tomada de decisão. O trabalho da Secretaria Judiciária, então, também atua com/sobre o direito. No entanto, as rotinas de administração dos autos processuais são vistas como diferentes nos gabinetes e na secretaria do Tribunal. Mello Souza (2012) chama atenção para os dois tipos de racionalidades que operariam no STF: a racionalidade jurídica e a administrativa. Conforme a autora:

${ }^{18}$ Entrevista junho de 2012. STF 
Era para isso que queríamos apontar quando afirmamos que as decisões eram influenciadas pela conjunção de dois tipos de racionalidade: a administrativa e a jurídica. Tais racionalidades trabalham, cada qual, com seus objetivos e sua concepção sobre eficiência - concepção e objetivos que são diferentes em cada uma das racionalidades. Enquanto a racionalidade jurídica busca a aplicação do direito ao caso concreto, à obtenção de uma decisão dentro dos limites estipulados pelo direito, a racionalidade administrativa está focada na resolução de mais casos no menor tempo possível. (p. 41).

Ao acompanhar a circulação dos processos e a atuação dos diferentes setores, não me pareceu existir uma separação radical entre esses dois tipos de racionalidade. A forma como se administra o processamento está implicada na forma como se decide. Em certa medida, todos que trabalham para a decisão também a constituem. A decisão circula então, na medida em que circulam os autos.

Conforme me foi dito, a Secretaria Judiciária recebe, prepara e remete o processo. Atesta seus deslocamentos e faz cumprir as determinações dos gabinetes em cada ato processual. "Todo trabalho que fazemos aqui é técnico. Somos nós que fazemos os processos" - dizia-me uma das funcionárias da SEJ, afirmando que a secretaria "materializa" as ordens emitidas pelos gabinetes e que os analistas da SEJ são "instrumentos" para o correto andamento de um processo. Quando "fazem processos", incorporam documentos, realizam procedimentos de classificação e circulação, dão cumprimento às decisões, enviam e recebem outros documentos, acompanham os prazos legais e remetem os autos "conclusos ao relator". O que significa dizer que ele já pode decidir.

Todo esse trabalho é considerado técnico no sentido de que "apenas aplicam" os procedimentos pertinentes a cada caso. A funcionária também falava em maior autonomia no trabalho da secretaria, categoria cujo significado contextual diz respeito à certa independência em relação aos ministros. Os procedimentos realizados na 
secretaria têm autonomia em relação aos ministros na medida em que o juiz apenas dá o comando. O que será produzido a partir desse documento enviado faz parte da expertise dos analistas e técnicos da secretaria.

Técnica e autonomia aparecem também no discurso dos funcionários dos gabinetes, embora com outros significados que tentarei esclarecer a seguir. Nos gabinetes, a preparação do processo segue as regras determinadas por cada ministro e seus assessores. Os funcionários trabalham para o ministro e não para o Tribunal. Os atos processuais da Secretaria Judiciária são todos registrados e fazem parte do processo. Já nos gabinetes toda preparação é apenas interna, ou seja, apenas uma parte das ações desenroladas nos gabinetes acrescenta ao processo mais folhas.

Enquanto documentos devem sair da SEJ assinados e carimbados por funcionários específicos, a única assinatura que conta nos gabinetes é a do próprio ministro, as intervenções nos processos dos analistas e assessores dos gabinetes são realizadas como se fosse o ministro. Nos gabinetes toda a estrutura está marcada pela divisão do trabalho entre funcionários de maior ou menor confiança do ministro, os mais próximos e os mais distantes, em um jogo de competências e experiência diferentes. Os cargos nos gabinetes são divididos entre estagiários, técnicos, analistas e assessores, cada um deles com tarefas específicas no gerenciamento e preparação dos autos, que podem ser mais ou menos autônomas, mais ou menos técnicas, em oposição às funções de maior autonomia em relação à decisão.

O trabalho dos servidores nos gabinetes é espelhado no ministro. Entre as competências requisitadas estão conhecer a forma como cada juiz trabalha, como pensa, quais termos gosta ou não de usar, qual seu estilo de texto, quem são seus doutrinadores de referência. "O ministro não usa expressões em outras línguas, se elas existem devem ser traduzidas. Sua excelência não gosta também de usar "resta claro" não sei dizer porquê mas não usamos resta claro", me dizia um analista judiciário. Esse tipo de conhecimento permite que os funcionários antecipem muito do trabalho, por meio de uma "prefiguração" que reproduz de modo mais ou menos fiel as ações dos ministros. Existem ainda nos gabinetes, ou na maioria dos gabinetes, juízes auxiliares escolhidos e trazidos pelos ministros para ajudá-los nos processos. Apenas os ministros Marco Aurélio e Celso de Melo, abriram mão da requisição. 
A divisão do trabalho nos gabinetes é tratada por Mello Souza (2013) em termos de prestígio:

Há uma hierarquia de prestígio com diversos níveis de estamento (DUMONT, 1985; 1995). Para essa outra hierarquia não importa se a lei atribuiu a competência ao analista, ao técnico ou ao terceirizado, etc. Quem determina qual atribuição cada funcionário recebe são os ministros. (p. 100).

Os ministros, desse modo, podem reconhecer capacidades de funcionários, a depender de sua atuação nos processos, e reajustar suas funções, o que Mello de Souza chama de "distribuição de prestígio". Como quando um funcionário é chamado à sala do ministro para participar de alguma reunião e cuja opinião será levada a sério.

Ao reconhecer competências, os ministros transformam as funções dos servidores independentemente do que diz o regimento, dando a eles atuações de maior responsabilidade. No gabinete do ministro Marco Aurélio, por exemplo, o oficial do gabinete, responsável por todo o gerenciamento processual, começou como assistente de plenário e, segundo ele, ao longo dos anos foi ganhando a confiança do ministro e assumindo, então, funções de maior responsabilidade.

Quanto mais um técnico ou analista produz, mais responsabilidade carregam e menos o seu trabalho será revisado por outros colegas, diminuindo assim a distância entre o que se produz e o ministro. As hierarquias dos gabinetes não são fixas e regimentais, mas dependem da capacidade produtiva dos funcionários. Como já destacou Pottage (2001): “A agência das pessoas é, portanto, entendida em termos de uma linguagem de trabalho, ou de produtividade" (p. 117). De todo modo, estando mais ou menos próximos aos ministros, o protocolo das relações deve sempre ser mantido. Ninguém está autorizado a chamar o ministro pelo nome. 
$\mathrm{Na}$ Secretaria Judiciária, existem também assimetrias que marcam a divisão do trabalho e são, sobretudo, funcionais e regimentais, relacionadas aos cargos que os servidores podem ocupar - como chefes de seção, coordenadores ou secretários -, mas também aos tipos de processos que cada um pode gerenciar. Assimetria aqui, no entanto, nem sempre é convertida em hierarquia.

As primeiras divisões de trabalho levam em conta o regime de contratação dos funcionários, como estatutários, terceirizados e estagiários. Processos potencialmente mais difíceis, como os do controle concentrado, são destinados aos funcionários concursados $^{19}$, detentores de fé pública e com mais experiência no manejo dos procedimentos. As plataformas tecnológicas de registro e deslocamento dos processos também liberam recursos diferentes para cada servidor, o que permite ou restringe determinadas ações. Existem ainda concursos internos para promover funcionários, colocando-os em posição de maior responsabilidade.

Com isso em vista podemos voltar à circulação da ADPF 186. Depois de ganhar um relator através da distribuição, o processo entra na denominada fase de instrução, que no nosso caso irá envolver procedimentos especiais, dada a natureza da controvérsia judicial apresentada. As ADPFs, como potencialmente apresentam casos difíceis, já são em si mesmas ações especiais, o que se faz notar, por exemplo, na numeração da classe, ainda na casa dos três dígitos. A maioria dos processos que chegam aos gabinetes são pastas amarelas e azuis: agravos e recursos extraordinários.

${ }^{19}$ Vale aqui também uma breve nota. Os servidores do STF recentemente apresentaram ao presidente da corte uma proposta de carreira própria do Tribunal. Conforme o documento: "Se o ápice da carreira de qualquer magistrado é chegar ao Supremo Tribunal Federal, por que não ser esse também o anseio dos servidores do Poder Judiciário/". A justificativa para o pleito reside na maior responsabilidade dos servidores deste Tribunal em relação a outras carreiras no sistema judiciário, além das regras próprias a que se submetem os servidores do STF, como o vestuário obrigatório - terno e tailleur. 
Sendo ações diferenciadas, para as ADPF existe uma série de instrumentos que podem viabilizar as decisões, além de uma série de requisitos de admissibilidade. Uma ADPF se constitui como uma forma de evitar ou reparar lesão a preceito fundamental resultante de ato do poder público; só pode ser apresentada ao STF caso não exista outro meio eficaz de resolver a suposta lesão, ou seja, quando uma questão não pode ser resolvida por meio de outro tipo de processo, uma ADI por exemplo. Uma ADPF é também uma ação que requer a declaração de inconstitucionalidade como uma ADI, no entanto, se diferencia porque os próprios termos constitucionais se diferenciam, apontando para uma hierarquia interna à Carta Magna. Uma ADPF não se refere a qualquer termo constitucional, mas àqueles que são considerados preceitos fundamentais.

Nenhum desses requisitos é automático, ao contrário, dependem do que o Tribunal entende como preceito fundamental e do que entende como outro meio capaz de resolver a questão. O conhecimento da ação pelos ministros nunca está dado a priori. Em alguns casos, como a ADPF 186, os advogados preveem uma possível inadmissão da forma utilizada, requerendo a transformação da ADPF em ADI, caso isso aconteça.

De modo geral, um processo não é resolvido logo que chega aos gabinetes. Existe uma fila de processos que se acumulam nas estantes, aguardando sua hora de chegar à mesa de um dos funcionários. Os analistas aguardam que todos os procedimentos sejam cumpridos e todos os documentos sejam entregues. A atuação do gabinete depende do que é produzido por outros atores que não estão no Tribunal. Os processos quando remetidos a PGR ou aos advogados das causas, ficam "trancados", dependendo de sua devolução ao gabinete. Ainda que existam prazos para devolução de um processo ao tribunal, eles nem sempre são cumpridos pelas partes. Algumas vezes as partes ou a PGR, "seguram" o processo com vistas a também "segurar" a decisão.

Um processo no STF é feito de movimento e circulação, mas também de pausa, muitas vezes necessária para que a decisão se produza. No caso das questões “relevantes", essas pausas são menos visíveis dado que existe uma grande quantidade de informações anexadas aos autos e um grande número de interessados na questão. Desse modo, o processo não para de circular, de sair do gabinete em direção à 
secretaria, e cada vez que os autos saem dos gabinetes eles devem voltar ainda maiores.

Se o processo é o espaço da dúvida, como me disse o ministro Marco Aurélio quando o entrevistei ${ }^{20}$, essa dúvida é produzida com o acúmulo de informações, e um documento a mais pode fazer toda a diferença nos julgamentos. Conforme Latour (2010), a operação do direito e os procedimentos técnicos se voltam a sustentar uma "dúvida" pelo maior tempo possível como garantia de que a decisão não foi precipitada, "arbitrária" ou "superficial" (p. 221). Enquanto as pastas dos volumes dos autos não estiverem amassadas, riscadas, quase se desfazendo - indicativos de que aquele processo passou pela mão de várias pessoas, foi revirado, visto e revisto -, o processo não está pronto para ser julgado. O processo então tem "substância", no sentido que passou por várias mãos.

No caso da ADPF 186 e de outros processos com objetos "delicados", existem, ainda, formas especificas previstas e viabilizadas pelo relator que possibilitam a abertura do processo a outros interessados que não apenas as partes, como as audiências públicas e o instituto "amigos da corte" para compor uma decisão e objetivam dar aos juízes da corte, em especial ao relator do processo, informações para além daquelas prestadas pelas partes da ação. Esses instrumentos são previstos de acordo com a relevância das controvérsias, que são estabelecidas exclusivamente pelo relator como "dono do processo", nos termos da Secretária Judiciária. Tudo que é dito nas audiências se transforma em notas taquigráficas e compõe os autos processuais.

\footnotetext{
${ }^{20}$ Entrevista realizada em junho de 2012. STF
}

21 "Amigo da Corte". Intervenção assistencial em processos de controle de constitucionalidade por parte de entidades que tenham representatividade adequada para se manifestar nos autos sobre questão de direito pertinente à controvérsia constitucional. Não são partes dos processos; atuam apenas como interessados na causa. Plural: Amici curiae (amigos da Corte). 
A decisão sobre quem pode ou não intervir no processo é encaminhada por despacho e marca uma das passagens entre os universos das questões discutíveis e indiscutíveis. Não bastam aqui apenas as palavras de ordem (manifestem-se, publique-se), com o número da lei entre parênteses, como no caso do primeiro despacho. Agora a lei sai dos parênteses e é citada por extenso e qualificada pela jurisprudência:

De acordo com o art. $6^{\circ}$, parágrafo $1^{\text {o }}$, da Lei 9.882/1999: "Se entender necessário, poderá o relator ouvir as partes nos processos que ensejaram a arguição, requisitar informações adicionais, designar perito ou comissão de peritos para que emita parecer sobre a questão, ou ainda, fixar data para declarações em audiência pública de pessoas com experiência e autoridade na matéria". Sobre a admissão de amicus curiae, menciono o pronunciamento do Ministro Celso de Mello, nos autos da ADI 3.044/DF, de sua relatoria: "a intervenção do amicus curiae, para legitimar-se, deve apoiar-se em razões que tornem desejável e útil a sua atuação processual na causa, em ordem a proporcionar meios que viabilizem uma adequada resolução do litígio constitucional". Ressalto ainda que a admissão de amicus curiae configura circunstância de fundamental importância, porém de caráter excepcional, e que pressupõe, para se tornar efetiva, a demonstração do atendimento de requisitos, dentre eles, a adequada representatividade daquele que a pleiteia. (Despacho do ministro Ricardo Lewandowksi)

Concluídos todos os procedimentos relativos à instrução do processo, a decisão pode então ser produzida. De modo geral, os votos e as decisões começam a partir de minutas elaboradas pelos analistas dos gabinetes. Os autos saem dos armários e chegam às mesas dos funcionários de acordo com suas competências. Os primeiros funcionários que preparam os processos realizam uma primeira pesquisa no banco de 
dados do próprio gabinete, com o objetivo de encontrar conexões entre o novo caso e os casos já decididos. Encontrando objetos iguais à decisão é padrão. "Veja aqui", me mostrava um dos funcionários do gabinete, abrindo um dos processos em sua mesa:

- Primeiro eu marco com essas fichinhas as partes do processo, está vendo? Essas são as peças processuais. Tudo precisa estar no processo, senão pode dar problema. Essas formalidades são tão importantes quanto o conteúdo. O substabelecimento, a autenticação das cópias. Eu abro o processo marcado, dou uma lida (me falava enquanto folheava os autos). Depois venho aqui (abriu uma aba no computador) e verifico se já existe alguma decisão do Ministro sobre a matéria. Se já existe, eu reproduzo aqui (mostra outra aba do navegador). Mas isso é só o começo. Os analistas ainda vão verificar, corrigir e apresentar ao Ministro, que pode mudar tudo, se quiser. Vou te mostrar outro processo [ levantou da cadeira e se dirigiu a estante trazendo consigo um processo]. Nesse caso aqui, o objetivo desse recurso é que o ministro analise novamente as provas, ele cai pela $279^{22}$. Aqui no sistema podemos ver outras decisões que usam a 279, esse recurso é igual a todos esses aqui. Mas é o ministro quem decide.

$\mathrm{O}$ "cai na 279" a mim parecia quase uma palavra mágica que colocava fim naquele recurso com centenas de páginas. No entanto, o recurso não estava resolvido, seria

${ }^{22}$ Se referia a súmula 279 do STF que diz: Para simples reexame de prova não cabe recurso extraordinário. Uma súmula é uma síntese de todos os casos, parecidos, decididos da mesma maneira, colocada por meio de uma proposição direta e clara. A súmula não possui caráter cogente, servindo apenas de orientação para futuras decisões. (verbete STF) 
revisado, passando pela mão de outros analistas que deveriam conferir se de fato podia ser aplicada a barreira do "279" ao recurso e ainda precisaria passar pelo ministro. Os analistas repetem sempre a frase "mas é o ministro quem decide", tentando reafirmar que nenhuma decisão é tomada pelos funcionários. Em certa medida, porque sempre existe um contato do ministro com processo, ainda que seja apenas para assinar a decisão. Não existe decisão em um processo até que o ministro assine o documento, o que não significa que ele analisou os autos, mas que apenas o ministro tem autoridade para transformar uma minuta em uma decisão.

Objetos diferentes dão sequência aos procedimentos, e outras pesquisas serão realizadas. Ao analisar a petição inicial, o servidor encarregado vai anotando palavras-chaves em um bloco de notas em cima da sua mesa. Abre em seguida o banco de dados e digita as palavras anotadas. Cada uma dessas palavras identifica diversos processos que também têm seus números anotados. Assim vão se formando conexões entre os casos, que produzem conexões entre as decisões. Essa busca dos precedentes que podem sustentar um posicionamento tem algumas peculiaridades. Dependendo da palavra-chave que se digite, ou do número processual do assunto, o sistema encontra precedentes diferentes. Ainda no acórdão tomado como precedente, o funcionário encontra outros números de processos relacionados utilizados naquele caso que possivelmente também serão anexados à nova decisão. Um precedente atrai outros que estão no mesmo dispositivo decisório. Existe aqui o que Soares e Melo e Souza (2014) denominaram de "rede de precedentes". Os bancos de dados acessados pelos funcionários do Tribunal são os mesmos, existindo alguns específicos para determinada classe processual como ADI, que tem um banco de dados exclusivo. No entanto, como bem demonstraram Soares e Melo e Souza, o próprio sistema contém limitações e dependendo dos critérios de busca encontram-se casos diferentes. Conforme os autores:

O sistema de pesquisa, que tanto nós quanto as assessorias (que fazem as minutas dos votos) dos ministros utilizam, tem uma abrangência limitada. Não conhecemos as limitações técnicas, e estas dependem tanto dos mecanismos de busca quanto da estrutura do 
banco de dados. Na prática, se, por alguma razão, o assessor considerar que a pesquisa no seu sistema não é suficiente, ele recorre à sessão de pesquisa de jurisprudência, com recursos mais avançados, e, portanto, capaz de pesquisas mais sofisticadas. No entanto, nem um nem outro processo de pesquisa garante que as assessorias de diferentes ministros vão obter os mesmos precedentes, mesmo se estiverem trabalhando com casos semelhantes. A razão disso é que para conseguir os mesmos julgados seriam necessários os mesmos critérios de busca. A mudança de uma palavra ou, dependendo do software utilizado, a alteração da ordem dos termos traz resultados diferentes. (p. 14)

Existe uma estratégia dos funcionários que também opera na busca dos precedentes. É comum que o primeiro critério de busca seja o nome do advogado da petição. Foi-me relatado que um mesmo profissional, em casos conexos, utiliza uma petição modelo; assim é possível aos funcionários encontrar os precedentes quase exclusivos de um determinado advogado. Também devo destacar que a memória dos funcionários opera na busca dos precedentes. Algumas vezes funcionários com processos em suas mesas digitavam de memória o número de outro processo que sabiam tratar-se de objetos supostamente semelhantes. Existe também a pesquisa da doutrina relacionada ao caso na mesa do analista. Por vezes a doutrina que será usada no novo caso também está no processo anterior tomado como precedente. Quando o processo exige uma pesquisa com maior abrangência, os analistas solicitam a um setor do tribunal fora do gabinete realizem esse levantamento.

Os recursos de software utilizados nos gabinetes facilitam a produção das decisões porque trabalham com padrões de formatações nos quais basta os assessores inserirem as especificidades de cada processo. Cada um dos funcionários dos gabinetes tem um tipo de acesso aos bancos de dados contidos nos programas; o acesso ilimitado é apenas do ministro, embora não seja ele que utilize as ferramentas. A rigor, são os chefes de gabinete que usam as chaves virtuais de acesso dos ministros, e estes entram no sistema apenas para assinar eletronicamente suas decisões, às vezes, várias de uma 
só vez. Mesmo com uma série de recursos tecnológicos desenvolvidos especialmente para a gerência dos processos, a tecnologia amplamente utilizada no Tribunal está no uso dos post-its, que são colados tanto nos processos quanto na mesa e nos computadores dos funcionários; eles identificam tarefas a ser realizadas, lugares e números de processos de referência.

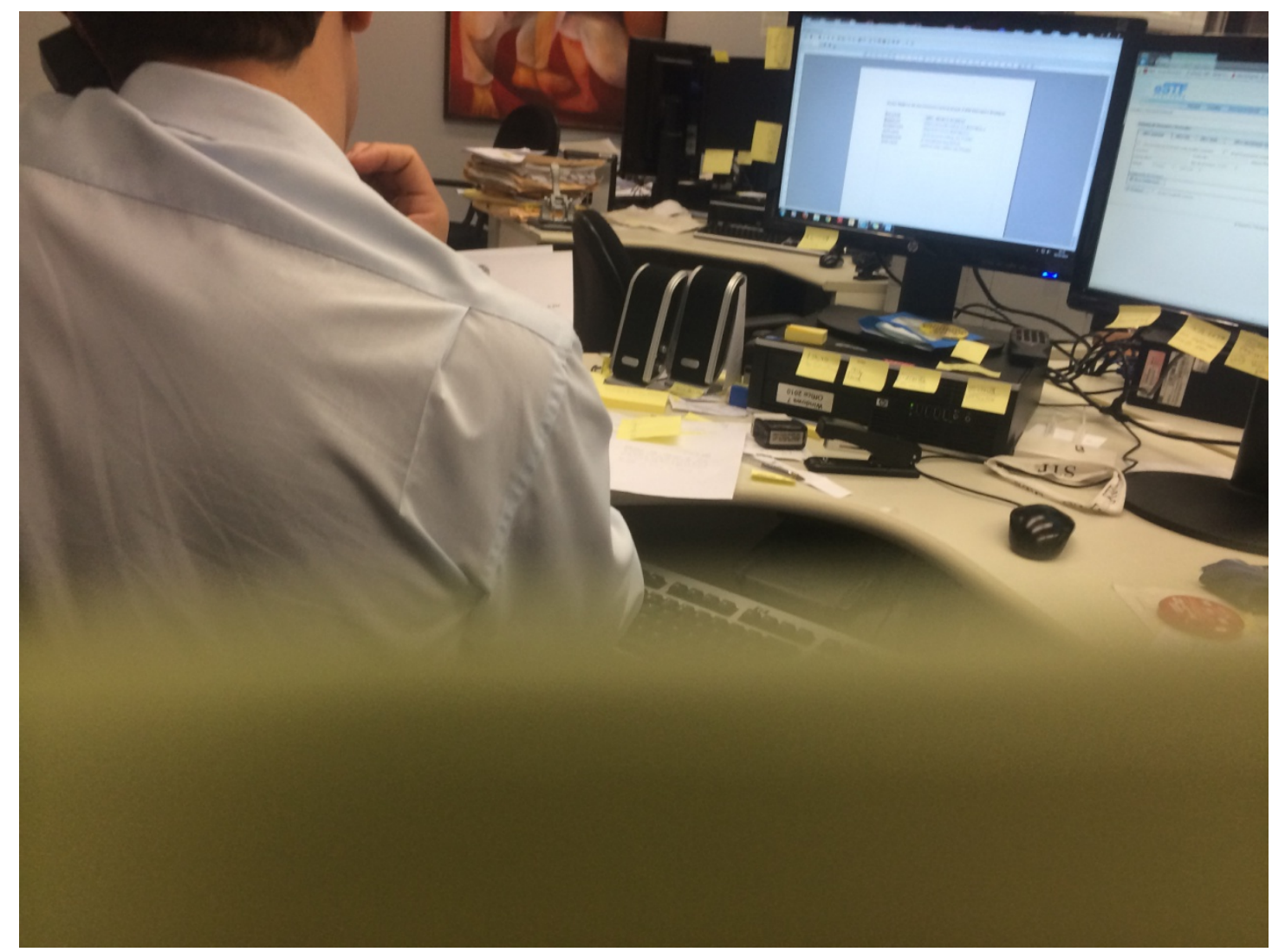

Figura 5 - Foto do Gabinete

A partir das pesquisas, minutas de decisão vão sendo produzidas e inseridas no sistema, com uma marca d'água na página “em elaboração", e seguem para que sejam revisadas antes que cheguem ao ministro. Junto com as minutas são produzidos relatórios que sintetizam as informações e argumentos dos autos. Os analistas selecionam ou extraem nos termos locais os argumentos mais importantes de cada petição, juntando-os no mesmo documento. De certa forma, ainda que um ministro possa ler grande parte do processo, ele trabalha a partir dos relatórios dos analistas. 
Na realidade, ninguém lê todo o processo, porque nem todos os documentos inseridos nos autos destinam-se à leitura; alguns deles precisam apenas constar, pois têm papel meramente formal, ao mesmo tempo todo mundo lê o processo, no fluxo de pessoas e procedimentos que gerenciam os autos.

As minutas são vistas como sugestões de votos e permitem um tipo de debate entre os assessores e analistas com o ministro por meio das revisões. Quando os ministros analisam as minutas, por vezes, pedem correções, requisitam outras pesquisas ou minutas em sentido contrário àquele apresentado. A capacidade de uma minuta se tornar o voto depende de alguns fatores. O primeiro deles, como já dissemos, está nos processos repetidos, sendo as minutas um tipo de padrão de decisão, ou seja, o ministro já decidiu aquela questão. Outros casos envolvem áreas específicas de conhecimento jurídico, o que garante a alguns funcionários maior intervenção na decisão do ministro, tendo em vista que um juiz não tem o domínio de todas as áreas do direito, por isso se cerca de funcionários que podem preencher essas lacunas. Ainda existe a possibilidade de o ministro mudar a posição durante o julgamento; nesse caso pode pedir que uma nova minuta seja feita rapidamente ou pode declarar seu voto apenas com a anotações feitas em plenário. No entanto, isso só acontece em processos "comuns"; nos mais "difíceis" os ministros sempre levam os votos preparados.

A complexidade dos processos atrai a competência dos assessores mais próximos ao ministro, e mais especializados. São esses analistas e assessores, alguns com cargos de confiança indicados diretamente pelo ministro, que vão auxiliá-lo a produzir sua decisão a partir de outras conexões e analogias que não somente aquelas apresentadas pelos precedentes. É comum que ministros com carreira docente em universidades tragam para o gabinete seus orientandos de pós-graduação. Existem também funcionários de confiança herdados de ministros que se aposentam. A expertise procedimental desses funcionários auxilia os novos ministros a estabelecer seu movimento processual.

Passei algumas semanas dentro de um gabinete tentando entender a dinâmica de produção dos processos, ao lado de assessores e técnicos, e principalmente acompanhando o trabalho do chefe de gabinete. 
O "chefe", como era chamado, sentava-se a uma mesa um pouco escondida, atrás de uma parede, entre os técnicos que ocupavam a primeira parte da sala e os analistas que ocupavam uma parte separada da sala, ao lado do gabinete do ministro. No chão, ao redor da sua mesa, havia pilhas e mais pilhas de autos processuais. Era ele que controlava todo o fluxo do processamento. Enquanto tentava se mover, saltando as pilhas a seu redor, me dizia que grande parte dos casos que estava ali não deveria estar. Que a "vocação" da corte não era julgar "ladrão de galinhas", e que esperava que houvesse uma mudança que impedisse a "subida" desses processos "irrelevantes". Os casos que não deveriam estar ali ocupando espaço e tempo do tribunal são parecidos com os identificados por Yngvesson (1998) como "garbage case"23. A reclamação relacionada aos casos que "não deveriam estar lá" é compartilhada também pelos ministros da corte, que vez ou outra reivindicam mudanças na legislação visando restringir o acesso ao Tribunal. Uma questão "relevante" para o Tribunal segue mais ou menos as indicações apontadas por Boltanski (1991) nas denúncias públicas. Segundo o autor, as operações que fazem denúncias públicas são aquelas que permitem a passagem do singular para o geral, do individual para o coletivo. No entanto, as "pequenas" questões podem abrir grandes grande debates, ainda que não seja essa a expectativa.

Concretamente, existem modos que permitem medir a relevância de uma questão judicial. Anexar uma série de decisões de outros tribunais de instâncias inferiores parece acrescentar importância à questão, pois a falta de uniformidade dos entendimentos jurídicos sobre o tema só poderia ser dirimida definitivamente a partir do pronunciamento dos ministros. O número de pedidos para ingressar no processo na qualidade de amicus curiae funciona também como termômetro.

${ }^{23}$ Conforme a autora, na corte de Massachusetts existe grandes quantidades de casos submetidos ao tribunal que tratam de questões consideradas insignificantes. Ao excluir esses casos, o tribunal não apenas se protegeria de questões "irrelevantes" como configuraria sua própria autoridade a partir de um sistema que classifica o que cabe ou não àquele tribunal. 
Para gestar o mar de processos que chegam aos gabinetes, uma média de cem por semana, os analistas desenvolvem diversas práticas procedimentais que viabilizem um movimento processual adequado. Caso os técnicos não estejam atentos, um processo pode entrar no gabinete sem que se saiba da presença dele, e pode permanecer parado tempo demais, de modo que o objeto do pedido seja "prejudicado", termo que me parece indicar que a vida deu conta de resolver a questão.

Tentando sintetizar o funcionamento do gabinete, um dos analistas:

Cada gabinete é um mini-Supremo. Os processos todos chegam e são recebidos e cadastrados no sistema do gabinete. Depois, cada parte é separada e marcada, para que se saiba em que página está cada uma das peças. Separado, um analista faz as pesquisas referentes àquele processo e formula uma minuta, que é novamente conferida e corrigida para ser assinada; depois, mais uma vez tudo é conferido para ser liberado. Parece simples, mas cada ação aqui é de grande responsabilidade, nada é feito de uma hora para a outra. Um processo leva tempo, especialmente os casos mais difíceis. O gabinete prepara tudo, mas quem decide é o ministro ${ }^{24}$.

Enquanto permanecia sentada, ao lado do chefe, conseguia visualizar a complexidade que envolve um processo, pelo movimento das pessoas que sentavam e levantavam, carregando volumes e mais volumes de autos processuais de um lado para o outro. Traziam pilhas de papéis, que eram as decisões impressas, assinadas pelo ministro e que deveriam então ser anexadas aos seus respectivos processos. A cada instante tocava o telefone; quando estava em sua mesa, era o próprio chefe que atendia. Normalmente eram advogados do outro lado da linha que buscavam saber o

${ }^{24}$ Entrevista/ Conversa realizada em junho de 2012. STF. 
andamento de seus processos, tentando marcar audiência com o ministro. Rapidamente o chefe abria o computador, digitava o número e atendia à solicitação, ou perguntava em voz alta: "De quem é o processo [falava o número]?”; algumas vezes nem mesmo precisava realizar a pesquisa, pois sabia o andamento do processo de memória.

Era o chefe que esclarecia as dúvidas dos técnicos sobre o procedimento adequado de cada processo. Toda aquela aparente desordem era rigorosamente controlada. Cada um dos funcionários tinha uma meta de processos para "fazer" durante o dia. O "fazer processo" aqui significa identificar o objeto jurídico, separar as peças e os argumentos, definir os parâmetros jurisprudenciais ou pelo menos parte deles, produzir relatórios e minutas e liberar os autos para outros analistas. Na mesa dos analistas existem cópias da Constituição e dos códigos de processo penal e civil, que sempre são consultados, quando estão analisando os autos. Ainda é comum que busquem livros da biblioteca do STF, para esclarecer alguma dúvida do processo.

No final do dia, o chefe organizava os relatórios, memoriais e pesquisas, que seria enviada à casa do ministro e que voltariam ao gabinete no dia seguinte para que se desse encaminhamento às decisões. A casa dos ministros costuma ser uma extensão de seus gabinetes, alguns dos ministros trabalham em seus escritórios em casa nos dias em que não são realizadas sessões de julgamento, e alguns funcionários transitam entre o tribunal e a casa dos ministros, assim como alguns processos também realizam esse trânsito.

Uma dessas vezes em que estava no gabinete, ouvi uma conversa entre o chefe e um dos assessores. Discutiam um possível erro de digitação no nome da cidade para a qual deveriam mandar uma ordem de habeas corpus. O caso estava no gabinete porque o ministro relator fora voto vencido, passando a competência para a redação do dispositivo decisório ao ministro que inaugurou a divergência. A dúvida era se o nome da cidade era São João do Paraíso ou São Sebastião do Paraíso. Chegaram à conclusão de que o nome a cidade estava errado nos autos. Perguntei se ligariam para o outro gabinete avisando do erro, e sem hesitar o chefe me respondeu que não. 
Chefe: O erro não foi nosso.

Andressa: Mas vocês sabem que pode estar errado, e não vão avisar para que seja corrigido? Se a ordem de habeas corpus for para outra cidade, o que acontece?

Chefe: Não acontece nada. Eles vão perceber que está errado, mas eu não posso ligar para outro gabinete dizendo que eles erraram.

Andressa: Por que não pode?

Chefe: Pega mal, causa mal-estar. Imagina se eu ligo falando que eles erraram, aí o ministro pode achar que estamos nos intrometendo no trabalho do outro, não fica bem para o nosso ministro. Cada gabinete é responsável por aquilo que produz.

Entendi nessa hora que deveria dar uma interpretação literal ao que me disse o chefe quando se referiu a cada gabinete como um "mini-Supremo". O tribunal é um composto de vários microterritórios com suas próprias jurisdições. Não se corrigia uma indexação equivocada da Secretaria Judiciária, e tampouco um erro material de outro gabinete, porque isso significaria invadir outro território. A comunicação entre essas instâncias se dava pela troca de processos e pela troca de documentos. São eles que colocam em relação os diferentes setores do Tribunal. Percebi então que quando os autos são deslocados além dos documentos oficiais, que constam numerados existem papéis que circulam com recomendações de um setor para outro.

Até mesmo a uniformização das formatações dos documentos que saem do Tribunal foi "motivo de guerra" entre os gabinetes. Segundo um analista judiciário que me contou o ocorrido, a proposta que surgiu da presidência não foi bem aceita pelos gabinetes, "cada um queria manter sua própria formatação. Nem parecia que eram do mesmo lugar esses documentos". As formatações eram como se fossem as assinaturas dos gabinetes. 
$\mathrm{Na}$ realidade, disse-me ele, a "guerra" envolvia mais os assessores dos ministros do que os próprios ministros: "Aqui, assessor é como se fosse o próprio ministro". Não me surpreendi com a afirmação. Os assessores, no STF, fazem parte do ministro, são suas extensões. A atuação dos assessores nos processos equivale a atuação do ministro, diferente dos analistas da secretaria judiciária que são identificados e respondem pelos procedimentos que realizam.

Ainda durante o processamento, todos os argumentos da ação serão novamente repassados, dessa vez em um encontro ao vivo entre os advogados e o ministro relator, nas denominadas audiências. Oficialmente, pela primeira vez o relator poderá ouvir os advogados, receber deles outros documentos (memoriais), em uma conversa que não dura mais que 15 minutos. As audiências entre os advogados e os ministros são conhecidas pelos funcionários como embargos auriculares. É a última tentativa de convencer os ministros sobre a direção do voto, se é que depois de mais de 2 mil páginas de processo, como foi o caso da ADPF 186, resta ainda alguma coisa a ser dita. A primeira impressão que tive em relação à entrega dos memoriais foi que servia apenas como justificativa para encontrar os ministros, mas parece mais do que isso. Exatamente porque os processos são enormes e ficam nos gabinetes durante muito tempo, os memoriais, entregues mais proximamente ao julgamento, trazem de volta os argumentos principais de cada caso e reavivam a memória do ministro acerca da questão.

Ainda existem os memoriais entregues durante um julgamento - evidentemente quando ocupam mais de um dia. Nesses casos, os memoriais não trazem nada de novo ao caso, mas rearticulam os argumentos, exibem documentos dos autos que não foram mencionados nos votos até então proferidos; nesse caso todos os ministros recebem o documento, e não apenas o relator. No julgamento da Ação Penal 470, conhecida como processo de mensalão, os advogados usavam os memoriais para apresentar aos ministros pareceres técnicos de outros advogados especialistas em determinado tipo penal. Todavia, os memoriais não são uma peça processual que consta nos autos, nem mesmo passam pela Secretaria Judiciária. São a única parte dos autos que não são públicas e, portanto objeto debate entre as partes. 
Quando, então, não resta nada mais a ser feito pelo gabinete, o processo é liberado. Junto com os autos, o relatório de todo o processamento deve ser entregue aos outros ministros. A liberação não significa que o processo será prontamente julgado. Alguns demoram anos para entrar na pauta do plenário. Não cabe ao relator a decisão de quando um processo deve ser julgado, sendo a pauta prerrogativa exclusiva da presidência do tribunal.

A ADPF 186 foi entrou na pauta em abril de 2012, quase três anos depois de entrar no tribunal. Um tempo considerado pelos servidores como relativamente curto, mas não significa que o processo será arquivado. Depois do julgamento, os autos voltam ao gabinete do relator que deverá formular o acordão da decisão com base nos fundamentos enunciados pelos votos dos ministros e segue para sessão de composição de acordão ${ }^{25}$, que deverá incluir nos autos as notas taquigráficas, transformadas em documentos e conferidas pelos ministros, ao dispositivo decisório. O trâmite do acordão pode demorar anos, embora o prazo regimental seja de 20 dias. No caso da ADPF 186 até a última vez que pesquisei no site do tribunal, em julho de 2014, ele ainda não havia sido publicado. Quando o acordão não é publicado ele não se torna precedente e não pode ser citado.

A sequência de procedimentos de um acordão envolve todos os ministros do tribunal, que devem autorizar a transcrições taquigráficas feitas no setor especializado. Várias vezes o que disseram durante o julgamento é retirado pelos ministros e não deverá constar nos fundamentos da decisão, que são as sequências dos votos lidos e dos debates anexados. Junto ao acordão, a secretaria das sessões deve anexar a ata do julgamento também aprovada pelos ministros.

${ }^{25}$ Acórdão é a manifestação de um órgão judicial colegiado, que externa um posicionamento argumentado sobre a aplicabilidade de determinado direito. O texto é composto de quatro partes: ementa, relatório, motivação (ou fundamentação) e dispositivo, que são também seus requisitos essenciais segundo os arts. 458 e 563 do Código de Processo Civil. 
O que tentei demostrar nesse capítulo é que as práticas procedimentais e de documentação operam na circulação dos processos a partir de critérios distintos de classificação dos casos. O "fazer processos" inscreve determinada disputa de referências "estéticas", que não estão apenas nas normas jurídicas, mas, sobretudo na ideia de conhecimento técnico procedimental. Seguindo Latour ( 2010) o caráter legal dos enunciados produzidos no interior do tribunal são materializados nas passagens dos textos jurídicos, projetos de sentença e relatórios que compõem a decisão. A circulação dos processos implica diversos tipos de intervenções, que anexam aos autos documentos de diferentes qualidades e nos termos de Visman (2008) "estão na base da validade da operação jurídica direito" (p.15).

O "fazer processos", que na secretaria implica em classificar os autos e constituí-lo e nos gabinetes identificar os parâmetros para decisão, diluem o "poder" do juiz em um universo de distintos actantes (Latour 1999) que compõe uma extensa rede de produção de conhecimento. No argumento de Hermite (1998), para operação jurídica é necessário um distanciamento da "realidade" para reelaborar os objetos, integrandoos na rede de conceitos jurídicos e regras pré-existentes que não foram feitas especialmente para os casos. Na trajetória dos processos no STF, que inscreve uma demanda na lógica dos procedimentos é possível identificar que não existem pessoas com demandas ou problemas, o que existe são temas, assuntos jurídicos, modelos e precedentes que reelaboram os objetos dos processos, inserindo a decisão em uma racionalidade própria ao universo jurídico. Nesse sentido, o que tramita no tribunal são questões jurídicas. 


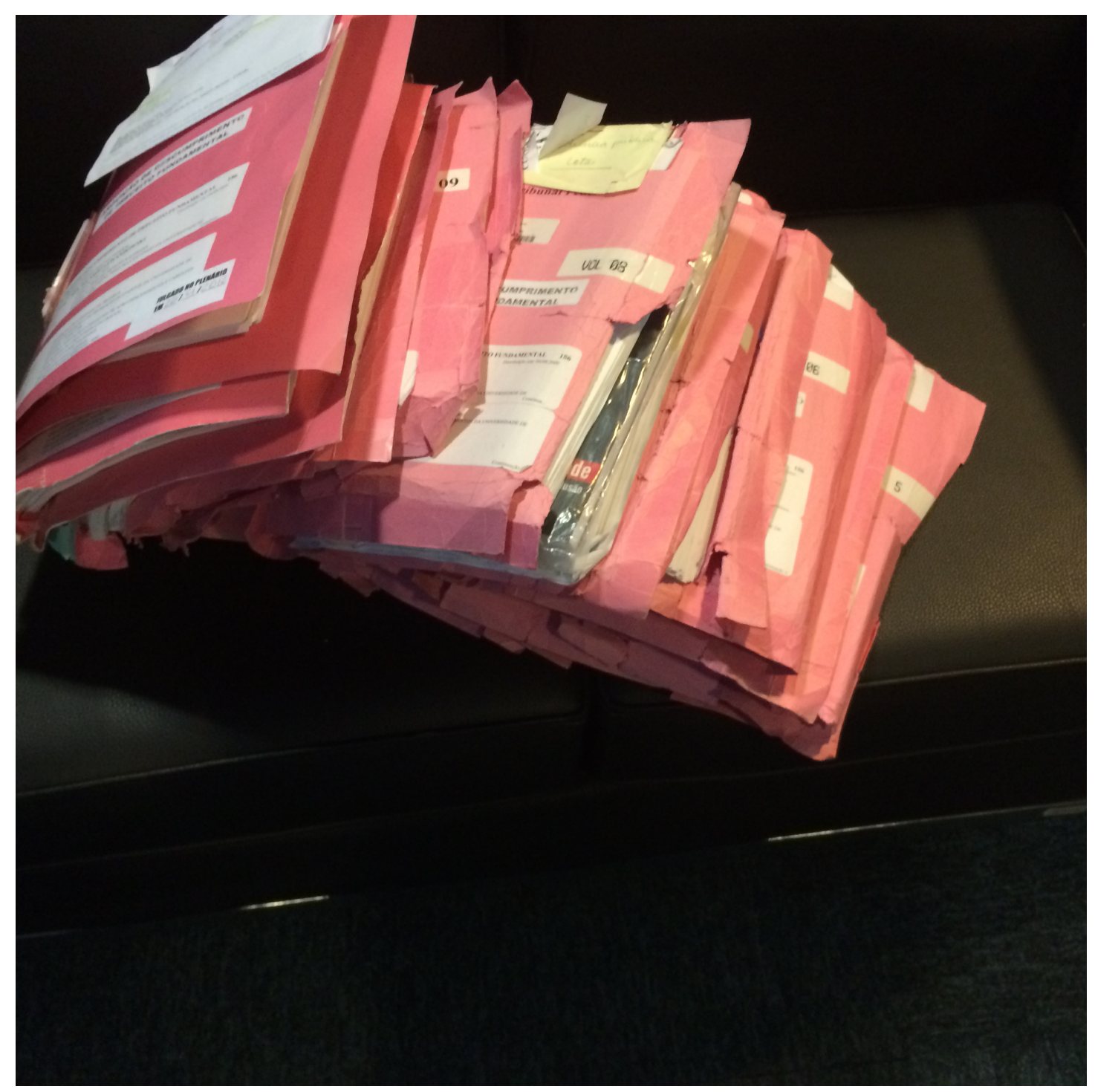

Figura 6 - Autos processuais concluídos. 


\title{
CAPÍTULO 3 - O DIREITO COMO TÉCNICA E A TÉCNICA DO DIREITO
}

\author{
Eu: O direito é uma técnica?
}

Luís Roberto Barroso: O direito é uma ciência em alguns sentidos. $\mathrm{O}$ direito é uma arte em outros sentidos, e é uma técnica certamente. Ele é uma ciência no sentido de ser um conjunto organizado de conhecimentos, com princípios próprios, gramática própria. Com a ressalva de que o direito é uma ciência normativa que lida com um objeto que é a lei, um fenômeno humano. O jurista não lida com fenômenos que se ordenem independentemente de sua vontade. Ele é também uma técnica no sentido de que é preciso saber como se prepara um recurso, o prazo, onde dar entrada. Sendo assim, é um ofício que exige um certo grau de expertise. É preciso saber como construir uma tese jurídica. Se você usar o argumento de uma forma grosseira, imprecisa, vai produzir resultados distintos do que se espera.

O termo "técnico" aparece nas entrevistas realizadas e nas observações de campo com significados bastante distintos. No capítulo anterior, a noção de técnica aparecia, sobretudo, na fala dos funcionários dos gabinetes e da secretaria judiciária como qualificador de funções de rotina, em oposição àquelas de maior autonomia ou criatividade, em tese reservadas aos ministros e seus funcionários de confiança. $\mathrm{O}$ técnico, aqui, diz respeito a uma restrição, um funcionário da secretaria, assim como grande parte dos funcionários dos gabinetes não está autorizada a discutir as leis através das qualificações. As operações do direito e as normativas estão nesses casos mais ou menos estabilizados.

Poderíamos falar, a partir de Wagner (2012), que o trabalho técnico dos funcionários do Tribunal que produzem e fazem circular os processos pertenceria ao universo da 
convecção. É preciso lembrar que a noção de convecção, de acordo com Wagner, está dialeticamente relacionada à noção de invenção. Em suas palavras: "invenção e convecção mantêm uma relação ao mesmo tempo de interdependência e contradição" (p.96) A contradição é evidenciada em um movimento próprio dessa dialética: ao mesmo tempo em que a convecção depende da capacidade inventiva, ela tende a ocultá-la:

\begin{abstract}
A invenção muda as coisas, e a convecção decompõe essa mudança num mundo reconhecível. [...] As invenções nas quais ele se realiza só se tornam possíveis mediante o fenômeno do controle e o mascaramento que o acompanha. (p.98)
\end{abstract}

Nesse sentido, quando se fala em técnico, que, como se verá, aparece de modo similar nas decisões monocráticas dos ministros, tudo se passa como se a atuação fosse quase natural: "estamos aplicando a lei", "seguindo a lei", uma lei que aparece como dada e autoevidente.

O que pretendo explorar neste capítulo são as técnicas relacionadas diretamente à forma de tomada de decisão ou de elaboração dos votos. Embora em alguns momentos se adote a noção de técnica enquanto categoria nativa, o atravessa o capítulo consiste na tentativa de compreender o caráter técnico do direito em uma dimensão que envolve as ideologias legais, os instrumentos jurídicos, os atores profissionais e estudiosos - os paradigmas de resolução de conflitos, a orientação para a definição concreta dos processos, além de uma forma de raciocínio e argumentação (Riles, 2005)

No capítulo anterior, ao seguir a criação de um processo, busquei demonstrar que os caminhos técnicos burocráticos pelos quais uma demanda judicial é transformada em autos processuais constituem uma prática de conhecimento que coloca em movimento diversos elementos, sem os quais não é possível que o direito seja operado. A validade do discurso jurídico está inscrita também na lógica dos procedimentos. 
Neste momento, as ferramentas apresentadas são menos materiais, mas não deixam de ser ferramentas. O processo estará nas mãos dos ministros - o que não quer dizer que esteja apenas na sala do juiz e que ele tomará sozinho uma decisão; o foco agora são as condições de possibilidade das decisões, as técnicas de "ligações", nos termos de Latour (2010), quando uma ponte deverá ser construída entre os diversos textos produzidos nos processos e o texto constitucional.

A alquimia de uma decisão é um processo mais ou menos complexo que envolve diversos dispositivos, uma constelação de teorias, ponderações e consequências, tendo em vista que sempre existe mais de uma resposta possível. Nesse sentido, segundo Riles (2005), as técnicas legais não devem ser entendidas simplesmente como dispositivos que legitimam interesses políticos. A dimensão técnica do direito é precisamente o que o diferencia da política ou da filosofia, da arte ou da literatura, não sendo possível compreender seus modos de operação sem ela. Não se trata de dizer que o direito é apenas técnica, o que certamente seria um equívoco, até porque a técnica guarda sua política própria. O direito operado no STF não é só técnica, mas sem a técnica, como argumenta Riles, não existe direito.

No relatório anual de 2013, publicado pela presidência do Tribunal, mais de 90.000 decisões foram tomadas no STF nesse ano, entre decisões interlocutórias, liminares, de repercussão geral e decisão final. Desse montante, 75.905 foram decisões tomadas monocraticamente. Em regra, uma decisão monocrática é entendida como sendo aquela tomada por apenas um dos 11 ministros do Tribunal, entretanto não é exatamente desse modo que esse tipo de decisão funciona.

Todas as vezes que perguntei a algum funcionário ou aos ministros que entrevistei sobre as decisões monocráticas, elas eram qualificadas como decisões técnicas. A razão dessa qualificação estaria na forma como ela deve ser tomada. As decisões monocráticas são autorizadas pelo regimento do STF e pela legislação, para alguns tipos de processo como habeas corpus, por exemplo, em que existe jurisprudência pacificada do Tribunal sobre a matéria em questão. Resta aos ministros "aplicar" a jurisprudência. Desse modo, existiria aqui também uma estabilidade. Se uma ação é identificada como tendo o mesmo objeto de outras sobre as quais já existem decisões pacificadas do Tribunal, mudam-se os nomes e aplica-se o modelo. 
A jurisprudência pacificada ou dominante seria o conjunto de decisões em casos semelhantes com o mesmo resultado. A repetição desse resultado nos diversos casos é que qualifica o dispositivo decisório como pacificado, ou seja, depois de se discutir nos processos qual seria a resposta mais adequada, essa resposta deve ser replicada, e não rediscutida. Um ministro deve então, ainda que o seu entendimento seja divergente, acatar a decisão do Tribunal. O caráter técnico desse tipo de decisão parece caracterizar uma não atuação.

No entanto, a ideia de dominante ou pacificada parece estar sempre na iminência de uma transformação; a qualquer momento o que era pacífico pode deixar de ser, até porque a ideia de pacificada está diretamente relacionada ao potencial dos processos e a cor das pastas em que eles se enquadram. Qualquer sinal de que um processo sobre o qual se deveria aplicar a jurisprudência pacificada levanta uma questão reconhecida como "importante" ou "delicada" pode levá-lo ao plenário, ou à turma, permitindo a sua despacificação.

Os processos, no STF, não apenas resolvem disputas jurídicas, mas são também o impulso da transformação do próprio direito que ali é operado. Nesse sentido, o papel dos processos no STF é também o de forçar uma mudança de paradigmas. Como se tentassem dizer ao Tribunal que o caso apresenta questões novas, nunca discutidas nos termos dos advogados "um novo ângulo" -, não porque os fatos são diferentes, mas, sobretudo, porque demonstram o "esgotamento dos recursos conceituais do paradigma corrente" (Riles, 2004). Esse seria o impulso da mudança, a ser abordado mais adiante.

Grande parte dos recursos julgados pelo tribunal também é considerada técnica, no sentido de que sua resolução não precisaria de nada além da própria técnica jurídica, a mais básica delas, o silogismo. Esse tipo de processo normalmente é julgado pelas duas turmas do Tribunal, em sessões nas quais poucas vezes ocorrem grandes debates. Não seria a Turma o local apropriado para se rediscutir alguma "matéria de fundo". O comum é que o relator leia seu voto inteiro, ou apenas a parte dispositiva do seu voto, e que seja acompanhado pelos colegas da Turma. Ainda que exista divergência, os ministros já sabem antecipadamente a posição do colega; desse modo, apenas declaram o voto vencido. Quando se diz que já sabem, não se quer dizer que foram 
avisados antes da sessão, mas que grande parte dos processos julgados na Turma é semelhante quanto ao objeto jurídico, e as posições já estão firmadas (não podemos dizer com precisão a porcentagem de cada tipo de processo, mas acompanhamos mais de 20 sessões das turmas do STF, e em sua imensa maioria, eram julgados habeas corpus). Se em um desses processos existir alguma questão "delicada" ou "relevante", o recurso pode ser levado ao plenário, ou ainda a Turma pode decidi-lo mesmo que os ministros destaquem que ali existe uma dessas questões, que ela só deverá ser decidida no futuro, ou seja, a partir de outro processo.

Nos julgamentos de recursos como habeas corpus, por exemplo, o trabalho do Tribunal consiste em garantir a adequação das premissas por ele mesmo instauradas, bem como a legalidade dos procedimentos que envolvem o devido processo legal. Se garantidos esses dois registros, ou seja, o uso preciso dos instrumentos, as decisões estarão sempre juridicamente corretas. $\mathrm{O}$ funcionamento do silogismo dedutivo não envolve premissas preexistentes; não é o texto legal a premissa maior, mas uma interpretação dele, e uma vez que essa premissa é instaurada, a conclusão seria inevitável. Assim, qualquer resultado diferente do esperado gera recursos que serão julgados pelo STF. Por exemplo: no caso do Habeas Corpus 121.903, tratava-se de um homem respondendo a processo penal, por ter supostamente furtado um galo e uma galinha, no valor estimado de $\mathrm{R} \$ 40,00$. A primeira turma do STF decidiu, por maioria, que tinha razão o defensor quando reclamava a aplicação do princípio da insignificância no caso e determinou o trancamento da ação penal. Ladrão de galinhas aparece aqui como um caso concreto, mas é também uma expressão para referir as categorias de processos que não deveriam chegar ao STF.

A jurisprudência pacífica do STF aplica o princípio a casos como esses, em que o valor da prática ilícita é inexpressivo, somado ao reduzido grau de reprovabilidade da ação. No entanto, o princípio da insignificância não está previsto no código penal; é uma criação da jurisprudência, replicada pelos ministros do STF. Logo, se o STF aplica o princípio a casos que se enquadrem nas balizas instauradas, as instâncias inferiores deverão também aplicá-lo.

Esse é um típico caso que os funcionários do Tribunal consideram que não deveria chegar ao STF. O motivo central seria que casos individuais "irrelevantes" atrapalham 
os trabalhos da corte. No entanto, parece-me também que a crítica é endereçada aos próprios juízes de instâncias inferiores. Não foi difícil para os ministros resolverem o caso, pois as premissas já estavam instauradas e o resultado não deveria ser outro que não o trancamento da ação penal. Todavia, se imaginarmos que ninguém mais pode recorrer de decisões "pacificadas" ou que todos os juízes devem decidir da mesma forma, teríamos menos processos circulando, ou talvez precisássemos de menos juízes, mas sobretudo qualquer possibilidade de mudança seriam mais restritas.

O próprio princípio "pacífico" da insignificância destacado no caso do suposto ladrão de galinhas, vem sofrendo inflexões nos últimos anos: nem todos os ladrões de galinha têm suas ações penais trancadas. Caso tenha roubado galinhas mais de uma vez - mesmo que não exista condenação formal, ou tenha "ultrapassado obstáculos" para o roubo, o princípio não será aplicado.

O que pretendo demonstrar neste capítulo é que as passagens - do texto legislativo à interpretação abstrata- ao caso concreto - não são tão simples quanto parecem. A operação de "aplicar a Constituição" envolve critérios hermenêuticos específicos. O papel principal dos ministros do STF, conforme dizem, é garantir uma interpretação tecnicamente correta da legislação e, sobretudo, das normas constitucionais. Embora não exista um monopólio do STF na interpretação dos comandos constitucionais (pelo menos em tese), os ministros do Tribunal são provocados a se pronunciar em caso de controvérsias sobre os sentidos e a extensão das normas. Alguns dos ministros costumam dizer que o tribunal é responsável por dar a "última palavra" sobre os sentidos dos textos legais. De fato, nos casos concretos em que se pronunciam pode operar a ideia da última palavra, mas de modo geral essa "última palavra" não existe, porque as coisas e as palavras sempre mudam.

A primeira tentativa de compreender o que se passava quando os ministros diziam que interpretavam a lei e a Constituição foi a de entrevistar os próprios ministros. Contudo, as entrevistas poucas vezes deixavam claro, pelo menos para mim, sem formação jurídica, quais eram os movimentos desse processo. Nesse sentido, as entrevistas realizadas com os ministros do Tribunal serviram como um norte, mas não esclareceram quais os critérios, se é que eles existem, ou como se definem os métodos e as técnicas que serão utilizadas. Ter como foco apenas as entrevistas poderia levar a 
um entendimento precipitado em relação ao convencimento dos juízes, especialmente quando alguns deles afirmam que decidem um processo antes de buscar a resposta nos textos normativos. Quando ouvia coisas desse tipo imaginava a princípio que as decisões eram sempre arbitrárias e que os ministros viravam as costas para o processo. No entanto, ao longo do trabalho de campo percebi que não era esse o sentido do que me falavam, até porque os mesmos juízes que diziam que sua forma de decisão era dessa maneira em outros momentos declaravam exatamente o contrário.

Ao discutir as técnicas de produção jurídica, Riles (2010) observa que os instrumentos técnicos do direito são entendidos pelos operadores (a autora se refere tanto aos advogados que trabalham com direito econômico no Japão quanto aos juristas norteamericanos) como meios para determinados fins. A autora assenta que a prática do direito, como forma de realizar o conhecimento jurídico, consiste exatamente em um conjunto de relações de meios e fins. Ao entender o direito como um tipo de tecnologia, Riles, na esteira do argumento de Heidegger, distancia-se de uma definição puramente instrumental - um meio para um fim -, para afirmar que:

a essência da tecnologia são seus meios, mais bem entendidos como forma de revelar. A técnica como prática de conhecimento revela $\mathrm{o}$ que não é um fim em si mesmo, mas que, no entanto, coloca em primeiro plano seus próprios meios (Heidegger apud Riles, 2004, p. 789).

No STF, não raras vezes podemos ouvir dos ministros ou dos funcionários do Tribunal que seus compromissos são com a garantia do Estado Democrático de Direto, com a realização da justiça e, sobretudo, com a Constituição. Contudo, esses compromissos são sempre mediados, seja pelos processos, seja pelos limites da legislação, ou ainda pela ideia da "boa aplicação do direito". Existe assim uma matemática da decisão que visualiza os fins preservando ao máximo seus meios, ao ponto em meios e fins podem se tornar a mesma coisa. 
Se um processo levanta uma questão relevante que poderia corrigir uma suposta injustiça, mas que não cumpre os “critérios estéticos" relevantes, ele não será "conhecido", o que significa que os ministros não irão decidir o mérito do caso. Caso alguém apresente uma ação questionando a constitucionalidade de uma lei, mas não esteja entre os legitimados para à propositura, ainda que a lei seja de fato inconstitucional, ela continuará válida até que outro processo questione sua validade.

O compromisso com a análise dos meios e fins não se dá apenas nos casos não julgados, quando se potencializam os meios - instrumentos -, mas serve de parâmetro na análise de mérito dos processos e compõe as técnicas de decisão de diferentes formas que serão expostas ao longo do capítulo. Desse modo, ainda que se possa dizer que em determinada decisão verifica-se a posição política pessoal de um ministro, existem outros critérios técnicos que devem ser operados.

Quando entrevistei o ministro Marco Aurélio, ele expôs a forma como toma uma decisão:

$\mathrm{Eu}$ atuo sem ideias preconcebidas. Depois de ler um processo eu vislumbro a solução mais justa, para depois buscar o apoio no arcabouço normativo. Se não há, eu tenho que retroagir e seguir ordem jurídica. $^{26}$

Como dar sentido a essa forma de decisão, levando a sério o que disse o ministro: "Eu atuo sem ideias preconcebidas", parece indicar um distanciamento de suas concepções pessoais sobre um processo. Ao mesmo tempo o ministro declarou que vislumbra a solução mais justa antes que buscar apoio no arcabouço normativo. O que parece relevante aqui é o "depois que leio um processo"; a solução mais justa então é extraída do processo, e não de fora dele. Todavia o que é mais justo nem sempre

\footnotetext{
${ }^{26}$ Entrevista realizada em 13/06/2012
} 
segue a ordem jurídica; direito e justiça não são a mesma coisa. A ideia de justiça é um fim a ser equacionado na interpretação. Qualquer conclusão definitiva sobre a tomada de decisão apenas tentando dar sentido ao que dizem os ministros sobre esse processo em entrevistas não me pareceu o caminho mais produtivo. Não é possível saber o que se passa na cabeça de um juiz.

A segunda alternativa que nos pareceu mais produtiva foi a de voltar aos julgamentos depois de entrevistar os ministros. No capítulo final será descrito com mais precisão o ritual de um julgamento no STF, mas já adianto que a dinâmica da sessão tem efeitos nas decisões que serão proferidas. Por ora apresento alguns trechos de julgamentos apenas para demonstrar critérios, e as passagens que marcam as interpretações realizadas pelos ministros. Associo-me aqui ao método proposto por Latour (2010) quando recomendou aos etnógrafos que, não sendo possível acessar os processos mentais que envolvem uma decisão, seria necessário substituí-lo por aquilo que parece importar na atividade dos ministros. Comparando o direito com a ciência, Latour afirma que os objetos importantes para os conselheiros do Tribunal não são tão óbvios quanto os objetos dos laboratórios científicos. Na ciência, argumenta o autor, os objetos relevantes são claramente visíveis, e os textos, muito menos; no caso do direito, os textos são onipresentes, enquanto os objetos são invisíveis. Para compreender a passagem da lei, Latour identifica nos julgamentos o transporte e a circulação de "objetos de valor" 27 , que se tornam os condicionantes para que uma decisão possa ser declarada. Diz o autor:

${ }^{27}$ Os objetos de valor identificados por Latour no Conselho de Estado Francês são: a autoridade dos membros de conselho, o progresso dos argumentos do caso, o fluxo dos autos processuais que deve ser rigorosamente gerenciado, as modificações dos interesses dos casos e o peso da jurisprudência. 
Embora o raciocínio mental seja inacessível a um observador equipado apenas com um caderno, as sentenças proferidas pelos membros do Conselho, no entanto, apresentam sinais explícitos de mudanças que fazem em relação aos processos com que estão lidando, e cada um desses sinais indica a transição, o movimento ou a metamorfose de uma força especial cuja dinâmica estamos a reconstituir. [...] Vamos tentar entender o que os conselheiros fazem passar através de sua interação e que lhes permite avaliar a qualidade da sua ação ( p.143)

Faço aqui uma combinação entre as propostas de Riles e Latour, para, a partir das declarações, reconstituir tanto os objetos de valor como a técnica que parece operar as decisões e que se torna visível em alguns dos julgamentos. Em certa medida, a própria técnica é um objeto de valor transportado na decisão. Convém destacar que a própria ideia de controle de constitucionalidade é a de um conjunto de técnicas que testam a legislação ou os atos de poder público a partir de uma "multitude de detalhes". Essas leis ou atos, quando chegam ao STF, tornam-se objeto de análises formais e materiais - de conteúdo -, a partir de um gabarito que não é um todo coerente, mas que também não permite que qualquer coisa seja feita. Como argumentou Latour (2010), existe um conjunto sutil de transformações operadas nos julgamentos e lhe parece evidente que o que está envolvido não é exatamente um processo de raciocínio em que exista um fluxo de ideias homogêneas que estariam ligadas entre si mais ou menos logicamente. E tampouco, acrescenta o autor, existe um corpo ordenado de textos legais que seriam suficientes para unir as coisas a fim de gerar outro documento. A "passagem da lei” manifesta-se primeiro na modificação que sofrem os objetos de valor no curso da ordenação, através da qual sua circulação é acelerada ou reduzida (p. 140).

O critério dos casos escolhidos é aquele em que as decisões pareciam ser tomadas em plenário, a partir do debate entre os ministros. Quando apenas leem os votos, torna-se mais difícil perceber o que está operando no caso, já que existe uma diferença entre os critérios que fazem decisões e a argumentação usada pelos ministros. 
Durante uma palestra do ministro aposentado do STF, Eros Grau, este afirmou "que interpretar é transformar uma coisa em outra”. De fato, o ato de interpretação não parece ser nada, além disto: um ato de transformação. O texto legal, ao ser interpretado, transforma-se em outra coisa. No entanto, existe um esforço da decisão que, ao contrário de demonstrar uma transformação, tende a minimizá-la.

Existem alguns métodos e técnicas disponíveis aos juízes (gramatical, teleológico, histórico, sistemático, tópico), entretanto, não me parece que expor as formas de cada um desses métodos e técnicas ajude a compreender o que se passa durante a produção de uma decisão, até mesmo porque nenhum desses métodos opera de modo exclusivo. Também parece importante ressaltar que o verbo que é empregado na interpretação constitucional é o revelar; as interpretações do Tribunal, ou dos ministros, revelam os sentidos do texto normativo. Vamos então aos casos.

O primeiro caso apresentado é um recurso que pretendia reverter uma decisão de tribunal de primeiro grau e assegurar imunidade tributária aos hospitais de economia mista (públicos e privados). Os hospitais teriam sido expropriados na década de $70 \mathrm{e}$ passaram a ser controlado pela União, que detém 99,9\% do quadro acionário. Destaco desde já que a questão era aparentemente fácil - ou pelo menos assim foi considerada pelos funcionários com quem conversei. Pessoa jurídica de direito privado (empresa) deve pagar impostos estaduais, logo seria claramente constitucional cobrá-los. Somese a isso o fato de que a própria União participou do processo defendendo essa interpretação.

Relator: Por esses motivos que apresentei, eu nego provimento ao recurso $(\mathrm{O}$ relator concluiu que os hospitais deveriam pagar os impostos.)

Ministro A: Eu estava aqui perplexo, pois o controlador quer pagar imposto e o controlado não quer. Essas questões deveriam ser decididas em âmbito administrativo, mas estamos aqui. Apesar de a Constituição estabelecer que a saúde é direito de todos e dever do 
Estado, sendo uma função de dever público, e que a atividade privada é complementar, é fato que a Constituição também estabeleceu que a assistência à saúde é livre à iniciativa privada. E por mais paradoxo que possa parecer, existe um mercado da saúde. Da conjugação do que está no artigo 150, 6a, que na sua literalidade estabelece apenas a fundação e a autarquia [como detentoras de imunidade tributária] e mesmo com o acréscimo da jurisprudência desse Tribunal, que acrescentou às empresas públicas e às sociedades de economia mista. Quais? As que são prestadoras de serviços públicos exclusivos do Estado. A saúde, por mais pública que seja, no nosso texto constitucional não está estabelecida como exclusiva. E eu vou também ao artigo 173 da Constituição, que diz... (Lê o artigo.)

Ministro B: [...] Quero fazer uma observação só para que se veja o tamanho da balbúrdia que se criou. [...] Cuida-se de empresa que foi objeto de expropriação em razão da continuidade mesmo da prestação dos serviços de saúde, mas em relação, por exemplo, aos Correios, empresa pública que exerce atividade de serviço público e tem uma atividade monopolística, nós temos reconhecido a imunidade [precedente RE 601.392]. Eu tenho dificuldade de fazer uma sacralização da forma, tendo em vista inclusive as situações peculiares que nós vivenciamos no âmbito do direito administrativo constitucional. Temos essas entidades que exercem atividades típicas do Estado, mas são consideradas privadas. O difícil é fazer uma caracterização na natureza jurídica dessas entidades.

Ministro C: Há um outro dado que me chama atenção. Porque na verdade a pergunta é a seguinte: se ao invés de 99,9\%, se todo capital fosse da União, o hospital seria um hospital público. Só porque $0,01 \%$ não é, muda o regime jurídico?

Ministro A: Essa é uma boa pergunta. 
Ministro D: Mas aí não é público.

Ministro C: O problema é que eles querem manter a aparência de uma sociedade anônima quando, na verdade, 99,9\% do capital é da União.

Ministro A: Por que a União não incorporou todas as ações? A rigor temos que fazer a análise do serviço que se presta, e infelizmente aqui há uma mescla de institucionalidade e realidade. Nós temos que analisar se esta entidade presta serviço público.

Ministro E: Estou examinando nos autos que o hospital não está limitado à prestação de serviço público. Não há garantia que esse controle acionário seja passado, com a imunidade [tributária] junto.

Ministro C: Isso seria uma desestatização.

Ministro A: Isso é outra coisa, isso é privatização.

Ministro C: Nesse caso não, porque se trata de uma atividade pública.

Ministro E: Podemos fazer uma decisão condicional. Eu nunca vi uma sentença condicional, mas tudo bem.

Ministro F: Quanto à questão do ser ou não ser, que apareceu nesse caso, eu acompanho o relator, negando provimento.

Ministro C: Aqui, na verdade, estamos diante de uma ficção. Entendeu-se que era conveniente manter como sociedade de economia mista.

Ministro F: O que a União fez, me permitam o prosaísmo, foi um salto triplo carpado. 
Ministro C: O que nos vem do artigo 173 (lê o artigo), e isso remete diretamente à cabeça do artigo, que está em bom português, é que o fato de a União deter $99,9 \%$ não transforma a sociedade anônima em pessoa jurídica de direito público. Nego o recurso.

Ministro B: Se pudéssemos abstrair o $0,01 \%$, teríamos um hospital público da União, e como tal evidentemente estaria abrangido pela imunidade, e por isso mesmo não pode ser tributado. Segundo consta na petição inicial, que faz referência a um documento, documento número 11, e não foi contestado. Dizem o seguinte as impetrantes: que desde 31 de dezembro de 2003 atende exclusivamente pelo SUS. É o Estado prestando serviço de saúde por uma entidade que é do Estado.

Relator: Em princípio eu acompanho argumentação do recorrente, mas no caso estou negando provimento em razão do insólito da situação: o fato de o próprio controlador, a União, ter vindo aos autos e dizer que discorda da concessão da imunidade.

Ministro C: Isso é espantoso. A União está querendo perder dinheiro.

Ministro B: Eu vou pedir vista.

Ministro A: É, acho importante.

Algum tempo depois o colegiado voltou a examinar o caso e deu provimento ao recurso, o que significa que os hospitais garantiram a imunidade tributária. Todavia o resultado não será relevante, tendo em vista que o que pretendo estabelecer são aspectos que produzem decisões. A primeira questão que chama atenção é que as possíveis combinações de artigos constitucionais podem produzir resultados distintos. No caso descrito, cada uma das combinações revelou, nos termos locais, entendimentos divergentes, no entanto, em última instância o que parece interessante 
é que os próprios objetos eram diferentes: por um lado, a possibilidade de se tratar de uma empresa pública, por outro, de uma empresa de economia mista.

Existem duas condicionantes que parecem operar nesse julgamento. Se, por um lado, se pode abstrair o $0,01 \%$ para dizer que se trata de uma empresa pública, logo, apesar do $0,01 \%$, quem controla os hospitais é o Estado. Por outro lado, pode-se também abstrair que se trata apenas de $0,01 \%$, logo, mesmo que sejam porcentagens pequenas, ainda assim seria uma empresa de economia mista. Essas duas operações enquadrariam os hospitais em regras previstas em artigos constitucionais diferentes, sobre os quais bastaria uma interpretação literal; isso quer dizer: apenas a leitura do texto, que está em "bom português", é suficiente para se verificar se foram cumpridos os requisitos que permitem ou não a isenção fiscal.

O problema central nesse caso não está na interpretação da lei, ou pelo menos não a princípio, mas na interpretação sobre qual artigo constitucional deve ser acionado no caso. O passo seguinte não é mais simples, porque mesmo que se considerem os hospitais apenas como empresas de economia mista, a jurisprudência do STF estabeleceu que essas empresas quando prestam serviços públicos exclusivos do Estado (como os Correios) estão abrigadas na imunidade tributária. Entretanto, os serviços da saúde embora públicos não são, a princípio, exclusivos, e para garantir a imunidade o Tribunal deverá flexionar a exclusividade. A dúvida é enunciada pela expressão "tenho dificuldade", que aparece em grande parte dos julgamentos, e aqui está relacionada ao serviço que prestam os hospitais. Se o serviço prestado concorre com as empresas privadas, conceder imunidade tributária seria inconstitucional. Os ministros não pareciam ter certeza acerca do tipo de atividade que prestam os hospitais, mas aqui um único documento resolveu o caso, o documento número 11, que consta nos autos processuais. $\mathrm{O}$ documento afirmava que os hospitais prestam serviço exclusivamente pelo SUS e como não foi "contestado" presume-se que seu conteúdo seja verdadeiro.

Outro elemento que dificulta a resolução do caso é a posição defendida pela União nos autos, que aos ministros pareceu contraditória. As decisões do Tribunal precisam levar em conta os argumentos presentes nos autos. Na realidade, os argumentos são extraídos dos documentos entregues pelas partes e submetidos aos critérios dos 
ministros. De certa forma, não existe nada na argumentação dos ministros que já não esteja nos autos. No entanto, os argumentos extraídos, que figuram nos relatórios dos funcionários e nos documentos dos autos são resinificados, vão sendo, ao longo do julgamento e a partir dos parâmetros jurisprudenciais e doutrinários, contextualizados, estendidos ou limitados, desconectados dos interesses das partes, ainda que no final das contas os ministros apenas concordem com o que foi apresentado nas petições. Os argumentos não "merecem prosperar", vão sendo descartados ao longo dos julgamentos.

$\mathrm{O}$ entendimento firmado pelos ministros foi o de que empresas que prestam exclusivamente serviços públicos, ainda que esses não sejam exclusivos, estão abrigadas pela imunidade tributária. A atuação dessas empresas corresponderia à própria atuação do Estado, e aqui o entendimento é estendido a outros casos semelhantes que não apenas os hospitais, porque a decisão precisa ser generalizada.

O "como se" é uma forma acionada em vários casos, permitindo outra operação básica da técnica jurídica que é analogia. "Ver uma coisa como se fosse outra" (Wagner 1996, p. 9) tida como semelhante ou conexa inscreve o processo em uma rede de referências que é dada pela jurisprudência. Qualquer caso decidido pelo Tribunal deve levar em conta sua jurisprudência; é ela a garantia de que não se está “inventando demais", expressão usada por alguns ministros e funcionários do Tribunal que quer dizer que ministros algumas vezes "não resistem a agir como legisladores", assegurando também que as coisas, embora estejam sempre sendo transformadas, não mudem ao ponto de fugir a regras de previsibilidade e segurança. Desse modo, a posição dos ministros precisa ser localizável e reconhecível ou nos precedentes ou na doutrina, e de preferência, nos dois registros.

A pesquisa da jurisprudência e os precedentes que serão usados na decisão possibilitam que um entendimento seja revelado. Os precedentes fornecem aos ministros um mapa de possibilidades e permitem a comparação e a analogia. Um novo processo só pode ser solucionado a partir dessa comparação com outros casos que "foram reunidos sob uma mesma regra ou princípio" (Riles 2007), ou ainda, com 
a mesma indexação ${ }^{28}$. Tendo em vista que os sentidos das normas constitucionais ou legais, vão sendo aos poucos definidos e criados pela jurisprudência, portanto, sua observância é elemento fundamental de uma nova decisão. Como destacou Bevilacqua (2011), a jurisprudência gradativamente consolidada contribui de forma ativa para criar ou reconfigurar o próprio mundo ao qual suas disposições se referem (p. 67). A analogia pode operar então a partir da comparação, combinação ou justaposição dos diversos documentos e textos produzidos nos autos processuais e de outras camadas de textos que são os parâmetros jurisprudenciais e normativos.

No entanto, existe uma peculiaridade no uso dos precedentes nos votos. Não necessariamente existe uma continuidade lógica entre o que se está decidindo e a racionalidade que operou no precedente citado, até porque, como já foi dito no capítulo anterior, o encontro dos precedentes depende dos critérios de busca utilizados pelos funcionários dos gabinetes. Algumas vezes os ministros apenas anexam numericamente o precedente ao voto ou citam pequenos trechos dos votos individuais proferidos no caso anterior. Esse mesmo precedente será anexado ao dispositivo decisório, sem que seja preciso expor a ratio decidendi, que torna o precedente compatível, ou que exista a necessidade de uma análise mais aprofundada da jurisprudência sobre determinada matéria. Como já observaram Soares e Melo e Souza (2013)

a prática de utilizar argumentos retirados de julgados anteriores, sem um exame mais detalhado do contexto e das discussões que cercam a decisão, caminha na direção contrária a toda uniformização. Neste sentido, os julgados são usados, por assim dizer, como um repositório de possibilidades à disposição do julgador, onde os argumentos são descontextualizados e resinificados em contextos

\footnotetext{
${ }^{28}$ A indexação de um acórdão é diferente da indexação dos autos e é feita na Seção de Composição de Acórdãos. Essa indexação consta no próprio documento da decisão.
} 
novos cujo resultado é, talvez, incompatível com o sentido original. (p75)

O que me parece operar no uso dos precedentes é a justaposição definida por Yngvesson e Coutin (2008). Conforme as autoras, a justaposição implica buscar correspondências entre os fragmentos que podem ser contrários. Estas correspondências são possíveis não por uma forma que existe fora do âmbito dos fenômenos, mas sim pela possibilidade da própria analogia. Os precedentes compatíveis, ou supostamente compatíveis transportariam ao novo caso a autoridade de seu dispositivo, ainda que existam diferenças fundamentais entre o que se está a decidir e o que já foi decidido. O contexto de uma decisão tomada como precedente é menos importante do que a ideia de continuidade - real ou operacional- que ela agrega à nova decisão, o efeito aqui é quase formal.

Ainda que apareçam como suporte de uma nova decisão, os precedentes passam por uma transformação durante um novo julgamento e a nova decisão "replica" (Biagiolio, 2006) as decisões anteriores, lembrando que a réplica não é sinônimo de reprodução. No caso descrito acima, se o precedente dos Correios tivesse sido apenas reproduzido, o resultado seria outro, dado que serviço público exclusivo e exclusivamente serviço público não têm exatamente o mesmo sentido. O que une os dois casos é que supostamente carregam a mesma hipótese jurídica, sendo tecnicamente iguais. No caso dos Correios, o Estado (União) detém o monopólio do serviço prestado; no caso dos hospitais, estes prestam o serviço de saúde exclusivamente através do Sistema Único de Saúde - fato que retirou do hospital (empresa) a característica de praticar atividade econômica, cumprindo a teleologia implícita da norma, ou seja, seus objetivos.

Esse movimento de tornar explícito ${ }^{29}$ parece movimentar as interpretações jurídicas. O objetivo da técnica está tanto em extrair do texto legal o explícito e o evidente (“de

\footnotetext{
${ }^{29}$ Strathern descreve o movimento de "tornar explícito" como um modo de literalização, de colocar para fora coordenadas pressupostas (1992, p. 5).
} 
claridade solar" - essa é a expressão utilizada pelos ministros), como o implícito e o não expresso. De certa forma, o implícito é sempre uma ficção que opera no universo do "como se". "Como se fosse o Estado" não transforma uma empresa de economia mista numa empresa pública, mas, para os efeitos legais de tributação, elas devem ter o mesmo tratamento.

Apresentamos outro caso, em que fica mais clara a ideia de casos diferentes com a mesma hipótese. O caso é um recurso extraordinário em que a União recorreu contra a decisão que garantiu à empresa Varig indenização por conta do plano econômico Cruzado, que congelou as tarifas das empresas entre 1985 e 1992. Depois do voto de um dos ministros, que dava provimento ao recurso, negando a possibilidade de indenização, a ministra relatora argumentou:

Ministra relatora - Eu queria apenas esclarecer para os que não estavam aqui que quando fiz análise longuíssima desse processo, eu em nenhum momento considerei ato ilícito do poder público. Considerei a responsabilidade por ato lícito do poder público, citando até o grande trabalho do Canotilho que é nesse sentido. [...] No caso específico, é como se tivesse que ser feita uma obra numa determinada localidade que precisa de uma rua, quando - o ministro Barroso sabe disso, todos ali sofrem, e alguém vai ter uma indenização. A rua vai deixar de ser feita? Não, nem deve. [...] Eu só quero chamar atenção, sem contestação do voto de Vossa Excelência, brilhantíssimo, calcado na melhor doutrina. Apenas para acentuar para os que não estavam presentes quais foram os fundamentos da conclusão a que cheguei.

Ministro A - É que a doutrina sobre da responsabilidade civil do Estado é muito clara, no sentido de em situações como essas em que se alega que um ato de natureza legislativa... a doutrina é no sentido de excluir a responsabilidade, e não de afirmá-la. 
No mundo dos fatos uma obra numa rua e um plano econômico não são a mesma coisa, todavia na operação jurídica carregam a mesma hipótese, logo a técnica que envolve sua solução é a mesma. Não importa, portanto, o nível de complexidade da situação concreta, pois uma rua ou um plano econômico não são diferentes do ponto de vista jurídico. O recurso de simplificar o caso é amplamente utilizado pelos ministros, exatamente porque permite extrair a questão de direito sem se perder nos detalhes e complexidades do mundo dos fatos. Identificada a questão jurídica "de fundo", torna-se mais simples também a busca de respostas na doutrina jurídica.

A doutrina é um instrumento utilizado pelos juízes e, como instrumento, ela é manipulada com o objetivo de sustentar uma decisão. Mais precisamente várias delas, tendo em vista que um processo judicial demanda tipos diferentes de decisões. Inicialmente os ministros decidem as questões preliminares, ou seja, se os advogados utilizaram os meios corretos para apresentar a demanda, se existe conformidade entre as causas de pedir e as normas jurídicas relacionadas a ela, para depois decidirem o mérito do caso. Mesmo uma decisão preliminar que reconhece o processo como apto a ser julgado envolve um equacionamento a partir da doutrina e da jurisprudência. Desse modo, cada parte do processo é abarcada pela noção de autoridade contida nos dois registros.

Ainda que nas decisões apareçam citados explicitamente apenas os precedentes, a doutrina está contida no dispositivo decisório. Se abrirmos todos os casos citados como precedentes de uma decisão, será possível encontrar seu suporte doutrinário, contudo, com o tempo e a repetição das questões, esse suporte não precisaria mais estar evidenciado porque a própria jurisprudência já o incorporou.

Em seu trabalho a respeito da produção científica, Latour (1988) buscou demonstrar que os fatos tidos como naturais seriam na realidade uma coleção de declarações que se tornam verdade quando matriculam aliados suficientes. Parece-me que existe na produção decisória do STF um movimento análogo: uma decisão se torna mais "substanciosa" ou "judiciosa" nos termos locais quando consegue conectar cada vez mais “aliados" jurisprudenciais e doutrinários. 
De modo geral, assim como a jurisprudência, a doutrina transporta a autoridade à decisão, ou seja, compõe a cadeia de autoridades dos processos judiciais. Ainda que durante o transporte, a autoridade dos precedentes e da jurisprudência seja também constituída. No sentido de que, um precedente carrega mais autoridade na medida em que é repetido, assim como doutrinadores ganham maior autoridade na medida em que são citados. Na realidade, a autoridade é acumulada e constituída durante todo o processamento de uma ação. Está nos carimbos dos documentos, na reputação dos advogados, no uso da doutrina e da jurisprudência, e todo esse acúmulo será transportado para a decisão.

Embora a autoridade esteja mais na forma do que no conteúdo, tanto a doutrina como a jurisprudência são instrumentos indispensáveis aos ministros, porquanto não é possível imaginar que um ministro tenha o domínio de todas as áreas do direito, ou que exista uma resposta pronta para todos os processos, desde o ladrão de galinhas até os planos econômicos. O papel da doutrina em uma decisão não está em descrever o mundo (Riles 2001a), mas em ajudar a solucionar problemas. Ainda assim, parece existir a necessidade de se pautar por doutrinadores "consagrados", ou pela "melhor doutrina" porque os juristas assim considerados detêm maior autoridade, sendo fontes mais seguras sobre as quais é possível estabelecer uma decisão.

A questão da autoridade aparece também relacionada ao próprio dispositivo decisório que está sendo constituído durante um julgamento. No primeiro caso apresentado neste capítulo, os ministros demonstraram preocupação com a extensão da decisão que estavam a tomar, já que não tinham certeza sobre o futuro dos serviços prestados pelos hospitais, surgindo inclusive propostas para que formulassem uma decisão condicional. A preocupação com a extensão da decisão, tendo em vista que a parte 
dispositiva de um acórdão é a rigor curta e quase enigmática ${ }^{30}$ porque precisa ser generalizável, aparece também em casos em que os limites da atuação dos ministros não está claro. Embora os juízes sejam obrigados a decidir uma questão que lhes é demandada, não poderiam em tese ultrapassar os limites de um desenho institucional do Estado. No entanto, esses limites nem sempre são claros, e em alguns casos tornam-se objeto de ponderações dos ministros.

Segue trecho do debate envolvendo possíveis ingerências dos ministros do Tribunal no tocante à decisão que declarou constitucional a portaria do Ministério da Justiça que homologou a demarcação da terra indígena Raposa Serra do Sol ${ }^{31}$ :

Ministro relator - Estou negando provimento aos embargos. É como encaminho a votação, presidente. (Após analisar todas as questões

${ }^{30}$ HC 121903 - Ladrão de Galinhas EMENTA: PENAL E PROCESSUAL PENAL. HABEAS CORPUS IMPETRADO CONTRA DECISÃO DE RELATOR DE TRIBUNAL SUPERIOR QUE INDEFERIU PLEITO CAUTELAR EM IDÊNTICA VIA PROCESSUAL. FLAGRANTE LEGALIDADE. SÚMULA 691/STF. SUPERAÇÃO. FURTO (ART. 155, CAPUT , DO CP). PRINCÍPIO DA INSIGNIFICÂNCIA. APLICABILIDADE. HABEAS CORPUS EXTINTO POR INADEQUAÇÃO DA VIA ELEITA. ORDEM CONCEDIDA DE OFÍCIO.

${ }^{31}$ Em 2006 o STF julgou uma ação popular que questionava a validade da portaria do Ministério da Justiça e o decreto presidencial que demarcaram e homologaram a terra indígena Raposa Serra do Sol. No entanto, foram estabelecidas pelo tribunal 19 cláusulas condicionantes para que a terra pudesse ser demarcada, cláusulas essas que foram inseridas na parte dispositiva do acórdão, ou seja, as condicionantes pertencem à decisão. Essa decisão foi objeto de um recurso denominado embargo declaratório, que questionava a competência do Tribunal para estabelecer tais condições. 
apresentadas nos embargos de declaração, o relator confirma a validade da decisão e sua eficácia.)

Ministro A - (...) Ressalto que as condicionantes contidas na parte dispositiva do pronunciamento do Tribunal encerram normas externas e autônomas. O que se pleiteou na inicial desta ação foi, unicamente, a declaração de nulidade da portaria do Ministério da Justiça. (...) Ao invés de julgar simplesmente improcedente o pedido de declaração na ação de nulidade, partiu, o Tribunal, para fixar, e fixar, repito, 19 condicionantes, das mais diversas, que não foram discutidas no processo, de forma abstrata e autônoma. Eu diria que o Executivo nacional inclusive está aguardando o julgamento desses embargos declaratórios até para ter uma diretriz quanto às outras situações conflituosas envolvendo povos indígenas.

Ministro B - Sim, o Relator também ressalta que isto funciona como precedente para efeito de orientação geral, isto está claro. Agora, ele dizia - condizente com a nossa doutrina e a nossa jurisprudência que a decisão não é dotada de efeito vinculante, tanto é que citou precedentes nos quais nós já indeferimos reclamações ${ }^{32}$, mas é uma orientação que emana do Tribunal. De qualquer forma, eu gostaria de lembrar que essas questões todas, por exemplo - hoje a memória já está um tanto quanto prejudicada, em relação às questões que se colocaram, mas, à época, quando essa questão chegou ao Tribunal, se dizia até que tinha de se pedir licença ou tinha de fazer tratado com as tribos indígenas para assentar bases militares. Portanto, essas questões todas foram devidamente contempladas - ou para passar uma estrada, ou realizar uma obra pública. A rigor, não são respostas

\footnotetext{
${ }^{32}$ As Reclamações são processos que correm no STF e demandam que este Tribunal faça cumprir uma decisão do próprio STF e que supostamente não está sendo observada em outras instâncias.
} 
dadas no vazio, mas a partir das situações que se colocaram neste caso e foram extraídas do processo.

Ministro C - Mas eu queria assentar que o Ministro Barroso, em boa hora, afasta essa expressão "condições", dizendo que, na verdade - e leio trecho aqui, páginas 32, o seguinte do voto do Ministro Relator, que diz que não são propriamente condições, mas a maioria dos Ministros, na verdade, explicitou os pressupostos para o reconhecimento da demarcação válida da terra indígena. Então, o que nós fizemos aqui, e eu me recordo bem, apesar do tempo que já se passou desde aquele julgamento, que, a rigor, nós não estabelecemos condições, nós não legislamos em abstrato, mas nós simplesmente assentamos o regime jurídico que deve reger as terras indígenas, pois era necessário, naquele momento, explicitar para pormos fim a um conflito social e fundiário objetivamente posto à Corte.

Ministro B - Eu peço vênia ao eminente Relator e aos que o acompanham para acolher os embargos com efeitos infringentes, tal como fez o Ministro Marco Aurélio, por entender que, realmente, o tribunal extrapolou, traçou parâmetros excessivamente abstratos e completamente alheios ao que foi proposto na ação originariamente. O Tribunal agiu como um verdadeiro legislador. Por essas razões, eu acolho parcialmente os embargos para expungir da decisão as 19 condicionantes que foram acrescentadas.

Relator - A minha constatação é que, se o Tribunal não tem uma atuação um tanto atípica, talvez uma sentença quase aditiva tivesse feito do modo como fez; se tivesse se limitado a julgar a ação improcedente ou procedente em parte, a execução do julgado não teria sido concretizada. Então, eu acho que o Tribunal foi ousado e que esta é uma decisão atípica. Como um padrão, não creio que seja o melhor e, portanto, não acho que o Tribunal deva fazer isso rotineiramente. Mas, neste caso, não se decidiu só a questão pontual, mas se definiu o sistema: nós vamos executar, e o modo de executar 
é esse, está aqui o pacote. Portanto, eu reconheço, na linha do que falaram o Ministro Marco Aurélio e Vossa Excelência, que houve uma atuação um tanto atípica, talvez uma sentença quase aditiva.

Notam-se, a partir de debate, duas questões principais. A primeira delas é a autonomia dos ministros para decidir para além do pedido formulado nos autos, que foi justificada pela afirmação de que as condicionantes foram uma resposta a alguma coisa extraída do processo, que podiam não estar na forma ideal como pedido, mas preencheriam o vazio das condicionantes. A outra preocupação dos ministros diz respeito aos efeitos da decisão. Ainda que possam dizer que a decisão não tem efeito vinculante, não se pode impedir que ela se torne precedente, pois isso iria contra a própria lógica do sistema jurídico. Até porque a própria decisão deverá ser interpretada. O sentido próprio a que ela se refere é dado apenas na hora do

julgamento, não se tendo pleno controle sobre seus efeitos e sua eficácia.

Uma decisão, seguindo Biagiolio (2006) articula dois tempos distintos: a controvérsia concreta a que ela responde e as possíveis decisões futuras nas quais pode ser usada como precedente. Em última instância, o que uma decisão produz é outra decisão, e no caso do STF esse efeito é potencializado tendo em vista que em grande parte dos casos a jurisprudência da corte é tomada como parâmetro para os demais tribunais do país.

\subsection{A VONTADE DA LEI E AS INTENÇÕES DO LEGISLADOR}

Diversas vezes ouvi dos ministros do Supremo que a corte vive um novo momento, que os juízes estão mais "sensíveis" às "questões sociais". De modo geral, a sensibilidade dos ministros se mostra nos casos de maior relevância, que envolvem direitos coletivos e individuas a serem equacionados no processo judicial. A noção de sensibilidade aparece nas entrevistas que realizei com os ministros do STF, como alguma coisa que potencializa o "caráter humanista" da decisão jurídica e exige que 
os ministros lancem mão de outros instrumentos que não apenas a técnica ${ }^{33}$. Nesses casos, os ministros abrem o processo para uma série de inputs externos, como as audiências públicas, em que podem ouvir as diferentes interpretações provenientes de profissionais de outras áreas de conhecimento, políticos e agentes públicos de alguns órgãos do Estado, além de outros advogados que representam diferentes entidades da sociedade civil.

O caso da ADPF 186, citado no capítulo anterior, é um bom exemplo desses processos que exigem mais do que um equacionamento convencional. A questão jurídica apresentada no processo não parecia tecnicamente difícil de ser equacionada. No entanto, esse não é um processo apenas técnico, porque a questão central não é apenas jurídica. O contexto político e cultural não é externo ao direito, é mais um elemento a ser considerado na analítica.

"Tecnicamente" o processo das cotas étnico-raciais poderia ser resolvido por analogia. As referências comparativas citadas pelos ministros estão tanto nos comandos constitucionais como na jurisprudência do Tribunal. Nos votos declarados é possível identificar que o próprio texto constitucional faz referência à reserva de vagas, não em universidade nem à população negra, mas para as pessoas portadoras da deficiência física em concursos públicos. Também está previsto tratamento preferencial a empresas de pequeno porte.

Do mesmo modo, a analogia pode ser operada na jurisprudência da corte. Existe meia dezena de casos tidos como compatíveis. Os citados pelos ministros são duas ADIs. Na primeira delas, o STF declarou a constitucionalidade de lei estadual que prevê isenção fiscal a empresas que contratam percentual de pessoas com mais de 40 anos. A outra consiste num caso em que um homem cego de um dos olhos teve seu direito

${ }^{33}$ Schuch (2008) e Iubel (2006) já destacavam a importância da noção de sensibilidade na operação do Direito como modo de "inserção de novas práticas de promoção e produção da justiça no campo judicial" (2008, p.499). 
de assumir cargo em concurso público em que concorreu nas vagas destinadas a pessoas com deficiência física, tendo garantido seu direito pelo Tribunal.

Tanto os comandos constitucionais como a jurisprudência não se referem a situações iguais, no entanto, quando os ministros conseguem extrair os fundamentos do comando constitucional ou das decisões anteriores do Tribunal, é possível admitir que elas têm uma mesma finalidade: equilibrar situações desiguais quanto ao acesso. As cotas raciais poderiam ser enquadradas nessa hipótese, e não seria difícil aos ministros admitir a constitucionalidade da política. A técnica é utilizada em diversos tipos de processos em que leis e atos do poder público são submetidos ao Tribunal, tendo em vista que não cabe ao STF avaliar se uma lei ou ato é bom ou ruim, mas atestar sua conformidade com a Constituição. Nos processos "sensíveis" a separação entre essas duas avaliações se perde.

O que justifica o pedido central da ADPF 186 não é uma questão imediatamente jurídica. Afirma a inicial que as condições desiguais de acesso à universidade estão baseadas em desigualdades sociais, e não em desigualdades étnico-raciais. Nesse sentido, a abertura do processo permite que outros elementos sejam incorporados, como análises estatísticas, avaliações das políticas de cotas em curso nas universidades públicas etc. Todos esses inputs, que são transformados em documentos e incorporados aos autos e podem compor os votos dos ministros.

Sendo o racismo e a desigualdade étnico-racial constatáveis, a interpretação unânime do Tribunal revelou que a política de cotas não apenas está em conformidade com a Constituição, como também realiza as "intenções" ou a "vontade" emanadas dos princípios constitucionais.

O próximo caso que apresento é também um dos que exigem certa sensibilidade dos ministros. Trata-se de duas ações, uma ADI e uma ADPF, que demandavam do Tribunal uma "interpretação conforme a Constituição" do artigo 1.723 do Código Civil brasileiro, que trata da união estável: 
É reconhecida como entidade familiar a união estável entre o homem e a mulher, configurada na convivência pública, contínua e duradoura e estabelecida com o objetivo de constituição de família.

A técnica demandada objetiva excluir interpretações da lei que impeçam o reconhecimento da união entre pessoas do mesmo sexo no dispositivo. De modo sintético, a técnica de interpretação conforme não declara a lei inconstitucional, nem o poderia; já que a legislação repete a norma constitucional, seria certamente estranho declarar inconstitucional a própria Constituição. Nesse sentido, a técnica apenas limita sua interpretação nos marcos definidos pelo Tribunal. Seguem trechos do debate envolvendo a questão.

Ministro A $-[\ldots]$ Verifico, ademais, que nas discussões travadas na Assembleia Constituinte a questão do gênero na união estável foi amplamente debatida, quando se votou o dispositivo em tela, concluindo-se, de modo insofismável, que a união estável abrange, única e exclusivamente, pessoas de sexo distinto. (Lê trechos dos debates entre os deputados constituintes.) [...] Os constituintes, como se vê, depois de debaterem o assunto, optaram, inequivocamente, pela impossibilidade de se abrigar a relação entre pessoas do mesmo sexo no conceito jurídico de união estável.

É certo que o Judiciário não é mais, como queriam os pensadores liberais do século XVIII, mera bouche de la loi, acrítica e mecânica, admitindo-se uma certa criatividade dos juízes no processo de interpretação da lei, sobretudo quando estes se deparam com lacunas no ordenamento jurídico. Não se pode olvidar, porém, que a atuação exegética dos magistrados cessa diante de limites objetivos do direito posto. Em outras palavras, embora os juízes possam e devam valerse das mais variadas técnicas hermenêuticas para extrair da lei o 
sentido que melhor se aproxime da vontade original do legislador, combinando-a com o Zeitgeist vigente à época da subsunção desta aos fatos, a interpretação jurídica não pode desbordar dos lindes objetivamente delineados nos parâmetros normativos, porquanto, como ensinavam os antigos, in claris cessat interpretatio.

Para conceituar-se, juridicamente, a relação duradoura e ostensiva entre pessoas do mesmo sexo, já que não há previsão normativa expressa a ampará-la, seja na Constituição, seja na legislação ordinária, cumpre que se lance mão da integração analógica.

Ministro B - [...] Eu tinha também, presidente, e vou explicitar, uma outra dificuldade. A nossa legitimação enquanto Corte Constitucional advém do fato de nos aplicarmos a Constituição, a Constituição enquanto norma. E para isso nós não podemos dizer que nós lemos na Constituição o que nos quisermos, pois precisa existir um consenso básico. Temos de dizer por que nós estamos fazendo essa leitura, diante de um texto tão claro que diz que a união estável é a união estável entre homem e mulher. O que leva, portanto, alguns a entender aqui, menos do que um silêncio, um claro silêncio no sentido de vedar, mas que não é a consequência inevitável, tal como nos sabemos. Há outros direitos envolvidos que justificam a criação de um modelo idêntico ou semelhante ao modelo da união estável para essas relações existentes, com base já no princípio da igualdade, no princípio da liberdade, no princípio da não discriminação. É preciso dizer isso de forma muito clara, sob pena de cairmos num voluntarismo.

- Ministro C- A atuação judicante é sempre vinculada.

- Ministro D- Vossa Excelência me permite? Tem [a Constituição] princípios implícitos e explícitos. E se formos ao rol das garantias constitucionais, isso está em bom vernáculo. 
- Ministro A- Eu assinalei em meu voto que nós estamos ocupando o lugar que é do Congresso Nacional. Vossa Excelência mesmo acentuou que há uma certa inércia do Parlamento em regular essa matéria.

- Ministro E- Nós estamos dizendo que não há lacunas. Nós demos um tipo de interpretação superadora da literalidade, apontando que a própria Constituição contém elementos que habilitam esse julgamento a concluir pela paridade de situações jurídicas.

- Ministro C- Eu concordo com Vossa Excelência que a Constituição contém normas muito claras e direitos fundamentais que permitem a pretensão formulada. Se aqui vamos aplicar por extensão a norma constitucional ou vamos fazer por analogia, é uma discussão que no resultado vamos nos aproximar.

Como os próprios ministros apontaram, existem aqui duas técnicas diferentes que foram acionadas para o caso e que tentarei explorar. Quando esse processo foi julgado, perguntava-me qual a diferença fundamental dele para o processo anterior relacionado às cotas, ou mesmo ao primeiro processo apresentado no início do capítulo, quando o Supremo incluiu no rol dos beneficiários da imunidade tributária recíproca, determinadas empresas de economia mista. Nos três casos, a Constituição não prevê expressamente a decisão da corte. Como acontece inúmeras vezes - tendo em vista que as decisões que apenas repetem a norma constitucional não são as mais comuns -, as decisões criam coisas, inclui outras, "como se estivesse apenas aplicando a lei.

Em certa medida, as decisões da corte são sempre criativas - no sentido de Leach (2004), que define criatividade a partir de três elementos centrais. O primeiro é a combinação de coisas e ideias; o segundo é que esse processo de combinação é dirigido por uma vontade ou uma intenção; e o terceiro é a novidade da forma ou do resultado. No caso do STF, a vontade ou a intenção não é necessariamente do 
intérprete, mas engloba a ideia de vontade da lei e as intenções do legislador. A inovação como resultado, neste caso, parece precisar ser eclipsada, exatamente porque um dos "passes de mágica" da interpretação é a ideia de que o juiz está "aplicando a lei”.

Existem algumas diferenças técnicas nos casos apresentados. No processo das cotas existia uma política - um ato do poder público - que instaurava a reserva de vagas; esta foi submetida ao exame dos ministros, e conforme o entendimento revelado, realizava plenamente os comandos constitucionais. No caso agora em tela, não existe nada além da própria norma. $\mathrm{O}$ que nos parece é que neste caso o espaço entre a norma legal e a interpretação é mais difícil de ser ignorado. Se existe uma lacuna entre o direito e a realidade, existe também uma lacuna entre a lei e a interpretação. A mágica aqui parece mais complexa.

Um dos ministros deixa claro em seu voto que, no seu entendimento, existe uma omissão deliberada da Constituição em relação à possibilidade de a união entre pessoas do mesmo sexo ser considerada um tipo legal de família que possa ser abrangida pelo conceito legal de união estável. A "intenção do legislador constituinte originário" é verificável nos documentos que registram os debates da Assembleia Nacional Constituinte e constam nos autos. Se não existissem esses documentos, seria mais simples resolver a questão. Ainda assim foi possível ao ministro equacionar o caso com uma resposta que no seu entendimento é provisória, dada a partir da técnica de "analogia integradora".

No entendimento do ministro, como as uniões entre pessoas do mesmo sexo não são ilegais, ao contrário, estão protegidas pelos princípios constitucionais da igualdade e da dignidade da pessoa, devem, portanto, ser reconhecidas pelo ordenamento jurídico. Contudo, ainda segundo seu entendimento, a família constituída pela união entre pessoas do mesmo sexo é diferente daquela definida pela norma jurídica que expressamente diz homem e mulher. A solução técnica encontrada afirma que o rol de entidades familiares contidas na norma constitucional não é taxativo; a norma cita as entidades familiares mais comuns, mas não as únicas. As demais entidades familiares estariam implícitas na norma - o caráter da citação expressa de algumas entidades familiares teria então mero caráter exemplificativo. Ainda assim não era possível 
resolver o caso, dado que mesmo que seja uma entidade familiar, não seria a mesma definida para a união estável. Depois de reconhecer a união entre pessoas do mesmo sexo como entidade familiar, poderia então o ministro aplicar temporariamente, para efeitos legais, a norma que lhe é mais próxima, qual seja a união estável entre homens e mulheres. Nesse caso, uniões homoafetivas seriam - temporariamente - como se fossem uniões heterossexuais, apenas para efeito de proteção legal.

Embora com o mesmo resultado, o outro recurso técnico utilizado pelos ministros reside na superação da "literalidade", buscando a finalidade da norma. Não a finalidade dada pela "vontade do legislador" constatada nos documentos da Assembleia Constituinte, que serviu de baliza ao voto anterior, mas uma finalidade quase ontológica, que diz respeito à natureza da norma constitucional referente à união estável. Nesse entendimento, seria a união estável resultado de um mecanismo de inclusão, cuja finalidade está em garantir a equiparação legal entre esposa e companheira. Desse modo, não poderia o intérprete visualizar em uma norma de inclusão uma "restrição preconceituosa" que não permite incluir outras relações. É sensibilidade dos ministros que permite então uma interpretação "superadora da literalidade", a partir de um entendimento "generoso". Esse entendimento revela o “espírito da norma”, plenamente assentado no "espírito da Constituição".

Analisando as práticas de conhecimento e os atos jurídicos, Riles ( 2003) diferenciou dois gêneros de operação: expressivo e o instrumental. Conforme a autora os atos legais e as interpretações jurídicas desenvolvem os dois gêneros em sequência. No gênero expressivo ( que produz sentido, e portanto produz coisas) a produção de significado é temporalmente situada, sendo que "a expressão ou o sentidos da lei (definições) podem ficar datadas, separadas de seus objetos" (ONTO 2014, p.5). Assim, no modelo expressivo, caberia aos ministros, na esteira do argumento, unir, a partir de suas técnicas, a norma a seu objeto "atualizado". Como disseram os ministros no julgamento, as uniões homoafetivas são um fato do mundo que precisa ser protegido juridicamente, assim como as entidades que prestam serviços públicos típicos do Estado, ou a desigualdade étnico-racial. A norma jurídica, quando vista a partir do gênero expressivo, é constituída a partir de separação entre o objeto expresso e a realidade à qual se refere, e é exatamente por isso que ele pode ser disputado. Seguindo Wagner, Riles, argumenta que os atos legais, são "símbolos referenciais" 
(Wagner apud Riles 2003, p. 192), que operam no contraste entre o símbolo e o que ele simboliza.

Os sentidos da lei ou da norma são apreendidos pelos ministros a partir de um conjunto de técnicas, que estão nos discursos e também nas práticas documentais. E existem aqui, segundo Riles (idem) dois tipos de objetificação ${ }^{34}$ : aquela que opera tornando a realidade objeto da técnica e, portanto objetificando a realidade a partir de modelos racionalizados (Samuel, 2004), e outra, que ao invés de produzir uma separação entre a lei e o mundo, por meio da criação de significados, se torna ela mesma um objeto no mundo. Conforme Onto (2014): "Essas duas formas de tornar-se objeto dão ao conhecimento jurídico a característica de ser ao mesmo tempo um reflexo do mundo e uma coisa no mundo" (p.10)

Desse modo, as formalidades, os documentos, aos autos processuais e as técnicas de interpretação seriam objetos que não representam, mas "instanciam", seriam símbolos não referenciais no sentido de Wagner, que incorporaram aquilo que simbolizam. Uma decisão articula os dois gêneros. Ao mesmo tempo em que cria sentido se torna ela mesma objeto.

\subsection{A POLÍTICA DOS PROCESSOS E AS POSSIBILIDADE DE MUDANÇAS}

Diante de um uma dinâmica tão marcada pela ideia de continuidade implícita nas noções de segurança jurídica e previsibilidade, sempre me perguntava como era possível aos ministros mudar uma orientação jurisprudencial. Na realidade, poucas vezes ouvi dos ministros em plenário que uma jurisprudência estava sendo revertida, embora tenha ouvido algumas vezes dos ministros que existira a necessidade de uma reversão ou que determinada orientação jurisprudencial "aplicava mal o direito"..

\footnotetext{
${ }^{34}$ Riles parte da definição de Strathern, segundo a qual, objetificação é "o modo pelo qual pessoas e coisas se tornam objeto do olhar subjetivo ou de sua criação".
} 
Convém advertir que aplicar mal não significa necessariamente errar; não se ouve com frequência que os ministros erraram em determinada interpretação, pelo menos não dentro do Tribunal. Em grande parte das vezes a jurisprudência é estendida, limitada, mas não completamente revertida.

O modo mais simples de possíveis mudanças de entendimentos parece ser evidentemente a chegada de novos ministros à corte, com a aposentadoria dos mais antigos. De fato, com a chegada de novos ministros as chances de mudanças de orientações são maiores, ainda mais em jurisprudências firmadas em votações apertadas, em que um voto novo poderia mudar o quadro. Uma jurisprudência firmada com resultado muito apertado como um 6 a 5 parece ficar em suspenso, não para os efeitos da decisão, mas pensando no status daquela decisão no Tribunal. Mesmo que uma decisão como essa seja repetida em diversos casos, sabe-se que a posição pode ser mudada a qualquer momento, seja porque um novo ministro passou a integrar a corte, seja porque um dos ministros mudou sua posição, ou ainda porque um processo foi apregoado em sessões de julgamento em que não estavam presentes todos os integrantes da corte. Eis um trecho de julgamento para tentar esclarecer esse ponto.

Ministro Relator - O que se impõe ao Supremo é esclarecer se, sob o ângulo da dosimetria da pena, inquéritos e ações penais em andamento configuram antecedentes para efeito de fixação. A jurisprudência do Tribunal durante muito tempo inclinou-se no sentido de ser idônea a menção à existência de processos criminais em curso para efeito da apenação. Ficaram vencidos contra essa tese os ministros Celso de Melo, Sepúlveda Pertence, e posteriormente eu mesmo. $\mathrm{O}$ entendimento foi sendo suplantado à medida que foi renovada a composição do Tribunal. Assim, ao examinar o habeas 81.974, relatado perante a segunda turma, o ministro Gilmar Mendes, designado para redigir o acórdão, aventou indeferir o pedido à possibilidade de rever a posição então sufragada, o que veio a acontecer em 29/11/05. Sua Excelência defrontou-se uma vez mais 
com a problemática ao relatar o habeas 84.088; em que pese a ótica prevalente não ter sido alterada, verificou-se flexibilização na orientação. $\mathrm{O}$ redator do acórdão consignou que apenas a análise do caso concreto revelaria se a existência de inquéritos e processos em andamento poderia ser considerada para agravar a pena base. Àquela altura, a primeira turma já havia se manifestado pela impossibilidade de afastar a cláusula constitucional da não culpabilidade, ao apreciar o recurso 84.088, de minha relatoria. Essa compreensão logo se tornou dominante em ambos os órgãos fracionários, e assente hoje pela maioria. Os votos vencidos de ontem estavam a anunciar o surgimento de uma nova visão sobre o direito. Essa evolução também é verificável na doutrina.

Depois de quatro votos em sentido contrário à jurisprudência, começou um novo debate:

- Ministro A: Vossa Excelência me permite. No voto que proferi, eu disse que os dois órgãos fracionários estão decidindo no sentido de não levar em conta ações penais em andamento e inquéritos. Mas há mais: nós corremos o risco de uma decisão em recurso extraordinário com repercussão geral em sentido contrário ao que se todas as cadeias estivessem preenchidas. Por que os ministros Celso de Melo e Dias Toffoli afastam a incidência, não sei.

- Ministro B: Queria fazer uma observação. Eu, por exemplo, tenho o hábito de levar para a turma votos adequados à jurisprudência prevalecente, mas entendo que na hora do debate, no plenário, sobre a tese devo expressar a minha posição.

- Ministro A: Se os dois colegas que estão ausentes estivessem em plenário, hoje a decisão seria pelo desprovimento do recurso por $6 \mathrm{x}$ 
5. E estamos a julgar um recurso extraordinário, repito, sob o ângulo da repercussão e com o risco de adotarmos uma posição contrária a uma súmula do STJ e inclusive contra a doutrina

- Ministro Presidente: Todos sabem a minha posição, mas por pudor não participarei do julgamento, porque estive ausente durante parte substancial do debate. Suspendo o julgamento para colher os votos dos ausentes.

A jurisprudência nesse caso quase foi revertida por um acaso, pela falta de dois ministros na corte, e apenas permaneceu porque um dos ministros chegou atrasado à sessão. No entanto, não é esse o caminho ideal para uma mudança. O próprio ministro relator em seu voto deixa pistas das formas pelas quais jurisprudências podem ser revertidas. Conforme indicam os dados coletados, tanto em entrevistas como nos julgamentos, o impulso da mudança está nos destaques realizados pelos ministros nos processos, ainda que continuem a acompanhar a jurisprudência. Seriam um tipo de sinalização de que a tese jurídica que sustenta a decisão precisa ser rediscutida. Algumas vezes, como no caso citado acima, os destaques acompanhados por alguns ministros resultam numa flexibilização do paradigma, o que pode levar a uma mudança ainda nos julgamentos das turmas, embora não seja esse o espaço ideal para que uma questão seja rediscutida.

É o espaço do plenário, e os processos por ele julgados, que podem consolidar uma reversão de jurisprudencial. É no plenário que uma tese pode ser debatida e os ministros podem expor seus pontos de vista sem as limitações impostas pelas turmas. $\mathrm{Na}$ entrevista realizada com o ministro Gilmar $\mathrm{Mendes}^{35}$, sua Excelência me dizia, que opera nas mudanças de orientação uma lógica dos votos vencidos. Esses votos, com o passar do tempo, poderiam operar reorientações. Como indicativos de que o novo entendimento não foi abrupto, mas resultado de alguma coisa que já "vinha se desenhando". Para se referir ao potencial dos votos vencidos, o ministro usou a

\footnotetext{
${ }^{35}$ Entrevista 08/05/2012
} 
metáfora da semente lançadas nos julgamentos por votos vencidos podem germinar e darem seus frutos em outros momentos históricos, consolidando então novas ideias que vão prevalecer como majoritárias.

Quando entrevistei o ministro Fux $^{36}$ e lhe perguntei sobre a possibilidade da mudança, encontrei na resposta alguns elementos que parecem implicar uma reversão da jurisprudência. A primeira coisa que me disse o ministro estava relacionada ao tempo dos próprios ministros ocupando uma cadeira no STF. Ministros recém-chegados deveriam atuar acompanhando a jurisprudência e os votos dos ministros mais antigos. Qualquer movimento diferente causaria desconforto - no próximo capítulo serão expostos alguns casos. "Ninguém chega a um colegiado mudando tudo" - era o que dizia o ministro. O tempo dos ministros é, portanto um fator a ser considerado nas posições que irão sustentar.

O ministro ainda me disse, naquela ocasião, que havia uma jurisprudência na corte com a qual não concordava e que estava esperando o momento certo para tentar revertê-la. O momento certo está relacionado à antiguidade, mas também aos processos. Não se muda uma jurisprudência sem um processo cujo objeto demande que determinado precedente seja trazido ao debate. Caso não apareça no Tribunal esse processo, uma jurisprudência terá vida longa. Em alguns casos, a possibilidade da mudança é compartilhada entre os ministros e os advogados, em um tipo de política dos processos. Tentarei esclarecer esse ponto.

Durante o trabalho de campo tive a oportunidade de entrevistar alguns ministros aposentados do STF, entre eles o ministro Sepúlveda Pertence, que depois de se aposentar passou a exercer a advocacia. Durante a entrevista ${ }^{37}$, também perguntei ao ministro como se muda um entendimento. Ele me respondeu como advogado: "Não se desafia uma jurisprudência que acabou de ser firmada. Tem que ir aos poucos, corroendo-a desde a base até tentar voltar à cúpula”. Portanto, também existe uma temporalidade da jurisprudência. Para tentar revertê-la cabe aos advogados a leitura

\footnotetext{
${ }^{36}$ Entrevista realizada em 05/06/12. STF

${ }^{37}$ Entrevista realizada outubro de 2012, no escritório de advocacia do ministro.
} 
do que chamarei aqui de "conjuntura do Tribunal". Apresentar uma questão ao Tribunal na conjuntura imprópria é um "risco", que evidentemente sempre existe na medida em que ninguém pode afirmar com certeza qual será o resultado de um julgamento, mas, a conjuntura errada potencializa o risco.

O risco refere-se ao fato de que uma decisão é que ela vincula todas as outras similares em outros tribunais, uniformizando a resposta para determinada questão. Até que chegue ao STF, uma questão jurídica será respondida de formas distintas pelos tribunais inferiores, e isso favorece os interesses jurídicos de alguns advogados.

Essa conjuntura não apenas opera nas tentativas de mudar uma jurisprudência, na propositura de uma ação. Quando entrevistei o ministro Roberto Barroso ${ }^{38}$, ele narrou um dos casos em que atuou no STF (em que se discutia a questão do monopólio dos Correios). $\mathrm{Na}$ época, avaliava que o caso não deveria ter sido proposto, porque era uma ação muito "arriscada". Acrescentou o ministro: "começar a discutir essa questão numa ação direta é jogar o jogo inteiro numa cartada só".

A Procuradora da República, que entrevistei durante a pesquisa, também relatou quais os cálculos de um processo que são feitos de modo a potencializar as chances de o Tribunal julgar favoravelmente uma questão apresentada. É importante destacar que estamos falando aqui, sobretudo, de questões entendidas como relevantes, e não de recursos corriqueiros.

Os processos estratégicos, aqueles que você acha que tem um poder transformador, esses você calcula o tempo... Eu tenho uma questão que está aqui prontinha[apontava para estante da sala mostrando uma pasta] só que eu tenho uma liminar favorável do ministro Ayres Brito; então, pra que eu vou submeter esse processo agora, com risco

\footnotetext{
${ }^{38}$ Entrevista realizada em 21/05/12. Escritório de Advocacia.
} 
de perder? Eu preciso deixar que se criem fatos consumados. Todo mundo faz isso, os advogados fazem ${ }^{39}$.

"Todo mundo faz" inclui também os ministros do Tribunal, embora nem todos falem sobre isso. Os processos julgados pelo plenário permitem aos ministros também uma análise da conjuntura do Tribunal e do tempo de liberar um processo para julgamento. Assim como os advogados ou a procuradora, os ministros, em alguns casos, analisam as possibilidades de o plenário acompanhar um voto que será proferido.

O ministro Marco Aurélio me relatou a trajetória da ADPF 54, que tratava da possibilidade de interrupção de gestação de fetos anencefálicos. A petição que deu origem ao processo chegou ao Tribunal em 2004, com pedido liminar. Conforme o ministro, ele apresentou o pedido liminar para que fosse pautado no plenário, o que não aconteceu, resultando então numa decisão monocrática que concedeu o pedido no dia anterior ao início do recesso forense. Na volta dos ministros ao Tribunal, a liminar foi pautada para referendo e cassada pelo colegiado. O ministro decidiu "segurar" o processo no gabinete.

Quando cassaram a minha liminar, eu percebi que a concepção era contrária ao pano de fundo. Então coloquei o processo na prateleira, porque não envolvia interesses subjetivos. Quando o Tribunal liberou as pesquisas com células-tronco, muito embora por um escore muito apertado de $6 \times 5$, eu entendi que era a hora, e o resultado foi muito satisfatório. Existe uma avaliação pelos precedentes, pelos enfoques realizados até então. Nós temos sempre um termômetro. Aí devemos atuar no campo político-institucional.

${ }^{39}$ Entrevista realizada em 25/09/12 PGR 
A ADPF 54 foi julgada apenas em 2012, quase oito anos depois de ter sido apresentada. Na avaliação do ministro Marco Aurélio, caso fosse julgada antes disso, o resultado seria diferente. O tempo na prateleira, que ultrapassa o tempo procedimental, garantiu ao processo o resultado esperado por seu relator. Todavia, a liberação de um processo pelo relator não significa que ele será prontamente pautado; existe aqui uma aposta de que os ministros não irão retroceder em seus entendimentos e que o processo seja pautado sob determinada configuração do plenário.

A rigor, a gerência da pauta é prerrogativa do presidente do Tribunal. Os funcionários mais antigos e os ministros aposentados identificam que nos últimos anos os presidentes têm potencializado o poder de pautar o Tribunal, tornando a pauta um dos instrumentos do que chamo de política dos processos. Conforme o ministro Sepúlveda Pertence $^{40}$, a pauta se tornou objeto da política do Tribunal durante a presidência do ministro Nelson Jobim, que atuou no Congresso Nacional antes de se tornar ministro. Antes dele, disse o ministro Pertence, a pauta obedecia à ordem de liberação dos processos pelos gabinetes, ainda que já existissem pedidos dos relatores para que determinado processo pudesse ser antecipadamente pautado.

Me dizia a procuradora, que como o presidente tem o "poder da pauta", caso imagine que seu entendimento não será acompanhado pela maioria, ele irá segurar o processo. A lógica de segurar-liberar um processo, portanto, é pensada como um instrumento que pode potencializar determinado resultado, ainda que não existam garantias. Outro critério que aparece na pauta, são os processos considerados importantes para o presidente, que entrariam na pauta incorporando o julgamento ao "legado" da gestão. "Pautar um processo" ganha então, quase a mesma importância da decisão. Tendo em vista ainda que dependendo do tempo do processo na fila da pauta, a decisão pode se produzir sozinha. Explico. Se um processo levar anos para ser julgado, as situações a que eles se referem se tornam "fatos consumados" tornando qualquer decisão do tribunal sem efeitos. Ou ainda, é possível que o objeto do processo deixe de existir.

${ }^{40}$ Entrevista realizada outubro de 2012, no escritório de advocacia do ministro. 
Já no plenário existe a possibilidade do pedido de vista, que também segura a decisão de um processo. Em grande parte das vezes, quando acompanhei as sessões, o pedido de vista era feito quando havia um grande debate entre os ministros evidenciando não apenas a divergência entre os entendimentos, mas também dúvidas além das que normalmente ocorrem em um julgamento. Nesses casos algum ministro pedia vistas do processo para "estudar melhor os autos". Outro cenário possível, e sempre aventado por alguns funcionários do tribunal, é o pedido de vistas para "ganhar tempo". Nesse caso, o ministro trancaria a decisão, ainda que a maioria já tenho sido formada (que a maior parte dos ministros já tenha votado), para tentar construir novos elementos que pudessem convencer os demais de seu entendimento. O retorno do processo ao plenário pode demorar anos, tendo em vista que depende da liberação do voto- vista pelo ministro e da sua inclusão na pauta do tribunal.

Latour (2010) argumentou que a justiça de uma decisão não diz respeito a seu conteúdo, mas é efeito da forma. Quanto mais pesquisam, hesitam mais justa a decisão se torna. No caso do STF, na maioria dos casos a "justiça" da decisão ou a "boa aplicação do direito" é também efeito da circulação apropriada dos autos, da avaliação dos argumentos, da quantidade de volumes do processo, do número de precedentes anexados ao dispositivo decisório. Quando querem demonstrar a precisão da decisão alguns dos ministros usam a expressão "analisei os autos de forma vertical", isso daria a certeza de que a decisão é bem fundamentada tendo em vista que todas as possibilidades foram avaliadas. Não obstante, a decisão "justa" ou "correta" é também efeito de uma temporalidade específica. Nos processos subjetivos a demora na decisão implica sempre uma "injustiça", a falta de capacidade do tribunal em responder em tempo razoável uma demanda gera essa injustiça implícita qualquer que seja o conteúdo da decisão. Nos processos subjetivos é o "tempo da estante", que ultrapassa as temporalidades técnico burocráticas que pode garantir a uma decisão a qualidade de ser "justa", seja porque nesse tempo é possível "estudar mais o processo", seja porque determinadas questões precisariam de uma "conjuntura" favorável. Nos último caso, outros processos julgados pelo tribunal poderiam, ao longo do tempo, impulsionar o resultado esperado. 


\section{CAPÍTULO 4 - O JULGAMENTO}

Depois de percorrer o caminho que procuramos retraçar, passível de ser considerado "longo", a depender da perspectiva e das escalas de sua apreciação, um processo se aproxima do que é localmente definido como "sua resolução" quando adentra o salão do plenário. Processos julgados com decisões monocráticas, que, como sabemos, são aquelas tomadas apenas por um dos ministros, não têm a honra de ingressar na sala de julgamentos.

Levados pela Secretaria das Sessões, os volumes dos autos têm lugar de pouco destaque no salão do plenário e ficam aguardando sua decisão em bancos atrás de um dos porta-vozes do ministro relator. Os autos que veremos nesta sessão têm mais de 50 mil páginas. São compostos de diversos documentos, entre relatórios de perícia, transcrições de depoimentos, petições da defesa e da acusação. O processo que irá guiar a apresentação do ritual de julgamento é uma Ação Penal Pública, um processo de natureza criminal que terá como resultado final a prisão dos denunciados.

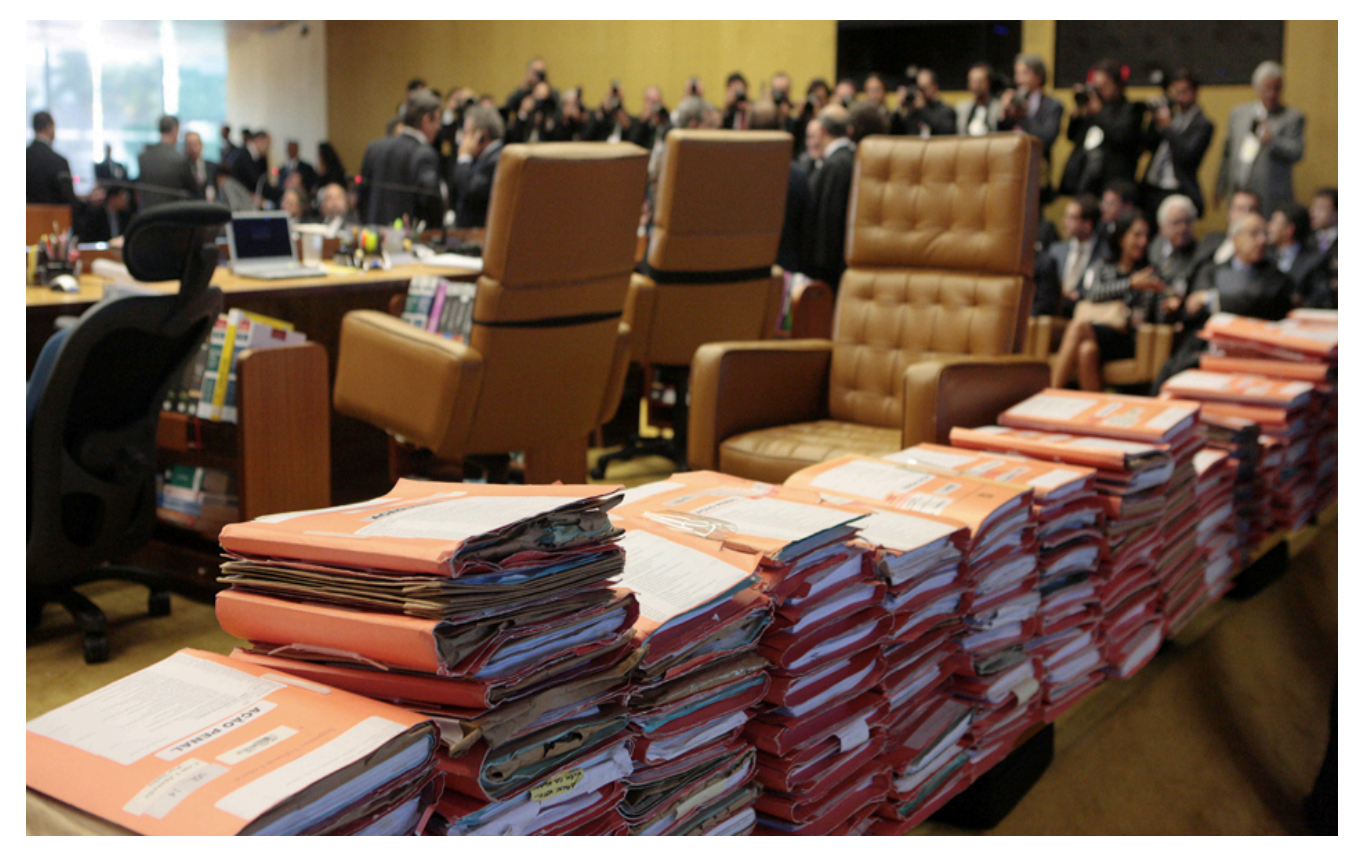

Figure 7 - Autos da AP 470. Fonte STF 
O que se pretende evidenciar a partir da descrição do julgamento da AP 470 são os aspectos rituais e performativos de uma sessão do STF que possibilitam a compreensão das estratégias de convencimento, a posição dos agentes e os aspectos retóricos da produção jurídica no STF. Além disso, esse processo penal permite articular as noções locais de verdade real e processual que dão suporte às conclusões do processo. Busca-se também descrever como são os julgamentos de modo geral e a ação penal nesse sentido aparece como figura que ilustra as dimensões que se intenta ressaltar

Peirano (2001) já observara que rituais de uma sociedade apenas "ampliam, focalizam, põem em relevo e justificam o que já é usual nela”. Desse modo, o ritual do julgamento não se separa do modo como tudo é operado antes que ele aconteça. No ritual do julgamento, como em toda produção judicial do Tribunal, conforme argumenta Latour (2010), cada pequeno episódio rearranja os elementos de tensões, vitórias e atualizações. Precedentes são rearranjados, reputações são feitas e desfeitas, revisões de orientação são realizadas, e em meio a tudo isso não é possível distinguir quais desses veículos são o direito puro e quais são meros acompanhamentos. Ao longo da tese pretendeu-se retraçar os caminhos de produção de um processo a partir dos lugares de sua produção, dos procedimentos envolvidos, das relações que se movimentam com os autos, das técnicas que organizam, classificam e produzem as decisões. O que se tentou demonstrar é que o direito não está precisamente em algum desses lugares, mas um pouco em todo o fluxo do processamento. Durante o julgamento todos esses elementos aparecem como garantia, fundamento de que as decisões que serão constituídas carregam legitimidade e a "justiça", ainda que apenas em seu aspecto formal.

As luzes do plenário se acendem no início das tardes das quartas e quintas- feiras. É quando os funcionários do Tribunal - seguranças e servidores do cerimonial começam a organizar o salão, reservando lugares aos representantes das partes dos processos que estão na pauta. A pauta é publicada elencando uma dezena de processos a serem julgados no dia, porém nunca é cumprida em sua totalidade. E processos que se acham na pauta e não são julgados, não necessariamente estarão na pauta do dia seguinte, podendo entrar novamente na fila de espera e demorar mais alguns meses ou anos para voltar ao plenário. 
Os assessores dos ministros também chegam ao plenário no início da tarde. Trazem, dos gabinetes em que trabalham, pastas com papéis, livros, além da toga dos ministros. Às duas horas da tarde, as portas de vidro da frente do prédio principal são abertas. Na entrada, passando pelo detector de metais, precisamos nos identificar, com número da carteirinha da $\mathrm{OAB}$ (para os profissionais advogados), ou com o número do RG para os demais. Os advogados detêm uma identificação particular que os autoriza a circular pelos espaços do STF.

Cadastrados, recebemos uma etiqueta, na qual está gravado o nosso nome e que deve ser colada em local de fácil visualização. Somos então autorizados a entrar no salão do plenário, devendo aguardar sentados o início da sessão. Existem várias regras que devem ser seguidas por quem pretende assistir ao julgamento, que vão desde o traje obrigatório - terno e gravata para homens, e vestidos com mangas, tailleurs ou ternos (calça $^{41}$ e blazer de manga comprida) para mulheres - até o modo de sentar nas

${ }^{41} \mathrm{O}$ uso de calça para mulheres foi proibido até o ano 2000, quando, em sessão administrativa, os ministros aprovaram a mudança do traje, permanecendo ainda obrigatório o uso do blazer. Embora "liberado", apenas em 2007 a ministra Carmem Lúcia entrou no salão de julgamento vestindo calça, e a cena não se repete com frequência. Na mesma sessão administrativa, um dos ministros propôs uma flexibilização ainda maior, mas restou vencido e ainda se segue a normativa do Tribunal, segundo a qual: "não são permitidos, a qualquer título, o ingresso e a permanência nas dependências do Tribunal de pessoas com trajes em desacordo com o cerimonial, a formalidade e o caráter solene da Corte, ou que sejam atentatórios ao decoro" (Ordem de Serviço 11/1999). Eu mesma presenciei diversas vezes pessoas sendo impedidas de entrar no prédio por conta dos trajes inadequados, e também passei por duas situações dessa ordem. A primeira, no início do trabalho de campo, quando fui barrada porque vestia uma calça mais curta. De outro momento em que quase fui impedida de entrar, reproduzo aqui o diálogo com os seguranças do Tribunal:

- Segurança: Doutora, infelizmente o tecido do seu blazer não está de acordo com as normas do Tribunal.

- Eu: As regras mudaram? Porque já assisti a uma sessão com esse blazer sem nenhum problema. É veludo cotelê, última moda (tentava eu, de modo inadequado, ser engraçada). Segurança: Bom, vou chamar o chefe do cerimonial. 
poltronas estofadas. Garapon (1997) chama atenção, em sua pesquisa sobre os rituais do Judiciário, que o protocolo obrigatório dos rituais judiciários não seriam meros “acidentes" na prática jurídica, senão determinantes de sua essência, e embora “condenados às aparências”, são condições necessárias ao sistema de justiça.

Antes que os ministros possam entrar no salão do plenário, seus assistentes se dirigem ao "salão branco" para realizar o "ritual da toga", quando os ministros são vestidos com a capa preta que deverão usar enquanto estiverem no plenário. Conforme Garapon (idem), a toga, assim como outros elementos do ritual judiciário - como espaço, tempo, os atores e gestos - constitui uma experiência sensível de um julgamento que tem por objetivo uma ruptura com a experiência comum. À toga, em especial, o autor atribui a função de ser como um objeto de purificação, que investe um juiz em seu papel institucional (p. 85).

Os funcionários do plenário, antes da entrada dos ministros, estão sempre atentos às indicações do secretário da sessão. Ao ser ouvido um estalar de dedos, esses servidores tomam suas posições - próximo aos acessos das bancadas dos ministros - e o secretário toca um sinal. O público é orientado a se levantar quando da entrada dos ministros, que, em fila e conduzidos pelo presidente, se dirigem às bancadas do plenário. À espera dos magistrados estão seus assessores, que lhes puxam as cadeiras. Apenas um dos ministros libera seu funcionário da "gentileza".

O nosso julgamento, em sessão extraordinária, teve início numa segunda- feira, dia 3/8/12. Já na entrada do STF estava tudo um pouco diferente do usual. Um número maior de seguranças vestia uniformes pretos e se achavam nos portões que dão acesso ao prédio principal. Existia um receio de que houvesse manifestações no Tribunal devido à grande repercussão das denúncias que compõem a ação penal. O número de

Cerimonial: Pode deixar a doutora entrar, ela sempre usa esse mesmo blazer (ficava claro que era o momento de investir em um novo traje).

Em situações excepcionais, os funcionários do cerimonial emprestam às mulheres sem blazer um paletó masculino para que entrem no plenário. 
jornalistas, câmeras fotográficas e filmadoras era também extraordinariamente maior. Um julgamento histórico estava para começar. Nas palavras do ministro Celso de Mello, o mais importante da história recente do Tribunal, ou seja, depois da promulgação da Constituição de 1988.

Nas descrições dos capítulos anteriores assistimos a outros julgamentos históricos, alguns também qualificados como "os mais importantes". O STF, cada vez mais, se torna um agente importante na vida política do país, sobretudo a partir de seus “julgamentos históricos”, fenômeno este identificado pelos juristas e pesquisadores do direito como "judicialização da vida e da política" (Werneck Vianna, 1996). Conforme Schuch (2008):

Tais denominações referem-se ao processo de expansão das reformas judiciais e dos projetos de modernização e democratização da sociedade através da via judicial, o que vem ocorrendo mais intensivamente desde os anos 1980, tendo como consequência uma crescente visibilidade das cortes de justiça e das leis. (p. 9)

Durante o tempo que passei no Tribunal, a cada julgamento histórico que acompanhei, e foram pelo menos quatro, a impressão era que o Tribunal, ao "fazer história" através de suas decisões, recupera a ideia de que fala em nome do "povo", ainda que não tenha sido eleito por ele. Os representam na medida em que falam em nome da Constituição, do poder constituinte originário emanado do "povo". Nesse sentido, existe mais "sociedade" no direito como afirmou Latour (2010) do que na própria sociedade. Contudo, na analítica dos meios e fins, proposta por Riles (2011), ainda que os fins sejam potencializados pela sensibilidades dos juízes que evocam uma ideia de justiça menos formal, existe a necessidade de um "salto técnico".

No caso agora em tela, a importância do julgamento parece estar relacionada a duas questões principais. A primeira delas diz respeito à natureza do processo: trata-se de um processo criminal poucas vezes julgado pela corte. Uma segunda questão são os 
nomes que estampam a capa das pastas de cor alaranjada - 307 volumes. Impressos na primeira folha dos autos estão nomes de políticos, deputados, ex-ministros e banqueiros denunciados por um suposto esquema de corrupção, o qual a imprensa apelidou de "mensalão".

A denúncia trata de um esquema de compra de votos que envolvia o Poder Executivo, na figura de ministro chefe da Casa Civil, e alguns deputados da base aliada do governo. A fonte de recursos para esses pagamentos teria origem em um esquema de desvio de dinheiro público realizado por meio de contratos publicitários e empréstimos bancários ilícitos. O caso mobilizou a imprensa brasileira, que esteve presente em todo o julgamento, acompanhando de perto a trajetória da decisão.

No setor reservado aos advogados dentro do plenário, todas as poltronas estavam ocupadas. Os mais reputados advogados criminalistas estavam lá sentados, alguns deles assessorados por outros advogados que compõem suas bancadas - esse é o nome que se dá ao quadro de advogados de um escritório.

Como se trata de uma denúncia apresentada pelo MP diretamente ao STF, por isso mesmo originária, o Tribunal, através do relator do processo, protagonizou quase todos os procedimentos que envolveram a apuração dos "fatos apresentados na denúncia”. Em outras palavras, o Tribunal participou da produção probatória do processo, embora nenhum dos ministros haja tido contato direto com os réus da AP durante o curso da instrução processual - denominação dada à fase em que um processo é composto. Não são os ministros aqueles que acompanharam e realizaram os depoimentos dos réus ou das testemunhas; para isso foram designados outros juízes. Desse modo, o contato dos ministros com os resultados das investigações se deu por meio de documentos anexados aos autos.

As ações penais são os únicos processos criminais nos quais os ministros podem examinar as provas de um processo. Em habeas corpus, por exemplo, outro tipo de processo criminal que chega ao STF, a rigor, os ministros apenas avaliam as decisões de instância inferiores com base em seus parâmetros jurisprudenciais. Contudo, não nos deteremos aqui nas trajetórias de processamento dessa ação. O processo servirá 
tão só como referência para pensar o julgamento plenário como espaço de articulação de formas ritualizadas e dinâmicas performativas de constituição das decisões.

Convém advertir que a descrição do julgamento tem a AP 470 apenas como referência. Não pretendemos aqui reconstituir todo o julgamento, mas tão somente os aspectos que permitem compreender a dinâmica da decisão nesse espaço. Os trechos da ação penal selecionados são ilustrativos das formas de debate das disputas de convencimento, dos protocolos das relações. Nesse sentido, pelo fato de ser um julgamento que ocupou o plenário por alguns meses, e em que os diversos elementos que constituem os julgamentos aparecem num único caso, a AP 470 ajuda a capturar a dinâmica de uma sessão.

\subsection{A DEFESA E A ACUSAÇÃO}

Quem abre a sessão de julgamento é o presidente do Tribunal; solicitando ao secretário da sessão que faça a leitura da ata da sessão anterior. Aprovada a ata, um novo processo é apregoado e a palavra é cedida ao relator do processo, o primeiro a falar. A ordem dos pronunciamentos é bastante rigorosa, pois uma possível inversão pode anular todo o julgamento. Conforme destaca Eli (2012), o ritual em questão está fortemente ancorado numa dimensão formal inflexível. Isto é, está firmemente regido por um restritivo e inelástico protocolo de condições de "felicidade" (no sentido de Austin, 1975; e de Tambiah, 1985).

A leitura do relatório pelo ministro responsável, na maioria das vezes, constitui o primeiro contato dos demais ministros com os termos das alegações realizadas no processo. Ainda que os autos possam circular pelos gabinetes antes do julgamento, é o relator que detém a maior quantidade de informações do processo. No caso da AP 470, pelo tamanho e natureza do caso, o Tribunal designou por sorteio um revisor para o caso.

Durante a leitura do relatório, os demais ministros fazem anotações e solicitam informações aos seus assessores, que estão sentados nas primeiras poltronas, logo atrás dos "seus ministros". Esses assessores de plenário, quando sobem até as 
bancadas devem vestir também uma capa preta, ainda que seja mais curta que a toga usada pelos ministros. Na realidade, ninguém pode subir ao espaço dos ministros sem vestir a capa, e até mesmo o fotógrafo do Tribunal circula pela sessão vestindo a "capinha".

Capinha é o termo que identifica os assessores de plenário, responsáveis por entregar aos ministros as folhas com os votos cada vez que um processo é apregoado, garantindo que o voto lido diz respeito ao processo em julgamento, pois a cada sessão ordinária mais de um processo é julgado. Esses assessores são funcionários dos gabinetes, que trabalham também com os processos; grande parte deles é formada por funcionários terceirizados.

Após a leitura do relatório, as partes do processo, representadas por seus advogados, devem realizar seus pronunciamentos. Quem fala primeiro, pela ordem legal, é sempre a acusação. Na ação penal esse era o papel do procurador-geral da República, responsável pela denúncia. O PGR está presente em todas as sessões do Tribunal, embora nem sempre seja parte de um processo. Quando não compõe os autos como parte, sua intervenção no julgamento e nos autos se dá como “fiscal da lei”. Nesses dois tipos de intervenção, o procurador se acha sentado no mesmo lugar, à direita do presidente, em frente à bandeira da República, e é também auxiliado por um capinha. $\mathrm{O}$ valor do pronunciamento do PGR e dos advogados deve ser o mesmo, embora fisicamente estejam em lugares desproporcionais. Um dos advogados que subiu à tribuna durante o julgamento da AP pontuou em sua fala essa diferença de posição, de modo um tanto caricato:

Eu quero dizer a Vossa Excelência, Dr. Gurgel, da diferença que é estar aqui nessa tribuna sagrada e estar aí sentado onde Vossa Excelência está. Primeiro, Vossa Excelência representa o Ministério Público e está diariamente aqui tendo a honra e o prazer de conviver diariamente com os ministros da mais alta corte do país. Ao advogado resta a angústia, resta o nervosismo de vez ou outra ocupar essa tribuna para defender a liberdade do cidadão. Quando a corte se 
levanta, e nós advogados nos levantamos em reverência a Vossas Excelências, Vossa Excelência entra junto. Certa feita um cliente meu viu o procurador-geral entrar, ficou apavorado e me perguntou: Ele vota? Eu tive que explicar a ele que não votava. Depois, no momento em que termina e que, educadamente o presidente dá por encerrado e começa então o lanche, nós ficamos aqui e nenhuma barra de cereal eu posso pegar. Eu quero apenas dizer que Vossa Excelência senta à direita do presidente, fala como se estivesse em casa. Eu vi Vossa Excelência falar reservadamente com o presidente ou com o ministro Celso de Mello, isso não é nada errado, mas imagina se eu sair aqui e for falar no ouvido do ministro presidente... Vai ser uma perplexidade geral.

Nos espaços de argumentação oral, a prática jurídica realiza sua dimensão como arte, da qual falava o ministro Barroso no trecho da entrevista citado no início do capítulo anterior. Nas falas existe um aspecto retórico valorizado pelos advogados, além de estratégias persuasivas. Não tive a oportunidade de entrevistar o PGR, mas entrevistei a vice-procuradora, que me contou sua estratégia de organização de uma sustentação oral. Disse-me ela:

Eu acho que a sustentação oral pode ser uma coisa muito pessoal. Do meu ponto de vista, eu organizo a fala, separando os argumentos do processo que me parecem mais persuasivos. Eu também não leio, pois acho que a leitura dispersa e, embora se possa se perder em qualidade, se ganha. Eu penso que falar mais duro, mais assertivamente, é melhor, mas qualquer estratégia é válida.

A primeira coisa que é importante é saber direito, ou saber o processo, o que está sendo discutido ali e defender bem esse 
argumento jurídico. Mas volto a dizer, eu acho que parte do poder de persuasão está na capacidade de falar sem ler.

Uma sustentação depende também do espaço judiciário em que se está. Geralmente, se um advogado é muito bom no tribunal do júri, no Supremo não vai ser, porque é um tribunal que está preocupado em julgar mais tecnicamente do que emocionalmente.

A diferença apontada pela procuradora entre o técnico e o emocional diz respeito aos julgadores. Em tribunais do júri ${ }^{42}$, os acusados são julgados por uma composição de "pessoas comuns" que poderiam ser convencidas por argumentos de ordem emocional, ocupando essa categoria lugar de oposição ao jurídico como técnico. Diferentemente do julgamento no STF, em que quem julga tem o domínio da técnica do direito. O convencimento dos ministros estaria baseado apenas nos argumentos jurídicos do processo.

A sustentação oral, tanto da Procuradoria como dos advogados, se concentra em convencer os ministros vogais, ou seja, aqueles que estudaram menos o processo. $\mathrm{O}$ consenso entre os advogados entrevistados e a vice-procuradora é que é praticamente impossível, durante a sustentação oral, convencer o ministro relator caso ele já não o tenha sido durante o processo, com todos os documentos entregues. A posição do relator, como aquele que estudou os autos durante todo o tempo do processamento, estaria fechada, e seu voto, pronto, impresso, aguardando para ser anexado aos autos. A fala dos advogados e do procurador não é muito diferente do que foi escrito e consta nas petições. Desse modo, o relator já conhece todos os argumentos.

Embora alguns dos ministros também cheguem ao plenário com um tipo de “disposição" para o voto, é a eles que as sustentações se dirigem, já que estudaram menos o processo - quase sempre, um ou dois dias antes de sua chegada ao plenário.

${ }^{42}$ Ver SCHRITZMEYER 2002. ELI (2012) 
Certamente não foi esse o caso da ação penal. Os ministros vogais passaram mais tempo analisando os autos, tendo em vista não apenas a complexidade do caso, mas também seu tamanho. Seria impossível conhecer minimamente o que se passa com dois dias de antecedência. Certa vez, ouvi de um advogado no plenário que a esperança dos advogados residia em que os demais ministros não chegassem à sessão com voto escrito, assim a possibilidade de serem convencidos seria maior, escrever o voto cristalizaria uma posição, embora, se saiba nem sempre seja assim.

Seguindo a ordem do processo, que é também a ordem estabelecida pela lei, chega a vez de a defesa ocupar a tribuna. Os advogados também usam capas pretas, algumas delas com detalhes em tecido branco nas mangas, como babados. Embora o tribunal disponibilize togas que podem ser usadas durante o julgamento, os advogados costumam levar suas próprias capas pretas. Em um julgamento comum, uma sustentação oral não pode passar de 15 minutos, tempo marcado em um relógio digital colocado em frente aos advogados na mesa que era ocupada antigamente por um taquígrafo $^{43}$ - embora essa figura não exista mais, sua mesa continua no meio do plenário. Na maioria dos casos julgados, nem mesmo ocorrem as sustentações, que não são obrigatórias para todos os tipos de processos. Contudo, em processos criminais a fala dos advogados não é apenas desejável, mas obrigatória. No caso da ação penal, por se tratar de um processo volumoso, o tempo de defesa estabelecido foi de uma hora para cada um dos 38 acusados. Desse modo, durante alguns dias se ouviu exclusivamente a fala das defesas.

${ }^{43}$ Atualmente existe um setor do Tribunal que realiza as transcrições dos julgamentos. Esse documento produzido pela seção é incorporado ao acórdão. Na realidade, um julgamento gera diversos documentos: a ata da sessão, que comprova que determinado processo foi julgado e seu resultado, a parte dispositiva da decisão, que é a síntese do julgamento, e a transcrição dos votos e dos debates, que é anexada ao acórdão. Ainda no acórdão são elencados todos os precedentes citados, toda a doutrina mencionada em todos os votos e uma indexação do caso e da decisão. 
A fala dos advogados, embora utilizando recursos persuasivos diferentes, segue um tipo de protocolo. Começam sempre a defesa homenageando os ministros e exaltando a "história da corte". Quase como um tipo de reverência formal obrigatória. Pela legislação que rege as relações formais e as liturgias do direito, não existe hierarquia nem subordinação entre magistrados, advogados e procuradores. Nem mesmo entre os ministros, o que não significa que em instituições jurídicas não se pessoalizem, individualizem ou hierarquizem relações que no plano formal deveriam ocorrer de outra forma (Bevilacqua e Leirner, 2000, p. 125). Não obstante sejam partes complementares de um processo, juízes, procuradores e advogados ocupam posições estruturais assimétricas.

A tribuna dos advogados é considerada como um "espaço sagrado". Nela os advogados parecem carregar um pouco do que Rui Barbosa chamou, em pronunciamento datado de 1892, no STF, de "respeito quase supersticioso" diante do “oráculo da nova Constituição": o Supremo Tribunal Federal. Talvez seja exatamente porque o patrono do direito brasileiro assim como outros grandes juristas ocuparam a tribuna no STF que esse respeito supersticioso apareça com mais vigor, tomado de uma carga maior de significado. Não deixa de ser interessante observar que alguns dos advogados carregam amuletos durante julgamentos que participam, que podem ser apenas a sua própria toga, ou cópias especiais da Constituição Federal. Também ouvi que alguns advogados não gostam de contar os votos antes do julgamento, evitando fazer previsões matemáticas acerca dos resultados, pois “dá azar”. Embora conheçam as tendências dos ministros, sempre é possível que os resultados sejam surpreendentes.

Ainda seguindo as sustentações orais, um dos advogados falou do sentimento de "subir à tribuna":

Conversando no escritório sobre esse julgamento, um determinado dia um dos estagiários me colocou: José Luiz, como um advogado se sente ao subir na tribuna, quando ele vai colocar a tese da defesa? 
Essa pergunta me fez lembrar exatamente o tempo em que eu fui estagiário e um diálogo que eu tive com um dos maiores advogados e oradores que eu conheci na advocacia, Dr. Waldir Troncoso Perez. $\mathrm{Eu}$ fiz essa mesma pergunta. Como ele se sentia quando ele subia na tribuna? Ele me falou assim: Zé Luiz, o advogado que subir na tribuna e não ficar com a mão gelada, um certo frio na barriga, com a emoção à flor da pele, ele certamente não fará uma sustentação razoável.

Então eu disse ao estagiário que, quando um advogado sobe na tribuna, ele fica nervoso, e neste caso, um pouco mais, não diria que pela complexidade do tema, mas são vários advogados, vários acusados, o caso tem uma repercussão, então é inegável que essa emoção fique um pouco mais aflorada. Mas ela começa a diminuir quando eu me lembro de uma frase do eminente ministro Marco Aurélio, frase essa que o ministro já mencionou nesse julgamento. $\mathrm{O}$ processo não tem capa. Essa frase que o ministro repete é um tranquilizador para esse advogado, porque o processo não tem capa, não tem cor, não tem partido político; o processo tem ou não tem provas e, sendo um julgamento com base nas provas dos autos, a tranquilidade chega.

Ao contrário do MP, que se apoia em provas extrajudiciais, em depoimentos de tumultuadas sessões de comissões parlamentares, artigos de colunistas respeitados, e buscou inclusive inspiração em Chico Buarque de Holanda, quero dizer que essa defesa vai se apoiar no devido processo legal, na Carta Magna (...)

Ficar nervoso em pé diante da tribuna é sinal de respeito - confessou-me um dos advogados durante o julgamento -, respeito não apenas aos magistrados sentados à frente, mas, sobretudo, ao processo. "Nós estudamos e estudamos de novo todo o processo. Ninguém melhor do que um advogado para conhecer cada página dos autos. 
A partir desse estudo temos então uma tese que foi defendida nos autos e que será defendida na tribuna. Mas sempre existe um receio de não conseguir expor de modo satisfatório tudo que se tem a dizer. Ninguém aqui veio declamar, fazer um exercício retórico, pois existem centenas de pessoas afetadas em um processo. É o compromisso com elas que causa mais nervosismo, principalmente agora que o que está em jogo é a liberdade das pessoas". Parece-me ser mais do que isso: a sustentação oral coloca em destaque o enunciatário e sua reputação, que também está sendo construída naquele espaço. Embora as falas dos advogados não se tornem precedentes para outros casos, elas constituem precedentes nesse universo. Existem aqui também "critérios estéticos" (Riles, 2011) a ser observados.

A qualidade de uma boa defesa, segundo os advogados com quem conversei, está na clareza com que é enunciada, na firmeza da fala, na convicção do advogado e na correlação fiel com os autos - ainda que a perspectiva de um advogado sobre o que foi produzido no processo seja balizada pelos interesses de seus representados. Conforme me disse o ministro Roberto Barroso quando o entrevistei, um bom advogado é aquele capaz de contar sua história fazendo com que qualquer pessoa ache que aquilo corresponde ao senso comum.

Devo confessar que não apenas neste julgamento, mas em vários outros, fui convencida pelos advogados com suas falas preparadas e até mesmo emocionantes. Parecia-me naqueles momentos que não tinham como estar errados. Cheguei a ser convencida em causas nas quais não tinha sequer uma vaga ideia do que estava sendo discutido. Quando comentei o fato com um dos assessores do gabinete do ministro Marco Aurélio, ele riu e me disse: "Deve ser por isso que você é antropóloga e não juíza; e também por isso que eles são advogados e estão no Supremo".

O "senso comum" apontado na fala do ministro Barroso está presente também nas sustentações orais, quando os advogados articulam seus argumentos a partir da jurisprudência do Tribunal. Ao dizerem "nesse sentido, cito precedente desta corte", colocam a autoridade do argumento em um suposto "senso comum" do Tribunal.

A fala dos advogados no julgamento da AP 470 direcionava-se a uma questão particular do processo. O receio das defesas era de que o "clamor" do público e da 
imprensa pudesse interferir no juízo dos magistrados, tendo em vista a repercussão das denúncias apresentadas no processo. Reivindicavam aos ministros que aquele fosse um julgamento "técnico" e não "político. Não pretendo medir aqui o quão políticos ou o quão técnicos foram os votos. A política abordada no capítulo é muito mais uma política do direito, relacionada às disputas em torno do processo, do que uma política que extrapola o universo jurídico.

\subsection{A CENTRALIDADE DO RELATOR}

Terminadas as sustentações, a palavra volta aos ministros para que a decisão comece a ser definida. A partir desse momento, os advogados só podem ocupar novamente a tribuna caso tenham alguma questão de fato. Se algum deles subir à tribuna, pedindo a palavra e usando a expressão "Pela Ordem", o presidente irá indagar: "É questão de fato ou é de direito?". Apenas a primeira alternativa garantiria ao advogado o direito à fala. As questões de direito, nesse momento do julgamento, estão restritas apenas aos ministros.

Ao retomar a palavra para começar a colher os votos dos ministros, o presidente afirmou, diminuindo a ansiedade e a preocupação dos defensores: "Esse será um julgamento "técnico". Por ser a figura que distribui as falas no plenário, o presidente passa a palavra novamente ao relator, desta vez para colher seu voto, que se concentra num primeiro momento nas questões preliminares do processo, anteriores ao mérito da ação. Foram diversas questões apresentadas em regime preliminar e serão aqui abordadas apenas duas delas.

A primeira preliminar que me chamou atenção foi apresentada por alguns advogados e reivindicava que o relator do processo se declarasse impedido no julgamento, alegando que o ministro estaria sob suspeição porque havia feito declarações públicas emitindo juízos em relação aos denunciados antes do julgamento, caracterizando uma ilegalidade. Conforme o voto do relator, os advogados teriam usado na petição termos não condizentes com o "respeito" que devem ter em relação à corte e aos ministros. 
Ainda durante seu voto, que rejeitou a preliminar, o relator solicitou aos demais ministros que o Tribunal encaminhasse à Ordem dos Advogados do Brasil representação contra os defensores.

Relator - Essa preliminar diz respeito a ataques puramente pessoais feitos à minha pessoa. Em alegações apresentadas, esses advogados afirmam que eu teria agido de forma parcial na condução do processo, proferindo decisões com finalidade midiática. Tais afirmações, senhor Presidente, para dizer o mínimo, ultrapassam o limite da deselegância e da falta de lealdade e urbanidade que se exige de todos os atores do processo. [...] Ressaltam que eu teria mencionado no relatório da denúncia que estava simplesmente tentando dizer com outras palavras o que estava na denúncia do procurador. Eu ultrapasso essa preliminar sugerindo à corte que aprecie a possibilidade de representar perante a Ordem dos Advogados do Brasil contra esses advogados.

Ministro A - Eu acompanho o relator, rejeitando a preliminar em relação ao encaminhamento do ofício à Ordem. Já tive oportunidade de enfrentar esse tema em outro caso na turma, e lá aprendi com o ministro Marco Aurélio que é da tradição da corte não fazer esse tipo de encaminhamento. Seguindo a tradição da corte, peço vênia para acompanhar a divergência.

Ministro B - O que colho do voto do relator, que teve a gentileza de nos encaminhar há pouco... colho que numa peça jurídica, nas alegações finais se teria dito que agiria o relator muito mais com olhos voltados para a mídia. Eu não sei o que poderiam falar sobre mim. Em passo seguinte, qual seria a expressão, que não vejo aqui, a consubstanciar algo a alcançar em si o perfil que a sociedade brasileira tem do relator? 
Ministro decano - O Supremo Tribunal já advertiu que o Poder Judiciário não pode permitir que se cale a voz do advogado, cuja atuação livre e independente há de ser permanentemente assegurada. $\mathrm{O}$ respeito às prerrogativas profissionais do advogado constituem uma garantia da própria sociedade. Eventuais excessos muitas vezes são cometidos. O eminente advogado aqui desta tribuna revelou que não teve o intuito de ofender o eminente ministro relator.

Ministro relator - Porque eu não li a totalidade do texto.

Ministro decano - Mas eu li.

Ministro relator - Vossa Excelência leu a petição? Não, Vossa Excelência leu o trecho que eu, por pudor, resolvi transcrever no meu voto. Eu não quis transcrever a integralidade das ofensas.

Ministro decano - Talvez devesse ter feito isso.

Ministro A - Nada impede, e eu não faço essa proposta, que se risquem as expressões dos autos.

Ministro relator - Eu proponho isso.

Ministro B - Aí teremos de conhecer as expressões. Complica a solução.

A partir desse debate é possível mensurar a importância do voto do relator, menos no sentido de que seu voto será acompanhado, e mais por ter o relator um acesso privilegiado aos autos. O "procedimento técnico" de extrair das petições o que deve constar no voto e no relatório, realizado pelos gabinetes, é no julgamento de fundamental importância, pois a conclusão do voto importa menos do que os elementos dos autos que ali se acham. O voto de relator, a rigor, é o único que articula 
todos os argumentos levantados nos autos. Os demais ministros se concentram em partes específicas dos processos.

A qualidade do relatório e do voto do ministro relator pode ser avaliada pela quantidade de dúvidas sobre os autos que emergem no debate entre os ministros. Correndo o risco de parecer confiante demais, não me parece que os ministros intencionalmente ocultem argumentos ou documentos presentes nos autos com vistas a induzir os demais ministros a erro. Até porque um mesmo documento que sustenta uma conclusão pode sustentar conclusão em sentido contrário. E não estou dizendo que não existam estratégias de convencimento entre os ministros; nelas nos deteremos mais adiante

Atualmente é possível aos ministros, caso tenham dúvidas sobre o que consta nos autos, a utilização dos softwares de busca, disponíveis nos computadores em suas bancadas, para acessar as petições que compõem os autos. Contudo, em casos como a AP 470, devido ao tamanho do processo, é quase impossível rastrear os documentos. Daí a relevância da figura do revisor, que após uma nova leitura do processo garante que nada de "relevante" para a decisão ficou de fora da análise dos ministros.

Entre os ministros do tribunal, ainda que haja divergências, operam redes de confiança, necessárias ao funcionamento do STF. Se imaginarmos que todos os gabinetes precisariam analisar todos os processos e todas as etapas do processamento, a administração processual se tornaria impraticável.

O trecho do debate selecionado aponta para outra questão que nesse julgamento ganhou maior relevo, mas que aparece eventualmente nos debates da corte. Diz respeito à "imparcialidade do juiz". Conforme disse o ministro relator, teria ele sido acusado de ser parcial porque seu voto foi coincidente com os argumentos da denúncia. $\mathrm{Na}$ realidade, as coincidências dos votos ou com a defesa ou com a acusação sempre existirão. No entanto, e já apontei isso no capítulo anterior, para que uma decisão seja "imparcial" - ainda que eu não tenha clareza do que exatamente isso significa - em relação às partes, a progressão dos argumentos no decorrer do julgamento é quase uma condição. Vou tentar deixar isso mais claro: ainda que um ministro concorde com os argumentos apresentados por uma das partes, esses 
argumentos são, ao longo do julgamento, ressignificados, testados, rearticulados. A transformação do argumento das partes no argumento do juiz exige essa progressão. Nesse sentido, argumenta Latour (2010):

A progressiva articulação do caso, desde o escritório do advogado até sua exibição no julgamento, consiste em fazer o caso falar mais e mais como a lei, para que se tenha cada vez mais os argumentos ou os fundamentos mais bem revestidos e reagrupados. (p. 88)

Ao ressignificar os argumentos das partes, os ministros retiram deles uma interpretação guiada por um interesse particular, para transformá-los nos argumentos mais "corretos" ou "justos". Dessa forma, garantem que um voto não corresponde aos argumentos das partes, embora suas conclusões possam ser coincidentes.

Ultrapassadas as preliminares, o relator leu a primeira parte de seu voto de mérito, que foi distribuído aos demais ministros junto com os documentos que formaram seu convencimento. Concluiu seu voto - como sempre fazem os ministros - com a expressão "é como voto, Presidente", que indica que a palavra deve retornar ao presidente.

Seguiu-se então a proclamação do voto do revisor. Assim como fez o relator, o revisor distribuiu aos demais ministros seu voto e outra seleção de documentos extraídos dos autos. Os ministros têm a liberdade de selecionar documentos distintos para formar suas convicções. Cada um dos ministros deverá então demonstrar quais elementos das provas apresentadas o convenceram da veracidade ou não dos “acontecimentos". No entanto, os fatos com os quais a operação jurídica lida, como destacado por Thomas, são produzidos internamente na argumentação, ainda que essa argumentação tenha operado uma divisão entre questões de fato e questões de direito. Nos julgamentos que acompanhei, quando os advogados pediam a palavra para um esclarecimento de "fato", os ministros o alertavam de que se tratava de uma questão 
de direito. Exatamente porque não existem fatos em separado. Conforme o argumento de Nodari (2013):

Passar um ato ou fato da vida ao Direito é tipificá-lo. Nesse sentido, o tipo talvez seja o elemento gramatical básico da linguagem jurídica. Mas o que é exatamente um tipo? Quem melhor refletiu sobre a noção de "tipo" não foi um jurista, mas um sociólogo, Max Weber, sedimentando, com os chamados "tipos ideais", seu método em oposição ao método empírico-comparativista de Durkheim. Para Weber, os tipos puros ou ideais não poderiam ser encontrados "na realidade"; o que existia "de fato" era sempre um compósito, mais ou menos híbrido, de tipos que - e daí a natureza circular - se construíram a partir de elementos dispersos nesta "realidade" a que eram aplicados. Mas, como diz [Salvatore] Sata, na tipificação há uma redução, algo se perde - inclusive a linguagem comum. (idem $\mathrm{s} / \mathrm{p})$

Ademais, a própria natureza daquilo que pode ou não ser chamado de prova jurídica, e que permite afirmar se um evento aconteceu, está sempre em questão. Pottage (2012) destaca, a partir de Luhmann, que a técnica básica do direito está exatamente em decidir sobre a diferença entre o jurídico e o não jurídico. A qualidade dos enunciados legais então, conforme o autor, não está dada com antecedência, sendo sempre efeito de atribuição, estando sempre, portanto, em questão (p. 177).

A natureza das "provas" foi no julgamento da AP o grande motivo da divergência entre os ministros. Por um lado, alguns dos ministros defenderam não haver diferença entre provas extrajudiciais - aquelas produzidas em outros lugares que não sejam os tribunais - na denominada fase inquisitorial daquelas acompanhadas pelas partes e produzidas em território propriamente jurídico. Diversamente, outros ministros argumentaram que as provas judiciais, aquelas construídas sob o contraditório, teriam 
mais valor. Esse debate ainda envolve a distinção entre provas e indícios ou indícios como provas. Dito de outra forma, o debate central estava concentrado naquilo que pode produzir ou não uma condenação.

A verdade que emerge do processo e é extraída dele, não é a "verdade real". O que os ministros dizem buscar é a verdade processual, ou a "verdade suficiente", nos termos utilizados pelo ministro Fux durante do julgamento. O julgamento se volta assim a decidir não o que fizeram os denunciados, mas o que não deveriam ter feito.

\subsection{OS VOTOS DOS VOGAIS E OS CONVENCIMENTOS}

Quando relator e revisor terminam seus votos chegou então o momento dos votos dos ministros vogais. Os votos dos vogais, diferentemente dos votos anteriores, concentraram-se nos debates jurídicos sobre a natureza dos crimes e a valorização das provas. Por ordem decrescente de antiguidade, os ministros vão declarando seus votos, iniciando suas falas com qualificações aos votos já proferidos. As expressões "quero ressaltar o brilhantismo" ou "apesar do judicioso voto", que inauguram os votos dos vogais, não são apenas um protocolo, mas me parecem uma fórmula que garante aos votos, ainda que divergentes, posições de validade semelhantes. Os ministros também costumam cumprimentar o trabalho dos advogados que ocuparam a tribuna antes que comecem a leitura do voto.

Mesmo que ostentem inúmeras qualidades, a capacidade de síntese, salvo raros casos, não é uma característica que pode ser atribuída aos ministros. Até mesmo quando dizem que vão tecer brevíssimas considerações, certamente falarão por um longo tempo. Conforme os funcionários mais antigos do Tribunal e os ministros aposentados que entrevistei, o advento da transmissão dos julgamentos pela TV e pela web fez com que os ministros preparassem votos pensando no público que assiste às sessões. Existiria assim um diálogo implícito com os telespectadores, que demandaria votos mais elaborados dos ministros. Penso que nos casos com maior repercussão parece mesmo existir esse esforço em demonstrar os argumentos não apenas para os ministros, mas também para o público. Durante o curso do julgamento da AP 470, algumas vezes, quando um ministro concluía seu voto dizendo que julgava procedente 
ou improcedente a ação, o presidente do Tribunal repetia a conclusão do voto alterando os termos da conclusão.

\author{
Ministro A - Com essas considerações dou provimento aos \\ embargos.
}

Ministro Presidente - Vossa Excelência absolve todos os réus. Absolve todos.

Ministro A - Eu julgo procedentes os embargos.

Existe ainda outra dimensão da leitura de votos longos. Uma delas é que mesmo que as conclusões dos votos possam ser as mesmas, os fundamentos nem sempre são; assim, seria preciso expor quais fundamentos sustentam o que se está a decidir. Esse debate e essa divergência são muito sutis; demorei algum tempo até perceber que o "acompanho o relator" ou o "acompanho a divergência" - expressões utilizadas pelos ministros vogais para se alinhar aos votos já proferidos - ocultam fundamentos que não são iguais e podem ser até mesmo contrários (esclarecerei esse ponto do decorrer do texto). Ainda assim, o relator deve dizer ao final de seu voto quem acompanha, mesmo que, de fato, possa estar acompanhando apenas a conclusão. A autoria da tese jurídica sustentada e "acompanhada" é considerada pelos ministros no plenário como "voto condutor". A seguir, um trecho do julgamento:

Ministro A - Quero aqui acompanhar o voto da ministra Rosa Weber, que nesse ponto não sufragava a tese do ministro relator.

Ministro B- Pela ordem, eminente ministro Gilmar, peço licença. Primeiro, quero elogiar o voto de Sua Excelência, mas no caso de segundo peculato fui eu o primeiro a divergir. O próprio ministro 
Peluso também, data vênia, atribuiu a primeira divergência à ministra Rosa, mas peço escusas por entender...

Ministro A - Eu peço todas as desculpas, esse julgamento vai se alongando tanto que nos vamos perdendo. A memória vai se tornando mais e mais imprecisa. Peço todas as escusas. Mas é que ficou na memória o voto da ministra Rosa, que foi de segunda-feira.

Ministro B - Eu creio que ela explicitou melhor do que eu.

Ministro A - Não, nada disso; é que Vossa Excelência proferiu o voto já faz alguns dias.

Ministro $\mathrm{C}$ - Eu quero pedir escusas, mas eu acompanhei a ministra Rosa, sim. Porque a ministra Rosa absolveu por insuficiência de provas, e o revisor entendeu que não havia crime.

Ministro D - Se foi por insuficiência de provas, eu fui o primeiro a votar.

Outro aspecto da leitura dos votos pelos ministros vogais está na possibilidade de o "voto condutor" ser transformado em jurisprudência. Quanto mais completos os votos, mais "judiciosos", mais "substanciosos" ou até mesmo mais "bonitos", maior a possibilidade de o voto passar a ser repetido como precedente. Lembrando, como já destaquei no capítulo anterior, que a citação dos precedentes, quando não apenas numérica, seleciona trechos dos votos individuais proferidos em julgamentos anteriores como paradigmas da nova decisão. Ainda que se espere que os votos do relator ou do revisor sejam os mais completos e os mais "judiciosos", não serão necessariamente seus votos que se tornarão o paradigma da decisão tomada, nem mesmo o paradigma de novas decisões.

Por conta disso, ao se ler um voto escrito ou solicitar sua juntada aos autos, o que se espera é fazer parte desse conjunto de votos que dá origem à jurisprudência e que será 
inúmeras vezes repetido. A ideia de contribuir para a jurisprudência explicitou-se inúmeras vezes durante as entrevistas realizadas em campo. Quando se referiam aos ministros que mais "fizeram diferença", os ministros ou os servidores sempre citavam os ministros que aparecem mais nos julgamentos, ou seja, os ministros cujos votos são citados com frequência. Quando os ministros se aposentam, o Tribunal organiza um livro com os votos mais "importantes" - aqueles que contribuíram para formação da jurisprudência. Ressalto aqui um trecho do pronunciamento do ministro decano, por ocasião da aposentadoria de um dos ministros da corte. Ao enfocar a trajetória profissional do magistrado, o decano fez o seguinte comentário:

Apenas lamento que o legislador constituinte de 1988 não tenha sido tão sábio quanto foi o primeiro legislador constituinte republicano, que ao promulgar a Constituição de 1891 nem sequer estabeleceu limite etário para efeito de aposentadoria compulsória. Mas os grandes juízes do Supremo Tribunal Federal não partem jamais, eles permanecem eternos na memória e na história deste Tribunal.

Não todos os juízes são grandes, nem todos não partem jamais. Alguns dos ministros ficam esquecidos nos arquivos do tribunal e nas fotografias das composições anteriores. Contudo, aqueles com os votos "memoráveis" serão sempre lembrados, citados e homenageados. Em certa medida, faz sentido a ideia de que ser ministro não é apenas um cargo, mas um título que não se perde com a aposentadoria, porque os votos dos magistrados aposentados, ainda que sejam votos vencidos, continuam circulando nas decisões posteriores.

Ressalto ainda o papel estratégico do uso dos precedentes durante o julgamento. Entre os julgados selecionados para compor os votos, os ministros por vezes citam trechos de votos proferidos por ministros que estão no plenário. Caso o ministro citado para fundamentar um entendimento apresente no julgamento entendimento divergente, ele irá se pronunciar sobre o que "quis dizer" no voto citado, ou ainda pode argumentar 
que o caso não tratava da "mesma coisa". A divergência sobre o sentido compele o ministro citado a esclarecer durante seu voto a dúvida sobre o seu entendimento.

Trecho do voto anterior do Ministro A - Notei com muita recorrência aqui nesse julgado o "não tem provas contra mim". Aqui, aplicando subsidiariamente a regra do ônus da prova, o autor, Ministério Público, prova o fato constitutivo do seu direito e faz a prova que o convenceu em relação àquilo que aduzi. Cabe a contraprova àquele que se defende. A nossa jurisprudência é neste sentido: o álibi cabe a quem alega. Não basta dizer que não tem provas contra mim. Vou citar aqui precedentes emblemáticos do ministro... Eu não vou parafrasear o ministro Gilmar Mendes, que diz que até as pedras entendem, mas qualquer pessoa jejuna em direito entende. $\mathrm{O}$ álibi enquanto elemento de defesa deve ser comprovado a quem dele aproveita, isso se deu pela boca do ministro Celso Mello nosso decano.

Ministro B - Senhor Presidente, com a devida vênia do Ministro Fux, a acusação - pelo menos no nosso sistema constitucional desde 1988 - é que tem que fazer prova. Não vamos inverter isso, pois muita gente lutou para que tivéssemos essa garantia constitucional. A defesa não é obrigada a comprovar as suas versões. É a acusação que tem que comprovar e trazer provas sobre o seu libelo acusatório. Isso é das maiores garantias que a humanidade alcançou, e penso ser necessário que esse Supremo Tribunal Federal as resguarde. Não estou dizendo aqui em relação ao caso concreto, com suas várias interpretações, mas como premissa. Estou rebatendo o que foi dito não em relação ao caso concreto, mas como premissa teórica constitucional.

Ministro decano- $\mathrm{O}$ processo impõe ao órgão acusador o ônus integral da prova, referente aos fatos constitutivos da ação criminal. 
Ao mesmo tempo, faculta ao acusado, que jamais necessita demonstrar sua inocência, o direito de defender-se e de questionar criticamente todos os elementos probatórios constantes nos autos.

Ainda existe a possibilidade, poucas vezes acionada, de que os ministros discutam os fundamentos dos casos tomados como precedentes por algum ministro para “desautorizar” seu uso. Não é comum que isso aconteça porque poucos ministros apresentam a jurisprudência a partir de uma análise muito rigorosa sobre a lógica da decisão anterior. O precedente como dispositivo, no sentido de Latour (2010), não precisa ser aberto, evidenciando as redes e as disputas nele contidas, mas apenas mencionado e replicado. Normalmente, os ministros apenas discutem os precedentes do tribunal quando pretendem revertê-lo, tentando demonstrar a "fragilidade" do entendimento antes firmado ou sua inadequação diante de novas possibilidades.

Caso um precedente seja citado por algum ministro, os demais podem encontrar o conteúdo do dispositivo decisório no banco de dados, gerando um debate acerca da forma como o precedente foi utilizado. Segue um debate entre os ministros durante o julgamento da AP, para ilustrar o argumento:

Ministro A - Fui verificar a jurisprudência do tribunal nessa matéria, para saber se havia precedentes relevantes, e o que se vai verificar é a existência de inúmeros pronunciamentos do Supremo Tribunal Federal inequivocamente reconhecendo a subsistência dos embargos infringentes (essa era a questão em debate) muito depois da Lei 8.038, que seria a lei que teria revogado os embargos infringentes. Vou reproduzir algumas poucas passagens de acórdãos. Começo por um precedente do ministro Moreira Alves (...). 
Ministro B - Esses trechos citados por Vossa Excelência não seriam mero obter dicta (parte dos votos que seria dispensável para a decisão do caso concreto). São acórdãos da lavra desse plenário?

Ministro A - Eu refleti sobre essa questão.

Ministro B- Vossa Excelência tem como verificar. Consta da ementa de algum acórdão?

Ministro C- Em situação concreta que nós apreciamos não estava em jogo, então não houve decisão a respeito.

Ministro $\mathrm{A}-\mathrm{Eu}$ refleti sobre essa questão, e verdadeiramente as referências, no mais das vezes, foram feitas em obter dicta ou na motivação da decisão. Mas, claramente, na construção do seu argumento, todos esses ministros consideraram que o artigo regimental 333 estava em vigor. Portanto, eu não estou afirmando que se formou coisa julgada material em relação à subsistência. $\mathrm{O}$ que eu estou afirmando é que todos esses ministros que eu estou citando e outros tantos que integram o plenário, ao argumentarem sobre os embargos infringentes em outras situação, reconheceram de maneira inequívoca que eles continuavam vigentes.

Ministro C- Vossa Excelência admite que não há precedentes?

Ministro $\mathrm{A}-\mathrm{Eu}$ admito que não há um dispositivo de acórdão específico sobre a matéria.

Ministro B- Então não há precedentes. O que há são frases esparsas encontráveis em votos.

Ministro C- Precedente pressupõe dispositivo, não fundamentação estranha ao que está sendo julgado. 
Ministro B- Isso não é precedente. Precedente é exatamente isso que falou o ministro Marco Aurélio.

Ministro A- Vossa Excelência afirmou que existem inúmeros precedentes, e não há.

Ministro decano - Todos esses fundamentos, ainda que não façam, e não fazem, coisa julgada, mostram-se argumentos indissociáveis essenciais à própria exposição do pensamento revelado no voto desses juízes.

Entrevistei o ministro aposentado Sepúlveda ${ }^{44}$ Pertence no curso do julgamento da ação. Durante a entrevista, contou-me que estava acompanhando as transmissões dos julgamento, tendo ouvido diversas vezes trechos de um de seus votos sendo citados pelos ministros. Quando perguntei se ele achava que seus fundamentos poderiam sustentar os votos proferidos, ele riu. Sabia ele, bem mais do que eu naquele momento, que não faz sentido no direito reivindicar um sentido ao seu voto, quando ele já tem certa autonomia que independe das intenções do ministro.

Ainda durante o julgamento da Ação Penal 470, esteve no Brasil o jurista alemão Claus Roxin, autor da conhecida teoria do domínio do fato, amplamente evocada pelos ministros da corte como fundamentação para condenar um dos réus, quando supostamente não haveria provas materiais que autorizassem sua condenação. $O$ alemão, em entrevista ao jornal Folha de São Paulo, afirmou não ser possível usar a teoria para fundamentar a condenação de um acusado supondo sua participação apenas pelo fato de sua posição hierárquica. A entrevista foi entendida pelos advogados da defesa como uma desautorização ao uso da teoria feito pelos ministros

\footnotetext{
${ }^{44}$ Entrevista realizada outubro de 2012, no escritório de advocacia do ministro.
} 
do STF. No entanto, não estão previstas autorização para uso de determinada doutrina, nem se declaram juízos de um processo que não se conhece.

Quando se substitui o "mundo pelos autos" (Fernandes, 2010), impõe-se uma restrição a qualquer tipo de avaliação que possa ser realizada por aqueles que não fazem parte do processo, ainda que de certa forma façam, porque estão ali presentes. Quando algum jurista, seja ele advogado ou magistrado, emite qualquer opinião acerca de um processo no STF, sempre falam "em tese", já que desconhecem a realidade do processo julgado. Não é possível afirmar, sem que se conheçam os autos, se existem ou não existem provas.

Depois de falarem por algum tempo, os ministros concluem seu voto pela improcedência ou pela procedência da ação, com base em determinado artigo da lei. Essa frase será anotada pelo presidente para que conste na ata que será lida no dia seguinte.

\subsection{OS VENCIDOS E OS VENCEDORES}

Os debates e as disputas de entendimento entre os ministros acontecem em meio às interrupções - quando um ministro interrompe o voto de um colega para divergir de seu posicionamento, apontando questões que poderiam suscitar dúvidas sobre o voto que está sendo proferido. Os debates entre os ministros são acompanhados pelo seu corpo de assessores, através de televisores instalados nos gabinetes. Existe também um sistema de intranet que permite conversas entre os ministros e os integrantes do gabinete. Melo e Souza (2008) chama atenção para o papel dos assessores nos debates do plenário:

Todo bom assessor deve saber quando o processo que fez entra em pauta. Ele se prepara para prestar esclarecimentos ao ministro durante a sessão ou para ajudá-lo no caso de um debate oral com outro ministro. (p. 12) 
Interromper o pronunciamento de um ministro é muito comum em julgamentos, como uma tentativa de ponderar sobre alguma questão antes que se determine o voto com a expressão "É como voto, Presidente". No entanto, as interrupções costumam acontecer apenas entre os ministros mais antigos; os mais novos, poucas vezes se pronunciam durante a fala de um colega, embora durante suas exposições sejam recorrentemente interrompidos.

Ainda no capítulo anterior destaquei a tendência de os ministros mais novos na corte acompanharem a jurisprudência do Tribunal até que possam propor algumas flexibilizações e mudanças. Assim, costumam alinhar-se à corrente majoritária na votação e raramente inauguram a divergência, como se fosse necessário um tempo de experiência para aprender como as coisas funcionam, até que possam travar um debate com os demais ministros. Como esclarece o ministro Luís Fux:

Quando um ministro chega a um colegiado, a tendência é acompanhar a jurisprudência consolidada, que normalmente está nos votos majoritários. Você pode eventualmente ressaltar um ponto de vista, mas a tendência é acompanhar. Você não pode chegar a um colegiado tentando mudar tudo. Eu aprendi que o convívio no colegiado é $\operatorname{assim}^{45}$.

No caso da AP 470, por existir um revisor no processo que votava em seguida ao voto do relator, as divergências eram sempre abertas por ele, deixando os ministros mais novos em posição mais confortável para acompanhar o relator ou o revisor. Já na fase de recursos a figura do revisor deixou de existir, no mesmo momento em que dois novos ministros passaram a compor o colegiado. Coube então ao ministro recém-

\footnotetext{
${ }^{45}$ Entrevista realizada em 05/06/2012. STF
} 
chegado a ingrata posição de votar por primeiro, logo depois do voto do relator. $\mathrm{O}$ "desconforto" de votar por primeiro foi potencializado pela tensão entre os ministros durante todo o julgamento, que havia provocado embates acalorados entre relator e revisor. Em sua primeira intervenção no caso, um dos ministros recém-chegados afirmou:

As circunstâncias operacionais do Tribunal me fazem ser o primeiro a votar depois do relator, de modo que cumprirei, aplicadamente, resignadamente, meu papel de ser o primeiro a votar. Mas não havendo participado do julgamento, ouvirei com atenção os debates, e deixo logo consignado que estarei pronto para reajustar o meu voto se o Tribunal optar por reabrir a discussão de alguns temas.

A posição de autocontenção, esperada, foi levada em conta na primeira participação como ministro. Poucas sessões depois, os ministros mais novos se insurgiram, deixando de lado a contenção de seus posicionamentos para abrirem a divergência em relação ao voto do relator. A insurgência se deu exatamente na votação dos recursos que poderiam alterar a decisão. Não são todos os recursos que permitem reanalisar o caso julgado. A posição dos ministros recém-chegados não passou impune às observações de alguns dos ministros mais antigos:

Ministro A - Dou provimento ao recurso para declarar extinta a punibilidade. Adianto que caso fosse avançar para o mérito propriamente dito, meu voto estaria alinhado aos fundamentos sustentados pela ministra Rosa Weber. Concluiria assim que a hipótese foi de coautoria, e não de quadrilha. Fontes diversas divulgam o sentimento difuso de que qualquer agravamento das penas é bem-vindo e de que a imputação de quadrilha teria caráter exemplar e simbólico. É compreensível a indignação contra a histórica impunidade das classes dirigentes no Brasil, mas o discurso 
jurídico não se confunde com o discurso político, e no dia em que o fizer perderá sua autonomia e autoridade.

Ministro relator - Vossa Excelência chega aqui com o voto prontinho. Traz para o plenário do Supremo Tribunal Federal um discurso político para infirmar uma decisão tomada por um colegiado em um primeiro momento e confirmada em embargos de declaração. Isso me parece inapropriado, para não dizer outra coisa. A sua decisão não é técnica, é política.

Ministro A - Para mal dos pecados de Vossa Excelência, o meu voto vale tanto como o de Vossa Excelência. O esforço para depreciar quem pensa diferente, com todo respeito, é um déficit civilizatório.

Ministro $\mathrm{C}$ - Vejo que o novato parte para a crítica ao próprio colegiado, como partiu em votos anteriores, no que chegou a apontar que se estivesse a julgar não decidiria da forma que nós decidimos. Não respondi a Vossa Excelência porque achei que não era bom para a instituição a autofagia.

Ministro A - Eu discuto teses jurídicas, o resto considero irrelevante. Eu respeitei a decisão do Tribunal.

Ainda que expusessem um posicionamento divergente da maioria formada até então, os ministros "novatos" sabiam que a "conjuntura" do Tribunal era favorável ao entendimento esposado, ou seja, ainda que ficassem vencidos, o entendimento teria o respaldo de outros ministros. No caso concreto, os ministros não apenas encontraram respaldo, como compuseram uma nova corrente majoritária.

A partir das entrevistas realizadas com os ministros da corte, é possível afirmar que existe um desconforto de grande parte dos juízes em constar na posição vencida no colegiado, emitindo voto isolado, ou seja, não acompanhado por nenhum dos outros ministros. Conforme me disse o ministro Luís Roberto Barroso, alguns ministros, 
quando percebem a tendência do colegiado, podem mudar seu voto, tendo em vista que ficar vencido seria um ônus que, a depender do caso, "não valeria a pena". Uma decisão preferida por um plenário dividido deixaria sempre alguma questão em aberto, como se perdesse um pouco de sua eficácia.

Segue outro trecho da entrevista com o ministro Fux:

Às vezes eu fico vencido e fico satisfeito com que eu propus; mas eu não tenho por hábito ficar vencido. Quando fico vencido não me abalo, mas não tenho por hábito, não. O ministro Marco Aurélio pode falar melhor sobre isso. Ele acha que a beleza do colegiado é o voto vencido. Um voto vencido isolado é ruim, não tem beleza nenhum. Um voto vencido é ir contra o voto da maioria e depois ter que submeter ao colegiado. Tem que saber viver em colegiado; se o melhor para o país o colegiado acha que é aquilo, vamos embora, vamos adotar a posição ${ }^{46}$.

A referência ao ministro Marco Aurélio se dá porque ele tem por hábito ficar vencido, e em grande parte das vezes fica vencido sozinho. Essa posição não gera ao ministro nenhum desconforto; ao contrário, ele prefere deliberadamente sustentar uma posição minoritária, tendo em vista o valor dos votos vencidos. Em suas palavras:

Primeiro, não disputo coisa alguma; o que eu sempre faço questão é de revelar as razões do meu voto. Se eu pudesse dar um peso a um acórdão unânime e um acórdão por maioria, eu daria um peso maior a um acórdão por maioria, porque estaria estampada a certeza de que

\footnotetext{
${ }^{46}$ Entrevista realizada em 05/06/2012. STF
} 
duas vertentes foram discutidas. Eu sempre procedi assim. Só faço questão que se consigne como eu votei. Também não levanto o dedo para divergir querendo apenas aparecer como senhor de uma ideia diversa daquela revelada pelo consenso. Eu atuo com a minha responsabilidade ${ }^{47}$.

Disputar posição não é o modo de agir de todos os ministros. Conforme algumas entrevistas e as observações dos julgamentos existem no plenário alguns ministros considerados como lideranças. São aqueles que falam mais e falam sempre. Às vezes levantam a voz, expondo seus argumentos de modo mais enfático; têm a capacidade de "falar sem serem interrompidos" (Melo Souza: 2012, p. 112), embora sejam eles a interromper os demais ministros quando estes estão proferindo seus votos.

Acompanhei, durante o trabalho de campo, a entrada de três novos ministros, e conversando com alguns funcionários do Tribunal, com os quais mantinha contato frequente, havia sempre entre eles uma expectativa de como se comportaria o novo ministro diante dos ministros mais antigos. Um deles, certa vez me disse:

Acho que esse ministro novo vai ser importante, não vai se impressionar com quem levanta a voz no plenário. Se determinado ministro conhece direito alemão, se sabe muito, esse novo que vem aí tem até mais conhecimento.

Desse modo, a "demonstração de domínio da competência judicial” (ibidem, p. 113) é um diferencial que coloca alguns dos ministros em posição considerada como de liderança e autoridade. Contudo, como demonstra Mello e Souza (2012), a autoridade

\footnotetext{
${ }^{47}$ Entrevista realizada em 13/09/12
} 
dos ministros pode variar a cada processo, dependendo da matéria em julgamento. Ainda que alguns votos sejam considerados mais relevantes do que outros e que alguns ministros tenham maior capacidade de influir nos votos dos demais, não é possível localizar alianças no plenário. O que parece existir são alinhamentos de acordo com os processos. No sentido que não existe um direito, as áreas ou subdivisões do conhecimento jurídico, implicam posições diferentes dos ministros. Um ministro considerado liberal em seus votos no direito penal pode ser conservador em outras áreas do direito por exemplo.

A entrada de novos ministros com a aposentadoria de outros muda também configuração do plenário. Os demais ministros trocam de lugar de modo a ajustar as posições de acordo com a antiguidade, ou seja, quando um ministro deixa o tribunal, os ministros mais novos que lá estão vão se tornando mais antigos, saltando para as poltronas mais próximas ao presidente. Ao ministro mais novo está reservada a última poltrona à esquerda do presidente, próxima a tribuna dos advogados. Essa mudança por vezes altera os vizinhos imediatos dos ministros, aqueles que se sentam um ao lado do outro. Ao assistir a sessão plenária, é possível observar que os ministros sentados próximos, em diversos momentos dos julgamentos, conversam entre si, trocam percepções das discussões do plenário, uma conversa que só pode ser ouvida, caso os ministros se esqueçam de afastar o microfone que está a sua frente. Algumas vezes, os próprios ministros expõem aos colegas esses debates particulares empreendidos com os colegas mais próximos como condutores de novos entendimentos.

Quem não muda de posição e tampouco tem uma autoridade flutuante é o decano da corte. O ministro que na época da pesquisa era o mais antigo dos ministros atua no STF há mais de vinte anos, contudo, quando o ouvimos, parece que sempre esteve lá, sentado na última cadeira do pleno. Ao assumir a palavra para declarar seu voto, os assistentes do plenário procuram saber com o assistente do ministro decano quantas páginas terá o voto. Costumam ser longos. Cinquenta páginas são consideradas pelos funcionários um voto curto para os parâmetros do decano. São longos, porque parece ser parte de seu papel historicizar as decisões, conferir aos debates e aos demais votos um "contexto". 
Ao ouvir o decano, ele parece saber de memória todos os julgamentos citados no plenário como precedentes. Sabe dizer quais foram os debates que levaram a determinada decisão, e até mesmo o placar de cada caso julgado. Quando o decano fala, seja na sua vez, seja quando pede a palavra no meio de um debate, é sempre ouvido; os demais ministros parecem até mesmo se sentir honrados quando o ele pede um aparte em suas falas. Além disso, cabe a ele contemporizar, quando os debates vão se tornando cada vez mais acirrados.

Não existem no Tribunal espaços de discussão entre os ministros que não sejam os espaços de julgamento, nas turmas ou no plenário. A rigor, os ministros não discutem seus votos com os colegas antes dos julgamentos, apenas trocam impressões com seus pares enquanto esperam, no salão branco, a entrada no plenário. Seria o espaço do julgamento o lugar privilegiado para o debate, ainda que se espere dos magistrados comedimento na argumentação e na contra-argumentação.

A tensão entre os ministros e a troca de acusações acontece quando a presunção de legitimidade dos votos proferidos deixa de operar, abrindo as portas para um enfrentamento não apenas acerca dos princípios jurídicos que fundamentam os votos, mas também e, sobretudo sobre as possíveis intenções que dirigem as ações. No julgamento da AP 470 ocorreram vários desses enfrentamentos, potencializados pela presença dos veículos de comunicação.

Segundo Sepúlveda Pertence, as situações de tensão no Tribunal que acabam em xingamentos e desqualificações ferem a "credibilidade" do STF. Em suas palavras:

Hoje, as pessoas assistem a esse mensalão na expectativa de mais uma rabanada. O tom das discussões no plenário se transmitiu. A mídia, por exemplo, perdeu toda cerimônia. Já não se fala mais o 
ministro fulano de tal; eles falam o Joaquim, o Toffoli. Não existe mais cerimônia ${ }^{48}$.

O ritual do julgamento seria também uma forma de preservação do Tribunal e de sua forma de funcionamento que ultrapassaria seus ministros e suas idiossincrasias. $\mathrm{O}$ comedimento e a urbanidade no trato garantiriam a "credibilidade" do Tribunal, com a certeza de que ali não estão pessoas comuns, mas juízes. Normalmente, quando os debates são mais acalorados, os termos ou expressões usados pelos ministros são retirados do acórdão. Assim como podem ser retirados outros pronunciamentos que não apenas aqueles proferidos no calor do debate. De certa forma, os ministros admitem que nem tudo que falam deve ser levado em consideração, e que as falas improvisadas nem sempre correspondem exatamente ao que pensam. E não estando no acórdão, elas desaparecem do universo jurídico dos tribunais e dos processos, já que não podem ser citadas por não constarem no dispositivo decisório.

\subsection{UM ESTADO DAS COISAS}

Quando o tempo de recorrer de uma decisão acaba, o SEJ declara o trânsito em julgado de um processo e a decisão do caso faz o que se denomina coisa julgada. Isso significa que a decisão se torna indiscutível. O jurista Pontes de Miranda afirmou que a coisa julgada "faz do branco preto; origina e cria as coisas; transforma o quadrado em redondo; altera os laços de sangue e transforma o falso em verdadeiro".

A coisa julgada, ou res judicata, expressão do direito romano, tornaria definitiva uma decisão apenas para um processo, o que significa que as mesmas pessoas, no mesmo tipo

\footnotetext{
${ }^{48}$ Entrevista realizada outubro de 2012 , no escritório de advocacia do ministro.
} 
de processo, com o mesmo objeto, não podem reivindicar uma nova análise ou uma nova decisão. O que não quer dizer que o objeto jurídico do processo seja indiscutível, ao contrário é possibilidade da mudança que movimenta os processos e as causas.

Quando se faz coisa julgada o tribunal toma então por verdade sua decisão, seguindo a fórmula romana res judicatta pro veritate habetur (a coisa julgada é tida como verdade). O que não significa que seja verdade, tão pouco que não seja. A verdade processual solidifica uma verdade provável, possível e passível de ser extraída nos documentos. pessoas ele ou ela e as de direitos e obrigações arquetípicas portadores naturais?

Como Thomas (1995) chama atenção, para coisa julgada como efeito do tempo; só se decide uma questão, porque não se pode discuti-la eternamente, pelo menos em um processo específico. E nesse sentido, as temporalidades que marcam o "fazer processo", seriam as garantias que a questão em debate nos processos cumpriram suas trajetórias qualificadas, que os objetos dos processos foram desgastados ao ponto de rasgar as capas dos autos, que todos os documentos que poderiam fazer diferença foram anexados, numerados e carimbados. 


\section{CONSIDERAÇÕES FINAIS}

\section{É tempo de processo}

A passagem ocidental do tempo nada mais é do que uma forma particular de historicidade [...] A antropologia está ai para lembrar que tal passagem pode ser interpretada de diferentes formas [...] Vivemos a sensação de uma flecha irreversivel do tempo. Como observava Nietzsche, os modernos têm a doença da história. Querem datar tudo, porque pensam terem rompido definitivamente com o passado [...] Mas o passado permanece ou mesmo retorna. (LATOUR, 1993)

Assim como nos processos, o final de uma tese, ou desta tese, é também efeito do tempo. Não obstante a tese seja resultado de uma extensa reflexão, aprendi com os ministros e com os funcionários do tribunal que nada é tão definitivo que não possa sofrer inflexões ao longo do tempo. O resultado é então como uma decisão: um estado das coisas.

O que tentei demonstrar ao longo dos capítulos é que o mobiliário do universo do tribunal é maior do que apenas seus ministros e o conteúdo de suas decisões. A relação entre a potência da Constituição e as formas como ela é tecnicamente interpretada pelos ministros envolve movimentos e fluxos mais ou menos coerentes entre uma expectativa de justiça e as possibilidades do direito. Dessas cascatas de relações entre meios e fins já falava Riles (2011). 
A relação dos ministros com a Constituição e as formas de torná-la real, por meio das decisões judiciais, retomam do processo constituinte a ideia de "vontade popular", amalgamada no texto constitucional, que amplia os direitos individuais e coletivos. Esses direitos, transformados em processos, chegam ao tribunal e passam por diversas intervenções, que anexam uma sequência de coisas/documentos/procedimentos repletos de disputas, formas, timbres, carimbos, assinaturas e relações. As decisões são, assim, resultados desses fluxos e de suas temporalidades. Da gerência dos processos e das relações entre os setores, os processos organizam, associam e relacionam pessoas (Hull, 2012a: 134).

No tribunal é possível afirmar que, ao mesmo tempo em que apenas os ministros decidem, todo mundo toma decisões que irão compor "a decisão", pois, quem trabalha para a decisão também a constitui. A diferença entre técnica e criatividade apresentada nas falas dos servidores remete às diferenças entre processos convencionais e inventivos, descritos por Roy Wagner (2004), como formas de tornar inteligíveis e reconhecíveis as coisas. Nesse sentido, as decisões são sempre do tribunal, não como ente abstrato, mas como um composto de setores distintos que fazem decisão fazendo processos.

Pensando nas decisões, proponho então uma breve reflexão sobre o tempo, ou as temporalidades do tribunal e dos processos. Tendo em vista que uma decisão que se toma hoje - no presente - é também uma decisão que se toma no futuro, não apenas porque algumas se tornam modelos repetidos, mas, sobretudo, porque uma decisão se inspira em decisões anteriores.

As práticas temporais ou temporalizantes, segundo Latour (1993), seriam uma maneira de conectar entidades, armazená-las ou colocá-las em uma forma mais ou menos permanente. Conforme o autor, é perfeitamente possível e até mesmo normal conectar elementos de diferentes épocas e misturá-los. Desse modo, as decisões emergem da mistura entre o que era antes e o que deverá ser. Como sugeriu Pottage (2004), "estamos em ambas às extremidades do contínuo", como se tivéssemos, ao mesmo tempo, "mais tradição e mais modernidade" (Strathern apud Pottage, p. 9). A dinâmica dos votos vencidos funciona aqui como metáfora. Votos vencidos proferidos em um passado mais ou menos recente podem carregar as interpretações "avançadas" 
que aos poucos vão sendo incorporadas pelo tribunal. Nesse sentido, acompanho o argumento de Pottage (idem), segundo o qual o esquema clássico de divisão entre o passado e futuro pode ser incorporado nas categorias da experiência de tal forma que o momento atual a partir do qual o mundo é observado se apresenta em sucessões modais presentes como presente do passado, presente real e futuro do presente. O dilema nas transformações dessas divisões, os esquemas baseados em formulários baseados por sua vez em distinções surgem do reconhecimento de que esses esquemas lineares tornaram-se "desincorporados", na medida em que o presente se torna uma referencia a um observador particular, ao invés de uma posição "incorporada" em uma sucessão linear.

No caso das decisões judiciais, emergem sempre situações de risco, observadas pelos ministros em cada caso. Por isso utilizam a expressão "tenho dificuldade". Exatamente porque se sabe que uma decisão no presente terá consequências que se tornarão aparentes apenas no futuro. A gerência desse "risco" é mais ou menos atenuada, na medida em que as decisões se ancoram em decisões já tomadas, em que significados e sentidos vão sendo criados assim uns a partir dos outros ou por meio dos outros (Wagner 1981), mas também se gerenciam os riscos com a política, com as estratégias de convencimento e com a dinâmica de segurar/liberar os processos. Essas relações entre o contínuo e descontinuo se relacionam com os espaços no tribunal e as formas estéticas que compõem os ambientes em que circulam pessoas e processos.

As reflexões sobre o tempo e as temporalidades não são novas para a antropologia. Alfred Gell (1992), por exemplo, diferenciou duas séries temporais: a série A, que diz respeito ao tempo objetivo, às cronologias e aos mapas temporais, e a série $\mathrm{B}$, que seria o tempo experimentado, o tempo dos fluxos e das ontologias. Coutin e Yngvesson (2008) chamam atenção para as noções de tempo no direito como algo que não exatamente passa, mas que explode justamente a noção de passagem do tempo, porquanto nada nunca acaba. Essas várias representações temporais criariam uma abertura para o conhecimento produzido através do direito (p. 5).

Retomando a ideia de que existe um novo tribunal, é possível pensar que esse novo só se tornou possível com a aposentadoria de um ministro considerado conservador. Ao 
mesmo tempo, esse ministro é ainda hoje autor dos votos mais citados, ou seja, a jurisprudência e os precedentes por ele consolidados ainda imperam no novo tribunal.

Certamente não imagino que apenas a saída de um dos ministros mais lembrados do STF seja causa suficiente para uma transformação do tribunal, mas que sua saída seja apontada como marco da mudança me parece um dado relevante. Na realidade, parece existir um tempo de maturação da própria Constituição e do campo legislativo que a regulamenta e que permitirá a experimentação de novos critérios hermenêuticos, novas formas e procedimentos, novos tipos de processos.

As temporalidades do tribunal estão relacionadas tanto aos prazos como a um tipo de duração dos processos, sendo atravessadas por outras temporalidades como o tempo dos ministros ou o tempo da jurisprudência. As "paisagens legais" são então marcadas por criações temporais distintas, que incidem sobre os processos e sobre as decisões.

Como já destaquei ao longo da tese, as causas que chegam ao tribunal são inscritas nas lógicas de circulação local, e vão ao longo de suas trajetórias formando objetos jurídicos que se desenvolvem a partir da conexão de camadas de textos e de documentos, assuntos, temas e precedentes. Os processos de extração de sentidos e as passagens dos textos pelos critérios mais ou menos definidos tornam explícitas as intenções e vontades das normas e da legislação que antes nem sequer eram aventadas. Ao mesmo tempo, os processos algumas vezes precisam aguardar a consolidação ou a inflexão de paradigmas para que possam sair da prateleira com destino ao plenário do STF. A solução de um caso, portanto, pode ser realizada apenas com a espera.

As temporalidades que marcam a evolução dos processos acumulam por um lado a segurança jurídica, no sentido que serão decididos a partir de réplicas do que já está consolidado, mas, por outro lado, também se nutrem da dúvida mantida durante o tempo do processamento de vários processos.

As despacificações e as mudanças de orientação são possíveis na lógica local a partir de destaques que indicam existirem questões que precisariam ser rediscutidas em momento apropriado ou em espaço apropriado. Os indicativos de mudanças ou de 
despacificações ficam então à espera dos tipos certos de processo para que os ministros possam apresentar seus entendimentos sem a necessidade de "acompanhar" o que já está consolidado.

A gerência das mudanças aparece também naquilo que chamei de política dos processos, assim como nas estratégias de convencimento entre os ministros durante os julgamentos plenários. Os processos, então, tornam-se objetos da política do tribunal e das manipulações temporais.

Retomo a primeira entrevista apresentada na introdução em que a funcionária me explicava que os processos são a vida do tribunal. Ao acompanhar o "fazer processo" e "carregar processo" tentei demostrar as formas possíveis de constituição do real que se faz através da transformação mais ou menos controlada, mais ou menos evidenciada nas diversas camadas de papéis. Não encontrei assim totalidades integradas num todo homogêneo, mas práticas de conhecimento diversas vezes organizadas pelo caos, pelo acumulo e pelas contingências concretas desses elementos todos. 


\section{REFERÊNCIAS BIBLIOGRÁFICAS}

Barrera, Leticia. "Files Circulation and the Forms of Legal Experts: Agency and Personhood in the Argentine Supreme Court". Journal of Legal Anthropology 1, no. 1: 3-24 170, 2008.

-. "Restoring Legality: Performativity, Transparency, and the Crafting of a new Institutionality". Paper presented at the American Anthropological Association Annual Meeting, San Francisco, U.S.A., November 19-23, 2008.

Beviláqua, C. Chimpanzés em Juízo: Pessoas, Coisas e Diferenças. Horizontes Antropológicos, Porto Alegre, ano 17, n. 35, p. 65-102, jan./jun, 2011.

. Etnografia do Estado: Algumas Questões Metodológicas e Éticas. In: Campos. No 3, Curitiba, 2003.

Biagioli, Mario. "Documents of Documents: Scientists' Names and Scientific Claims". In Documents: Artifacts of Modern Knowledge, edited by Annelise Riles, 127-157. Ann Arbor: The University of Michigan Press, 2006.

Bourdieu, Pierre. "From the King's House to the Reason of State". Constellations 11, no. $1,2004$.

-. "The Force of Law: Toward a Sociology of the Juridical Field". Hastings Law Review 38: 805-53., 1987.

BOLTANSKI, Luc. L'amour et la justice comme compétences: trois essais de sociologie de l'action. Paris: Ed. Métailié, 1990. 
Casey, Edward S. "How to Get from Space to Place in a Fairly Short Stretch of Time. Phenomenological Prolegomena". In Senses of Place, edited by Feld, Steven and Foucault, Michel. La Verdad y Las Formas jurídicas. 4a. Edición. Barcelona: Gedisa Editorial, 1995.

CARDOSO DE OLIVEIRA, Luis Roberto. (2002), Direito legal e insulto moral: Dilemas da cidadania no Brasil, Quebec e EUA. Rio de Janeiro, Relume Dumará.

Garapon, Antoine. Bien Juger. Essai Sur Le Rituel Judiciare. Paris: Editions Odile Jacob, 1997.

Geertz, Clifford. Local Knowledge, further Essays in Interpretive Anthropology. 2000 Edition. New York: Basic Books, 2000.

-. Negara: The Theatre State in Nineteenth-Century Bali. Princeton, N.J.: Princeton University Press, 1980.

—. The Interpretation of Cultures: Selected Essays. New York: Basic Books, 1973.

Hermitte, Marie-Angèle. "Le droit est un autre monde”. Enquête, 1998.

Hull, Matthew. Government of Paper: The Materiality of Bureaucracy in Urban Pakistan. Berkeley: University of California Press, 2012.

-. "Documents and Bureaucracy". Annual Review of Anthropology. 41:251-67, 2012.

Jacob, Marie-Andrée. "The Match of Relatedness: Bureaucracy, Legitimation and Kinship in Organ Transplants.". J.S.D. dissertation, Cornell University, 2006.

Jacob, Marie-Andreé and Annelise Riles. "The New Bureaucracies of Virtue: Introduction". The Political and Legal Anthropology Review 30, no. 2: 182-191, 2007. 
Jacob, Marie-Andrée. "Form-made Persons: Consent Forms as Consent's Blind Spot”. The Political and Legal Anthropology Review 30, no. 2: 249-268. , 2007.

-. "The Shared History: Unknotting Fictive Kinship and Legal Process". Law and Society Review 49 (forthcoming 2009), 2009.

Kelsen, H. Teoria pura do direito. São Paulo: Martins Fontes, 2003c. 427 ISBN 8533608365, 2003.

Koerner, Andrei e Freitas, Lígia Barros de. O Supremo na constituinte e a constituinte no Supremo. Lua Nova [online], 2013.

Latour, Bruno and Woolgar, Steven. Laboratory Life: The Construction of Scientific Facts. Princeton, NJ: Princeton University Press, 1986.

-. Laboratory Life: The Construction of Scientific Facts. Princeton, NJ: Princeton University Press, 1986.

Latour, Bruno. "Scientific Objects and Legal Objectivity". In Law, Anthropology and the Constitution of the Social: Making Persons and Things, edited by Alain Pottage \& Martha Mundy, 73-114. Cambridge: Cambridge University Press, 2004.

----. THE MAKING OF LAW: AN ETHNOGRAPHY OF THE CONSEIL 'ETAT Paris: La Découverte /Poche, 2010.

-. Pandora's Hope: Essays on the Reality of Science Studies. Cambridge, Mass.: Harvard University Press, 1999.

-. Reassembling the Social: An Introduction to Actor-Network-Theory. Oxford;New York: Oxford University Press, 2005.

Law, John e Mol, Annemarie. Complexities: Social Studies of Knowledge Practices. Duke University Press, 2002. 
-. Complexities: Social Studies of Knowledge Practices. Duke University Press, 2002.

Leach, James. "Modes of Creativity". In Transactions and Creations: Property Debates and the Stimulos of Melanesia, edited by Marilyn Strathern and Eric Hirsch, 152-175. New York, Oxford: Berghahn Books, 2004.

Lugones, Maria Gabriela. Obrando en autos, obrando en vidas: formas y fórmulas de protección judicial en los tribunales pre-vencionales de menores de Córdoba, Argentina, a comienzos del siglo XXI. 2012.

Luhmann, N. Sistemas sociales: lineamientos para una teoría general. Rubí (Barcelona): Anthropos; México: Universidad Iberoamericana; San- tafé de Bogotá: CEJA, Pontifícia Universidad Javeriana. 445 p, 1998.

Luhmann, Niklas. A sociological theory of law. London: Routledge and Kegan Paul, 1985.

—. Social systems. Stanford, Califórnia, Stanford University Press, 1995.

—. Sociologia do direito. Rio de Janeiro, Edições Tempo Brasileiro, v. I e II, 1983.

Negri, Antônio. O Poder Constituinte: ensaio sobre as alternativas da modernidade. DP\&A: Rio de Janeiro, 2002.

Nodari, Alexandre. Verbete Juridiquês. (2013)

http://culturaebarbarie.org/sopro/verbetes/juridiques.html\#.VBaM6khoHII

Niklas, Luhmann. A sociological theory of law. London: Routledge and Kegan Paul, 1985.

Onto, Gustavo. "Da irrelevância do mercado ao mercado relevante: economistas, teoria econômica e política antitruste no Brasil.". Dissertação de Mestrado 
apresentada na Escola de Administração de Empresas. São Paulo: Fundação Getúlio Vargas, 2009.

—. "Mercado Relevante: uma perspectiva etnográfica". IN: Compêndio de Direito da Concorrência: temas de fronteira (ed. Mendonça, Elvino). Editora Migalhas (no prelo)., 2014.

-. "Economic Regulation or the Ethnography of Attachments". IN: Latour, Bruno. An Inquiry into Modes of Existence. English version. Versão eletrônica. (http://www.modesofexistence.org/inquiry/?lang=en\#a=CONTRIB\&c[leading]=COM $\& \mathrm{c}[$ slave $]=$ TEXT\&i $[\mathrm{id}]=\% 23$ cont $-15235 \& \mathrm{i}[$ column $]=\mathrm{COM}), 2014$.

-. "The market as lived experience: On the knowledge of markets in antitrust analysis". in: Vibrant - Virtual Brazilian Anthropology, v. 11, n. 1. January to June 2014. Brasília, ABA. Available at http://www.vibrant.org.br/issues/v11n1/gustavoonto-the-market-as-lived-experience-on-the-knowledge-of-markets-in-antitrustanalysis/, 2014.

Pottage, Alain and Mundy, M. Law, anthropology, and the constitution of the social: making persons and things. Cambridge, UK: Cambridge University Press, 2004.

Pottage, Alain. "Law after Anthropology: Object and Technique in Roman Law". Theory Culture Society, 0(0) 1-20, published online 21, January, 2014.

-. "Persons and Things: An Ethnographic Analogy". Economy and Society 112, no. $138,2001$.

—. "The Materiality of What?". In Journal of Law and Society. Vol. 39 (1), March. Pp.167-183, 2012.

Reed, Adam. "Documents Unfolding". In Documents: Artifacts of Modern Knowledge, edited by Annelise Riles, 158-177. Ann Arbor: The University of Michigan Press, 2006. 
-. Papua New Guinea's Last Place: Experiences of Constraint in a Postcolonial Prison. New York-Oxford: Berghahn Books, 2004.

Riles, Annelise. "Cultural Conflicts". Law and Contemporary Problems 71 no. 3 (Summer) 273-308, 2008.

-. "Law as Object". In Law \& Empire in the Pacific, Fiji and Hawai'i, editado by Sally Engle Merry and Donald Brenneis, 187-212. Santa Fe, NM: School of American Research Press, 2003.

-. "The Anti-Network: Private Global Governance, Legal Knowledge, and the Legitimacy of the State". American Journal of Comparative Law 56, (Summer): 605$630,2008$.

-. "The Legal Fiction: Technical Hope at the Center of Capitalism". In Hope in the Economy, edited by Hirokazu Miyazaki and Richard Swedberg, 2009.

-. "[Deadlines]: Removing the Brackets on Politics in Bureaucratic and Anthropological Analysis”. In Documents: Artifacts of Modern Knowledge, edited by Annelise Riles. Ann Arbor: The University of Chicago Press, 2006.

-. "A New Agenda for the Cultural Study of Law: Taking on the Technicalities". Buffalo Law Review 53: 392-405, 2005.

-. "Comparative Law and Socio-Legal Studies". In The Oxford Handbook of Comparative Law, edited by Mathias Reinman and Reinhard Zimmerman, 776-813. Oxford: Oxford University Press, 2006.

-. "Introduction: In Response". In Documents: Artifacts of Modern Knowledge, edited by Annelise Riles, 1-38. Ann Arbor: The University of Michigan Press, 2006.

-. "Property as Legal Knowledge: Means and Ends". Journal of the Royal "Real Time: Unwinding Technocratic and Anthropological Knowledge." American Ethnologist 31, no. 3: 392-405. 186, 2004. 
-. "The Empty Place: Legal Formalities and the Cultural State". In The Place of Law, edited by Austin Sarat, Lawrence Douglas and Martha Merrill Umphrey, 43-73. Ann Arbor: The University of Michigan Press, 2003.

-. "The Legal Person: An Anthropological Approach to Corporate Debt". Paper presented at the Conference "Legal Knowledge and Anthropological Engagement" in honor of Professor Marilyn Strathern, Cambridge, U.K., October 3-4, 2008.

—. The Network Inside Out. Ann Arbor: The University of Michigan Press, 2001.

SAMUEL, Geoffrey. 2004 Epistemology and Comparative Law: contributions from the sciences and social sciences. In Epistemology and methodology of comparative law. M.v.Hoecke, ed. Pp. 35-77. Oxford : Hart Pub

Sarat, Austin, Lawrence Douglas and Martha Merrill Umphrey. "Where (Or what) is the Place of Law? An Introduction". In the Place of Law, edited by Austin Sarat, Lawrence Douglas and Martha Merrill Umphrey, 1-20. Ann Arbor: The University of Michigan Press, 2003.

Schmitt, Carl. Théologie politique. Paris: Gallimard, 1988.

Shannon, Jennifer. "Informed Consent: Documenting the Intersection of Bureaucratic Regulation and Ethnographic Practice". The Political and Legal Anthropology Review 30, no. 2: 229-248, 2007.

Strathern, Marilyn. "Introduction: New Accountabilities". In Audit Cultures: Anthropological Studies in Audit, Ethics and the Academy, edited by Marilyn Strathern, 1-18. London: Routledge, 2000.

- Property, Substance and Effect: Anthropological Essays on Persons and Things. London \& New Brunswick, NJ: The Athlone Press, 1999.

-. The Gender of the Gift: Problems with Women and Problems with Society in Melanesia. Berkeley: University of California Press, 1988. 
SCHUCH, Patrice. Práticas de Justiça: Uma Etnografia do "Campo de Atenção ao Adolescente Infrator" no Rio Grande do Sul, depois do Estatuto da Criança e do Adolescente. Tese de doutorado apresentada no Programa de Pós-Graduação em Antropologia Social. Porto Alegre: Universidade Federal do Rio Grande do Sul, 2005.

Tecnologias da não-violência e modernização da justiça no Brasil : O caso da justiça restaurativa

SCHRITZMEYER, Ana Lúcia Pastore. Controlando o poder de matar : uma leitura antropológica do Tribunal do Júri - ritual lúdico e teatralizado [online]. São Paulo : Faculdade de Filosofia, Letras e Ciências Humanas, Universidade de São Paulo, 2002. Tese de Doutorado em Antropologia Social

Teubner, G. Enterprise Corporatism: New Industrial Policy and the "Essence" of the Legal Person. The American Journal of Comparative Law. Vol. 36, No. 1 (Winter), pp. 130-155, 1987.

Thomas, Yan. Fictio Legis: L'empire de la fiction Romaine et ses limites Medievales. Droits 21:17-63, 1995.

—. "Présentation". Annales . 57e année, 6: 1425 - 1428, 2002.

Valverde, Mariana. "Jurisdiction and Scale: Legal 'Technicalities' as Resources for Theory". Social Legal Studies, June. Vol. 18, no. 2, 139-157, 2009.

-. "Theoretical and Methodological Issues in the Study of Legal Knowledge Practices". In Sarat, Douglas e Umphrey (eds.) How Law Knows. Stanford University Press, 2007.

Visman, Cornellia. Files: Law and Media Technology. Stanford, CA: Stanford University Press, 2008.

Wagner, Roy. An Anthropology of the Subject: Holographic worldview in New Guinea and its Meaning and Significance for the World of Anthropology. Berkeley: University of California Press, 2001. 
-. Symbols that Stand for Themselves. Chicago: University of Chicago Press, 1986.

- The Invention of Culture. Revised and Expanded Edition. Chicago: The University of Chicago Press, 1981.

Yablon, Charles M. "Forms". Cardozo Law Review 11:5: 1349-1353, 1990.

Yngvesson, Barbara and Coutin, Susan. "Backed by Papers: Undoing Persons, Histories, and Return". American Ethnologist 33, no. 2: 177-190, 2006.

-. "Technologies of knowledge production: law, ethnography, and the limits of explanation. Polar 31, 2008.

Yngvesson, Barbara. Virtuous Citizens, Disruptive Subjects: Order and Complaint in a New England Court. New York: Routledge, 1993. 


\section{ANEXO 1- BIOGRAFIA DOS MINISTROS ${ }^{49}$}

\section{Luiz Fux}

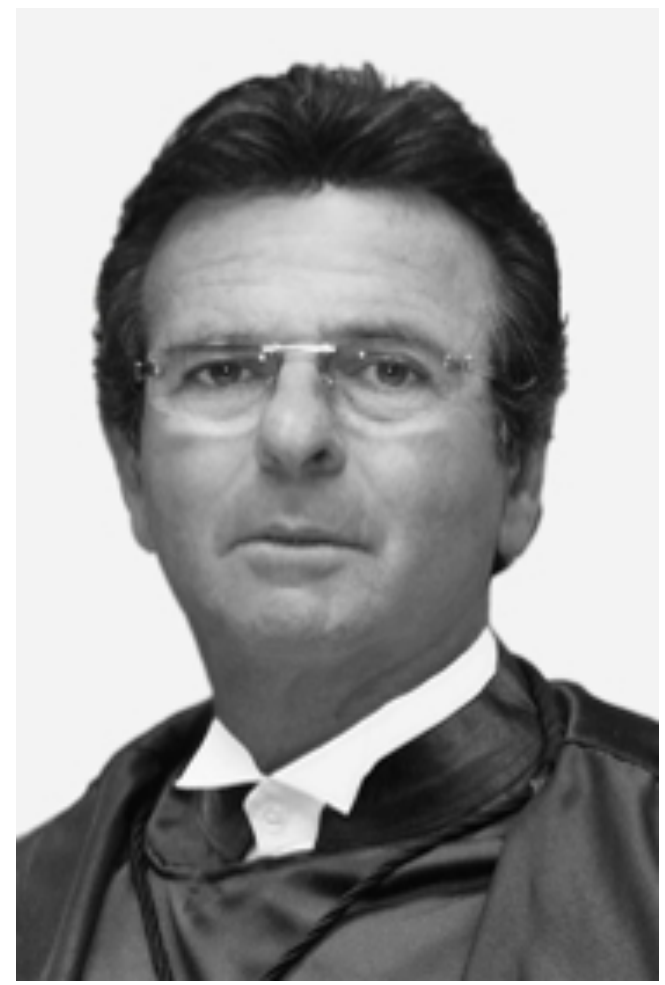

Luiz Fux nasceu em 26 de abril de 1953, no Rio de Janeiro. É filho de Mendel Wolf Fux e Lucy Fux, casado com Eliane Fux e tem dois filhos: Marianna e Rodrigo.

Possui graduação em Direito pela Universidade do Estado do Rio de Janeiro - UERJ (1976), ensino fundamental (primeiro-grau) pelo Colégio A. Liessin (1965), ensino médio (segundo-grau) pelo Colégio Pedro II (1968) e ensino médio (segundo-grau) pelo Colégio Hélio Alonso (1970).

Em 2009, obteve o título de Doutor em Direito Processual Civil pela Universidade Estadual do Rio de Janeiro - UERJ. Foi Professor titular de Processo Civil da Faculdade de Direito da Universidade do Estado do Rio de Janeiro - UERJ, aprovado em $1^{\circ}$ lugar em concurso em 1995. Foi Professor Livre-Docente em Processo Civil da Faculdade de Direito da Universidade do Estado do Rio de Janeiro - UERJ, aprovado em $1^{\circ}$ lugar em concurso em 1998.

Foi Professor Livre Docente de Processo Civil e Professor Titular de Processo Civil da Universidade do Estado do Rio de Janeiro - UERJ. Nível: Graduação, Mestrado e

\footnotetext{
${ }^{49}$ As pequenas biografias que apresento agora em anexo estão disponíveis na página do STF. www.stf.jus.br. Ficaram faltando alguns ministros que não tinham material disponível.
} 
Doutorado, 1977. Professor convidado da Universidade Católica de Petrópolis - UCP, 1988. Professor Convidado do Centro de Estudos, Pesquisa e Atualização em Direito - CEPAD, 1988. Professor convidado da Pontifícia Universidade Católica do Rio Grande do Sul - PUCRS, 1990. Professor convidado da Universidade Federal do Rio Grande do Sul - UFRGS, 1990. Professor de Processo Civil da Escola da Magistratura do Estado do Rio de Janeiro - EMERJ, 1990/2001. Professor de Direito Judiciário Civil da Pontifícia Universidade Católica - PUC/RJ. Nível Graduação, 1982/1997. Chefe do Departamento de Direito Processual da Universidade do Estado do Rio de Janeiro - UERJ, 1998/2003. Diretor de Estudos e Ensino da Escola da Magistratura do Estado do Rio de Janeiro - EMERJ, 2001/2003. Professor convidado da Academia Brasileira de Direito Processual Civil - ABDPC, 2005. Chefe do Departamento de Direito Processual da Universidade do Estado do Rio de Janeiro UERJ, 2006. Professor convidado do Cyrus R. Vance Center for International Justice - New York (EUA).

Em 1982, mediante aprovação em primeiro lugar, ingressou na carreira da Magistratura do Estado do Rio de Janeiro.

Em 2001, foi nomeado Ministro do Superior Tribunal de Justiça.

Em 10 de fevereiro de 2011, foi nomeado Ministro do Supremo Tribunal Federal, pela Presidente Dilma Rousseff, na vaga decorrente da aposentadoria do Ministro Eros Grau, tomando posse em 3 de março do mesmo ano. 


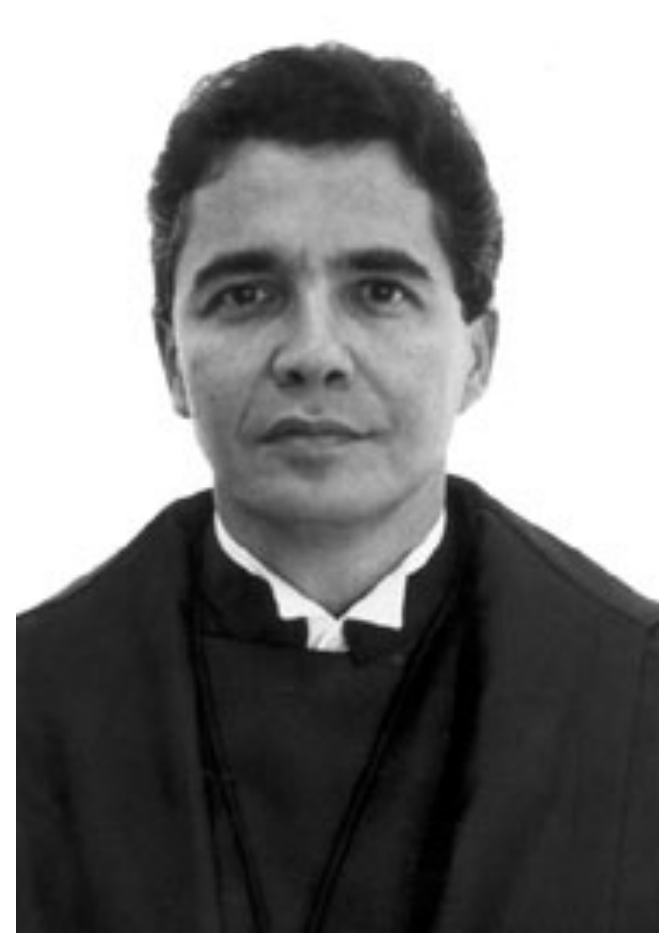

MARCO AURÉLIO MENDES DE FARIAS MELLO nasceu na cidade do Rio de Janeiro, RJ, em 12 de julho de 1946, filho do Dr. Plínio Affonso de Farias Mello e de D. Eunice Mendes de Farias Mello.

Fez os cursos primário e médio no Colégio Souza Marques e o curso científico no Colégio Pedro II, na cidade natal. Bacharelou-se em Ciências Jurídicas e Sociais pela Faculdade de Direito da Universidade Federal do Rio de Janeiro, em 1973. Fez o Mestrado em Direito Privado na mesma Faculdade, obtendo o certificado de capacitação em 1982.

Participou dos seguintes cursos de Extensão e Aperfeiçoamento: Curso Intensivo de Aperfeiçoamento Profissional - Câmara de Comércio dos Países LatinoAmericanos, Rio de Janeiro/RJ, 1969; Curso de Direito do Seguro — Faculdade de Direito da Universidade Federal do Rio de Janeiro, Rio de Janeiro/RJ, 1970; Curso de Disciplina da Navegação Marítima no Brasil — Faculdade de Direito da Universidade Federal do Rio de Janeiro, Rio de Janeiro/RJ, 1973; "Prevenção de Acidentes do Trabalho" - Fundacentro, São Paulo/SP, 1974; Curso de Direito Processual do Trabalho - Instituto dos Advogados do Brasil, Rio de Janeiro/RJ, 1974; Curso de Direito Imobiliário - Editora Sugestões Literárias S/A, São Paulo/SP, 1978; III Ciclo de Estudos sobre Segurança Nacional e Desenvolvimento - Associação dos Diplomados da Escola Superior de Guerra, Rio de Janeiro/RJ, 1978; I Ciclo de Estudos de Normas Internacionais do Trabalho - OIT e Academia Nacional de Direito do Trabalho, tendo sido escolhido orador, Brasília/DF, 1980; Seminário de Direito Judiciário Civil — Faculdade de Direito da Universidade do Rio de Janeiro, Rio de Janeiro/RJ, 1980; Seminário de Atualização em Processo de Execução Escola Superior da Magistratura Nacional e Associação dos Magistrados Brasileiros, 
em convênio com a Universidade do Estado do Rio de Janeiro, Rio de Janeiro/RJ, 1980; Seminário Internacional sobre Negociação e Relações de Trabalho Confederação Nacional da Indústria e pelo Instituto Euvaldo Lodi, Rio de Janeiro/RJ, 1981; Curso Superior de Guerra - Escola Superior de Guerra, Rio de Janeiro/RJ, 1983; Curso In Collective Bargaining in the United States - University of Wiscosin, Madison (EEUU), 1984.

Estagiou no Gabinete do então MM. Dr. Juiz Ederson Mello Serra, titular da $11^{\text {a }}$ Vara Cível do Estado da Guanabara, depois Desembargador do Tribunal de Justiça do Estado do Rio de Janeiro; no escritório de advocacia Professor Joaquim Gomes de Norões e Souza e Carlos Figueiredo Forbes; na Procuradoria-Geral da Justiça do Estado do Rio de Janeiro, tendo prestado assistência judiciária junto a Varas de Órfãos e Sucessões e Varas Criminais; na Assessoria Jurídica do então Banco de Minas Gerais; no Serviço Jurídico do Sindicato dos Representantes Comerciais, no Rio de Janeiro; no Serviço Jurídico da Federação dos Agentes Autônomos do Comércio da Guanabara; no Serviço Jurídico do Conselho Federal dos Representantes Comerciais, no Rio de Janeiro; no Serviço Jurídico do Conselho Regional dos Representantes Comerciais, no Estado do Rio de Janeiro.

Advogou no foro do Estado do Rio de Janeiro, chefiou o Departamento de Assistência Jurídica e Judiciária do Conselho Federal dos Representantes Comerciais e o Departamento de Assistência Jurídica e Judiciária do Conselho Regional dos Representantes Comerciais no Estado do Rio de Janeiro, sendo também advogado da Federação dos Agentes Autônomos do Comércio do Antigo Estado da Guanabara.

Integrou o Ministério Público junto à Justiça do Trabalho da Primeira Região, no período de 1975 a 1978.

Ingressando na Magistratura, foi Juiz Togado do Tribunal Regional do Trabalho da Primeira Região, no período de 1978 a 1981, quando presidiu a Segunda Turma, no biênio 1979/1980.

Foi Ministro Togado do Tribunal Superior do Trabalho, no período de setembro de 1981 a junho de 1990, havendo sido Corregedor-Geral da Justiça do Trabalho, no 
período de dezembro de 1988 a junho de 1990; Presidente da Primeira Turma, no biênio 1985/1986, reeleito para o biênio 1987/1988; Membro do Conselho da Ordem do Mérito Judiciário do Trabalho; Membro da Comissão encarregada das comemorações do Centenário de Nascimento do Ministro Lindolfo Collor.

Nomeado Ministro do Supremo Tribunal Federal, por decreto de 28 de maio de 1990, para a vaga decorrente da aposentadoria do Ministro Carlos Madeira, tomou posse em 13 de junho de 1990.

\section{Gilmar Ferreira Mendes}

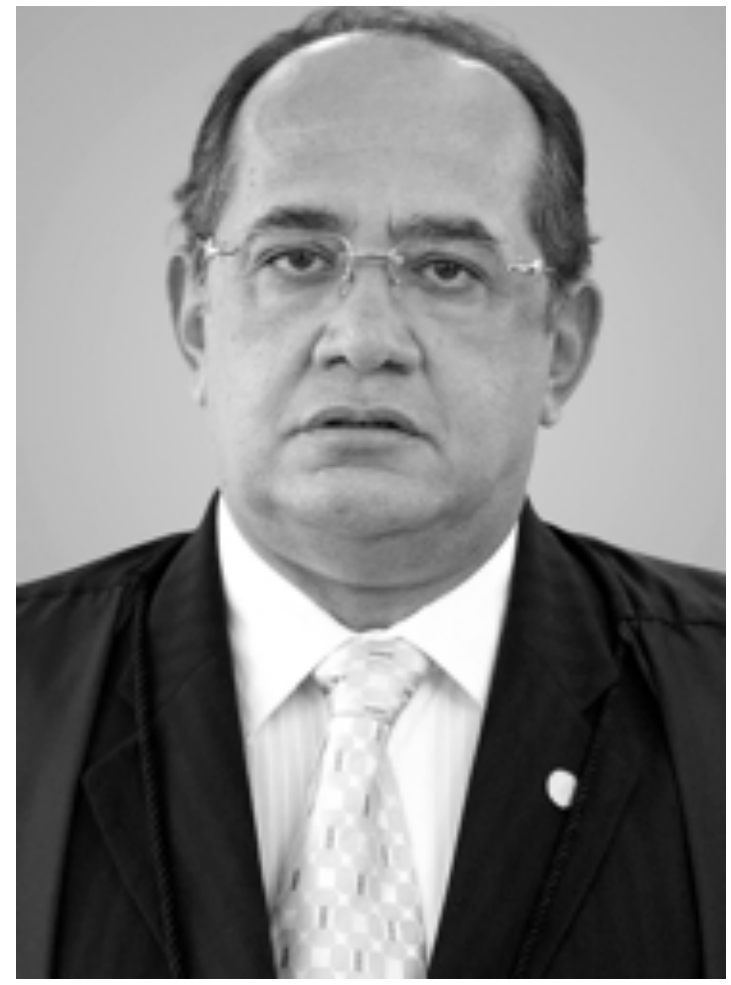

GILMAR FERREIRA MENDES nasceu na cidade de Diamantino, MT, em 30 de dezembro de 1955, filho de Francisco Ferreira Mendes e de Nilde Alves Mendes.

Bacharelou-se em Direito pela Universidade de Brasília em 1978. Fez o Mestrado em Direito e Estado na mesma Universidade, obtendo o certificado de conclusão em 1987, com distinção. Concluiu o Curso de Mestrado pela Westfälische Wilhelms Universität zu Münster, RFA (Magister Legum - L.L.M.), com a dissertação

"Die Zulässigkeitsvoraussetzungen der abstrakten Normenkontrolle vor dem Bundesverfassungsgericht" (Pressupostos de admissibilidade do Controle Abstrato de Normas perante a Corte Constitucional Alemã), desenvolvido sob a orientação do Professor Hans-Uwe Erichsen, Reitor da Universidade de Münster-RFA - 1988 e 1989. Concluiu o curso de Doutorado pela Westfälische Wilhelms - Universität zu Münster, RFA, com a tese "Die abstrakte Normenkotrolle vor dem 
Bundesverfassungsgericht und vor dem brasilianischen Supremo Tribunal Federal" -O Controle abstrato de normas perante a Corte Constitucional Alemã e perante o Supremo Tribunal Federal - (400 p.), desenvolvida sob a orientação do Professor Hans-Uwe Erichsen, Reitor da Universidade de Münster - RFA. Foi aprovado com o predicado Magna cum laudae - novembro de 1990.

Exerceu na Administração Pública os cargos de Procurador da República com atuação em processos do Supremo Tribunal Federal (outubro de 1985 a março de 1988). Foi Adjunto da Subsecretaria-Geral da Presidência da República (1990 e 1991) e Consultor-Jurídico da Secretaria-Geral da Presidência da República (1991 e 1992). Desempenhou a função de Assessor Técnico na Relatoria da Revisão Constitucional na Câmara dos Deputados (dezembro de 1993 a junho de 1994), tendo sido responsável pela elaboração de inúmeros estudos e pareceres. Foi Assessor Técnico no Ministério da Justiça, na gestão do Ministro Nelson Jobim (1995 e 1996), período no qual colaborou na coordenação e na elaboração de projetos de reforma constitucional e legislativa. Foi Subchefe para Assuntos Jurídicos da Casa Civil, de 1996 a janeiro de 2000, e Advogado-Geral da União, de janeiro de 2000 a junho de 2002.

Foi nomeado Ministro do Supremo Tribunal Federal, por decreto de 27 de maio de 2002, decorrente da aposentadoria do Ministro Néri da Silveira, havendo tomado posse em 20 de junho de 2002. 
Joaquim Benedito Barbosa Gomes

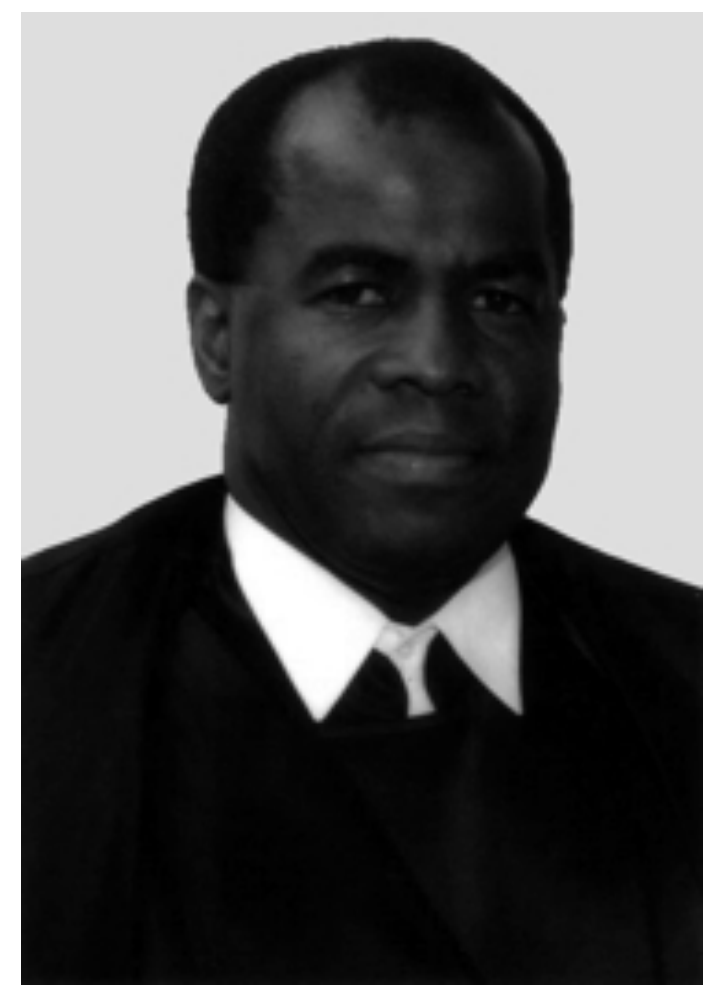

Antes de sua nomeação para o Supremo Tribunal Federal, o Ministro Joaquim Barbosa exerceu vários cargos na Administração Pública Federal. Foi membro do Ministério Público Federal de 1984 a 2003, com atuação em Brasília (1984-1993) e no Rio de Janeiro (19932003); foi Chefe da Consultoria Jurídica do Ministério da Saúde (1985-88); foi Advogado do Serviço Federal de Processamento de Dados-SERPRO (1979-84); foi Oficial de Chancelaria do Ministério das Relações Exteriores (1976-1979), tendo servido na Embaixada do Brasil em Helsinki, Finlândia; foi compositor gráfico do Centro Gráfico do Senado Federal.

Paralelamente ao exercício de cargos no serviço público, manteve estreitas ligações com o mundo acadêmico. É Doutor e Mestre em Direito Público pela Universidade de Paris-II (Panthéon-Assas), onde cumpriu extenso programa de doutoramento de 1988 a 1992, o qual resultou na obtenção de três diplomas de pós-graduação. Cumpriu também o programa de Mestrado em Direito e Estado da Universidade de Brasília (1980-82), que lhe valeu o diploma de Especialista em Direito e Estado por essa Universidade.

É Professor licenciado da Faculdade de Direito da Universidade do Estado do Rio de Janeiro (UERJ), onde ensinou as disciplinas de Direito Constitucional e Direito Administrativo. Foi Visiting Scholar (1999-2000) no Human Rights Institute da Columbia University School of Law, New York, e na University of California Los Angeles School of Law (2002-2003). 
É assíduo conferencista, tanto no Brasil quanto no exterior. Foi bolsista do CNPq (1988-92), da Ford Foundation (1999-2000) e da Fundação Fullbright (2002-2003).

É autor das obras "La Cour Suprême dans le Système Politique Brésilien", publicada na França em 1994 pela Librairie Générale de Droit et de Jurisprudence (LGDJ), na coleção "Bibliothèque Constitutionnelle et de Science Politique"; "Ação Afirmativa \& Princípio Constitucional da Igualdade. O Direito como Instrumento de Transformação Social. A Experiência dos EUA", publicado pela Editora Renovar, Rio de Janeiro, 2001; e de inúmeros artigos de doutrina.

Nasceu em Paracatu, MG, onde fez os estudos primários no Grupo Escolar Dom Serafim Gomes Jardim e no Colégio Estadual Antonio Carlos. Cursou o segundo grau no Colégio Elefante Branco, de Brasília. Fez também estudos complementares de línguas estrangeiras no Brasil, na Inglaterra, nos Estados Unidos, na Áustria e na Alemanha.

\section{Carlos Augusto Ayres de Freitas Britto}

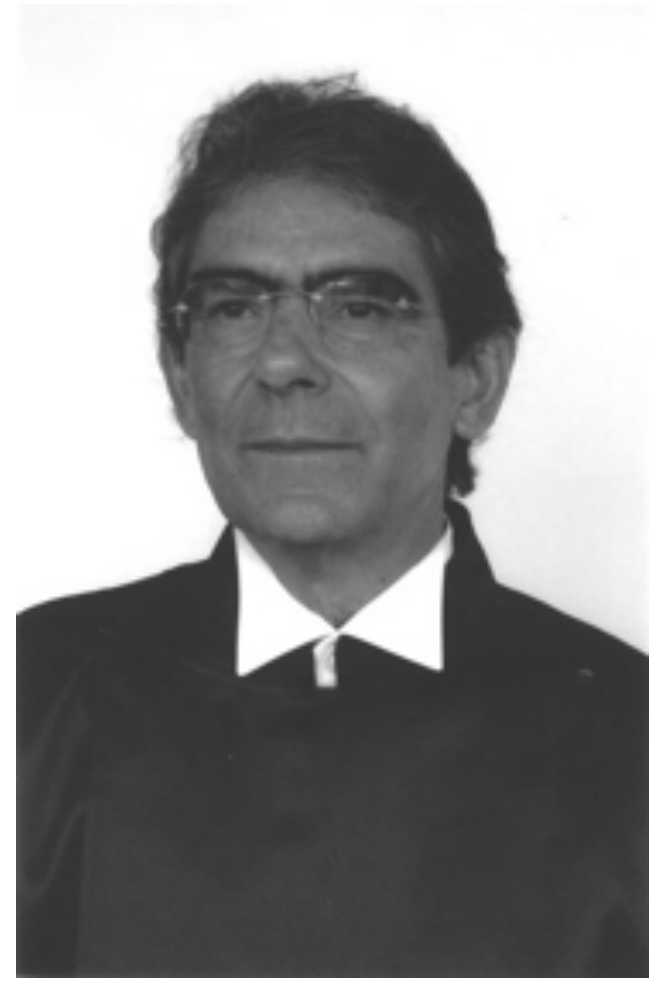

CARLOS AUGUSTO AYRES DE FREITAS BRITTO nasceu em 18 de novembro de 1942, na cidade de Propriá, Estado de Sergipe, filho de João Fernandes de Britto e D. Dalva Ayres de Freitas Britto. É casado com D. Rita de Cássia Pinheiro Reis de Britto e tem cinco filhos: Marcel de Castro Britto, Adriana de Castro Britto, Adriele Pinheiro Reis Ayres de Britto, Tainan Pinheiro Reis Ayres de Britto e Nara Pinheiro Reis Ayres de Britto.

Ingressou na Faculdade de Direito da Universidade Federal de Sergipe em 1962, 
obtendo o diploma de Bacharel em 1966. A partir de 1967, passou a militar na advocacia.

Realizou os cursos de pós-graduação em Aperfeiçoamento em Direito Público e Privado pela Faculdade de Direito de Sergipe (1974/1975); de Mestrado em Direito do Estado (1981/1982) pela Pontifícia Universidade Católica de São Paulo - PUCSP, e de Doutorado em Direito Constitucional (1998) por essa mesma Universidade.

Em Sergipe exerceu os cargos de Consultor-Geral do Estado, de 15-3-1975 a 15-31979; de Procurador- Geral de Justiça, de 15-3-1983 a 27-4-1984; de Procurador do Tribunal de Contas, de 1978 a 1990; e de Chefe do Departamento Jurídico do Conselho de Desenvolvimento Econômico do Estado - CONDESE, de 1970 a 1978.

Foi nomeado Ministro do Supremo Tribunal Federal pelo Presidente da República Luiz Inácio Lula da Silva, por decreto de 5 de junho de 2003, na vaga decorrente da aposentadoria do Ministro Ilmar Galvão, havendo tomado posse em 25 do mesmo mês. Aposentou-se por Decreto de 14 de novembro de 2012, publicado no DOU, Seção 2, p. 2 em 16 de novembro de 2012 sendo homenageado na Sessão Plenária do dia 14 de novembro de 2012.

Foi eleito pelos seus pares na Sessão Plenária de 14 de abril de 2012 para exercer a Presidência do Supremo Tribunal Federal para o biênio de 2012-2014, tendo sido empossado em 19 de abril de 2012. 


\section{Antonio Cezar Peluso}

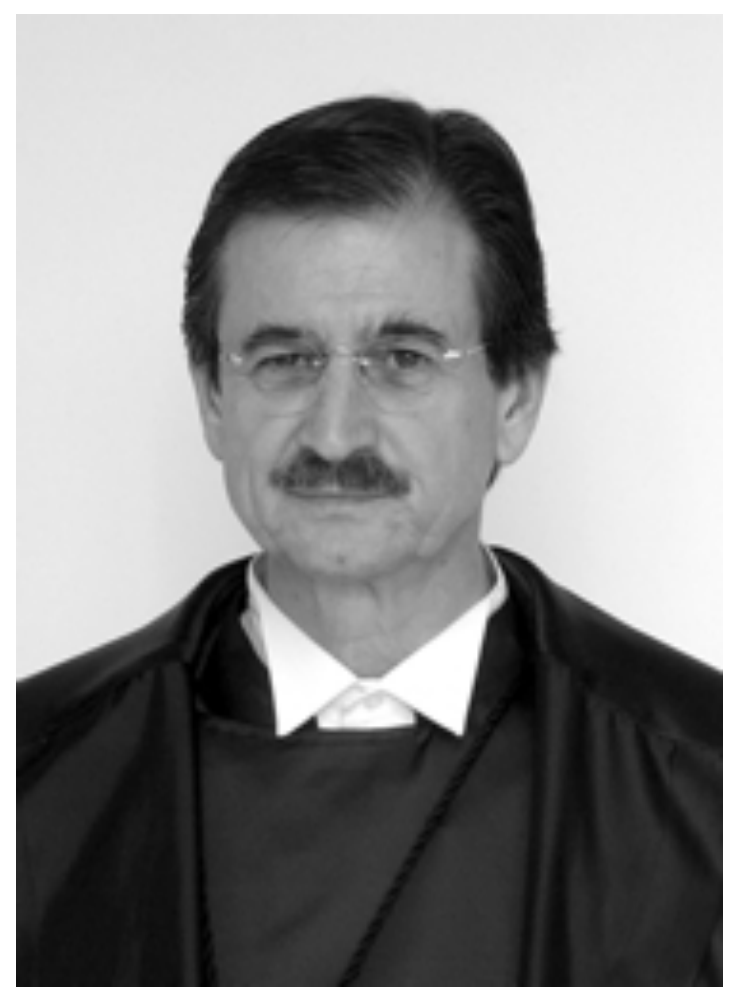

ANTONIO CEZAR PELUSO nasceu em 3 de setembro de 1942, em Bragança Paulista, São Paulo, filho de Daniel Deusdedit Peluso e de D. Maria Apparecida Bueno Peluso.

Fez o Curso Ginasial no Seminário Diocesano São José, em São Vicente (1955-1958), e o Clássico no Colégio Estadual Arnolfo Azevedo, em Lorena, e no Instituto de Educação Canadá, em Santos (1959-1961), todas cidades paulistas.

Foi primeiro classificado no concurso vestibular quando ingressou na Faculdade Católica de Direito de Santos em 1962 e conquistou o diploma de Bacharel em Ciências jurídicas no ano de 1966. Fez jus a registros escolares de Louvor, na cadeira de Direito Constitucional, propostos pelos Professores Olavo de Paula Borges e Carlos de Alvarenga Bernardes, e de Láurea da Turma em todos os anos do curso de Bacharelado.

Fez os cursos de Especialização em Filosofia do Direito sob orientação do Professor Miguel Reale, na Faculdade de Direito da Universidade de São Paulo (1967) e Direito Processual Civil, coordenado pelo Professor José Manuel de Arruda Alvim Neto, na Faculdade Paulista de Direito da PUC de São Paulo, nos períodos de agosto a dezembro dos anos de 1974 e 1975. Realizou os cursos de Pós-Graduação, para o Mestrado em Direito Civil, orientado pelo Professor Sílvio Rodrigues, na Faculdade de Direito da USP, de agosto de 1974 a dezembro de 1975, e sob orientação do Professor Agostinho Neves de Arruda Alvim, na Faculdade Paulista de Direito da Universidade Católica de São Paulo, de agosto de 1973 a dezembro de 1975. Participou do Curso de Doutorado em Direito Processual Civil, sob orientação 
do Professor Alfredo Buzaid, na Faculdade de Direito da USP, de agosto de 1973 a dezembro de 1975.

Obteve o segundo lugar no $135^{\circ}$ Concurso Público de Provas e Títulos para ingresso na Magistratura do Estado de São Paulo em 1967. Exerceu os cargos de Juiz Substituto da $14^{\mathrm{a}}$ Circunscrição Judiciária, sediada em Itapetininga (9-1 a 26-111968), e de Juiz de Direito nas comarcas de São Sebastião, $1^{a}$ entrância, promovido por merecimento (27-11-1968 a 18-2-1970); Igarapava, 2a entrância, mediante promoção por antigüidade (19-2-1970 a $\left.1^{\circ}-8-1972\right)$, sendo promovido por merecimento a $47^{\circ}$ Juiz Substituto da Capital, $3^{\mathrm{a}}$ entrância (2-8-1972 a 15-12-1975).

A 16-12-1975, em virtude de promoção por merecimento, assumiu o cargo de Juiz de Direito da $7^{\mathrm{a}}$ Vara da Família e das Sucessões da Capital, entrância especial, no qual permaneceu até 10-11-1982. No intervalo de $1^{\circ}-1-1978$ a 31-12-1979, convocado pelo Conselho Superior de Magistratura, foi Juiz Auxiliar da Corregedoria-Geral da Justiça.

Ainda pelo critério de merecimento, foi promovido a Juiz do $2^{\circ}$ Tribunal de Alçada Civil, $5^{\text {a }}$ Câmara, exercendo as funções de 11-11-1982 a 13-4-1986.

A 14-4-1986 ascendeu, por merecimento, ao cargo de Desembargador do Tribunal de Justiça de São Paulo, com assento na $2^{\mathrm{a}}$ Câmara de Direito Privado. Integrou, como membro efetivo, o Órgão Especial da referida Corte. Foi indicado, a 26-2-1991, em lista tríplice elaborada pelo Superior Tribunal de Justiça, para o provimento da vaga decorrente da aposentadoria do Ministro Evandro Gueiros Leite.

Coordenou o Curso de Iniciação Funcional dos juízes aprovados no $156^{\circ}$ Concurso de Ingresso na Magistratura, promovido pela Escola Paulista de Magistratura (março de 1991) e foi membro das Comissões Examinadoras do $163^{\circ}$ e do $164^{\circ}$ Concursos de ingresso na magistratura paulista (1993).

Integrou, em 1993, as Comissões designadas pela Presidência do Tribunal de Justiça de São Paulo para estudar alterações nas Leis Complementares estaduais $n^{\circ} 370$, de 
1984 e n 670 , de 1989, e para estudo da viabilidade de projeto de lei dispondo sobre estágio no Poder Judiciário estadual.

Presidiu a Comissão de Concursos para Provimento das Serventias Extrajudiciais do Tribunal de Justiça de São Paulo (1994).

Por eleição do Órgão Especial, foi membro titular da Comissão de Organização Judiciária do Tribunal de Justiça paulista (1994-1998) e da Comissão de Redação (1998-1999).

Ainda por eleição do Órgão Especial do Tribunal de Justiça do Estado de São Paulo, foi Vice-Diretor e Diretor da Escola Paulista de Magistratura nos biênios consecutivos de 1998-1999 e 2000-2001. A partir de março de 2002 assumiu a Diretoria da revista "Diálogos e Debates" da referida instituição.

\section{José Celso de Mello Filho}

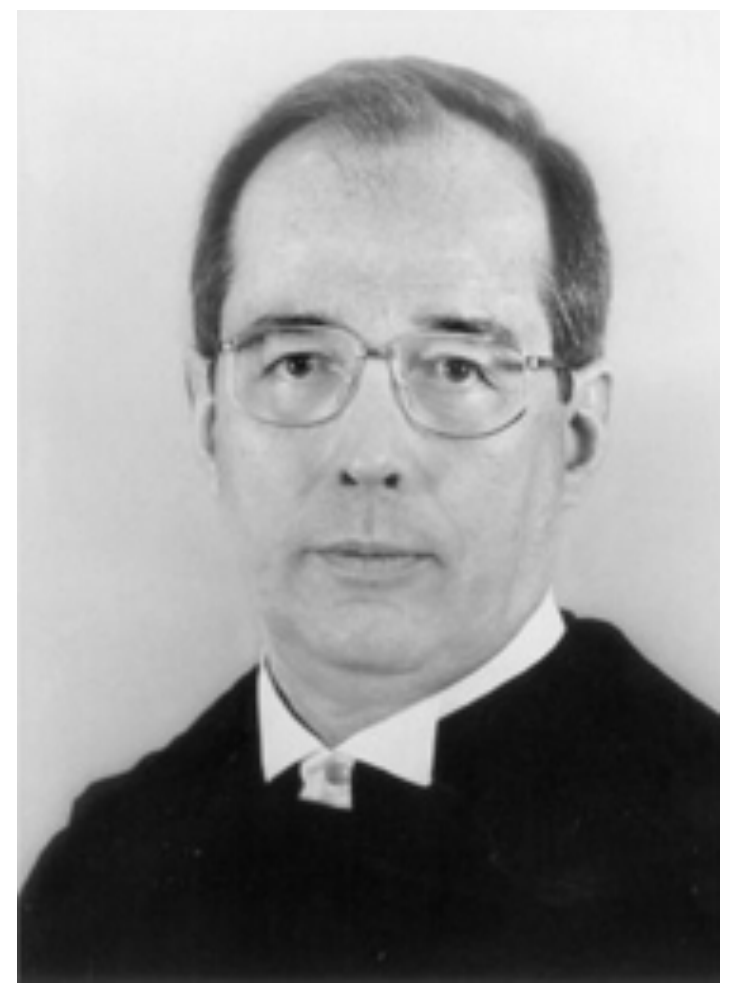

JOSÉ CELSO DE MELLO FILHO, filho do Prof. José Celso de Mello e da Prof. ${ }^{a}$ Maria Zenaide de Almeida Mello, nasceu em Tatuí, Estado de São Paulo, em $1^{\circ}$ de novembro de 1945 . É casado com a Prof. ${ }^{\text {a }}$ Maria de Lourdes Campos de Mello, com quem tem duas filhas: Ana Laura Campos de Mello e Sílvia Renata Campos de Mello.

Fez, em Tatuí/SP, na Escola Modelo e no Instituto de Educação Barão de Suruí, os cursos primário e secundário. Completou o curso colegial nos Estados Unidos da América, onde se 
graduou na Robert E. Lee Senior High School, em Jacksonville, Flórida (1963/1964).

Graduou-se em Ciências Jurídicas e Sociais pela Faculdade de Direito da Universidade de São Paulo, a tradicional Faculdade de Direito do Largo de São Francisco (Turma de 1969), fundada em 11 de agosto de 1827.

Ingressou no Ministério Público do Estado de São Paulo, em 1970, mediante concurso público de provas e títulos no qual foi classificado em primeiro lugar, permanecendo, nessa Instituição, até 1989, quando foi nomeado para o Supremo Tribunal Federal. Exerceu os cargos de Promotor de Justiça e Curador Geral nas Comarcas de Santos, Osasco, São José dos Campos, Cândido Mota, Palmital, Garça e São Paulo. Foi, ainda, Curador Fiscal de Massas Falidas, Curador de Resíduos, Curador Judicial de Ausentes e Incapazes, Curador de Fundações, Curador de Registros Públicos, Curador de Casamentos, Curador de Menores, Curador de Família e Sucessões, Curador de Acidentes do Trabalho e Promotor de Justiça Criminal, inclusive junto ao Tribunal do Júri.

Titular do cargo de Procurador de Justiça no Estado de São Paulo (membro do Ministério Público de $2^{\mathrm{a}}$ instância junto aos Tribunais locais), dele pediu exoneração quando nomeado para o cargo de Juiz do Supremo Tribunal Federal.

Integrou, por três vezes, a lista do quinto constitucional, por decisão do Tribunal de Justiça do Estado de São Paulo e do Conselho Superior da Magistratura (1988 e 1989), para efeito de preenchimento de vaga reservada à classe do Ministério Público nos Tribunais Paulistas .

Foi Secretário Geral da Consultoria-Geral da República (1986/1989). Exerceu o cargo de Consultor-Geral da República, em caráter interino, mediante nomeação presidencial, em diversos períodos, nos anos de 1986, 1987 e 1988.

Foi nomeado Juiz do Supremo Tribunal Federal, mediante ato do Presidente da República (Decreto de 30-6-1989), ocupando vaga decorrente da aposentadoria do Ministro Luiz Rafael Mayer. Tomou posse no cargo em 17 de agosto de 1989. 
Eleito pelo Supremo Tribunal Federal, integrou o Tribunal Superior Eleitoral, como Juiz Substituto, no período de 12 de junho de 1990 a 12 de junho de 1992. 


\section{ANEXO 2}

\section{1 - Exigência da prévia aprovação no exame da OAB para exercício}

da advocacia.

Classe: RE

Número: 603583

Data de Início: 20/11/2009

Data Prevista Fim: 10/12/2009

Relator: MIN. MARCO AURÉLIO

Manifestação/Voto

\begin{tabular}{|c|c|c|c|}
\hline Ministro & $\begin{array}{c}\text { Questão } \\
\text { Constitucional }\end{array}$ & $\begin{array}{c}\text { Repercussão } \\
\text { Geral }\end{array}$ & $\begin{array}{l}\text { Reafirmação de } \\
\text { Jurisprudência }\end{array}$ \\
\hline MIN. MARCO AURÉLIO & Há & Há & - \\
\hline MIN. CELSO DE MELLO & - & Há & - \\
\hline MIN. GILMAR MENDES & - & Há & - \\
\hline MIN. ELLEN GRACIE & - & Há & - \\
\hline MIN. JOAQUIM BARBOSA & - & Há & - \\
\hline MIN. DIAS TOFFOLI & - & Há & - \\
\hline MIN. EROS GRAU & - & Há & - \\
\hline MIN. CEZAR PELUSO & - & Há & - \\
\hline MIN. RICARDO LEWANDOWSKI & - & Há & - \\
\hline MIN. AYRES BRITTO & - & - & - \\
\hline MIN. CÁRMEN LÚCIA & - & - & - \\
\hline
\end{tabular}




\section{ANEXO 3}

\section{ADPF 186 - ARGÜIÇÃO DE DESCUMPRIMENTO DE PRECEITO FUNDAMENTAL (Processo físico)}

\begin{tabular}{|c|c|c|c|c|}
\hline Guia & Origem & Destino & $\begin{array}{c}\text { Data de } \\
\text { Remessa }\end{array}$ & $\begin{array}{c}\text { Data de } \\
\text { Recebimento }\end{array}$ \\
\hline $194 / 2010$ & $\begin{array}{l}\text { GABINETE MINISTRO } \\
\text { RICARDO } \\
\text { LEWANDOWSKI }\end{array}$ & $\begin{array}{l}\text { SEÇÃO DE PROCESSOS } \\
\text { DO CONTROLE } \\
\text { CONCENTRADO }\end{array}$ & $17 / 02 / 2010$ & $17 / 02 / 2010$ \\
\hline $147 / 2010$ & $\begin{array}{l}\text { SEÇÃO DE PROCESSOS } \\
\text { DO CONTROLE } \\
\text { CONCENTRADO }\end{array}$ & $\begin{array}{l}\text { GABINETE MINISTRO } \\
\text { RICARDO } \\
\text { LEWANDOWSKI }\end{array}$ & $11 / 02 / 2010$ & $11 / 02 / 2010$ \\
\hline $168 / 2010$ & $\begin{array}{l}\text { GABINETE MINISTRO } \\
\text { RICARDO } \\
\text { LEWANDOWSKI }\end{array}$ & $\begin{array}{l}\text { SEÇÃO DE PROCESSOS } \\
\text { DO CONTROLE } \\
\text { CONCENTRADO }\end{array}$ & $11 / 02 / 2010$ & $11 / 02 / 2010$ \\
\hline $1661 / 2009$ & $\begin{array}{l}\text { SEÇÃO DE PROCESSOS } \\
\text { DO CONTROLE } \\
\text { CONCENTRADO }\end{array}$ & $\begin{array}{l}\text { GABINETE MINISTRO } \\
\text { RICARDO } \\
\text { LEWANDOWSKI }\end{array}$ & $04 / 12 / 2009$ & $04 / 12 / 2009$ \\
\hline $2352 / 2009$ & $\begin{array}{l}\text { GABINETE MINISTRO } \\
\text { RICARDO } \\
\text { LEWANDOWSKI }\end{array}$ & $\begin{array}{l}\text { SEÇÃO DE PROCESSOS } \\
\text { DO CONTROLE } \\
\text { CONCENTRADO }\end{array}$ & $02 / 12 / 2009$ & $03 / 12 / 2009$ \\
\hline $1600 / 2009$ & $\begin{array}{l}\text { SEÇÃO DE PROCESSOS } \\
\text { DO CONTROLE } \\
\text { CONCENTRADO }\end{array}$ & $\begin{array}{l}\text { GABINETE MINISTRO } \\
\text { RICARDO } \\
\text { LEWANDOWSKI }\end{array}$ & $24 / 11 / 2009$ & $24 / 11 / 2009$ \\
\hline $2259 / 2009$ & $\begin{array}{l}\text { GABINETE MINISTRO } \\
\text { RICARDO } \\
\text { LEWANDOWSKI }\end{array}$ & $\begin{array}{l}\text { SEÇÃO DE PROCESSOS } \\
\text { DO CONTROLE } \\
\text { CONCENTRADO }\end{array}$ & $23 / 11 / 2009$ & $24 / 11 / 2009$ \\
\hline $1487 / 2009$ & $\begin{array}{l}\text { SEÇÃO DE PROCESSOS } \\
\text { DO CONTROLE } \\
\text { CONCENTRADO }\end{array}$ & $\begin{array}{l}\text { GABINETE MINISTRO } \\
\text { RICARDO } \\
\text { LEWANDOWSKI }\end{array}$ & $06 / 11 / 2009$ & $06 / 11 / 2009$ \\
\hline $2124 / 2009$ & $\begin{array}{l}\text { GABINETE MINISTRO } \\
\text { RICARDO } \\
\text { LEWANDOWSKI }\end{array}$ & $\begin{array}{l}\text { SEÇÃO DE PROCESSOS } \\
\text { DO CONTROLE } \\
\text { CONCENTRADO }\end{array}$ & $04 / 11 / 2009$ & $04 / 11 / 2009$ \\
\hline $1456 / 2009$ & $\begin{array}{l}\text { SEÇÃO DE PROCESSOS } \\
\text { DO CONTROLE }\end{array}$ & $\begin{array}{l}\text { GABINETE MINISTRO } \\
\text { RICARDO }\end{array}$ & $29 / 10 / 2009$ & $29 / 10 / 2009$ \\
\hline
\end{tabular}




\begin{tabular}{|c|c|c|c|c|}
\hline & CONCENTRADO & LEWANDOWSKI & & \\
\hline $2083 / 2009$ & $\begin{array}{l}\text { GABINETE MINISTRO } \\
\text { RICARDO } \\
\text { LEWANDOWSKI }\end{array}$ & $\begin{array}{l}\text { SEÇÃO DE PROCESSOS } \\
\text { DO CONTROLE } \\
\text { CONCENTRADO }\end{array}$ & $28 / 10 / 2009$ & $28 / 10 / 2009$ \\
\hline $1450 / 2009$ & $\begin{array}{l}\text { SEÇÃO DE PROCESSOS } \\
\text { DO CONTROLE } \\
\text { CONCENTRADO }\end{array}$ & $\begin{array}{l}\text { GABINETE MINISTRO } \\
\text { RICARDO } \\
\text { LEWANDOWSKI }\end{array}$ & $28 / 10 / 2009$ & $28 / 10 / 2009$ \\
\hline $2072 / 2009$ & $\begin{array}{l}\text { GABINETE MINISTRO } \\
\text { RICARDO } \\
\text { LEWANDOWSKI }\end{array}$ & $\begin{array}{l}\text { SEÇÃO DE PROCESSOS } \\
\text { DO CONTROLE } \\
\text { CONCENTRADO }\end{array}$ & $27 / 10 / 2009$ & $28 / 10 / 2009$ \\
\hline $1415 / 2009$ & $\begin{array}{l}\text { SEÇÃO DE PROCESSOS } \\
\text { DO CONTROLE } \\
\text { CONCENTRADO }\end{array}$ & $\begin{array}{l}\text { GABINETE MINISTRO } \\
\text { RICARDO } \\
\text { LEWANDOWSKI }\end{array}$ & $22 / 10 / 2009$ & $22 / 10 / 2009$ \\
\hline $2011 / 2009$ & $\begin{array}{l}\text { GABINETE MINISTRO } \\
\text { RICARDO } \\
\text { LEWANDOWSKI }\end{array}$ & $\begin{array}{l}\text { SEÇÃO DE PROCESSOS } \\
\text { DO CONTROLE } \\
\text { CONCENTRADO }\end{array}$ & $20 / 10 / 2009$ & $20 / 10 / 2009$ \\
\hline $1316 / 2009$ & $\begin{array}{l}\text { SEÇÃO DE PROCESSOS } \\
\text { DO CONTROLE } \\
\text { CONCENTRADO }\end{array}$ & $\begin{array}{l}\text { GABINETE MINISTRO } \\
\text { RICARDO } \\
\text { LEWANDOWSKI }\end{array}$ & $06 / 10 / 2009$ & $06 / 10 / 2009$ \\
\hline $2897 / 2009$ & SEÇÃO DE EXPEDIÇÃO & $\begin{array}{l}\text { SEÇÃO DE PROCESSOS } \\
\text { DO CONTROLE } \\
\text { CONCENTRADO }\end{array}$ & $02 / 10 / 2009$ & $02 / 10 / 2009$ \\
\hline $4052 / 2009$ & $\begin{array}{l}\text { GABINETE DO } \\
\text { SECRETÁRIO-SEJ }\end{array}$ & SEÇÃO DE EXPEDIÇÃO & $30 / 09 / 2009$ & $30 / 09 / 2009$ \\
\hline $1812 / 2009$ & $\begin{array}{l}\text { GABINETE MINISTRO } \\
\text { RICARDO } \\
\text { LEWANDOWSKI }\end{array}$ & $\begin{array}{l}\text { GABINETE DO } \\
\text { SECRETÁRIO-SEJ }\end{array}$ & $30 / 09 / 2009$ & $30 / 09 / 2009$ \\
\hline $3989 / 2009$ & $\begin{array}{l}\text { GABINETE DO } \\
\text { SECRETÁRIO-SEJ }\end{array}$ & $\begin{array}{l}\text { GABINETE MINISTRO } \\
\text { RICARDO } \\
\text { LEWANDOWSKI }\end{array}$ & $28 / 09 / 2009$ & $28 / 09 / 2009$ \\
\hline $3747 / 2009$ & $\begin{array}{l}\text { SEÇÃO DE } \\
\text { COMUNICAÇÕES }\end{array}$ & $\begin{array}{l}\text { GABINETE DO } \\
\text { SECRETÁRIO-SEJ }\end{array}$ & $28 / 09 / 2009$ & $28 / 09 / 2009$ \\
\hline $1225 / 2009$ & $\begin{array}{l}\text { SEÇÃO DE PROCESSOS } \\
\text { DO CONTROLE } \\
\text { CONCENTRADO }\end{array}$ & $\begin{array}{l}\text { SEÇÃO DE } \\
\text { COMUNICAÇÕES }\end{array}$ & 18/09/2009 & $18 / 09 / 2009$ \\
\hline $1714 / 2009$ & $\begin{array}{l}\text { GABINETE MINISTRO } \\
\text { RICARDO }\end{array}$ & $\begin{array}{l}\text { SEÇÃO DE PROCESSOS } \\
\text { DO CONTROLE }\end{array}$ & $16 / 09 / 2009$ & $16 / 09 / 2009$ \\
\hline
\end{tabular}




\begin{tabular}{|c|c|c|c|c|}
\hline & LEWANDOWSKI & CONCENTRADO & & \\
\hline $950 / 2009$ & $\begin{array}{l}\text { SEÇÃO DE PROCESSOS } \\
\text { DO CONTROLE } \\
\text { CONCENTRADO }\end{array}$ & $\begin{array}{l}\text { GABINETE MINISTRO } \\
\text { RICARDO } \\
\text { LEWANDOWSKI }\end{array}$ & $17 / 08 / 2009$ & $17 / 08 / 2009$ \\
\hline $2241 / 2009$ & SEÇÃO DE EXPEDIÇÃO & $\begin{array}{l}\text { SEÇÃO DE PROCESSOS } \\
\text { DO CONTROLE } \\
\text { CONCENTRADO }\end{array}$ & $07 / 08 / 2009$ & $07 / 08 / 2009$ \\
\hline $3206 / 2009$ & $\begin{array}{l}\text { GABINETE DO } \\
\text { SECRETÁRIO-SEJ }\end{array}$ & SEÇÃO DE EXPEDIÇÃO & $06 / 08 / 2009$ & $07 / 08 / 2009$ \\
\hline $2642 / 2009$ & $\begin{array}{l}\text { SEÇÃO DE } \\
\text { COMUNICAÇÕES }\end{array}$ & $\begin{array}{l}\text { GABINETE DO } \\
\text { SECRETÁRIO-SEJ }\end{array}$ & $06 / 08 / 2009$ & $06 / 08 / 2009$ \\
\hline $852 / 2009$ & $\begin{array}{l}\text { SEÇÃO DE PROCESSOS } \\
\text { DO CONTROLE } \\
\text { CONCENTRADO }\end{array}$ & $\begin{array}{l}\text { SEÇÃO DE } \\
\text { COMUNICAÇÕES }\end{array}$ & $05 / 08 / 2009$ & $05 / 08 / 2009$ \\
\hline $8435 / 2009$ & $\begin{array}{l}\text { SEÇÃO DE } \\
\text { PREVENÇÃO E } \\
\text { DISTRIBUIÇÃO }\end{array}$ & $\begin{array}{l}\text { SEÇÃO DE PROCESSOS } \\
\text { DO CONTROLE } \\
\text { CONCENTRADO }\end{array}$ & $04 / 08 / 2009$ & $04 / 08 / 2009$ \\
\hline $842 / 2009$ & $\begin{array}{l}\text { SEÇÃO DE PROCESSOS } \\
\text { DO CONTROLE } \\
\text { CONCENTRADO }\end{array}$ & $\begin{array}{l}\text { SEÇÃO DE } \\
\text { PREVENÇÃO E } \\
\text { DISTRIBUIÇÃO }\end{array}$ & 03/08/2009 & $03 / 08 / 2009$ \\
\hline $1428 / 2009$ & PRESIDÊNCIA & $\begin{array}{l}\text { SEÇÃO DE PROCESSOS } \\
\text { DO CONTROLE } \\
\text { CONCENTRADO }\end{array}$ & $03 / 08 / 2009$ & $03 / 08 / 2009$ \\
\hline $815 / 2009$ & $\begin{array}{l}\text { SEÇÃO DE PROCESSOS } \\
\text { DO CONTROLE } \\
\text { CONCENTRADO }\end{array}$ & PRESIDÊNCIA & $28 / 07 / 2009$ & $28 / 07 / 2009$ \\
\hline $1355 / 2009$ & PRESIDÊNCIA & $\begin{array}{l}\text { SEÇÃO DE PROCESSOS } \\
\text { DO CONTROLE } \\
\text { CONCENTRADO }\end{array}$ & $27 / 07 / 2009$ & $27 / 07 / 2009$ \\
\hline $794 / 2009$ & $\begin{array}{l}\text { SEÇÃO DE PROCESSOS } \\
\text { DO CONTROLE } \\
\text { CONCENTRADO }\end{array}$ & PRESIDÊNCIA & $24 / 07 / 2009$ & $24 / 07 / 2009$ \\
\hline $2125 / 2009$ & SEÇÃO DE EXPEDIÇÃO & $\begin{array}{l}\text { SEÇÃO DE PROCESSOS } \\
\text { DO CONTROLE } \\
\text { CONCENTRADO }\end{array}$ & $23 / 07 / 2009$ & $23 / 07 / 2009$ \\
\hline $2970 / 2009$ & $\begin{array}{l}\text { GABINETE DO } \\
\text { SECRETÁRIO-SEJ }\end{array}$ & SEÇÃO DE EXPEDIÇÃO & $22 / 07 / 2009$ & $22 / 07 / 2009$ \\
\hline
\end{tabular}




\begin{tabular}{|c|c|c|c|c|}
\hline $1317 / 2009$ & PRESIDÊNCIA & $\begin{array}{l}\text { GABINETE DO } \\
\text { SECRETÁRIO-SEJ }\end{array}$ & $22 / 07 / 2009$ & $22 / 07 / 2009$ \\
\hline $2447 / 2009$ & $\begin{array}{l}\text { SEÇÃO DE } \\
\text { COMUNICAÇÕES }\end{array}$ & PRESIDÊNCIA & $22 / 07 / 2009$ & $22 / 07 / 2009$ \\
\hline $2964 / 2009$ & $\begin{array}{l}\text { GABINETE DO } \\
\text { SECRETÁRIO-SEJ }\end{array}$ & $\begin{array}{l}\text { SEÇÃO DE } \\
\text { COMUNICAÇÕES }\end{array}$ & $21 / 07 / 2009$ & $21 / 07 / 2009$ \\
\hline $1306 / 2009$ & PRESIDÊNCIA & $\begin{array}{l}\text { GABINETE DO } \\
\text { SECRETÁRIO-SEJ }\end{array}$ & $21 / 07 / 2009$ & $21 / 07 / 2009$ \\
\hline $762 / 2009$ & $\begin{array}{l}\text { SEÇÃO DE PROCESSOS } \\
\text { DO CONTROLE } \\
\text { CONCENTRADO }\end{array}$ & PRESIDÊNCIA & $20 / 07 / 2009$ & $20 / 07 / 2009$ \\
\hline $7735 / 2009$ & $\begin{array}{l}\text { SEÇÃO DE } \\
\text { PREVENÇÃO E } \\
\text { DISTRIBUIÇÃO }\end{array}$ & $\begin{array}{l}\text { SEÇÃO DE PROCESSOS } \\
\text { DO CONTROLE } \\
\text { CONCENTRADO }\end{array}$ & $20 / 07 / 2009$ & $20 / 07 / 2009$ \\
\hline
\end{tabular}

